\title{
Geology of the Western
}

Great Smoky Mountains

\section{Tennessee}

GEOLOGICAL SURVEY PROFESSIONAL PAPER 349-D

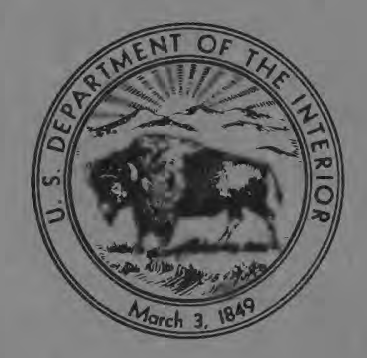




\section{Geology of the}

Great Smoky Mountains

\section{Tennessee and North}

Carolina

GEOLOGICAL SURVEY PROFESIONAL PAPER 349

This volume was published

in separate chapters, $A-D$

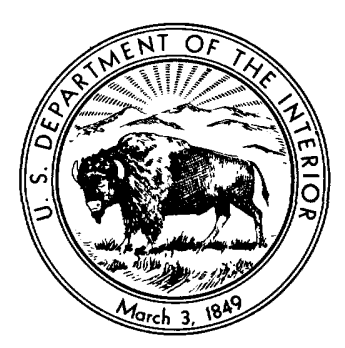




\section{Geology of the Western \\ Great Smoky Mountains}

\section{Tennessee}

By ROBERT B. NEUMAN and WILLIS H. NELSON

GEOLOGY OF THE GREAT SMOKY MOUNTAINS, TENNESSEE AND NORTH CAROLINA

GEOLOGICAL SURVEY PROFESIONAL PAPER 349-D

Interpretation of geologic history from late Precambrian on, based on mapping in and around the western part of the Great Smoky Mountains National Park

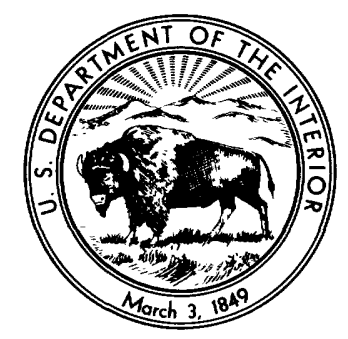

UNITED STATES GOVERNMENT PRINTING OFFICE, WASHINGTON : 1965 


\section{UNITED STATES DEPARTMENT OF THE INTERIOR \\ STEWART L. UDALL, Secretary \\ GEOLOGIGAL SURVEY \\ Thomas B. Nolan, Director}




\section{CONTENTS}

Abstract

Introduction.

Location

Geography

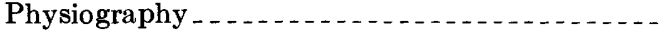

Human geography ..........................

Fieldwork

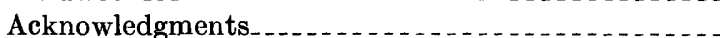

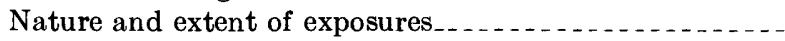

Structural framework . . . . . . . . . . . . . . . . . . . .

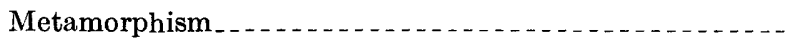

Later Precambrian rocks.

Ocoee Series

Great Smoky Group . . .

Elkmont Sandstone ..................

Snowbird Group..... Metcalf Phyllite.......................

Unclassified formation of Ocoee Series....... Cades Sandstone.....

Walden Creek Group.................

Licklog(?) Formation

Wilhite Formation

Sandsuck Formation . . .

Cambrian and Cambrian(?) rocks. . . . . . . . . . .

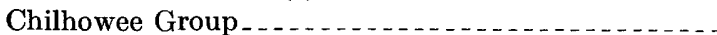

Cochran Formation

Nichols Shale....

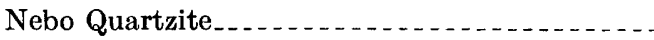

Murray Shale ...........................

Hesse Quartzite . . . . . . . . . . . . . . .

Helenmode Formation

Age of the Chilhowee Group . . . . . . . .

Shady Dolomite.......

Rome Formation.

Missing interval

Ordovician System

Lower Ordovician Series. ....................

Knox Group-Jonesboro Limestone.......

Middle Ordovician Series...........

Lenoir Limestone.

Blockhouse Shale..............

Tellico Formation

Chota Formation. . . . . . .

Sevier Formation . . .

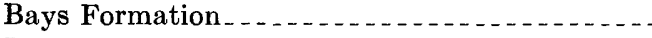

Tellico Formation and Blockhouse Shale, undifferentiated .........................

Correlation of Middle Ordovician Series......

\begin{tabular}{|c|c|}
\hline age & \\
\hline D1 & Devonian System \\
\hline 2 & Upper Devonian Series. \\
\hline 2 & Chattanooga Shale \\
\hline 3 & Mississippian System \\
\hline 3 & Lower Mississippian Series \\
\hline 3 & Grainger Formation \\
\hline 4 & Upper Mississippian Series. \\
\hline 4 & Greasy Cove Formation \\
\hline 4 & $\begin{array}{l}\text { Greasy Cove and Grainger Formations, undiffer- } \\
\text { entiated }\end{array}$ \\
\hline 5 & Structural geology \\
\hline $\begin{array}{l}5 \\
5\end{array}$ & Rocks beneath Great Smoky fault \\
\hline 6 & Syncline north of Chilhowee Mountain \\
\hline 7 & Guess Creek fault \\
\hline 9 & $\begin{array}{l}\text { Rocks between Guess Creek and Great Smoky } \\
\text { faults }\end{array}$ \\
\hline 10 & Overridden rocks of the windows \\
\hline 10 & Great Smoky fault \\
\hline 14 & Chilhowee Mountain structural block \\
\hline 14 & Miller Cove fault \\
\hline 14 & Rocks between Miller Cove and Rabbit Creek faults \\
\hline 22 & Rabbit Creek fault \\
\hline 23 & Rocks between Rabbit Creek and Oconaluftee faults. \\
\hline 23 & Oconaluftee fault \\
\hline 25 & Rocks above Oconaluftee fault \\
\hline 26 & Interpretive summary \\
\hline 27 & Reconstruction of Ocoee basin of sedimentation \\
\hline 27 & Sedimentation of Ocoee Series \\
\hline 28 & Elkmont and Cades Sandstones. \\
\hline 29 & Metcalf Phyllite \\
\hline 29 & Wilhite Formation \\
\hline 32 & - \\
\hline $\begin{array}{l}33 \\
33\end{array}$ & Later Paleozoic time \\
\hline 33 & Time of folding, metamorphism, and faulting \\
\hline 33 & Surficial geology and post-Paleozoic history \\
\hline 34 & re province \\
\hline 35 & Outliers of the Valley and Ridge province- the coves_. \\
\hline 35 & Tuckaleechee Cove \\
\hline 36 & Cades Cove \\
\hline 37 & Miller Cove. \\
\hline $\begin{array}{l}38 \\
38\end{array}$ & Blue Ridge province \\
\hline & Post-Paleozoic history \\
\hline & eferences cited \\
\hline 4 & \\
\hline
\end{tabular}




\section{ILLUSTRATIONS}

[Plates are in pocket]

Plate 1. Shaded relief map of the western part of the Great Smoky Mountains showing physiographic subdivisions.

2. Geologic map, sections, and inset map of the western Great Smoky Mountains and vicinity.

3. Geologic map of the Kinzel Springs quadrangle.

4. Structure sections of the Kinzel Springs quadrangle.

5. Geologic map and structure sections near Walker Hollow.

6. Structure contour map of the Great Smoky fault surface.

Figure 1. Index map.

2. Map showing generalized geology and biotite isograd

3. Cades Sandstone.

4. Wilhite Formation . .

5. Sedimentary structures in fine-grained rocks interbedded with conglomerate of the Wilhite Formation

6. Columnar section of Shady Dolomite

7. Correlation of Middle Ordovician rocks

8. Block diagram showing geologic interpretation at the northeast end of Mississippian outcrop belts, Kinzel Springs quadrangle.

9. View of Little River Gap .

10. Geologic map of rocks beneath Great Smoky fault in Tuckaleechee Cove window .......

11. Geologic sketch of Cedar Bluff.

12. Geologic section of High Top

13. View of Cades Cove

14. Structural features

15. Geologic sections showing alternative projections of rocks overridden by the Great Smoky fault.

16. Geologic sketch of folds in the Wilhite Formation

17. Section showing idealized relations between arched surface of Great Smoky fault and cleavage.....

18. Restored section showing relative positions inferred for the major units of the Ocoee Series and related rocks and the positions of faults that dismembered them . . . . . . . .

19. Map of parent materials of soils in the southeastern quarter of the Kinzel Springs quadrangle.

\section{TABLES}

TABLE 1. Temperature and precipitation at Gatlinburg, Tenn 


\title{
GEOLOGY OF THE GREAT SMOKY MOUNTAINS, TENNESSEE AND NORTH CAROLINA
}

\section{GEOLOGY OF THE WESTERN GREAT SMOKY MOUNTAINS, TENNESSEE}

\author{
By Robert B. Neuman and Willis H. Nelson
}

\begin{abstract}
Rocks of the Great Smoky Mountains, a part of the Blue Ridge province, have been thrust northwestward over younger more easily eroded rocks of the Valley and Ridge province along the Great Smoky fault.

The overridden rocks in a nearly homoclinal sequence northwest of the fault are also exposed in windows eroded through its upper plate farther southeast. The homoclinal sequence consists of Lower Ordovician to Mississippian rocks. The Mississippian rocks, about 1.500 feet thick, are limestone, shale, and sandstone of the Greasy Cove Formation and siltstone, sandstone, and conglomerate of the Grainger Formation. The Chattanooga Shale represents the uppermost part of the Devonian System. The Chattanooga rests directly upon the Bays Formation of Middle Ordovician age; neither rocks of older Devonian age nor any of Silurian or Late Ordovician ages are present. The Middle Ordovician sequence, about 7,500 feet thick, consists from the top down of red mudrock of the Bays Formation, calcareous shale and sandstone of the Sevier Formation, quartzose calcarenite of the Chota Formation, an older calcareous shale and sandstone of the Tellico Formation, dark calcareous shale of the Blockhouse Shale which includes a sandstone and a limestone member, and at the base, the Lenoir Limestone. Disconformably beneath the Lenoir are interbedded limestone and dolomite in part equivalent to the Mascot Dolomite of Early Ordovician age.

Blockhouse Shale and Lenoir Limestone represent the Middle Ordovician in the Tuckaleechee Cove window. Older rocks here are partly correlatives of the Mascot Dolomite, but some both here and in the Cades Cove window have fossils that occur in older Ordovician formations of the Knox Group.

Rocks of Early Cambrian. Early Cambrian(?), and late Precambrian age, including the Chilhowee Group and the Ocoee Series, form the upper plate of the Great Smoky fault. Thrust faults cut this plate into several parts, each with its own rock sequence.
\end{abstract}

The northwesternmost of these sequences, that of Chilhowee Mountain, contains the youngest rocks of the upper platered shale and sandstone of the Rome Formation (Lower Cambrian) underlain by the Shady Dolomite. The Chilhowee Group beneath, with Lower Cambrian fossils in the Helenmode Formation and the Murray Shale, is classed as Early Cambrian and Early Cambrian(?) in age. The Chilhowee Group consists of siltstone and calcareous and glauconitic sandstone of the Helenmode Formation, Hesse Quartzite, Murray Shale, Nebo Quartzite, Nichols Shale, and the Cochran Formation. Beneath the Cochran, micaceous siltstone, sandstone, and conglomerate, interbedded in various proportions, are assigned to the Sand- suck Formation, the uppermost formation of the Walden Creek Group of the Ocoee Series; the contact between the Cochran and the Sandsuck appears to be conformable in this area.

Southeast of the Chilhowee Mountain sequence, the upper plate of the Great Smoky fault is cut into three principal blocks by thrust faults that obscure original relations of the Ocoee Series. Folds and faults in all three blocks are complex. Metamorphism has altered most of the fine-grained rocks to slates and phyllites, and biotite appears in the southeastern part of the area.

The northwesternmost of these three blocks contains parts of the Walden Creek Group, the Wilhite Formation for the most part, and possibly a small part of the Licklog Formation. The Wilhite consists of a main body that is largely siltstone, and a conglomerate part. The composition and sedimentary structures of the conglomerate, and the sandstone and dark argillites associated with it, indicate that detrital constituents were derived from a crystalline source toward the north and transported down steep slopes into a poorly ventilated basin. Contrasting composition and structure of the main siltstone body, which contains minor amounts of sandstone, limestone, and limestone breccia, indicate that deposition was in better circulating water and that little material was added from a bordering crystalline source; the brecciated limestone, however, indicates that gravity sedimentation was active.

The central structural block consists of Metcalf Phyllite, representing a small part of the Snowbird Group, and the Cades Sandstone, not assigned to any of the groups of the Ocoee Series. Most of the Metcalf, largely a light-greenish-gray phyllite and siltstone, apparently underlies the Cades. The Cades is coarse-grained sandstone or graywacke, at least 4,000 feet thick. containing a few boulder beds and associated dark argillite and siltstone. The change from Metcalf to Cades sedimentation is interpreted to indicate a deepening of the depositional trough and an emergence of crystalline highlands, probably to the southeast. which produced conditions that generated turbidity currents.

The southeastern structural block is formed of the Elkmont Sandstone of the Great Smoky Group, presumed temporal equivalent of the Walden Creek Group. The formation is at least 6,000 feet thick and consists of feldspathic sandstone in prominently graded beds, and interbedded dark argillite and siltstone. The Elkmont is similar to the Cades, and similar processes and sources produced them both.

There were at least two stages of deformation. Metamorphic and structural discontinuities across the Great Smoky fault indicate that slaty cleavage, metamorphic minerals, and many of the folds and faults of the upper plate and perhaps the 
larger folds and faults of the lower plate preceded its development. The later stage includes the Great Smoky fault itself, other faults related to it, and renewal of movement along some older faults. Windows through the upper plate of the Great Smoky fault demonstrate northwestward movement of at least 8.5 miles. Also assigned to this stage is the Oconaluftee fault, which is a right-lateral transcurrent fault towards the east, but which becomes a thrust fault as its strike swings from northwest to northeast.

Post-Paleozoic unconsolidated surficial deposits include alluvium of possible early Tertiary age, younger Pleistocene colluvium and alluvium on steep mountainsides, and Recent alluvium. The composition of the older deposits indicates that at the time they were formed the landscape was much the same as it is at present. The younger deposits probably result from the cold climates of the Pleistocene.

\section{INTRODUCTION}

This report is the last of the four parts of Professional Paper 349 on the geology of the Great Smoky Mountains in Tennessee and North Carolina. The field studies that led to these reports began in 1946 under the direction of Philip B. King and continued into 1954. More than a dozen geologists participated in the work. This report and its companions deal with the geology of different parts of the project area; in addition, some phases of the geology have been discussed in journal articles. Although the reports have different authors, they treat contiguous areas, and many of the interpretations were worked out jointly. Comparison of the reports will indicate that complete agreement has not been reached on several interpretations in this geologically complex region. Where interpretations differ, no master one has been selected, so that some interpretations preferred by the authors of this report differ from those of their colleagues.

\section{LOCATION}

The crest of the Great Smoky Mountains forms the boundary between the States of North Carolina and Tennessee (fig. 1). Much of the mountain area is in the Great Smoky Mountains National Park, and the geologic interpretation of the park was the primary aim of the study. The area of this report covers about 200 square miles of the park in Tennessee and the adjoining area to the north. It extends northward to the outcrop of the base of the Middle Ordovician Series,

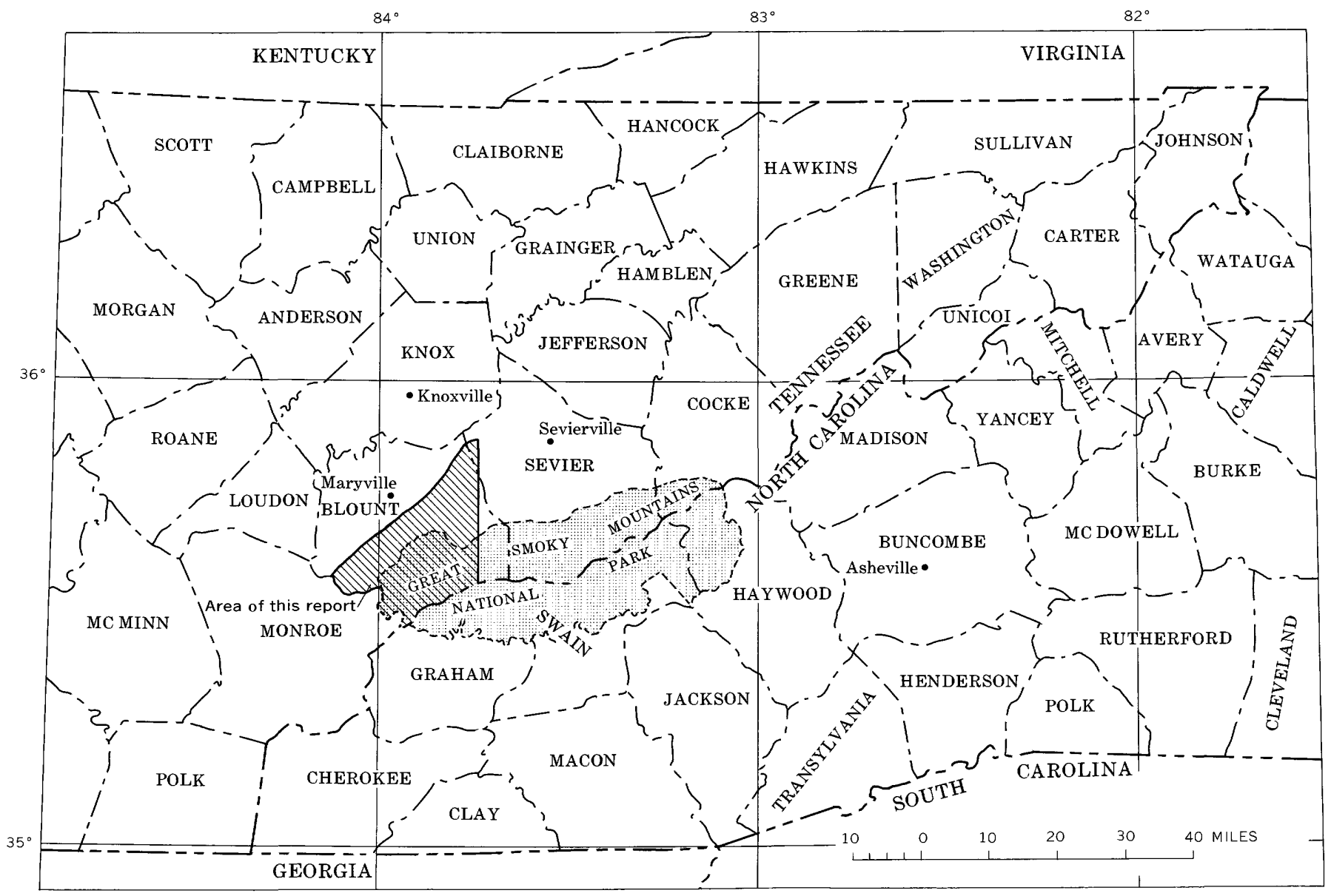

Figure 1.-Index map showing location of Great Smoky Mountains National Park and the area of this report. 
westward and southwestward to the $84^{\circ} 07^{\prime} 30^{\prime \prime}$ meridian and the Little Tennessee River, southeastward to the State line and eastward to the $83^{\circ} 45^{\prime}$ meridian.

\section{GEOGRAPHY \\ PHYSIOGRAPHY}

The report area contains parts of the southern sections of the Valley and Ridge and Blue Ridge provinces (Fenneman, 1938, p. 265-278, 171-194), the northwestern foot of Chilhowee Mountain forming the boundary. The part of the Blue Ridge province within the area consists of the foothills, the coves, and the main range of the Great Smoky Mountains.

The "slaty knobs" that form a large part of the southeastern border of the Valley and Ridge province were described by Safford $(1869$, p. 46). "These knobs are crowded together without order, and, where most numerous, form wild labyrinths of conical hills, from which a stranger, once off the beaten track, might not easily extricate himself." Topographic maps show that the knobs have a more regular pattern and a relief from 150 to 250 feet. Topographic grain parallels the northeast-southwest structural grain, emphasized more by the drainage than by the heights of land. Most streams follow beds of easily abraded rock, but from place to place cut across regional trends, both in their lower parts and at headwater gullies.

Smoother topography, more characteristic of the Valley and Ridge province, occurs northwest of the slaty knobs.

The foothills of the Great Smoky Mountains, including Chilhowee Mountain, are long ridges and intricately dissected highlands broken by narrow valleys. Nestled among the foothills are the broad lowlands of Cades, Tuckaleechee, and Miller Coves, each of which resembles a part of the Valley and Ridge province. The term "cove" is appropriately used locally for these broad lowlands, but it has also been applied to many areas that are simply wide habitable parts of stream valleys in the mountains.

The main range of the Great Smoky Mountains, although the principal height of land, is not the divide between Atlantic and Gulf drainage which lies many miles to the southeast. The crest stands at nearly 5,000 feet for a long distance in the eastern part of the area, but to the southwest it descends rapidly to 1,086 feet at the Little Tennessee River, rising again beyond.

The physiographic boundaries drawn on plate 1 of the present report follow Fenneman (1938), except for changes in detail as follows:

1. The main boundary between the Blue Ridge and Ridge and Valley provinces is drawn along the topographic base of Chilhowee Mountain rather than at the trace of the Great Smoky thrust fault which lies high on the mountainside (cf. Fenneman, 1938, p. 173). The steep stony wooded slope of the northwest face of this mountain is characteristic of slopes elsewhere in the Blue Ridge Province.

2. Miller Cove should be considered in the same physiographic category as Cades and Tuckaleechee Coves because its rolling arable surface has a deep residual soil mantle derived largely from dolomite; in this respect it is more like the coves and the Valley and Ridge province than it is of the narrow alluviated valleys of the Blue Ridge province.

3. Subdivision of the Blue Ridge province into foothills and main range is of local importance; it is based on the greater relief and coarser topographic grain of the main range and on the fact that largest tributaries of the principal streams originate on its slopes.

\section{HUMAN GEOGRAPHY}

More than half the area studied is mountainous and sparsely populated, but the more arable valleys and foothills are occupied by small farms. Early settlements reached well into the mountainous areas along creek valleys, but these had been abandoned long before establishment of the park. Cades Cove is the only part of the park that is now cultivated. Mountainous areas outside the park are largely timbered, although many of the broad valleys are occupied by small farms. Settlement is denser northwest of Chilhowee Mountain where improved roads that lead to the industrial area near Maryville permit many people to commute to work.

Most people in the more hospitable areas live on small farms, centered about such lowland areas as Happy Valley, Tallassee, Miller Cove, Tuckaleechee Cove, Cades Cove, and the broad area underlain by Paleozoic rocks to the northwest of Chilhowee Mountain. In these areas public roads furnish ready access, mail is delivered, and electric power and telephone service is generally available.

The only municipality within the area is Townsend in Tuckaleechee Cove. Between 1920 and 1935, Townsend thrived on the activities of the Little River Railroad and the lumber industry. Since then its population has dwindled, although recently the tourist business rejuvenated the economic life of the community.

Primary access roads follow the principal streams. The Little River was paralleled by a railroad in the early 1900 's and is now flanked by paved highways; the one on the southwestern side, recently constructed, is designated State Highway 73. The Little Tennessee 
GEOLOGY OF THE GREAT SMOKY MOUNTAINS, TENNEASEE AND NORTH CAROLINA

River is followed on its northeastern side by U.S. Highway 129 that connects Fontana Village and other points in North Carolina with Maryville, Tenn.

Within the park a few roads are maintained by the National Park Service for patrol and access purposes, and most of these roads are restricted to official use. A graveled and tortuous public road traverses a part of the mountains through Rich Mountain Gap, connecting Tuckaleechee Cove and Cades Cove.

Foot trails of two categories are shown on the topographic map. Maintained trails were built between 1935 and 1941 by the Civilian Conservation Corps. Trails indicated as not maintained are old wagon roads, trails formerly used for driving livestock, or old foot trails that are legacies from the mountaineers that formerly inhabited the area; for the most part they are overgrown and obstructed by fallen trees.

Outside the park there are few permanent roads in the mountainous area, although temporary roads are constructed for hauling timber.

\section{FIELDWORK}

Geologic work in the report area began in April 1949 with a study of the Middle Ordovician rocks (Neuman, 1955) and continued, with interruptions, to December 1953. Nelson joined Neuman in the detailed mapping of a part of Tuckaleechee Cove from January to March 1951; he returned to the area in April 1953 and shared with Neuman the mapping of most of the mountainous area until December 1953. The sections on petrography, petrology, and metamorphism in this report were prepared by Nelson. The rest of this report and most of its illustrations were prepared by Neuman.

Harold E. Malde participated in the project for 10 months in 1952, and in 1953 when he helped in the mapping of Chilhowee Mountain and studied the surficial geology of Dry Valley.

Geologic mapping in the east-central part of the Kinzel Springs quadrangle (pl. 3) is by Philip B. King. George D. Swingle studied the Chilhowee Group near Little River, and Charles A. Tucker, Jr., investigated the Shady Dolomite and Rome Formation in Miller Cove, while they were graduate students at the University of Tennessee; their reports were prepared as master of science theses.

Field methods for the most part were those of elaborate reconnaissance with traverses across the grain of the country. At only a few places were beds or contacts actually traced. All roads, trails, and other means of access were studied, as were all major streams, and traverses between these were spaced as was deemed necessary.

\section{ACKNOWLEDGMENTS}

The cooperation of personnel of the National Park Service attached to the Great Smoky Mountains National Park is gratefully acknowledged. The Park Naturalist Arthur Stupka, Ranger Ralph Shaver, and Warden Wesley Ogle rendered particularly valuable assistance as the work progressed.

While the geology of the western part of the Great Smoky Mountains was being mapped, Philip B. King, Jarvis B. Hadley, and Warren Hamilton were mapping the same range to the east. To a large degree the observations and interpretations of this report are based on information and stimulation offered by these geologists. Among the visitors who also stimulated the work were Dorothy Carroll, P. E. Cloud, Jr., C. S. Denny, James Gilluly, Charles Milton, and G. M. Richmond, all of the Geological Survey; Prof. Francis Pettijohn, of the Johns Hopkins University; Dr. Stanislaw Dżułyński, of the Polish Academy of Science; and Dr. Marion Książkiewicz, of the Jagellonian University, Crakow, Poland.

\section{NATURE AND EXTENT OF EXPOSURES}

Weathering and plant growth are encouraged by warmth and by heavy rainfall that is distributed through the year (table 1). In wooded areas dense vegetation makes access difficult and provides a thick humic layer. Alluvium and colluvium also mantle bedrock over wide areas.

TABLe 1.-Temperature and precipitation at Gatlinburg. Tenn.

\begin{tabular}{|c|c|c|}
\hline \multicolumn{3}{|c|}{ [From U.S. Weather Bureau, 1954] } \\
\hline & $\underset{\left({ }^{\circ} F^{\prime}\right)}{\text { Temperature }}$ & $\begin{array}{c}\text { Precipitation } \\
\quad \text { (Inches) }\end{array}$ \\
\hline January & 39.8 & 4. 32 \\
\hline February & 42. 2 & 4. 29 \\
\hline March & 48. 6 & 5. 22 \\
\hline April_. & 56.9 & 4. 13 \\
\hline May . . . . . . . . . . . & 64. 9 & 4. 70 \\
\hline June & 72.4 & 4. 81 \\
\hline July & 75. 1 & 5. 69 \\
\hline August $\ldots$ & 74.3 & 5. 64 \\
\hline September & 70. 1 & 2. 82 \\
\hline October & 58. 4 & 2. 95 \\
\hline November & 47. 5 & 2. 45 \\
\hline December & 41. 4 & 4. 46 \\
\hline Average or total & 57. 7 & 51.48 \\
\hline
\end{tabular}

Exposures of fresh rock are virtually continuous for long distances along many streams. Much rock is also exposed on steep hillsides, and at a few places the more massive resistant rocks form cliffs. Most hillside exposures are only low ledges that barely project above the leaves and brush on the forest floor.

Little rock is exposed along most ridge crests where soil formation and weathering are profound. In many 
places complete soil profiles are preserved. Soils developed from coarse-grained rocks are generally thicker than those developed from fine-grained shaly rocks, because the former tend to disintegrate more readily upon chemical weathering. Much of the soil contains fragments of weathered rock that were lifted into it by the uprooting of trees (Denny and Goodlett, 1956, p. 64).

Advanced chemical decomposition is shown by the widespread occurrence of saprolite "thoroughly decomposed, earthy, but untransported rock" (Becker, 1895, p. 289-290). In most of the saprolite feldspar and the micaceous minerals have been altered by hydration and oxidation, and the resulting texture is that of a gritty clay. Because weathering processes have acted in place and volume loss has been small, many features of the fresh rock are well preserved in saprolite, and sedimentary and metamorphic textures and structures may be observed and measured in it.

Colluviation is now active, but was probably even more so in the past. (See section on "Post-Paleozoic history," below.) Landslide scars on some steep slopes and many large bowed tree trunks attest to this activity. Colluviation forms a creep mantle, consisting of fragments of fresh and weathered rock which blankets slopes. Here the general character of the bedrock upslope can be determined by the geologist.

\section{STRUCTURAL FRAMEWORK}

Major thrust faults separate the larger stratigraphic subdivisions from each other (pls. 2-4) and form the basis for the organization of the stratigraphic section of this report.

The Ocoee Series to the southeast of the Miller Cove fault and above the Great Smoky fault is separated into several slices by other major thrust faults. The Ocoee Series contains no fossils, so that, whereas the rock sequences within fault slices are known, interpretation of relations between formations in different slices is uncertain. In general, formations between two throughgoing thrust faults are classed as separate groups. These groups are described in geographic order from southeast to northwest.

The formations northwest of the Miller Cove fault are largely of Paleozoic age, and most of them can be dated by fossils. They are described in conventional order, from oldest to youngest.

\section{METAMORPHISM}

From northwest to southeast across the area, the effects of metamorphism become increasingly apparent, most notably in the Ocoee Series. The Paleozoic rocks on the northwest, including the Chilhowee Mountain structural block, and in the windows are least altered and at the most have only a weak fracture cleavage. Slaty cleavage of the fine-grained rocks is pronounced southeast of the Miller Cove fault, but sandstones are little altered. At the southeastern margin of the area, biotite is abundant in the fine-grained rocks, and the sandstones are recrystallized. Because belts of comparable metamorphism (fig. 2) trend northeast-southwest, they are generally parallel to formation boundaries, and each formation shows the effect of metamorphism somewhat differently.

Nowhere does the metamorphism obscure the megascopic sedimentary character of the rocks. In detail, however, the change from shale to slate to phyllite is accompanied by an increase in the abundance, size, and regularity of orientation of micaceous minerals-sericite, chlorite, and biotite. Biotite does not appear in the northwestern part of the Ocoee outcrop area; near the middle of the area a few microscopic flakes of biotite occur, and it becomes more abundant, and chlorite less abundant, toward the southeast. Alteration of sandstone follows a similar pattern. Original grain shape and size are preserved in the northwestern part of the area, and minerals here are least altered. With increasing metamorphism, quartz grains are flattened and recrystallized to impart a foliation. The more highly metamorphosed rocks are rich in albite, perhaps derived from more calcic plagioclases, and crystals of it and other feldspars are more equidimensional than adjacent quartz. The matrix of these rocks is rich in biotite.

\section{LATER PRECAMBRIAN ROCKS} OCOEE SERIES

The Ocoee Series is a thick body of unfossiliferous, mainly clastic sedimentary rocks that underlies much of the mountainous area of eastern Tennessee and western North Carolina. The Ocoee was named by Safford $(1856,1869)$ for exposures along the Ocoee River southwest of the Great Smoky Mountains. Safford (1869, p. 183-198) described outcrops of the Ocoee along the Little Tennessee River and portrayed their relations in a section crossing the center of the present report area.

Units recognized in the present report can be identified in Safford's descriptions. He mentions (1869, p. 190) the occurrence of Ocoee strata, here called Sandsuck Formation, at the northwestern base of Chilhowee Mountain. Southeast of Chilhowee Mountain he described (p. 189) coarse conglomerate, slate (including pale-green slate), and limestone breccia, here called the Wilhite Formation. Safford identified Paleozoic rocks in "Tallassee Cove," here called the Calderwood window. Farther southeast he reported increas- 


\section{EXPLANATION}

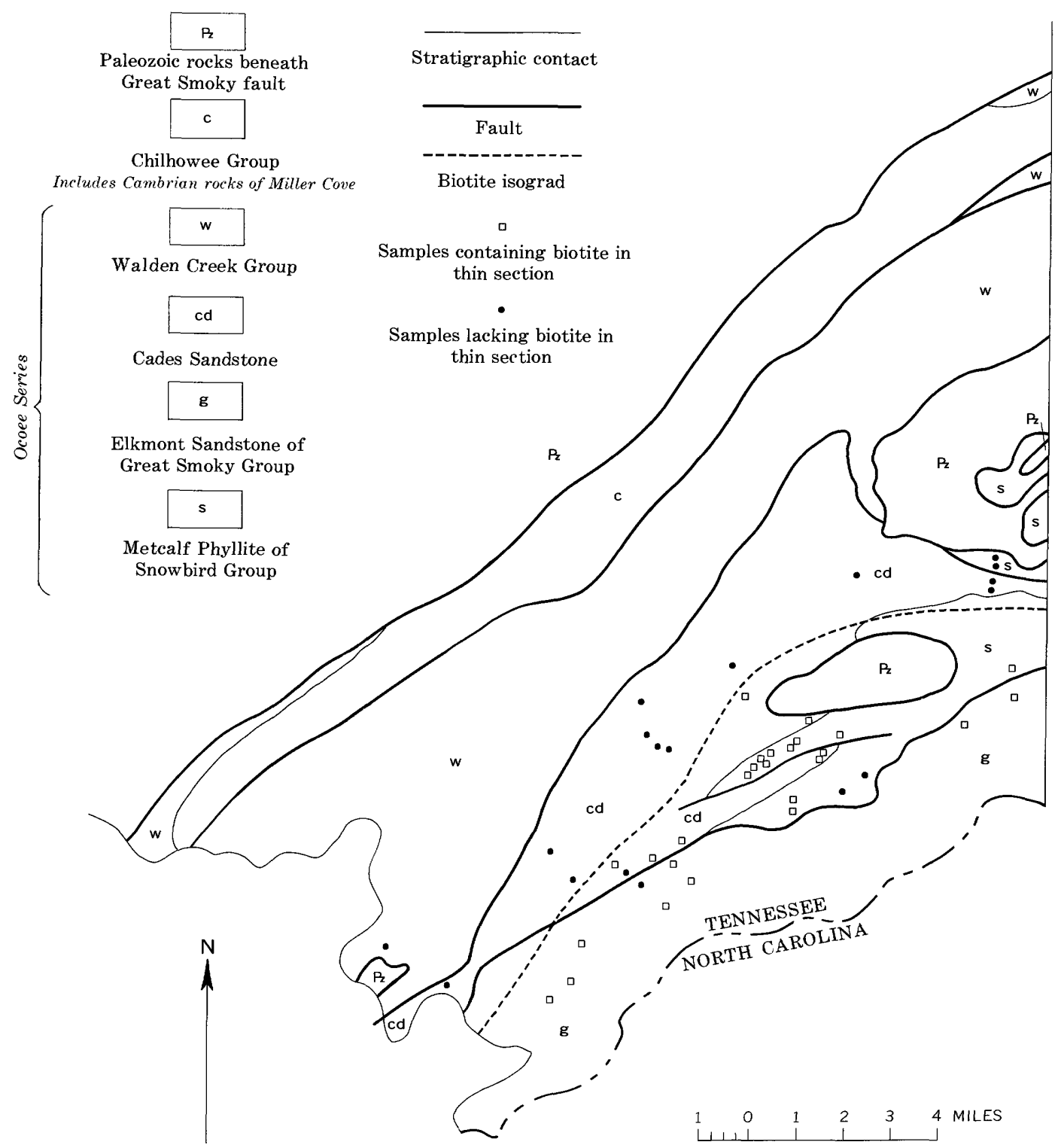

FIGURE 2.-Map showing generalized geology and biotite isograd in the western Great Smoky Mountains, and the location of samples on which it is based.

ing abundance of conglomerate or graywacke toward the State line in rocks here termed the Cades Sandstone and the Elkmont Sandstone.

The area of the present report was mapped by Keith (1895, 1896a) for the Knoxville and Loudon folios. Keith subdivided the rocks of the mountains into formations but he did not formally use the term Ocoee Series for them; he classed these rocks as "age unknown." In the later Asheville (Keith, 1904) and Nantahala (Keith, 1907a) folios, Keith revised his earlier classification and abandoned many of the names he had used earlier. The present classification of the Ocoee Series utilizes parts of both classifications and introduces some new units.
The Ocoee Series has been divided into three groups (King and others, 1958) that contain related sequences of formations. These groups are more fully developed to the east, but each is represented by one or more formations in the present area. The Great Smoky Group is here represented by the Elkmont Sandstone, the Snowbird Group by the Metcalf Phyllite, and the Walden Creek Group by the Wilhite, Licklog(?), and Sandsuck Formations. The Cades Sandstone of the Ocoee Series has not been assigned to any of these groups.

\section{GREAT SMOKY GROUP}

The rocks that form the main part of the Great Smoky Mountains are included in the Great Smoky 
Group (King and others, 1958, p. 957). The term is taken from the "Great Smoky conglomerate" of Keith's later classification of these rocks "named for its notable development in the Great Smoky Mountains southwest of Pigeon River" (Keith, 1904, p. 6). Only the Elkmont Sandstone of the Great Smoky Group is preserved in the area of plate 2 , but the overlying Thunderhead and Anakeesta Formations crop out to the east (King, 1964, pl. 1).

\section{ELKMONT SANDSTONE}

Coarse-grained rocks of the Elkmont Sandstone form the crest of the Great Smoky Mountains through the present report area and probably continue southwestward far beyond the Little Tennessee River. The formation was named (King and others, 1958, p. 958) for coarse- to medium-grained sandstones in the Gatlinburg quadrangle near Elkmont, Sevier County, Tenn., where it is distinguished from the overlying Thunderhead Sandstone by its finer texture and other features.

DESCRIPTION

The Elkmont Sandstone, which is the most massive and resistant formation in the area, supports the crest of the range here. Nevertheless its outcrops are generally poor, and the area that it underlies is commonly covered by residual and colluvial materials.

The Elkmont Sandstone consists of thick-bedded sandstone that ranges in texture from medium grained to conglomeratic, and interbedded finely laminated black and dark-gray argillite and siltstone. Through most of the Elkmont, sandstone predominates, with argillite and siltstone forming thin partings between much thicker beds of sandstone. At some places the dark fine-grained rock forms units as thick as 100 feet, and at other places these contrasting rocks alternate in about equal proportions in beds 2-6 feet thick.

Most sandstone beds grade from a coarse-grained base to dark fine-grained rock at the top. The gradation is composite; most beds consist of several graded layers a few inches to a foot thick without argillite tops, and the bases of some of these layers lie on scoured surfaces. Grain contrasts are visible on close inspection of even the most massive-appearing outcrops.

Spheroidal concretions 6-12 inches in diameter are conspicuous at some exposures. They are most noticeable on naturally weathered surfaces (see Stose and Stose, 1949, pl. 3, fig. 1) where they are outlined by a recessed ring about half an inch wide; on fresher surfaces they form rusty ovoids. The rock in these concretions is slightly more calcareous than that outside, and some of the concretions have slate chips in their centers.
The sandstone, which is poorly sorted, contains detrital grains set in a micaceous matrix. The rock would be a highly quartzose graywacke according to some classifications, but use of this term has long been debated (MacCulloch, 1814, p. 457). The fresh sandstone is medium to dark gray; its finer grained parts are darker than the coarser because of a higher proportion of micaceous matrix.

Subangular grains of quartz and feldspar are the principal consituents of the sandstone. Sorting is poor. Granules 2-4 $\mathrm{mm}$ in diameter are common, but a few are larger. Grains as small as silt size are common, but are less conspicuous than the larger sizes. Quartz forms $60-75$ percent of the rock, albite $1 / 2-10$ percent, potassic feldspar $1 / 2^{-5}$ percent, sericite $15-25$ percent, biotite 10-15 percent, and calcite 5 percent or less.

Most of the quartz is clear or milky, but some grains larger than $1 \mathrm{~mm}$ are blue. Under the microscope, quartz grains are recrystallized into lenticular mosaics whose long dimensions are parallel to cleavage; all show undulatory extinction. The albite contains inclusions of sericite but is undeformed. About half the potassic feldspar shows microcline twinning, and all is permeated with sericite and other alteration products. A few patches of crystalline calcite are comparable in size to the quartz grains. Some of this may be detrital, but it may also have been derived from the reconstitution of plagioclase that was more calcic than that now present.

About 20 percent of the rock is micaceous matrix formed of sericite and biotite. The sericite flakes range from 0.01 by $0.05 \mathrm{~mm}$ to 0.05 by $0.4 \mathrm{~mm}$, with their long dimensions parallel to the rock cleavage, deflected around detrital grains. Biotite crystals are similar to sericite in size, shape, and orientation, but they occur in clusters 0.5 by $1.5 \mathrm{~mm}$. Flakes of a yellow anhedral mineral that may be baddeleyite were seen in the matrix of one specimen.

Heavy minerals from sandstones of the Elkmont, Cades, and related formations were described by Carroll, Neuman, and Jaffe (1957). Most samples from the Elkmont were of saprolite collected at scattered points. At one locality each of five successive layers was sampled; other samples were made of the concretions and adjacent fresh rock and saprolite. Fresh rock from one layer yielded zircon, tourmaline, apatite, ilmenite, and magnetite. Saprolite from the same layer contained comparable amounts of unaltered zircon and tourmaline, but apatite was missing, magnetite was altered to hydrous iron oxides, and some ilmenite was altered to anatase (Carroll and others, 1957, p. 178). Pyrite, visible in many places, was not present in this sample. 
Ilmenite and zircon were identified in all samples, with ilmenite forming 25-90 percent of the heavy minerals. Zircon was the only nonopaque mineral in some samples, but tourmaline occurs in small amounts in most samples and formed 34 percent of the heavy fraction of one sample. The range of variation is contained in the suite of closely spaced samples. Tourmaline was present in small amounts in two of the five samples, but was more abundant than zircon in one sample. Similarly, opaque minerals were more abundant than nonopaques in all samples except the one rich in tourmaline. Three varieties of zircon occur in different proportions (Carroll and others, (1957, p. 182-183) : (1) purple to pink fresh grains, most of which are well rounded; (2) metamict grains, with dense interiors surrounded by clear outer rims; and (3) clear colorless grains with rounded to subrounded outlines. Most of the tourmaline is gray or brown, in broken and angular fragments (Carroll and others, 1957, p. 182).

The samples collected from the Elkmont were compared with those of the Cades, but no significant differences between them could be detected (Carroll, and others, 1957 , p. 185 ). In addition, age determinations were made from the lead/alpha activity ratios of the zircons, those from the Elkmont giving values ranging from 620 to 1,140 million years (Carroll and others, 1957, p. 187). The spread of age determinations suggests that the source rocks from which the Elkmont and Cades were derived were of several different ages, or perhaps that metamorphism has variably affected the zircons.

The dark siltstones, argillites, and slates of the Elkmont are marked by parallel laminations, $1-10 \mathrm{~mm}$ apart, that express minor textural variations. They are composed dominately of sericite, but contain small amounts of chlorite and fine-grained biotite. The sericite, chlorite, and biotite grains range from 0.01 by $0.05 \mathrm{~mm}$ to 0.03 by $0.1 \mathrm{~mm}$ in size. They are generally oriented parallel to the slaty cleavage and are concentrated in shear laminae $0.01-0.03 \mathrm{~mm}$ thick at intervals $0.02-0.1 \mathrm{~mm}$ apart. Most of these rocks are somewhat silty. Angular quartz, $0.01-0.1 \mathrm{~mm}$ in size forms $10-60$ percent of their volume and feldspar only minor amounts. A few beds contain scattered clastic grains of quartz and feldspar large enough to be identified megascopically, and the more prominent beddingplane partings are coated with large flakes of detrital mica.

\section{WEATHERING FEATURES}

The mineralogic composition of the sandstones of the Elkmont makes them particularly susceptible to weathering. Calcite has been dissolved, and feldspars are cloudy on the surface of every outcrop not regularly washed by running water. More advanced decomposition reduces the feldspars and micaceous minerals to clays, and the rock becomes lighter colored. The ultimate result of residual weathering, to be found on most ridge crests, is saprolite which gives way upward to soil. The dark-gray fine-grained rock is less susceptible to weathering, but in many places where sandstone has been altered to saprolite, dark slate and siltstone are soft and ash-gray. The effect of grain size on the rate of weathering is apparent where decomposition is less advanced; the finest grained laminae commonly retain their dark color, whereas silty and sandy beds that have greater permeability are light gray and soft. Oxidation of pyrite to sulfuric acid was probably an important agent in weathering. Surfaces that are protected from wetting are coated by an efflorescent white delicately fibrous sulfate.

Soils of the Elkmont are infertile and were never much used for agriculture. They are gray-brown stony podzols, and in many places the gray leached zone characteristic of the profile of this soil group is preserved (Baldwin and others, 1938, p. 997-998).

$$
\text { LOCATION AND NATURE OF EXPOSED SECTIONS }
$$

Within the area of outcrop of the Elkmont of plate 2, only the exposures along U.S. Highway 129 afford more than scattered outcrops, and even here most of the rock is weathered to saprolite, and covered intervals are numerous. The fault boundary between the Elkmont and Cades Formations crosses the highway in a topographic saddle 1.9 miles east of the village of Calderwood. For 300 feet southeast of the saddle the rocks are structurally jumbled, but to the southeast, beds of the Elkmont Sandstone through a belt about 4,000 feet wide dip regularly and gently $\left(15^{\circ}-\right.$ $25^{\circ}$ ) southeast; these are medium- to coarse-grained sandstone layers 6 inches to 2 feet thick, separated by dark-gray argillite partings $2-6$ inches thick. These outcrops, and those at lower altitudes along the shore of Calderwood Lake, resemble the Cades Sandstone in that they lack blue quartz. Their composite bedding and sorting characteristics, and the lack of grains composed of intergrowths of quartz and feldspar typical of the Cades Sandstone, strongly suggest that they should be included with the Elkmont rather than the Cades.

Southeast of these gently dipping beds, dark slate and siltstone about 300 feet thick dip steeply to the northwest or are overturned steeply to the southeast; this unit is underlain on the southeast by thin-bedded medium-grained sandstone containing blue quartz that is interbedded with about equal amounts of argillite through a thickness of about 600 feet. Where the high- 
way enters the valley of Parson Branch, sandstone beds are thicker and fine-grained rocks are less conspicuous.

An abandoned and partly overgrown quarry 1,000 feet southeast of the highway bridge over Parson Branch contains excellent fresh exposures of this part of the sequence. The rocks in Parson Branch and for about 1,500 feet to the southeast dip about $20^{\circ}$ southeast. Identical rocks with steep northwest dips crop out along that part of the highway that trends southwest. As the road approaches the State line at Deals Gap, outcrops are fewer and their dip could not be determined; but a few hundred feet north of Deals Gap a conspicuous outcrop of coarse-grained gritty sandstone contains concretions, and at Deals Gap the coarse-grained sandstone has large biotite crystals.

STRATIGRAPHIC RELATIONS

The Elkmont Sandstone is overlain by the Thunderhead Sandstone in the Thunderhead and Gatlinburg quadrangles where gritty and conglomeratic beds are common in the Thunderhead but are rare in the Elkmont (King, 1964, p. 30-31). In these quadrangles the contact between the Thunderhead and Elkmont descends stratigraphically southwestward, so that the Elkmont of the western Great Smoky Mountains contains the oldest beds of the Great Smoky Group of the range. The base of the Elkmont, however, is everywhere concealed by faulting, so that its stratigraphic relations to lower units are unknown.

The thickness of the Elkmont Sandstone preserved in the report area is uncertain, but estimates from the structure sections indicate that as much as 6,000 feet of it is present. In the type area in the Gatlinburg quadrangle its thickness is as much or more, again with the base faulted off (King, 1964, p. 30-31).

\section{SNOWBIRD GROUP}

The type area of the Snowbird Group is along the Pigeon River at the eastern end of the Great Smoky Mountains (Hadley and Goldsmith 1963, p. B24). At the type area the Snowbird consists, in descending order, of the Pigeon Siltstone, Roaring Fork Sandstone, Longarm Quartzite, and Wading Branch Formation, with granite and gneiss beneath. It corresponds to the Snowbird Formation of Keith (1904). The sole representative of the Snowbird Group in the western part of the Great Smoky Mountains is the Metcalf Phyllite, a unit that has been traced into the Pigeon Siltstone (King, 1964, p. 28).

\section{METCALF PHYLLITE}

Light- to medium-gray phyllite and fine-grained sandstone of the Metcalf Phyllite underlies the eastern margins of Cades Cove. The formation was named
(King and others, 1958, p. 957) from Metcalf Bottoms on the Little River in the Wear Cove quadrangle (King, 1964, p. 25), a short distance east of the report area. In the Knoxville folio (Keith 1895) the rocks surrounding Cades Cove were mapped as Wilhite Slate, although Keith (1895, p. 2) mentioned that these rocks were more altered there than elsewhere.

DESCRIP'TION

The Metcalf is a nearly homogeneous body of lightcolored phyllite and minor amounts of siltstone and sandstone. Most of it is light and medium greenish gray. Stratification is commonly obscure, but laminations 1-5 $\mathrm{mm}$ thick can be distinguished in many places, the darker layers being slightly finer grained than the lighter. In the few fine-grained sandstone beds, laminations are conspicuous and are due more to concentration of dark minerals in the darker layers than to alternation of grain size.

Strong closely-spaced slaty cleavage, the most striking feature of the Metcalf, intersects bedding at various angles. In some areas the cleavage has a uniform dip, but over wide areas this cleavage has been deformed by one or more sets of wrinkles, plications, or folds. Elsewhere, the foliation is irregular and is formed of at least two planes that intersect at low angles to produce irregular, nodular, gnarled outcrops.

In thin section about 80 percent of the phyllite is composed of micaceous minerals: chlorite and sericite in nearly equal amounts, small amounts of biotite, and in places a few sheaves of penninite. These minerals occur together as intergrown flakes that range in size from 0.01 by $0.04 \mathrm{~mm}$ to 0.02 by $0.1 \mathrm{~mm}$. The remaining silt fraction is nearly all quartz, but includes a little albite, potassic feldspar, and calcite; heavy minerals in trace amounts include sphene, zircon, tourmaline, rutile, apatite, magnetite, pyrite, and leucoxene. The quartz and feldspar grains range from 0.02 to 0.5 $\mathrm{mm}$ in diameter; those about $0.3 \mathrm{~mm}$ are the most abundant. The larger quartz grains have been deformed and recrystallized into lenticular mosaics, and all show undulatory extinction.

Most sandstone of the Metcalf differs from the phyllite chiefly in abundance of clastic grains, for their mineralogy and that of the matrix is the same as the phyllite.

A somewhat coarser grained sandstone in the Metcalf crops out north and west of Whiteoak Sink (pls. $2,3)$. It is medium grained $(0.25-0.5 \mathrm{~mm})$, even textured, and is composed largely of rounded quartz and subordinate feldspar. Where fresh, it is greenish gray; where weathered, it is olive green and flecked by chalkwhite feldspar grains. Sandstone beds are set apart by intercalations of phyllite, mostly medium gray like the 
bulk of the Metcalf, but in places darker. On the lower slopes of Rich Mountain in Water Hollow, and for about 1 mile westward (pl. 3), this sandstone forms bluffs without phyllite partings. Elsewhere, partings and thicker beds of phyllite occur at intervals of 3 inches to 4 feet, and in some places sandstone and phyllite crop out in about equal proportions.

\section{WEATHERING FEATURES}

At most exposures the Metcalf is weathered to olive hues, and the original subtle color contrasts between bedding laminations are emphasized. Variation in color also follows cleavage planes which are thus easily mistaken for bedding.

The residuum derived from the Metcalf is mostly less than a foot thick, in contrast with much greater thickness of residuum over coarse sandstones. Weathered but undisturbed phyllite is common in the shallow pits left by the roots of downed trees. The weathered zone, however, varies in thickness from a maximum in the roadcut at Crib Gap (pl. 2) where the weathered olive phyllite with many surfaces coated by thin red clay seams is at least 50 feet thick. In many streambeds and valley walls fresh rock lies at the surface.

Fragments of Metcalf Phyllite, some of huge size, are readily detached from outcrops along planes of structural weakness. The phyllite is therefore more subject to alluvial and colluvial transport than are the more massive rocks, and its fragments contribute to the colluvial and alluvial deposits of the lower slopes in amounts disproportionate to its outcrop area higher up. Small landslides east of Crib Gap have resulted from the transection of cleavage planes by excavations for highway construction.

\section{STRATIGRAPHIC RELATIONS}

There is little doubt that the Metcalf Phyllite is equivalent to at least a part of the Pigeon Siltstone farther east, and the transition between them has been mapped by King (1964). Differences in composition, amplified by their different response to metamorphism, warrant their discrimination. What part of the Pigeon is contained in the Metcalf, cannot be established. The sandstone near Schoolhouse Gap resembles somewhat the Roaring Fork Sandstone, suggesting that equivalents of the lower part of the Pigeon are represented here.

Within the report area (pl. 2) the Cades Sandstone seems to be in stratigraphic contact with the Metcalf Phyllite. At most places in this area the tops of the beds of the Cades face away from its contact with the Metcalf, which implies an upward sequence from the Metcalf to the Cades, although the Metcalf itself does not display features by which its top and bottom can be determined (p. D13). However, in the short segment of the Cades-Metcalf contact that passes through Whistling Gap in a separate fault block to the southeast of the main outcrop area (pl. 2), the Metcalf apparently overlies the Cades. The Cades Sandstone and the Metcalf Phyllite may therefore intertongue.

The thickness of the Metcalf Phyllite is undertermined. Its structural complexity, uniform character, and lack of primary structures that would indicate tops and bottoms of beds, prevent determination of a sequence. Structure sections suggest a maximum thickness of 6,000 feet and a minimum of 1,000 feet, according to the amount of structural duplication assumed. However, if the Metcalf intertongues with the Cades Sandstone, as suggested above, it may extend through a stratigraphic interval much thicker than its exposures would indicate.

\section{UNCLASSIFIED FORMATION OF OCOEE SERIES}

Several apparently related bodies of sandstone, which cannot conveniently be assigned to any of the three groups of the Ocoee Series, crop out in the foothills just north of the main range of the Great Smoky Mountains. The Cades Sandstone of the present area is one of these bodies. It appears to be closely related stratigraphically to the Snowbird Group, but its rocks resemble much more those of the Great Smoky Group.

\section{CADES SANDSTONE}

The Cades Sandstone consists of coarse-grained to conglomeratic sandstone interbedded with dark-gray argillite and siltstone. The name is adapted from Cades Conglomerate of Keith's classification of the rocks here called Ocoee Series in the Knoxville quadrangle (Keith, 1895). In his definition of the Cades, Keith $(1895$, p. 2) noted its occurrence northwest of the main mountain range in the vicinity of Cades Cove, part of the area in which the unit is now recognized; however, the distribution and stratigraphy of the Cades shown by Keith are different from those of the present report.

The Cades Sandstone underlies the mountainous area northwest of the main range of the Great Smoky Mountains between the Little Tennessee River and Cades Cove and forms the crest of Rich Mountain north of Cades Cove. Its extent west of the Little Tennessee River has not been mapped. The narrow outcrop belt of Rich Mountain extends eastward beyond the limits of plate 2 for about 1 mile to its termination in Spence Branch in the southwest corner of the Wear Cove quadrangle (King, 1964, pl. 4).

\section{DESCRIPTION}

The Cades is formed of dark-gray sandstone interbedded with dark-gray argillite and siltstone. Coarseand medium-grain sizes dominate in the sandstones, 
but granule conglomerates are abundant, and there are a few boulder conglomerates. Graded beds 1-4 feet thick are characteristic of the Cades; these beds grade from granule conglomerates at the base through coarse and medium-grained sandstone to fine-grained parts above. Composite graded beds with coarser

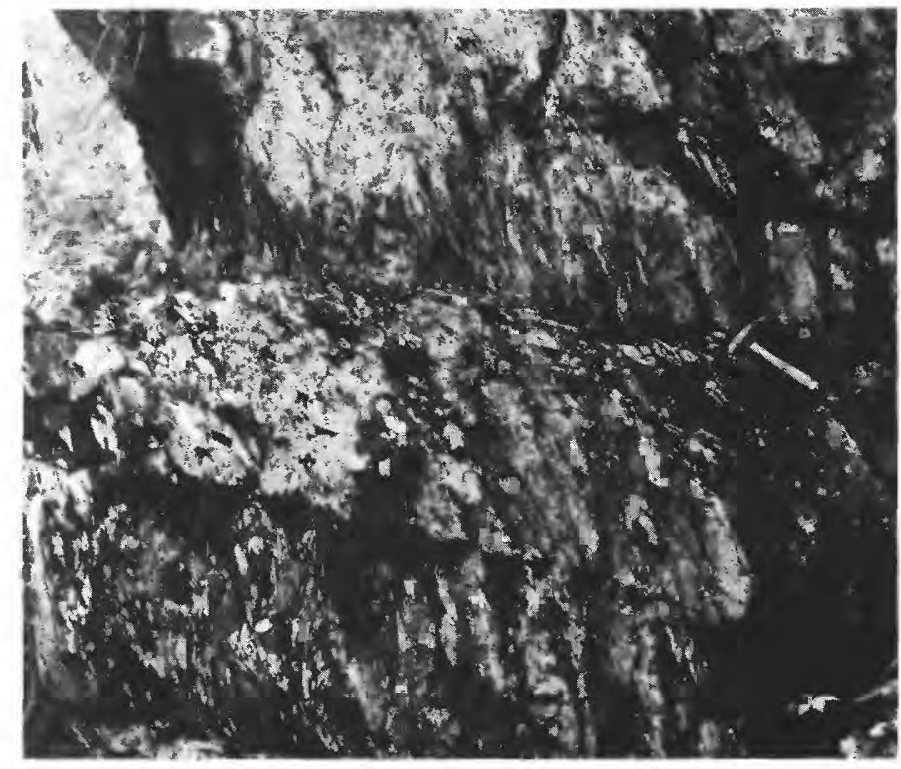

A. Cleaved sandstone at Abrams Falls. Beds dip gently southeast and cleavage dips steeply southeast; graded bedding, not visible, confirms that beds are right way up. Photograph by Warren Hamilton.

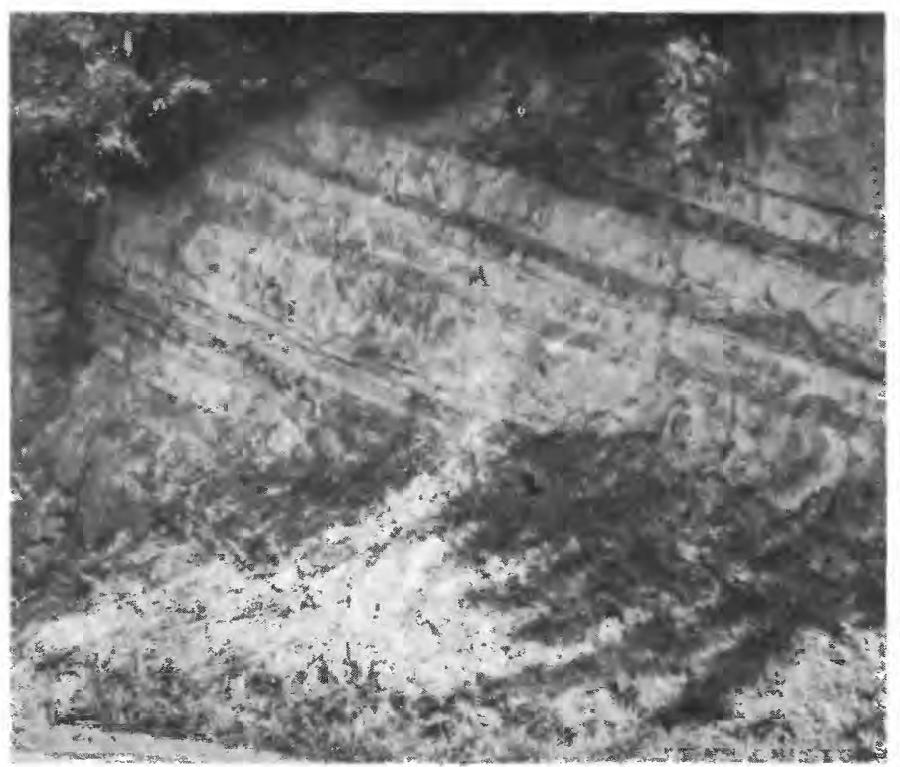

C. Saprolite. Sandstone is light colored; argillite is dark. U.S. Highway 129, 1 mile east of Calderwood. sandstones in contact with finer, without intervening argillaceous layers, are much less common in the Cades than in the Elkmont. Most beds in the Cades are thinner than those in the Elkmont, and graded layers as little as a few inches thick form persistent stripes across the face of many exposures (fig. $3 C$ ).

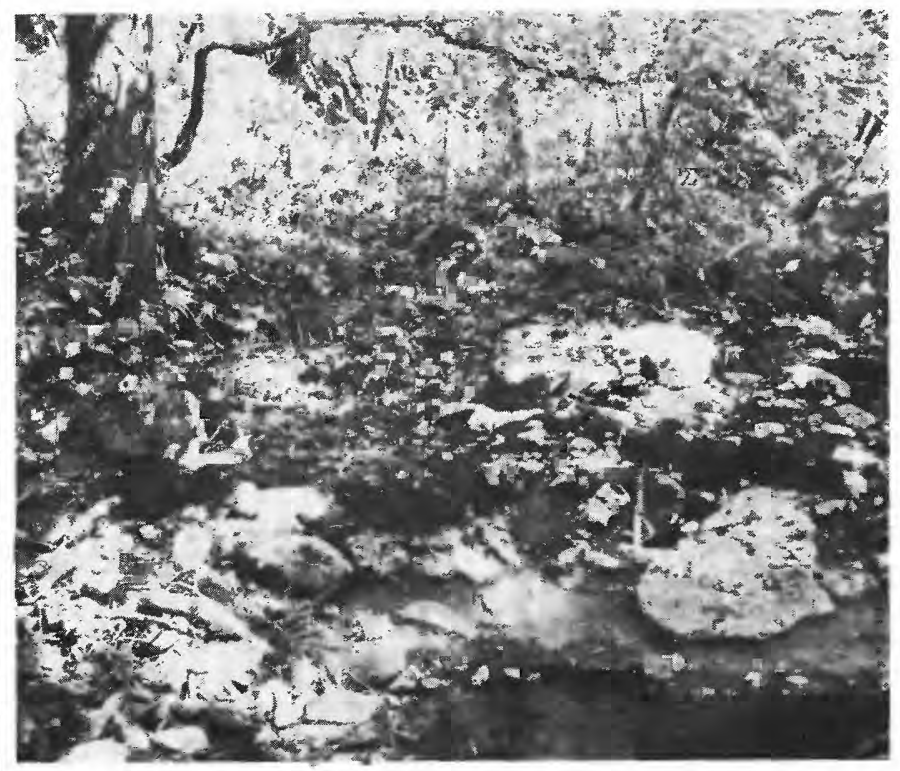

B. Boulder conglomerate. Panther Creek, about 1650-foot contour. Beds dip $50^{\circ} \mathrm{SE}$, away from the camera.

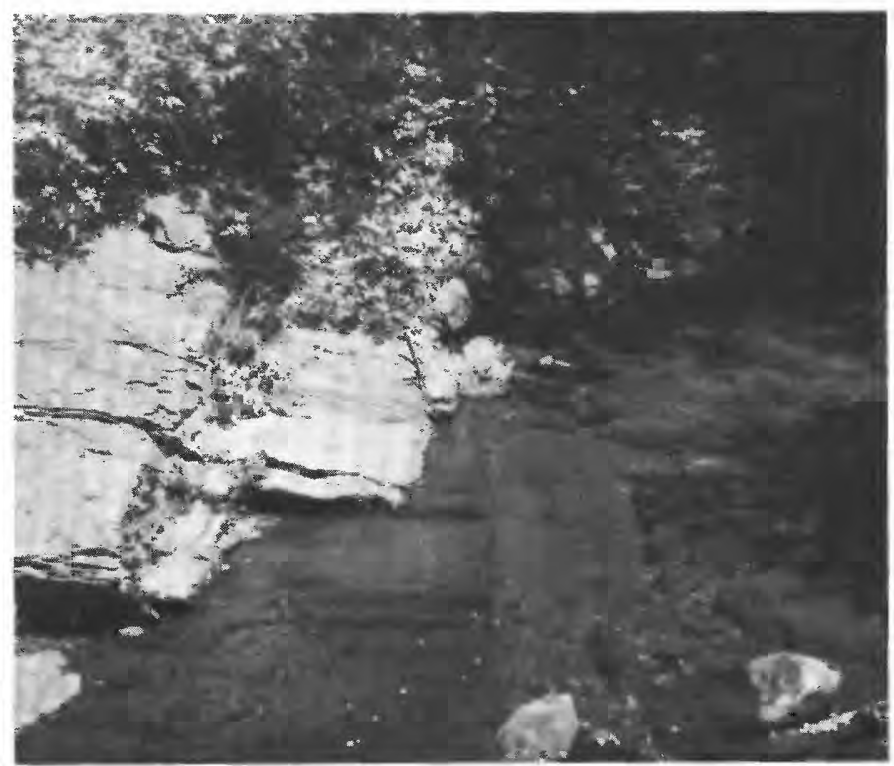

D. Argillite. Bark Camp Run, 500 feet southeast of its mouth (Kinzel Springs quadrangle). Overturned bedding dips steeply southeast (right), parallel to hammer handle; cleavage dips gently southeast. 
Sandstones of the Cades have a wider range of grain size and more fine-grained matrix than those of the Elkmont. They also contain fragments of granitic rocks, which are rare in the Elkmont, and pieces of dark shaly rock are more abundant in the Cades. Sandstones of the Cades would therefore be classed as graywackes by most geologists.

As much as a third of the volume of the sandstones is micaceous matrix. Quartz is the most abundant mineral of the sand fraction, but as much as 30 percent of this fraction is feldspar. Megascopically, the quartz is clear, milky, or smoky-gray, but none of it is distinotly blue like that of the Elkmont. In thin section the quartz shows strain shadows; some larger grains have been cataclastically smeared and recrystallized into lenticular mosaics whose long dimensions are parallel to the rock cleavage. Microcline and albite occur in about equal amounts, in sizes comparable to the associated quartz but more nearly equidimensional. Both enclose sericite and other alteration products. Fragments of pegmatite, perthite, quartzite, argillite, and siltstone are minor but conspicuous constituents. The latter two, obviously derived from penecontemporaneous deposits, range in size from microscopic chips to large distorted masses.

The micaceous matrix of the sandstone, like the interbedded argillite of the formation, consists of sericite, chlorite, and small amounts of biotite. The orientation of these minerals and of the elongated quartz mosaics produce the fracture cleavage (fig. $3 A$ ); the quality of the cleavage depends on the amount of matrix present. Fine-grained biotite, commonly in clusters, occurs with chlorite in about half of the specimens studied. Calcite is present throughout the sandstone, and in a few places as much as one-fourth of the rock is formed of it, apparently replacing feldspar and quartz.

The heavy-mineral suite of the Cades Sandstone is not significantly different from that of the Elkmont (Carroll and others, 1957 , p. 180). Ilmenite (and anatase derived from the weathering of ilmenite) and zircon dominate. The varieties of zircon and tourmaline in the Cades are the same as those in the Elkmont, and occur in similar proportions (Carroll and others, 1957, p. 183).

Boulder conglomerate that forms a small part of the formation contains pebbles, cobbles, and boulders of quartzite, gneiss, and granitic rocks as much as 20 inches across (fig. $3 B$ ). Few of the larger fragments are in contact with one another; they seem to be suspended in a matrix of coarse sandstone. Rounding ranges from good to poor, but few are spherical, and equidimensional particles are rare. Their long dimen- sions are commonly parallel to bedding. Conglomerate beds are crudely graded, with large fragments most abundant at the bases. Both the abundance and size of fragments decrease in higher parts of conglomeratic beds. Some beds $5-15$ feet thick are conglomeratic throughout, and conglomeratic sequences are much as 50 feet thick. Shallow parallel striations resembling slickensides on some cobbles and boulders are probably of tectonic origin.

Dark-colored fine-grained rock, including argillite, slate, and siltstone, is interbedded with sandstone of the Cades and in some places forms units of considerable thickness. Such rock forms a belt about 2,000 feet wide and 4 miles long in the Kinzel Springs quadrangle, and units as thick as 500 feet were found at several places but were not mapped separately.

These fine-grained rocks are darker and apparently more carbonaceous than similar rock of the Elkmont and Wilhite Formations. As in these formations, the finer the grain, the darker the color. Laminations are caused by minor variations of grain size and vary accordingly in color. Laminae are spaced as closely as $\mathbf{1}$ per millimeter; only the coarse siltstones are without laminae. Laminae are parallel and constant in thickness across an outcrop. Variations in texture range from argillite and slate, in which most grains are too small to be distinguished with a hand lens, through siltstone, to dark-colored fine- to medium-grained sandstone in nonlaminated beds $2-8$ inches thick. This sandstone has a much higher proportion of finegrained matrix to detritus than the common sandstones of the formation, and it appears to grade upward into argillite by decrease in the amount of larger detritus. The argillite, most of which is slaty, is composed of oriented sericite, chlorite, and biotite in various proportions with an average grain size of about 0.01 by $0.05 \mathrm{~mm}$. Disseminated carbon and pyrite are sufficiently abundant to make many thin sections nearly opaque. A few clastic grains of quartz and feldspar as much as half a millimeter in diameter are scattered through almost all of this fine-grained rock.

$$
\text { WEATHERING FEATURES }
$$

The Cades resembles the Elkmont in general appearance and topographic expression but forms somewhat lower mountainous country. It is best exposed in stream valleys where some of the more prominent sandstone beds form waterfalls, such as Abrams Falls in Abrams Creek. Like the Elkmont, the Cades has weathered to saprolite and is seldom exposed along ridge crests.

The soils developed from the Cades have been used very little for agriculture, primarily because steep slopes form most of the outcrop area of the formation. 
Soils are thin on most slopes, or are disturbed by downhill creep; however, on ridge crests, profiles typical of gray-brown podzolic soils develop largely from saprolite. The soil is stony and contains fragments of weathered sandstone and argillite derived from bedrock below.

$$
\text { EXPOSED SECTIONS }
$$

Sections exposing thick sequences of the Cades occur at several places, but these sequences are structurally complex, and the beds dip steeply or are overturned. The best exposures are in streams which flow northwestward across the outcrop belt, especially in Panther, Abrams, and Hesse Creeks.

At the southwestern edge of the report area, on the Little Tennessee River, gently dipping coarse-grained sandstone projects in cliffs more than 200 feet above the powerhouse at Calderwood Dam. In accessible parts of the cliff, graded bedding indicates that the strata are overturned; some of the inverted graded units have granite pebbles at their bases. This inversion must be local, because in equivalent sandstone in weathered outcrops along U.S. Highway 129 a mile to the northeast, grading indicates that the beds are upright.

Along Panther Creek at least 3,000 feet of Cades is exposed. Next to the Rabbit Creek fault on the northwest is about 1,000 feet of dark argillite, underlain on the southeast by 50 feet of boulder conglomerate, followed, in turn, by sandstone and minor dark argillite. From here to the Oconaluftee fault, in a belt about 4,000 feet wide, the Cades is dominantly dark argillite; poor exposures and structural complexities obscure relations of these rocks to those on the northwest.

Along Abrams Creek, between Abrams Falls and Cades Cove, the Cades Sandstones dips at various angles southeastward. About 4,000 feet of beds seems to be preserved here between the Rabbit Creek and Great Smoky faults, although there might be duplication by undetected folds or faults. Graded bedding, cleavage, and other structures, where observable, indicate that tops of the beds are to the northwest and that much of the sequence is overturned.

Between the Rabbit Creek fault and Abrams Falls, a quarter of a mile to the northeast, sandstone and argillite are interbedded in about equal proportions; cleavage in the argillite indicates overturning of the beds. Abrams Falls itself is formed by coarse sandstone in 2- to 3-foot beds which dip gently southeast and apparently are not inverted; weathered outcrops on the trail nearby indicate that these apparently massive beds are foliated (fig. $3 A$ ). Southeast of the falls, the best exposures are on the trail above the creek, and the sequence is dominatly coarse sandstone interbedded with units of dark argillite a few inches to several hundred feet thick. A good trailside exposure of about 500 feet of section extends across the large meander neck 1 mile northwest of Cades Cove. About 75 percent of it is coarse sandstone, in 5- to 15 -foot beds, which contains abundant chips of argillite of variable sizes, and quartz and feldspar grains as much as $6 \mathrm{~mm}$ in diameter; some dark argillite units as much as 10 feet thick are interbedded. Grading in the sandstone and cleavage in the argillite indicate that tops of the beds are to the northwest. Similar rocks are again well exposed along the trail for half a mile west of Cades Cove, but the larger grains are conspicuously flattened parallel to the bedding. Here the beds are again overturned, some more than $180^{\circ}$.

In Hesse Creek and its tributaries (pl. 3) the trace of the Rabbit Creek fault lies along the southeast slope of Beard Cane Mountain, and the highest, northwesternmost exposures of the Cades near Hogan Hollow are dark argillites and siltstones underlain by conglomerate, here 18 feet thick, and which, in turn is underlain by about 3,000 feet of sandstone and minor argillite. A second argillite unit and a second conglomerate beneath it are best exposed in Bark Camp Run and on the north slope of Cades Cove Mountain. The lower southeastern conglomerate on Hesse Creek may be the same as the one near the top of the section in Panther Creek.

STRATIGRAPHIC RELATIONS

The Cades is faulted against most of the formations with which it is in contact. The Rabbit Creek fault on the northwest separates it from Wilhite Formation, and the Oconaluftee fault on the southeast separates it from the Elkmont. The Cades is also in contact with Ordovician rocks along the Great Smoky fault for parts of the circumferences of Tuckaleechee and Cades Coves. South of Tuckaleechee Cove the Cades is also faulted over one of the slices of Metcalf Phyllite.

Unlike the contacts of the Cades with the formations just mentioned, the contact with the Metcalf Phyllite seems more likely to be sedimentary than tectonic in most places. This contact is well exposed on the slope of Cades Cove Mountain north of Cades Cove and in two belts south and southwest of the cove. At all these places the contact dips steeply southeastward and is abrupt and clean cut, without gradation from one formation to the other, yet with little indication of structural disturbance. Grading of the sandstone beds of the Cades adjacent to the contact provides indication of the tops of the beds, but similar features cannot be seen in the Metcalf Phyllite.

In the exposures of the contact north of the cove and in the northern of the two belts south of the cove, 
tops of the beds in the Cades face away from the contact, suggesting that the Cades overlies the Metcalf. The clearest of these exposures is on Mill Creek, nearly a mile southeast of elevation point 1710 . Here, sandstone beds of the Cades for several hundred feet northwest of the contact dip $30^{\circ}-40^{\circ}$ southeast; nearly every bed is graded and indicates an overturned succession. The sandstones show little internal deformation, except for elongation of quartz grains down the dip. Metcalf Phyllite lies with sharp contact against the southeasternmost sandstone bed, the first 4 feet being intensely crumpled and the bedding obliterated. Beyond, thin sandy laminae in the phyllite indicate its bedding, which is parallel to that of the Cades. Foliation in the phyllite is parallel to the bedding and is crenulated along axes parallel to the elongation of the quartz grains in the adjacent sandstone.

In the southern belt, which passes through Whistling Gap, south and southwest of Cades Cove, the contact is also well exposed in several places. Here it is as abrupt as in the belts to the north, and bedding in the Metcalf is also parallel to that of the Cades; here, however, grading of the sandstone beds in the Cades indicates that tops are to the southeast, toward the Metcalf. This contact is followed by a pronounced topographic lineament, suggestive of faulting.

The meaning of these contacts and the conflicting relations between the northern and southern belts are not entirely clear. If the contacts in one or both belts are faulted, there is little indication of it, and if they are faulted, the magnitude of the faulting is indeterminable; a certain amount of movement between two units of such different competence is to be expected, even if they were once in sedimentary contact. If the contacts are sedimentary, they suggest that the Cades and the Metcalf intertongue in such a manner that either formation might overlie the other from place to place. The possibility that the contact is sedimentary is strengthened by the sedimentary superposition of the sandstones like the Cades over the Pigeon Siltstone on the south slope of Webb Mountain, east of the report area (Hamilton 1961, p. 17), in an area where stratigraphic relations are less obscured by structure.

\section{WALDEN CREEK GROUP}

The Walden Creek Group is a body of argillite, siltstone, feldspathic sandstone, conglomerate, and limestone which crops out in the northern foothills of the Great Smoky Mountains (King and others 1958, p. 961). The group includes rocks mapped by Keith (1895) as Wilhite Slate, Pigeon Slate, and Citico Conglomerate in the northern foothills; it thus corresponds approximately to the Hiwassee Slate of
Keith's $(1904,1907)$ later classification of the Ocoee Series. The name was taken from Walden Creek in the Walden Creek quadrangle (King 1964, p. 45).

The following formations of the Walden Creek Group were named in the Richardson Cove and Jones Cove quadrangles (Hamilton, 1961, p. 18-27) and have been traced into the type area of the group (King, 1964).

Sandsuck Formation: Siltstone, fine to coarse-grained sandstone, and conglomerate.

Wilhite Formation: Siltstone with abundant carbonate, limestone, and fine- to medium-grained sandstone.

Shields Formation: Largely conglomerate and sandstone. Licklog Formation: Noncalcareous siltstone and sandstone. Base unknown.

In the present report area the Sandsuck and Wilhite Formations are extensive, a small body of rocks is questionably assigned to the Licklog Formation, and a faulted block of conglomerate assigned to the Wilhite may be equivalent to the Shields.

\section{LICKLOG(?) FORMATION}

The Licklog(?) Formation is exposed only at the eastern edge of the report area, at the western end of a belt of outcrop which extends eastward along the north side of Tuckaleechee Cove in the Wear Cove quadrangle (King, 1964, pl. 4). Several units of phyllite and sandstone, about a thousand feet thick, are preserved here above the Great Smoky fault.

A lower unit of fine- to medium-grained sandstone forms prominent ledges around Alie Mountain within the report area and on other ridges farther east. It is underlain, next to the Great Smoky fault, by strongly foliated greenish-gray phyllite. This phyllite contains a few thin beds of pellety limestone like those described below in the Wilhite Formation. Above the lower sandstone is another unit of phyllite, darker than that beneath, which is followed by a higher sandstone unit. This sandstone is somewhat coarser than that of the lower unit and grades into the conglomeratic beds of the Shields Formation, which are preserved above it in the Wear Cove quadrangle east of the report area.

\section{WILHITE FORMATION}

The Wilhite Formation is named for Wilhite Creek in the Richardson Cove and Jones Cove quadrangles east of the report area (King and others, 1958, p. 962). The name is adapted from the Wilhite Slate of Keith $(1895$, p. 2$)$, but with very different interpretation of the sequence and structural relations. In the type area the unit as now defined lies on coarse-grained rocks of the Shields Formation and is overlain by siltstone of the Sandsuck Formation. Here it is divisible into a lower or Dixon Mountain Member of calcareous siltstone with some interbedded sandstone, and an upper 
or Yellow Breeches Member of argillaceous, silty, and sandy rocks containing many units of sandy and conglomeratic limestone (King and others, 1958, p. 962; Hamilton, 1961, p. 21-26).

Silty rocks like those of the Dixon Mountain Member extend with only a few gaps from the type area into the present report area, but rocks like the Yellow Breeches Member pinch out east of the border of the report area (King, 1964).

Within the report area the Wilhite Formation consists of two rock assemblages. The main body is largely gray calcareous siltstone. Interbedded with this in part, but in part forming a large separate mass, is quartz pebble conglomerate and quartzose sandstone interbedded with siltstone that is much darker than that of the "main body; the bodies of sandstone and conglomerate are distinguished separately as unnamed members of the Wilhite Formation. The siltstone of the main body may be as much as 10,000 feet thick, and some of the conglomerate members are as much as 2,500 feet thick.

The sandstone and conglomerate units of the present report area, and elsewhere in the belt of outcrop of the Walden Creek Group, were termed the Citico Conglomerate by Keith $(1895$, p. 2), but these occur at several levels in the group and in several formations. The type Citico, across the Little Tennessee River southwest of the report area, is interbedded with siltstone here classed as Wilhite; but the Shields Formation east of the report area, composed largely of similar rocks, underlies the Wilhite. The name Citico is therefore no longer used for these sandstone and conglomerate units.

\section{IITHOLOGIC FEATURES}

The main body of the Wilhite Formation is the dominantly siltstone, argillite, and fine sandstone that locally contains beds of coarser sandstone, conglomerate, and carbonate rocks. The coarse-grained rocks are like those of the conglomerate members described below.

The siltstone is generally medium gray, but in places is greenish gray or maroon. Gray and greenish-gray rocks intergrade, whereas maroon siltstone forms welldefined beds 4- 8 feet thick, characteristically associated with rocks of strong green hue. Conspicuous bedding partings 1-3 feet apart are coated with flakes of detrital mica. Between these partings are parallel to gently undulating laminations, one to several millimeters thick, consisting of alternations of siltstone and darker argillite, generally in graded sets.

Rusty seams on many outcrop faces of the Wilhite are caused by weathering of iron-bearing carbonate in the thin layers of coarse-grained siltstone and fine- grained sandstone that commonly form the base of these graded sets. The sandstone at the base of these graded units is nearly massive and without laminae; upward argillaceous partings appear, becoming more abundant and thicker, finally grading into the more common laminated argillite. Laminae in a few sandstones that are not part of graded sets are intricately contorted and convoluted.

Cleavage is more conspicuous than bedding laminations in most places, especially in the rocks of more uniform texture. The better cleaved rock was worked in places for roofing slate. The largest quarry is about 1 mile east of Chilhowee, but there are several others along Panther Creek and other streams that join the Little River south of Abrams Creek. In most of these quarries slaty cleavage parallels bedding laminations, and even-surfaced uniform-colored slabs were easily obtained. Where cleavage and bedding intersect at large angles, they form partings of about equal strength, and the rock breaks into peg-shaped fragments rather than slabs (fig. $4 A$ ).

The argillite and slate consist of as much as 90 percent micaceous minerals, with quartzose silt in minor amounts. Chlorite and sericite occur in about equal amounts, in crystals about 0.005 by $0.03 \mathrm{~mm}$ in size. Where slaty cleavage is weak, these crystals are randomly oriented; where the cleavage is better developed, they become better oriented. Where strongest, cleavage folia are about 0.01 thick and $0.02-0.2 \mathrm{~mm}$ apart. At least 10 percent of the more argillaceous rocks and as much as 70 percent of the siltstones are formed of angular quartz grains $0.05-0.2 \mathrm{~mm}$ in diameter. Disseminated crystals of iron-bearing calcite, $0.05-0.2 \mathrm{~mm}$ in diameter cement the siltstone. Penninite, pyrite, and finely divided carbon are also present in small amounts.

The conglomeratic units of the Wilhite Formation consist of conspicuous beds of conglomerate lying in or grading into sandstone, and both are interbedded with siltstone, argillite, and a few beds of limestone.

Beds of conglomerate are a few inches to about 10 feet thick. Many conglomerate beds, as thick as 6 feet, are massive and without apparent gradation from bottom to top; others are distinctly graded from conglomerate below into pebble-free sandstone, and a few layers are directly overlain by dark argillite. Contacts between beds are sharp. Many bedding surfaces are undulatory over an eroded or scoured surface, and a few are complex intertongues of sandstone and conglomerate (fig. $3 B$ ).

Most pebbles in the conglomerate are about an inch in diameter, well rounded, and nearly spherical, but size, shape, and sphericity vary widely. In some beds, 
pebbles of different sizes are closely packed and in contact with each other, with the interstices filled with coarse-grained sandstone. In others, most pebbles are separated by the coarse-grained sandstone matrix.

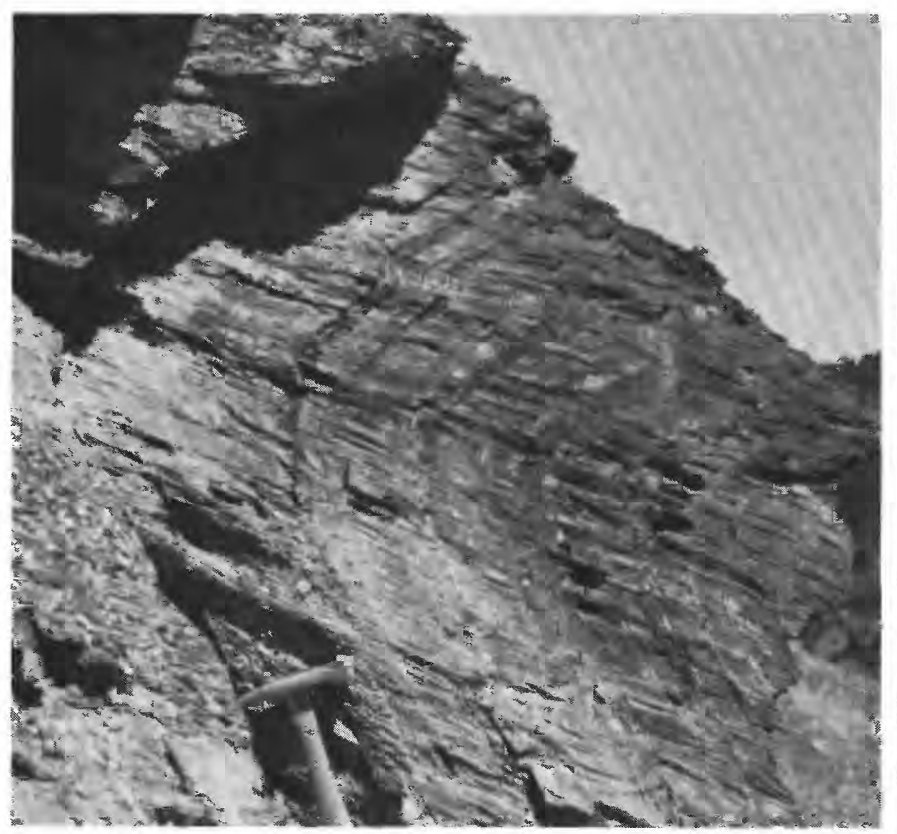

A. "Iron-banded siltstone." Dark bands are siltstone with carbonate cement, interbedded with noncalcareous slate. Beds face northwest; cleavage dips gently southeast. Half a mile west of Chilhowee Post Office.

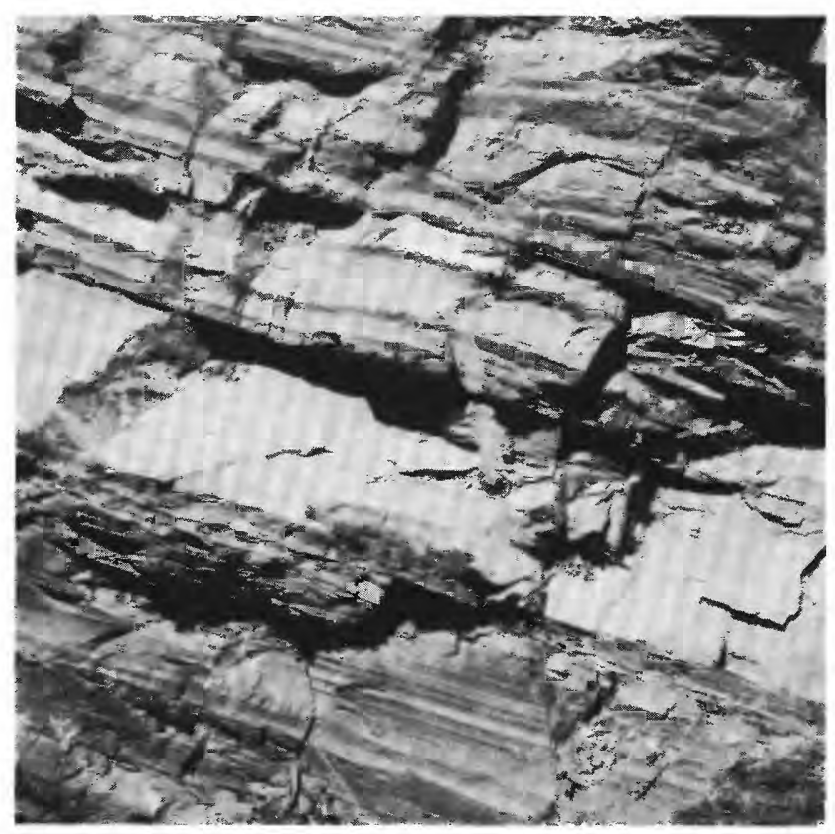

C. Argillite and fine-grained sandstone interbedded in coarse-grained Wilhite Formation. Figure 5 shows details of a specimen from this sequence. Same locality as $B$. Photograph by Warren Hamilton.
Flatter pebbles lie upon one another in imbricate fashion.

Pebbles and rock fragments of two kinds occur. The common well-rounded ones were derived from a crystal-

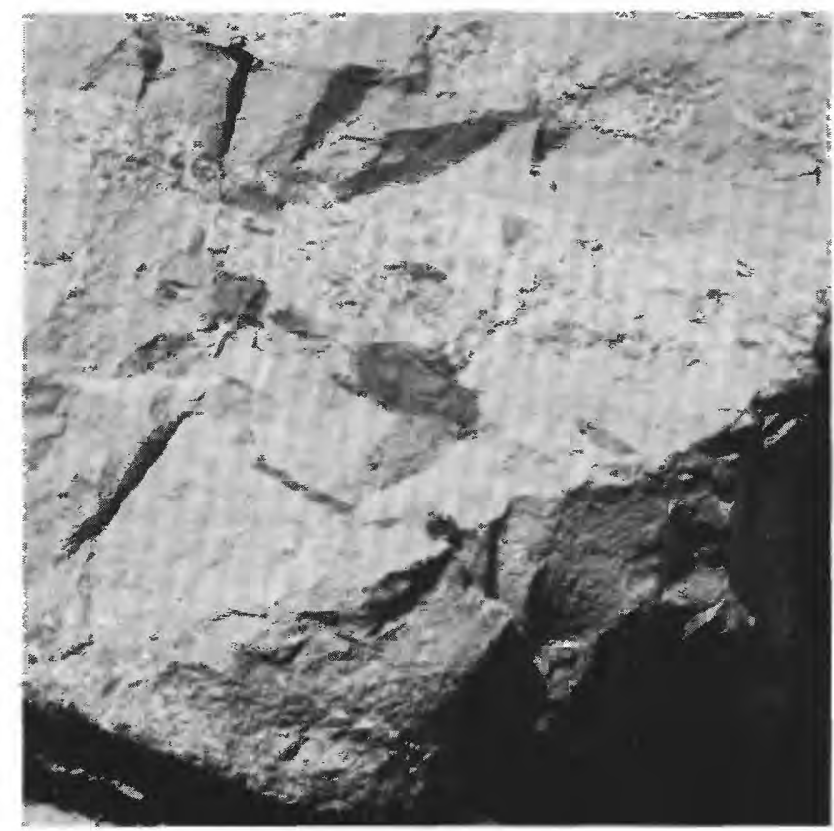

$B$. Interbedded conglomerate and sandstone. Much of the conglomerate is lenticular, and its fragments are crudely imbricated, oversteepened to the northeast (right). Tennessee Highway 73, half a mile north of Kinzel Springs. Photograph by Warren Hamilton.

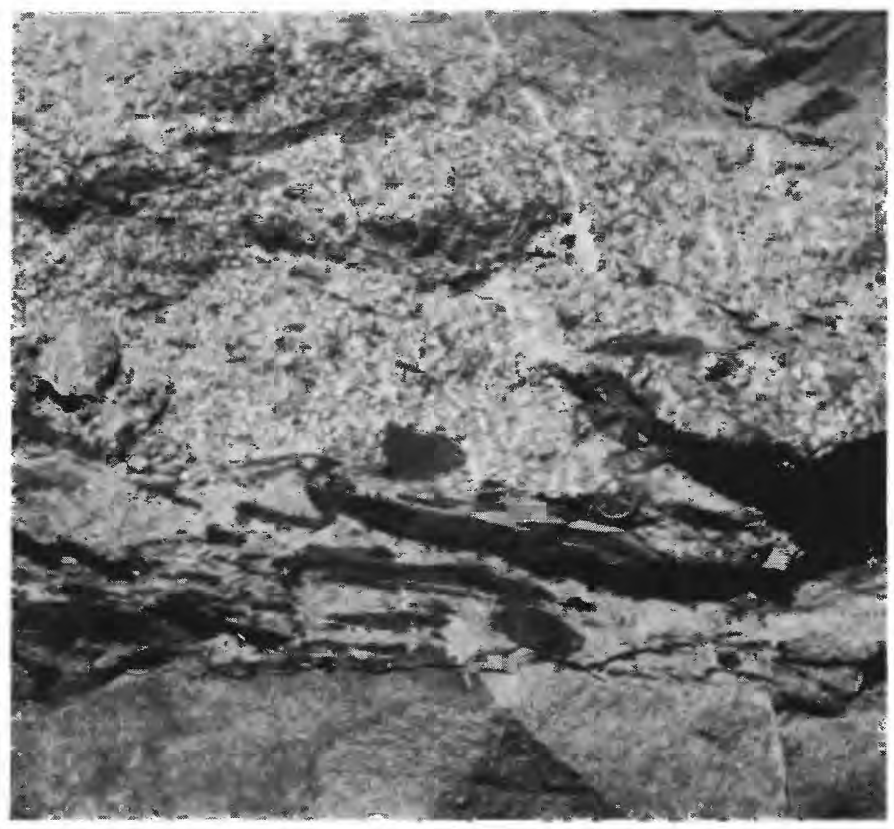

D. Flat pebble conglomerate beneath coarse roundstone conglomerate. Same locality as $\boldsymbol{B}$. Photograph by Warren Hamilton. 
line source, but angular fragments of sedimentary rock like those of the Wilhite are also abundant (fig. $3 D$ ). Of the fragments of crystalline origin, 80 percent are milky vein quartz, as much as 10 percent are of large feldspar crystals, 5 percent are vitreous quartzite, and minor amounts are fine-grained chlorite-rich siltstone resembling chert, and pegmatitic granite. Angular fragments of dark argillite and siltstone like those interbedded with conglomerate are abundant in both pebble conglomerate and associated sandstone. These fragments range in size from small chips to contorted masses several feet in maximum dimension. In a few beds they are the only rock fragments present, here forming as much as 20 percent of the rock. Coarsegrained sandstone, dolomite, and limestone also occur as angular to rounded fragments in the conglomerate.

The largest fragment seen in a boulder of calcareous coarse-grained sandstone, 5 feet long and 3 feet wide, lying in a rubbly coarse-grained bed in the floor of the creek in Middleset Hollow (northeast corner of Kinzel Spings quadrangle, pl. 3). This bed contains several similar sandstone boulders about a foot in diameter and a cobble of vitreous quartzite 6 inches in diameter. These boulders lie in a matrix consisting of quartz pebbles an inch in diameter and carbonate-bearing coarsegrained feldspathic sandstone.

Sandstones of the Wilhite Formation are less feldspathic than those of the Elkmont and Cades previously described, and most of them are cemented with carbonate rather than with interstitial micaceous material. Few sandstones of the Wilhite would therefore be classed as graywacke. Grains and pebbles are better rounded, and, unlike the uniform beds of the Cades and Elkmont, those of the Wilhite are highly variable, with sandstone and conglomerate intricately mixed.

Sandstones occur with conglomerates as the finer parts of graded beds, as individual beds which contain small lenses of conglomerate, and as conglomerate matrix. Such sandstones are light gray to gray where fresh, but their exposed surfaces are iron stained. They are composed of rounded grains of quartz, feldspar, and quartzite $0.03-2 \mathrm{~mm}$ in diameter and a few shreds of muscovite, set in a carbonate matrix. The quartz is clear, milky, to light bluish gray, in subrounded grains, all of which show undulatory extinction. Most grains retain their original outlines, but those in close contact are intergrown. Less than 10 percent of the rock is feldspar, and slightly altered microcline is somewhat more abundant than albite. The iron-rich carbonate of the matrix constitutes as much as 40 percent of the rock, but generally much less. The maroon sandstones near the base of the Little River section contain small amounts of disseminated hematite.
The sandstones interbedded with dark fine-grained siltstones and argillites are darker than those associated with conglomerate and have as much as 20 percent micaceous matrix. Most of these rocks are distinctly graded, but from an increase in amount of argillaceous material upward rather than from a decrease in size of the detrital grains.

Dark-gray thin-bedded argillite and siltstone is commonly interbedded with the conglomeratic units of the Wilhite Formation, (fig. $3 \mathrm{C}$ ), forming units that range in thickness from thin partings between sandstone and conglomerate beds to units of mappable dimensions. Some of the thicker units are uniform sequences of laminated argillite and siltstone, but others contain interlayered fine- to medium-grained light-gray sandstone. The more uniform sequences have fine varvelike alternations of siltstone and more argillaceous rock 1-4 mm thick, in which the finer grained more argillaceous rock forms the darker parts. Graded bedding is more conspicuous where sandstone forms the base of graded sets 1-4 inches thick. Most of the sandstone is fine grained and well laminated, and all of it is distinctly lighter colored than the argillite or siltstone. Weathering accentuates bedding structures in these rocks, the coarser layers weathering most rapidly, increasing their contrast with the finer grained ones that retain their dark color.

The complex interrelation between coarser and finer grained materials are well illustrated by a specimen (fig. 5) collected from a fine-grained unit interbedded with conglomerate. The dark fine-grained layers, A-1 to $A-3$, each about 1 inch thick, are separated by thicker layers, $\mathrm{S}-1$ to $\mathrm{S}-4$, of fine-grained sandstone. Tops of beds are indicated by three features: (1) truncation of foreset beds, particularly in the upper part of layer $\mathrm{S}-4$; (2) gradation of grain size from a maximum at the base of layer $\mathrm{S}-4$; and (3) load-casting of layers A-1 and A-3. Consistent inclination of foreset beds in the sandstone layers and asymmetrical whispy attenuations of argillite into the sandstone indicate lateral movement of bottom currents and unconsolidated sediment from left to right (Kuenen, 1953, p. 1058). Translated into compass direction after restoring the specimen to its original horizontal position, these lateral movements were from a northern quadrant.

At many places carbonate rocks form layers, a few inches to 150 feet thick, in association with both siltstone and conglomerate of the Wilhite Formation. Limestone breccia occurs at a few places, and a few fragments of limestone and dolomite occur in some conglomerate beds. The most common carbonate rock is fine-grained and light- to dark-gray limestone. Light-colored limestone, commonly well laminated, is 


\section{D18}

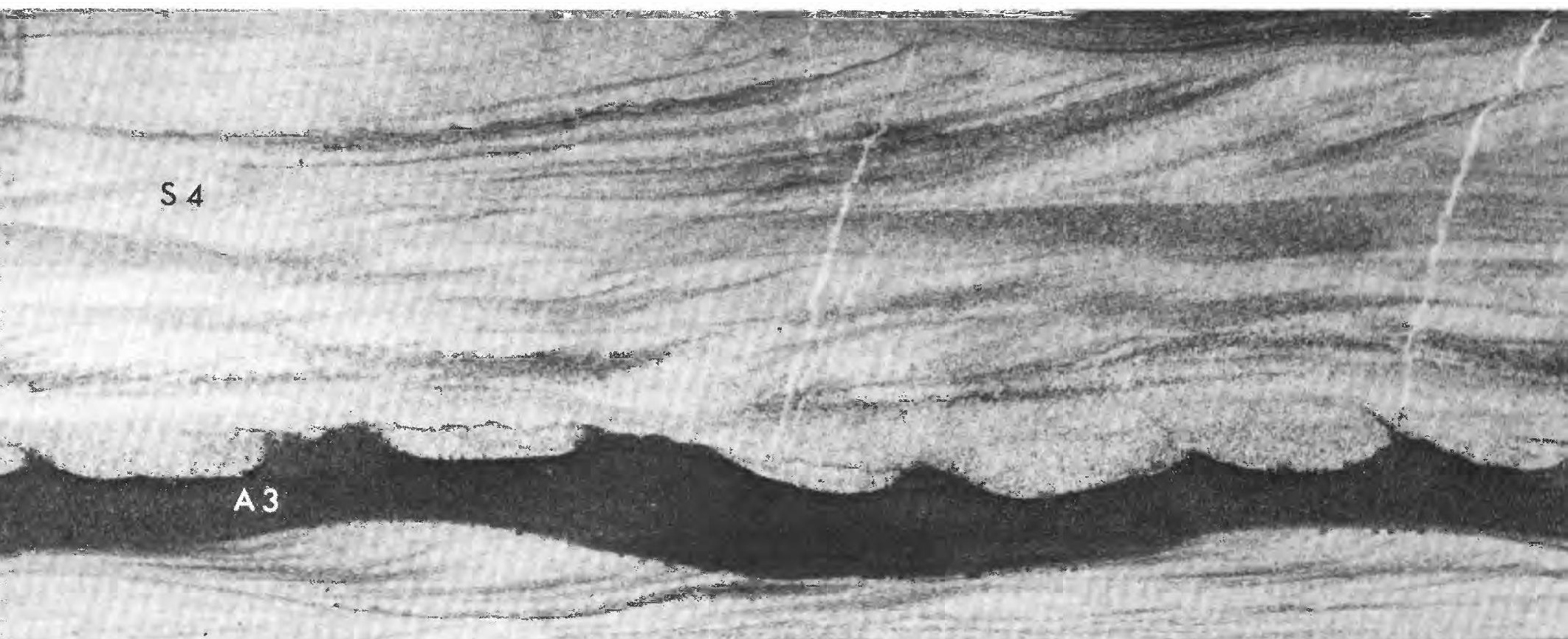

\section{S 3}

\section{$A^{2}$ ?}

\section{2}

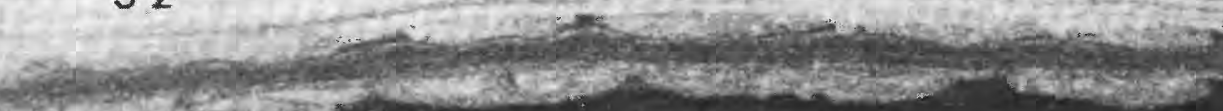

Wherew

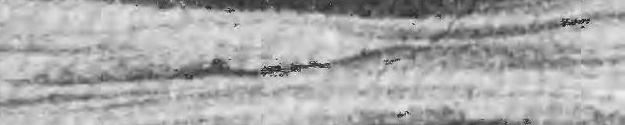
(a) 
interbedded with light-colored siltstone, and the darker limestone is associated with conglomerate.

Many limestone beds are uniformly fine-grained, but others contain small clusters of calcite crystals, quartz grains, or spherules of chlorite. Laminations at 1-5 $\mathrm{mm}$ intervals reflect small changes in silt content and are nearly parallel; no cross-laminations were seen. More pronounced beds of laminated and nonlaminated limestone 1-6 inches thick in some places are crossed by vertical septa of silty limestone $2-4$ inches apart and $1 / 2-1$ inch wide. These resemble "pull-apart" structures described by Natland and Kuenen (1951, p. 89-90), which they ascribe to submarine slump of soft sediments. East of Tallassee (pl. 2), beds of silty limestone several inches thick are contorted into small asymmetrical folds that were probably formed by processes related to those which formed the pull-apart structure (Natland and Kuenen, 1951, p. 90-92).

Limestone breccias, possibly of related origin, have angular fragments from a fraction of an inch to 12 inches in average dimension, which contain two or more varieties of limestone. Some of the fragments are closely packed, with little matrix, but others appear to float in sandy limestone. These breccias were noted by Safford (1869, p. 188-189) and Keith (1895, p. 2) who reported their former use as ornamental stone.

Spherical bodies of two kinds that occur in limestones of the Wilhite are of special interest. Concentrically laminated ooliths and pisoliths, $0.2-5.0 \mathrm{~mm}$ in diameter, that form distinct beds in some places may have been formed by inorganic processes or by algae (Rezak, written commun., 1953) ; no other structure in the Ocoee Series is more suggestive of biologic origin. Other spherical bodies 1-1.5 mm in diameter are radial clusters of muscovite around quartz nuclei (Mrose, written commun., 1961).

\section{WEATHERING FEATURES}

The Wilhite Formation in the report area forms an intricately dissected topography with relief of about 500 feet, but some sandstone and conglomerate units project in higher ridges. Resistant beds, especially the sandstones and conglomerates, form strike ridges that reflect structural trends. The Wilhite Formation is well exposed along streams, many of which afford nearly continuous sequences. Exposures are somewhat sparser on the slopes and ridge crests, although the conglomerate and sandstone form prominent crags and bluffs in places, and the finer grained rocks project in many ledges.

Soils developed from the siltstones are thin and easily eroded, but they are commonly farmed. The upper zones of the soil profile have long been eroded away, however, and crops are rooted in weathered stony parent materials. The soil formed from dark siltstone and argillite associated with conglomerate units is distinctly lighter than that of the main body of siltstone which is generally yellow brown.

Solution of the carbonate cement of conglomerates and sandstones releases their detrital particles, and residual accumulations of these particles on gentle slopes and ridge crests look like sand and gravel deposits.

\section{EXPOSED SECTIONS}

The Wilhite Formation of the report area is separated into two parts by the Capshaw Branch fault. The rocks below this thrust fault are mainly siltstones of the main body of the Wilhite Formation that contain a few conglomerate units. The rocks above it are mostly conglomeratic; the original stratigraphic relations of the rocks separated by this fault are uncertain.

Two sequences representative of the Wilhite Formation beneath the Capshaw Branch fault and one sequence representative of the formation above the fault are described below.

The longest, thickest, and probably most complete sequence of the Wilhite Formation northwest of the Capshaw Branch fault extends for about $4 \frac{1}{2}$ miles along the Little Tennessee River from the northern margin of the Calderwood window northwestward to the Miller Cove fault (pl. 2). In this sequence most beds dip northwest or are overturned toward the southeast, so that virtually all beds face northwestward, with an upward sequence in that direction. (See structure section $A-A^{\prime}, \mathrm{pl} .2$ ). Intricate small-amplitude folds pervade the entire sequence, especially in the thinner bedded rocks, but no important faults were seen. The total thickness exposed is about 7,000 feet.

Many of the units that are distinctive in good exposures on the bluffs along the river lose their identity in the hills to the north, probably the result of both structural and stratigraphic complexities. On the geologic map (pl. 2), therefore, the Wilhite in the vicinity of the Little Tennessee River is subdivided into outcrop belts of alternating coarse- and fine-grained rocks, but these subdivisions could not be traced for many miles northeastward.

The oldest beds at the northern border of the Calderwood window are gray laminated siltstone and finegrained thin-bedded sandstone interbedded with medium- to coarse-grained sandstone in graded nonlaminated beds 6 inches to 1 foot thick; they have been thrown into sharp folds with nearly horizontal axial planes (fig. 14D). Above them to the north, a lower conglomeratic unit about 200 feet thick with quartzpebble conglomerate, feldspathic sandstone, and gray fine-grained limestone and limestone breccia crops out 
along the highway about 1.6 miles south-southeast of the mouth of Abrams Creek. A higher limestone bed crops out at the mouth of a hollow 500 feet to the north. The main siltstone body of the Wilhite Formation is exposed along U.S. Highway 129 from about 1.2 miles south-southeast of the mouth of Abrams Creek to the Chilhowee Post Office (mouth of Chilogatee Creek and beyond), and is about 4,000 feet thick. It is mostly gray “iron-banded' siltstone, but includes some good slate. The maroon and green slaty siltstones that were quarried at several places in Panther Creek lie in this part of the section.

West of the Chilhowee Post Office (pl. 2) the siltstone, well exposed in roadcuts, is gray without notable green or red colors, has a good slaty cleavage (fig. $4 A$ ), and includes 2 beds of limestone breccia each about 50 feet thick. Above this siltstone, about threequarters of a mile southwest of Chilhowee Post Office, the lowest of several conglomeratic units, about 150 feet thick, is exposed in new highway cuts. It is overlain by sandy, spherulitic, and brecciated limestone about 35 feet thick. Above the limestone is crumpled gray siltstone, forming a belt about 1,500 feet wide into which conglomerate and siltstone intertongue near the top, grading into a prominent conglomeratic unit 300 feet thick that crosses the Little Tennessee River at Stratton Shoals. This conglomerate is overlain by dark siltstone and fine-grained sandstone about 55 feet thick, grading upward into lighter colored greenish siltstone about 200 feet thick.

A third conglomeratic unit, on which Chilhowee Dam is located, forms a broad outcrop belt that extends westward along the river nearly to the mouth of Cochran Creek. The lower half of the unit contains some beds of exceptionally coarse rubble, with blocks of sandstone 10 inches in diameter, and slabs of argillaceous rock several feet long. The upper half contains a few layers of fine-grained thin-bedded limestone, much of which is complexly deformed. A thin bed of limestone at the top of the unit at the east side of the mouth of Cochran Creek is overlain by deeply weathered siltstone. In the hills north of the village of Tallassee, between Cochran Creek and the Miller Cove fault, the rocks are less well exposed, but are mostly interbedded conglomerate and siltstone.

The section along the Little River and in the mountains to the east of it ( $\mathrm{pl} .3$ ) contains about 4,000 feet of beds. Northwest of the Capshaw Branch fault the prevailing dip is southeast; the lowest beds are to the northwest, against the Miller Cove fault, and the highest beds lie in the Bates Mountain synclinorium. The thin-bedded rocks are more complexly folded than those of the Little Tennessee River section, so that thicknesses can only be approximated. The lowest beds, exposed on both sides of the river at the highway level, are maroon and gray sandstone, generally medium- to coarse-grained, but with some quartz pebbles as much as half an inch in diameter. They are overlain to the southeast, east, and northeast by a long sequence of monotonous fine-grained rocks mostly thinbedded gray siltstone, with subordinate greenish-gray and maroon siltstone, and a few thin light-gray dolomite beds. Faults and overturned folds in these rocks are common and are well displayed northwest of the mouth of Davis Branch on the southwest side of the river, in cuts of Tennessee Highway 73 (figs. $14 B$, $14 C, 16)$.

The rock in these exposures is characteristic siltstone of the main body of the Wilhite Formation with some interbedded argillite and fine sandstone forming graded layers $1 / 2-4$ inches thick. The fine sandstone contains discontinuous and irregular laminations or thin wisps of dark argillite and fine siltstone; a few show crossbedding, and some are enveloped in argillite as load casts.

Northeast of the Little River the siltstones strike and dip irregularly, and their structure is probably as complex as that in the exposures along the Little River. In the higher country to the east, however, the structure flattens into the broad east-plunging Bates Mountain synclinorium (pl. 3).

The Bates Mountain synclinorium is outlined by sandstone and conglomerate units interbedded and interfingered with the siltstone. A lower sandstone unit on the southeast slopes of Bates Mountain merges westward into sandy siltstones, but east of Webb Knob it forms a mappable unit of fine- to medium-grained nonconglomeratic sandstone as much as 150 feet thick, partly cemented by quartz and partly by carbonate. At the eastern edge of the Kinzel Springs quadrangle (pl. 3) it is seperated from a higher sandstone about 150 feet thick by about 400 feet of gray siltstone; but this intervening siltstone thins eastward, so that the two sandstones merge into a single unit about 1,000 feet thick in the Wear Cove quadrangle (King, 1964, pl. 4). Northwestward, across the synclinorium on Long Ridge, the sandstone changes into conglomerate that includes some coarse rubble beds like those described earlier in Middleset Hollow. Overlying this conglomerate and sandstone in the trough of the synclinorium, greenish-gray siltstones like those lower in the sequence are the highest beds preserved.

The upper plate of the Capshaw Branch fault is formed largely of conglomerate, best exposed along 
Tennessee Highway 73 of the Little River (pl. 3). The sequence is in two parts, separated by a high-angle reverse fault. Part of the southeastern segment is completely exposed in deep highway cuts, where conglomeratic rocks at least 200 feet thick form an orderly sequence (geologic section 1, below). Above the rocks of the measured section is about 200 feet more of conglomerate and sandstone, cut by a complex of faults. As much as 700 feet of interbedded conglomeratic and dark fine-grained rocks underlie the rocks of the measured section forming the outcrop belt that includes Kinzel Branch and Briar Branch, followed below by interbedded conglomerate, sandstone, and argillite that lie on the Capshaw Branch fault where it emerges on the southeast. The total thickness of rocks in the southeastern part of the upper plate of the Capshaw Branch fault is probably about 1,000 feet.

Geologic Section 1.-Part of the Wilhite Formation of the upper plate of the Capshaw Branch fault, exposed in roadcuts along Tennessee Highway 73 on the west side of the Little River, north of Kinzel Springs.

[Most of the section is in the deep cut about $1,300 \mathrm{ft}$ north of the mouth of Kinze Branch (pl. 3). Average strike about N. $45^{\circ}$ E., dip about $40^{\circ} \mathrm{NW}$.; cleavage visible only in fine-grained units 4,6, and 11, dips less steeply. For interpretation of struc

Unit Description

Thickness

Top of measured section is in deformed rocks near a fault of unknown displacement at the north end of the deep roadcut.

24. Slate-chip conglomerate; matrix is coarse-grained sandstone containing contorted and tabular fragments of argillite 1-15 in. long .............. . .

23. Sandstone with scattered pebbles.

22. Conglomerate, with abundant 1-in. pebbles and large slabs of slate.

21. Slate-chip conglomerate; matrix is coarse-grained sandstone with a few quartz pebbles..........

20. Sandstone, mostly coarse-grained, with scattered pebbles about $5 \mathrm{~mm}$ in diameter at base and scattered slate slabs as much as $10 \mathrm{in}$. thick and $2 \mathrm{ft}$ long .

19. Conglomerate: pebbles $15-20 \mathrm{~mm}$ average diameter, mostly quartz, with feldspar and dark metasiltstone less abundant. Basal layer contains boulder of sandstone $2 \mathrm{ft}$ in diameter and slate slab $7 \mathrm{ft}$ long and $1 \mathrm{ft}$ thick

18. Sandstone, medium- to coarse-grained, with scattered slate chips. Poorly defined bedding is marked by orientation of slate ships and small contrasts of grain size

17. Conglomerate and sandstone: conglomerate with rounded pebbles, dominantly quartz, composes about half of unit and forms 5 irregularly layered beds. Basal scour is apparent in some; graded bedding is visible in a conglomerate bed whose base is about $5 \mathrm{ft}$ beneath top of unit. ..........

16. Slate-chip conglomerate; matrix is coarse-grained sandstone with scattered rounded pebbles; thins updip _ _ 1-3

15. Sandstone, medium-grained, with a few dark-colored finer grained layers.
Unit

Description

Thickness

14. Conglomerate, massive; most pebbles about $10 \mathrm{~mm}$ in diameter; suggestions of imbricate arrangement; largest fragment is sandstone boulder about 20 in. in diameter; granitic pebbles common. Top of bed below is scoured, with relief of about $3 \mathrm{ft}$

13. Sandstone, medium- to coarse-grained, with scattered pebbles about $10 \mathrm{~mm}$ in diameter and small slate chips

12. Conglomerate in 5 beds alternating with sandstone; lowest conglomerate bed has a slate slab $2 \mathrm{ft}$ long

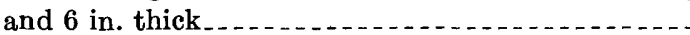

11. Siltstone, argillite and sandstone: dominantly dark siltstone interbedded with sandstone, displaying crossbedding and graded bedding (fig. $4 C$; for detail, fig. 5) . . .

10. Sandstone, coarse-grained; a few layers contain pebbles $5 \mathrm{~mm}$ in diameter..........

9. Sandstone, coarse-grained; largest grains $2-3 \mathrm{~mm}$ in diameter; basal layer with slabs and contorted masses of dark siltstone

8. Siltstone and argillite, dark-gray, finely laminated; 1 bed of gritty sandstone. . . . . . . . . . . . . . . .

7. Conglomerate and sandstone, interbedded in about equal proportions. Bedding poorly defined, with contrasting textures intimately interfingered: conglomerate layers from 2 in. to $8 \mathrm{ft}$ thick; slate chips abundant in 4 beds (fig. $4 B, D$ )

6. Siltstone, argillite, and sandstone, like unit 11 ; includes contorted sandstone bodies enclosed in dark siltstone (load casts)

5. Conglomerate and coarse-grained sandstone: bedding indistinct and not persistent; conglomerate includes sandstone boulder 12 in. long and 3 in. thick and other large cobbles and fragments of dolomite and

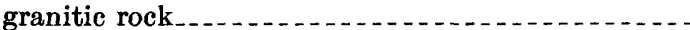

4. Siltstone, argillite, and sandstone, like units 6 and

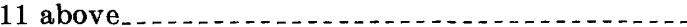

3. Conglomerate and coarse-grained sandstone, indistinctly bedded, in about equal amounts..........

2. Argillite and siltstone, like unit 4 above, but lacks sandstone -

1. Conglomerate and coarse-grained sandstone in about equal amounts; rubble bed about $6 \mathrm{ft}$ above base contains cobbles and boulders of sandstone, finegrained dolomite, and granitic rock ............ 21

Total about

Beds below are ash-gray laminated siltstone and argillite, presumably rock like that of units 4,6 and 11, but deeply weathered. Ends of folded beds terminate in a thin gouge zone at the base of unit 1 . The base of the section is therefore a fault, whose stratigraphic displacement is believed to be negligible.

Northwest of the high-angle reverse fault, the upper plate of the Capshaw Branch fault along the Little River consists of two units. The lower is a thinbedded sequence of alternating dark siltstone and lighter colored fine- to medium-grained sandstone, at least 200 feet thick, well exposed along the highway on the west side of the river. Its beds are thrown into folds that are truncated above by a bedding-plane fault $61 / 2$ at the base of the overlying thick-bedded conglomerate 
and sandstone. The latter form a northwest-dipping sequence, about 1,000 feet thick, that extends to the northwestern emergence of the Capshaw Branch fault. These conglomeratic rocks are like those of geologic section 1, except for greater weathering, and they probably duplicate at least part of that sequence.

Individual units of the upper plate of the Capshaw Branch fault, like those of the Little River section, were mapped in the Kinzel Springs quadrangle. Units southeast of the high-angle reverse fault are faulted off within 2 miles of the river, but those northwest of this fault extend for greater distances. The more northerly conglomeratic unit forms Beard Cane Mountain, but it was not identified southwest of Abrams Creek. It is apparently overlain by the dark argillite and siltstone, at least 200 feet thick, that crop out in the valley of Beard Cane Creek. This outcrop is followed on the northwest by another conglomeratic unit that crops out on Hatcher Mountain, and this in turn, by more heterogeneous rocks of Johns Ridge. In the southwestern part of the Kinzel Springs quadrangle, therefore, conglomerates and associated rocks of the upper plate of the Capshaw Branch fault may be as much as 3,000 feet thick. These subdivisions could not be mapped much beyond the Kinzel Springs quad. rangle, but together the associated conglomeratic and dark argillaceous rocks extend southwestward in a continuous belt from northeast of the Little River nearly to the Little Tennessee River.

The relations of the rocks of the upper plate of the Capshaw Branch fault with those of the lower plate cannot be established with assurance. They may be equivalent to the Shields Formation farther east and older than the Wilhite of the lower plate, or they may be equivalent to the upper conglomeratic part of the Wilhite of the lower plate. In its type locality the Shields consists of about 1,600 feet of conglomerate and sandstone, like the rocks of the upper plate of the Capshaw Branch fault in the report area. In his studies, Hamilton (1961, p. 20) found that the Shields was not persistent laterally and that similar rocks occurred at other levels in the Walden Creek Group. King $(1964$, pls. 2, 4), however, mapped two belts of Shields from near the type area nearly to the eastern boundary of the report area. On the other hand, there is more conglomerate in the upper part of the Wilhite Formation in the report area than farther east. The rocks of the upper plate of the Capshaw Branch fault are therefore as similar to those high in the Walden Creek Group in the report area as they are to those several thousand feet lower, and no means of assigning them with confidence to one or the other of these levels has been found.
STRATIGRAPHIC RELATIONS

The Wilhite Formation in the report area thickens westward to a maximum of 7,000 feet, which is nearly twice that of the type area in the Richardson Cove and Jones Cove quadrangles (Hamilton, 1961). The stratigraphic succession in the two areas is notably different. In the type area, the lower part of the formation, the Dixon Mountain Member, consists of siltstones like those of the main body of the formation in the present area, and siltstones of this kind are nearly continuous between the two areas (King, 1964). Conglomerate in the lower part of the Wilhite of the report area resembles that of the Shields Formation of the Richardson Cove quadrangle (Hamilton, 1961, p. 19), but it is not sufficiently abundant here to be identified as Shields; the base of the Wilhite is thus not known.

An abundance of limestone in the Yellow Breeches Member distinguished it from the Dixon Mountain Member in the Jones Cove quadrangle (Hamilton, 1961, p. 23). This distinction cannot be made in the report area where limestone is more uniformly distributed through the Wilhite, and conglomerate is more abundant than limestone in the higher parts of the formation. Possibly the beds here identified as the upper conglomerate part of the Wilhite Formation actually belong to the basal part of the Sandsuck Formation, as the rocks of the two formations are very similar. However, westward gradation from sandstone to conglomerate in the upper part of the Wilhite Formation in the Bates Mountain synclinorium suggests that the assignment of such beds in other places to the Wilhite is equally reasonable.

The boundary of the Wilhite with the overlying Sandsuck Formation is not exposed in the report area where both the top of the Wilhite and the base of the Sandsuck are cut off by faults. Farther east in the Jones Cove quadrangle the boundary is poorly exposed in a small area where it appears to be conformable (Hamilton, 1961, p. 26).

\section{SANDSUCK FORMATION}

Gray thin-bedded to fissile siltstone interbedded with feldspathic sandstone and conglomerate of the Sandsuck Formation crops out in two areas at the foot of Chilhowee Mountain, where it underlies the Cochran Formation of the Chilhowee Group. The similarity of its rocks to other formations of the Walden Creek Group, together with its known stratigraphic position beneath fossiliferous Lower Cambrian rocks, gives it special importance for deducing the relations of the Ocoee Series to the Paleozoic sequence in the Appalachian Valley.

The Sandsuck Formation was adapted (King and others, 1958, p. 962) from the Sandsuck Shale of Keith 
(1895, p. 3). Keith mapped as Sandsuck only finegrained rocks, but the writers found that the formation contains thick units of sandstone and conglomerate which Keith had mapped as Cochran Conglomerate.

\section{DESCRIPTION}

The Sandsuck Formation in the present report area is preserved mainly on the lower northwest slopes of Chilhowee Mountain where it is extensively mantled by debris from younger rocks. Most outcrops are in deep ravines, except for a few of the thicker coarsegrained units that form ledges on the spurs. At the southwest end of the mountain these coarse-grained rocks form the crest for a short distance.

More than half the exposed thickness of the Sandsuck consists of light-gray coarse-grained feldspathic sandstone and conglomerate, similar to conglomerate of the Wilhite Formation. These rocks are interbedded with fine-grained shaly rocks that range in thickness from thin partings between sandstone beds to units as much as 400 feet thick. Detrital particles in the sandstone and conglomerate are mostly milky and bluishgray quartz, but they include lesser amounts of feldspar, mostly albite, and minor vitreous quartzite. The cement is an iron-bearing carbonate that effervesces weakly in hydrochloric acid and on weathering leaves rusty molds; it also includes minor amounts of chlorite and sericite. The fine-grained rocks are light- to medium-gray where fresh, but most commonly are weathered to drab brown. They are largely well-laminated fissile siltstones and fine sandstones, with conspicuous bedding surfaces at $3-10 \mathrm{~mm}$ intervals that are coated with large detrital mica flakes.

In contrast to the Wilhite, the sandstone and conglomerate of the Sandsuck has fewer shale fragments and is generally thinner bedded; its siltstones lack the iron-banded layers and the green color that is common in the Wilhite. Individual coarse-grained beds of the Sandsuck, generally less than 4 feet thick, show wellmarked layering and crossbedding is common.

\section{DISTRIBUTION AND STRATIGRAPHY}

Proportions and distribution of coarse- and finegrained rocks in the Sandsuck are notably different in the two outcrop areas of the present report. At the southwestern end of Chilhowee Mountain as much as a thousand feet of it is exposed in an outcrop belt about 7 miles long. Here (inset map, pl. 2), above fault slices of younger rocks brought up along the Great Smoky fault, the lowest beds of the Sandsuck are fissile siltstone about 300 feet thick; these are overlain by a sandstone unit 50 feet thick that is characterized by sandstone beds 1-11/2 feet thick separated by shaly interbeds 1-6 inches thick. Next is about 200 feet of fissile siltstone with small lenses of sandstone, overlain at a sharp contact by about 400 feet of conglomeratic sandstone, which, in turn, is overlain by about 100 feet of fissile siltstone. This thin siltstone unit persists for 6 miles along the outcrop and is overlain throughout by the coarse basal beds of the Cochran Formation. The contact between the Sandsuck and the Cochran thus delineated is well exposed for several hundred feet on the steep slopes just north of U.S. Highway 129, where the conglomerate of the basal Cochran lies in shallow channels scoured into the siltstone, like other boundaries where conglomerate overlies siltstone in the Sandsuck Formation.

At the eastern edge of the report area (pl. 2; see also Wildwood quadrangle, Neuman, 1960) as much as 1,500 feet of the Sandsuck is preserved. More than half the exposed section in this area is siltstone, and the thin lenticular coarse-grained units are concentrated in the lower half of the exposed section. Farther east, in the Walden Creek quadrangle, there are some much thicker coarse-grained units, but these wedge out entirely in siltstone near the northeast end of the mountain (King, 1964 , p. 57-59).

Near the Little Tennessee River the Cochran seems to overlie the Sandsuck conformably, but at the northeast end of Chilhowee Mountain where rocks above and below the contact differ, and the upper sandstone and conglomerate beds of the Sandsuck are seemingly eroded and truncated by the basal beds of the Cochran, they appear to be unconformable (King, 1964, p. 59).

\section{CAMBRIAN AND CAMBRIAN(?) ROCKS CHILHOWEE GROUP}

The Chilhowee Group is a sequence of quartzites and interbedded siltstone and shale, typically exposed on Chilhowee Mountain. The name was derived from Chilhowee Sandstone of Safford (1856, p. 152-153). Formations within the group on Chilhowee Mountain

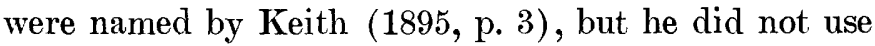
the name Chilhowee itself. Keith's formations are used in this report with only minor modifications.

Unlike the Ocoee Series, the Chilhowee Group crops out through the entire length of the central and southern Appalachians, and it has been studied in detail in several places. Correlation of the formations of Chilhowee Mountain with those farther northeast are well established (table 2).

\section{COCHRAN FORMATION}

Coarse-grained feldspathic sandstone, largely conglomeratic, forms most of the Cochran Formation. No type locality was designated by Keith; although the name presumably was taken from Cochran Creek in 
the Tallassee quadrangle (Rodgers, 1953, p. 36), no outcrops of the Cochran were found along its main course. The incomplete section along Fortner Branch of Cochran Creek (Tallassee quadrangle) between the 1000- and 1200-foot contours may have been the basis of the name. A full section that is here considered typical is on the northwest slope of Chilhowee Mountain in the Tallassee quadrangle, along the truck trail that passes through Chilogatee Gap, paralleling several power transmission lines.

TABLE 2.-Correlation of formations of the Chilhowee Group in
Tennessee and Virginia

[Adapted from King and Ferguson (1960, p. 32)]

\begin{tabular}{|c|c|c|c|c|c|}
\hline \multicolumn{3}{|c|}{$\begin{array}{l}\text { East-central Tennessee, } \\
\text { Chilhowee Mountain } \\
\text { (This report) }\end{array}$} & \multicolumn{2}{|c|}{$\begin{array}{l}\text { Northeastern Tennessee, } \\
\text { Johnson and Carter } \\
\text { Counties (King and } \\
\text { Ferguson, 1960) }\end{array}$} & $\begin{array}{l}\text { Northern Virginia, } \\
\text { Elkton and Harpers } \\
\text { Ferry areas } \\
\text { (King, 1950a) }\end{array}$ \\
\hline \multirow{4}{*}{ 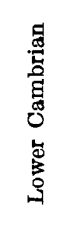 } & \multicolumn{2}{|c|}{ Shady Dolomite } & \multicolumn{2}{|c|}{ Shady Dolomite } & Tomstown Dolomite \\
\hline & \multirow{6}{*}{ 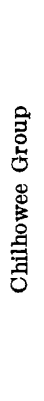 } & $\begin{array}{l}\text { Helenmode } \\
\text { Formation }\end{array}$ & క & $\begin{array}{l}\text { Helenmode } \\
\text { Member }\end{array}$ & \\
\hline & & Hesse Quartzite & 恶 & $\begin{array}{l}\text { Hesse Quartzite } \\
\text { Member }\end{array}$ & Antiatorn Ourtrito \\
\hline & & Murray Shale & 业 & $\begin{array}{l}\text { Murray Shale } \\
\text { Member }\end{array}$ & \\
\hline \multirow{3}{*}{ 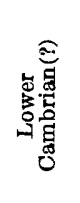 } & & Nebo Quartzite & 氛 & $\begin{array}{l}\text { Nebo Quartzite } \\
\text { Member }\end{array}$ & \\
\hline & & Nichols Shale & & Iampton Shale & Harpers Shale \\
\hline & & $\begin{array}{l}\text { Cochran } \\
\text { Formation }\end{array}$ & & aicoi Formation & $\begin{array}{l}\text { Weverton Quartzite } \\
\text { Loudoun Formation }\end{array}$ \\
\hline 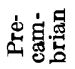 & \multicolumn{2}{|c|}{ Sandsuck Formation } & & $\begin{array}{l}\text { nic rocks of Mount } \\
\text { Rogers area }\end{array}$ & $\begin{array}{l}\text { Catoctin } \\
\text { Greenstone }\end{array}$ \\
\hline
\end{tabular}

DESCRIPTION

The Cochran Formation forms high rocky cliffs and formidable walls along some parts of the northwest face of Chilhowee Mountain. Exposures in creeks and on slopes are abundant, and have little soil or colluvial cover. Most of the formation is gray conglomeratic feldspathic sandstone, but there are subordinate thicknesses that are maroon.

The sandstone of the uppermost part of the Cochran is mostly crossbedded, medium to coarse grained, light gray, and feldspathic. Interbedded with the sandstone are discrete beds of nearly white quartzite and little or no feldspar. Concretions of gray hematite 1-4 inches in diameter dot the quartzite beds and distinguish them from those of the Nebo or Hesse higher in the Chilhowee Group. The cores of these concretions contain steel-gray slightly magnetic hematite, surrounded by nonmagnetic weathered shells.

Below the upper sandstone are distinctive beds of maroon conglomeratic sandstone and siltstone. Color differences between gray and maroon rocks appear to be caused by the composition of the interstitial matrix; there are no differences in particle composition. The maroon siltstone resembles that of the Rome and Wilhite Formations elsewhere in the sequence, but the associated green siltstone of those formations is lacking in the Cochran.

The conglomeratic sandstone of the lower part of the Cochran resembles the coarse-grained layers of the Sandsuck Formation, although that of the Cochran has a somewhat finer average grain size, with many layers in which grains are no larger than $10 \mathrm{~mm}$. Beds are 1-3 feet thick. Many are separated by thin layers of fine-grained sandstone and micaceous siltstone, but others are separated only by partings that follow scoured surfaces and by contrasts of grain size. Crossbedding is common.

Particles in the conglomeratic sandstone are $2-10$ $\mathrm{mm}$ in diameter, with variable amounts of large pebbles as much as 1 inch in diameter. Quartz is the dominant constituent, and grains larger than $1 \mathrm{~mm}$ are well rounded. Feldspar grains are also well rounded and form about 10 percent of the rock. Other fragments are vitreous quartzite and dark chlorite-rich siliceous siltstone in rounded granules and pebbles, and slate in a few angular fragments. Some other rock fragments that were studied in thin section include a tuffaceous rock composed of flat shards, now devitrified, that has the texture of a welded tuff; another rock contains spherulites of quartz in a matrix of very fine grained colorless chlorite. An iron-bearing form of calcite is present in small quantities as interstitial cement.

G. A. Swingle ${ }^{1}$ found that the heavy minerals of the Cochran were more angular and more abundant than in the higher formations of the Chilhowee Group. He found zircon, ilmenite, leucoxene, tourmaline, and hematite in four samples.

\section{DISTRIBUTION AND STRATIGRAPHY}

The Cochran Formation is mainly exposed along the northwest face of Chilhowee Mountain; it also emerges in three small fault blocks farther southeast. Complete sections of the formation are preserved only in the southwestern and northeastern parts of the mountains; in the central segment the Great Smoky fault rises into the Cochran and cuts it out entirely for a distance of 5 miles.

In the southwestern segment, geologic section 2 near Allegheny Springs and Chilogatee Gap is typical.

${ }^{1}$ Swingle, G. A., 1949, Petrography of the Chilhowee Group near Walland, Tennessee: Master of science thesis, Tennessee Univ., Knoxville, $34 \mathrm{p}$. 
Geologic Section 2.-Cochran Formation on the northwest slope of Chilhowee Mountain along the truck trail that passes through Chilogatee Gap, Tallassee quadrangle, Blount County, Tenn.

[Bedding strikes $\mathrm{N} .50^{\circ}-55^{\circ} \mathrm{E}$., and dips $40^{\circ}-50^{\circ} \mathrm{SE}$.]

Unit

Description

Thickness (

Murray Shale:

Siltstone, fissile, weathered brown and yellow-brown; exposed in drainage ditches along road. Contact with Cochran Formation is sharp and conformable.

Cochran Formation (about 1,150 ft thick):

4. Quartzite, nearly white, vitreous, medium- to coarse-grained; contains scattered grains of feldspar spotted with dark-gray and red iron concretions at top; interbedded in lower half with somewhat darker crossbedded feldspathic sandstone . . . . . . . . . . . . . . . . . . . 100

3. Sandstone, coarse-grained to gritty, feldspathic; contains scattered well-rounded pebbles as much as 1 in. in diameter, mostly of milky quartz, with others of quartzite and feldspar....... 700

2. Siltstone, maroon, thin-bedded, fissile; contains abundant large mica flakes parallel to bedding.-

1. Sandstone, coarser than unit 3, with grains larger than $5 \mathrm{~mm}$ common, and rounded pebbles as much as $11 / 2$ in. in diameter abundant. Pebbles consist of quartz, vitreous quartzite, and feldspar, with rare fine-grained siliceous rocks and other types. Beds 2-4 ft thick, commonly set apart by thin beds of fine-grained sandstone and siltstone

Sandsuck Formation:

Siltstone, fissile, micaceous; about $50 \mathrm{ft}$ thick; underlain by several hundred feet of conglomeratic, feldspathic sandstone identical to that of unit 1 of the Cochran Formation.

Keith (1895, p. 3), recognized similar subdivisions of the Cochran.

The base of the formation is at the base of the thick conglomeratic feldspathic sandstone (unit 1 of geologic section 2), overlying a thin unit of fissile siltstone of the Sandsuck Formation. This contact is best exposed 4.5 miles southwest of this section, in bluffs that overlook the Little Tennessee River (insert map, pl. 2) where its apparent conformable relations have already been described (p. D23). The lower 300 feet or more of the Cochran is nearly homogeneous thick-bedded conglomeratic sandstone thoughout the southwestern segment of exposure. The overlying maroon siltstone and sandstone are not exposed in all sections, but in many places they are indicated by red chips in the soil and loose blocks of red sandstone. Above the maroon beds the number of large rounded pebbles and the average grain size decrease very gradually, so that the uppermost third of the formation is a coarse-grained feldspathic sandstone or arkose. Feldspar decreases in abundance near the top, and vitreous nonfeldspathic quartzite forms the uppermost beds of the formation. The best exposure of the contact with the overlying
Nichols Shale is at the top of the Chilagatee Gap section where quartzite is sharply overlain by fissile siltstone without transition or interbedding.

Northeast of the Little River the Cochran Formation is as thin as 600 feet. Maroon siltstone and sandstone are more abundant here than in the southwestern exposures, and several such beds are intercalated with gray pebbly feldspathic sandstone for about the first 200 feet. Upward for about the next 400 feet red beds are lacking, but the pebbly beds are much the same in kind and abundance as those below to within about 200 feet of the top of the formation. At this level the rocks become less pebbly, finer grained, and pass into the vitreous quartzite beds of the top.

In both areas, therefore, red beds occur 600-700 feet beneath the top of the formation. The principal difference in the Cochran in these areas is the presence of the conglomerate unit beneath the red beds in the southwestern exposures and its absence in the northeast. Possibly this conglomerate unit should be assigned to the Sandsuck Formation which it resembles closely, drawing the base of the Cochran at the base of red beds. Keiths (1895 p. 3 and columnar section) definition of the Cochran however, plainly includes a lower conglomerate 500-700 feet thick beneath red beds; this unit is therefore retained in the formation in the type area.

\section{NICHOLS SHALE}

Gray fissile siltstone and platy shale that overlies the Cochran Formation was named Nichols Shale by Keith $(1895$, p. 3) from Nichols Branch of Walden Creek at the east end of Chilhowee Mountain (King, 1964, Walden Creek quadrangle). Present mapping of this formation corresponds closely with that of Keith.

DESCRIPTION
Most of the Nichols is argillaceous siltstone with some interbedded shale and fine-grained sandstone. Where fresh, these rocks are gray, but in most places they are weathered brown and yellow brown with purplish stains. The siltstone, shale, and some sandstone are well laminated and fissile, and large detrital mica flakes coat the more conspicuous bedding surfaces; however, a few sandstone beds several inches think are not laminated. The sandstone beds are feldspathic, and their heavy minerals are ilmenite, tourmaline, and zircon (Swingle ${ }^{2}$ ).

The formation is well exposed in a quarry on the east side of the Little River where its beds are somewhat crumpled tectonically; a full section that is less disturbed can be seen above the Cochran at Chilogatee Gap.

\footnotetext{
${ }^{2}$ See footnote on p. D24.
} 
The main outcrop belt of the Nichols Shale along the northwest face of Chilhowee Mountain is followed closely by the Great Smoky fault which cuts it out entirely for several miles, and elsewhere more or less affects it. Thus, where the fault is a short distance beneath it, the Nichols is only 400 feet thick in the Blockhouse quadrangle (Neuman and Wilson, 1960). It reaches its maximum thickness of about 1,000 feet near Allegheny Springs where the fault is at lower levels; in most places it is about 900 feet thick.

The Nichols is conformably overlain by the Nebo Quartzite. The argillaceous sandstone at the base of the Nebo marks a transition zone between the shaly rocks and the clean quartzites above.

\section{FOSSILS}

The only suggestions of fossils in the Nichols Shale were found about 100 feet above the base of the formation near Chilogatee Gap. Weathered fissile shale here is marked by ribbonlike impressions $1.5-2.5 \mathrm{~mm}$ wide, and as long as $8 \mathrm{~cm}$, with straight, curved, and branching forms. P. E. Cloud, Jr. (written commun., 1959, 1962), considers that the branching form especially resembles feeding burrows, which he identified as Phycosiphon, and that the straight and curved forms are probably of related origin.

\section{NEBO QUARTZTTE}

The Nebo Quartzite was named by Keith $(1895$, p. 3) for Mount Nebo Springs on the slope of Chilhowee Mountain northwest of Mount Nebo (fig. 9). Of the prominent features in this area, only the northernmost of the three peaks of Mount Nebo is formed of Nebo Quartzite and may more properly be considered the type locality of the formation. The Nebo Quartzite is prominently exposed through much of the length of Chilhowee Mountain, standing in jagged precipitous cliffs and commonly forming a well-defined ridge between the ridges of Cochran and Hesse.

\section{DESCRIPTION}

The basal 35 feet of the Nebo is a persistent unit of light-olive-green fine-grained sandstone, which contains as much as 10 percent feldspar, as well as a chloritic matrix which imparts the green color to the rock. Most of the beds in the unit are less than a foot thick, or thinner than those that overlie it, and are faintly laminated but not crossbedded.

The remainder of the formation, lying with sharp contact on the basal unit, is vitreous quartzite, light gray where fresh, but weathering darker gray or rusty brown. The quartzite forms beds 10 inches to 3 feet thick, averaging $11 / 2$ feet, which are separated by simple cracks or partings. Composition and texture vary little from one bed to the next, but many cross- bedded layers are interbedded with even-bedded layers, or with layers containing a different pattern of crossbedding. Within the beds are small textural variations or slight concentrations of dark grains.

The quartzite is medium- to coarse-grained, the grains being well rounded and moderately well sorted and between 0.5 and $2.0 \mathrm{~mm}$ i diameter. Most of them are quartz, especially in the upper part, but the lower beds contain as much as 3-5 percent feldspar grains. Nearly all the quartzite also contains widely dispersed small black grains. Heavy-mineral concentrates from 5 specimens contain detrital zircon, tourmaline, and ilmenite in varying abundance, as well as authigenic barite and hematite (Swingle ${ }^{3}$ ).

On Mount Nebo the Nebo Quartzite is 290 feet thick, but it thickens southwestward to 400 feet near Chilogatee Gap and thins northeastward to somewhat less than 200 feet near the edge of the report area (pl. 2; Wildwood quadrangle, Neuman, 1960). The contact between the Nebo Quartzite and the overlying Murray Shale is for the most part not well exposed. It is probably conformable, but is seemingly abrupt and without transition beds like those between the Nebo and the underlying Nichols.

\section{Fossus}

Most of the even-bedded layers of the Nebo Quartzite contain closely spaced narrow cylindrical tubes termed "Scolithus," standing perpendicular to the stratification and terminating at the bedding planes above and below. Besides the perpendicular tubes, the sandstone in a roadcut 0.4 mile southwest of Wolfpen Gap northeast of Montvale Springs (pl. 2; Blockhouse quadrangle, Neuman and Wilson, 1960) contains tubes about 2 inches long which are parallel to the bedding, and which may be another form of Scolithus.

Scolithus has been reported from quartzite of Early Cambrian or probable Early Cambrian age in other formations throughout the Appalachians, as well as in Scotland and Scandinavia; but it ranges into formations above the Cambrian, occurring, for example, in the Bliss Sandstone of Early Ordovician age in west Texas (Cloud and Barnes, 1948, p. 68) and in the Clinch and Clinton Formations of Silurian age in Virginia (Butts, 1940, p. 235, 246). Because of its wide range, Scolithus has little value for correlation, although it is generally believed not to occur in rocks older than Paleozoic. However, the Scolithus in the Nebo and Hesse Quartzites of Chilhowee Mountain, as well as in many other parts of the Appalachian area, occurs at levels below those of any other fossil remains, so that the organisms which formed the tubes may have been among the oldest multicellular animals.

\footnotetext{
See footnote on p. D24.
} 
Scolithus has been interpreted by many geologists as formed by the filling of holes bored downward by some form of worm. Richter (1927) compared them with tubes of sand built by the annelid worm Sabellaria alveolata Linneaus. These form "'sand reefs' of considerable stability, several meters in thickness and of wide extent at places in the North Sea off the coast of Schleswig-Holstein" (Westergård, 1931, p. 14). Similar tubes are constructed by other organisms, such as phoronids (Fenton and Fenton, 1934, p. 345-348).

The restriction of Scolithus to quartzite and sandstone suggests that the organisms that built them lived in a specialized environment. The tubes have been observed most commonly in the even-bedded sandy layers and more rarely in crossbedded layers, implying that they formed a framework which inhibited the shifting of the sand, and that the tubes were built upward rather than lining holes bored downward. The tubes parallel to bedding observed at the one locality in the Nebo might originally have projected above the enclosing sediment and later have been broken off, a few being preserved, despite their weak cementation, before they had completely disintegrated.

\section{MURRAY SHALE}

The Murray Shale, like the Nichols Shale, is mainly fissile argillaceous siltstone and fine-grained sandstone. Keith $(1895$, p. 3) stated that it was named for Murray Branch of Walden Creek; this name does not appear on available maps, but King $(1964$, p. 73$)$ has indicated Compton Branch of Walden Creek as the probable type locality.

\section{DESCRIPTION}

Most of the Murray is micaceous, fissile, silty shale and argillaceous siltstone, gray in the rare fresh exposures, but commonly weathered brown. The upper half of the formation contains platy to thin-bedded glauconitic feldspathic fine-grained sandstone, which is greenish-gray where fresh and greenish- or olivebrown where weathered. The glauconite is in green grains smaller than $0.5 \mathrm{~mm}$. Hurley and others (1960, p. 1802, 1806) analyzed this glauconite, and computed its age of formation as $550 \pm 30$ million years. Swingle ${ }^{4}$ found detrital zircon, tourmaline, and ilmenite in heavy residues of three samples of the Murray.

Like the Nichols, the Murray Shale is poorly exposed and generally masked by debris from overlying quartzite. In most places, however, it can be detected by the presence of weathered shale chips in the soil.

The fine-grained glauconitic sandstone distinguishes the upper half of the Murray from the lower half, but other details of the sequence are unknown because of

\footnotetext{
${ }^{4}$ See footnote on p. D24.
}

poor exposures. The thickness of the formation ranges from 350 feet at Murray Gap to 550 feet at Chilogatee Gap; east of the Little River it is about 450 feet thick.

The contact of the Murray with the overlying Hesse Quartizite is covered in most places. At one place in the Blockhouse quadrangle (Neuman and Wilson, 1960) interbedding between the argillaceous rocks of the Murray and the overlying quartzite was seen, but elsewhere the boundary is abrupt though conformable.

\section{Fossrus}

Fossils are known from the Murray only at Murray Gap above Montvale Springs, where Keith (1895, p. 3) reported collecting lingulellid brachiopods and trilobites. The writers searched unsuccessfully for these collections and for additional specimens of these fossils at Murray Gap. R. A. Laurence (Laurence and Palmer, 1963), however, found fossils between 20 and 60 feet above the base of the formation in new roadcuts near Murray Gap; these have been identified as the archaeocopid ostracode Indiana tennesseenis (Resser).

\section{HESSE QUARTZITE}

The Hesse Quartzite was named by Keith as Hesse Sandstone $(1895$, p. 3), probably for Hesse Creek, a southern tributary of the Little River, although this was not specifically stated. He mentions the occurrence of Hesse in "the high table-land known as the "Flats" which is drained by Flat Creek, a tributary to Hesse Creek, and this can appropriately be designated as the type locality. The top part of the formation as it was defined by Keith is now assigned to the Helenmode Formation, but otherwise the Hesse is here mapped much as it was in the Knoxville and Loudon folios (Keith, 1895, 1896a).

The Hesse Quartzite, like the Nebo, forms jagged cliffs along many miles of the crest of Chilhowee Mountain; elsewhere it forms abundant outcrops with little cover. Most of the formation is light-gray medium- to coarse-grained quartzite with well-sorted and well-rounded grains set in siliceous cement. Most beds are 2-4 feet thick, set apart by conspicuous bedding surfaces accompanied by minor contrast of texture and structure; stylolites parallel some bedding planes in exposures along the Little River. Many layers are prominently crossbedded, but others are evenly bedded with contrasting texture and thin seams of dark minerals at $1 / 4^{-}$to 1 -inch intervals. In the upper part of the formation a few beds are less well sorted and contain scattered rounded quartz grains as much as $10 \mathrm{~mm}$ in diameter. Some of these beds weather to an iron-stained friable sandstone, suggesting that they originally had a carbonate cement. A few beds near the top also contain glauconite scattered 
through the quartzite or concentrated along a few bedding planes.

Detrital zircon and ilmenite were identified in heavy mineral concentrates from 12 samples collected through the Hesse by Swingle, ${ }^{5}$ tourmaline was found in all but the highest sample. He observed that detrital grains in the Hesse are much better rounded than those of the Nebo, but that the Hesse lacks the authigenic barite and hematite observed in the Nebo.

The full thickness of the Hesse Quartzite is not preserved southwest of Look Rock. The formation is about 500 feet thick in the section that included The Flats and the adjacent crest of Chilhowee Mountain; northeast from Mount Nebo it is 540-600 feet thick. The top of the Hesse is nowhere well exposed, but in a few places interbedded quartzite, glauconitic sandstone, calcareous sandstone, and shale shows that the Hesse grades upward into the Helenmode.

Scolithus tubes are abundant in many even-bedded layers of the Hesse; but beds with Scolithus are fewer, and the tubes are generally shorter than in the Nebo. No other fossils were observed.

\section{HELENMODE FORMATION}

The Helenmode Formation, or top unit of the Chilhowee Group on Chilhowee Mountain, is derived from the Helenmode Member of the Erwin Formation of northeasternmost Tennessee (King and others, 1944, p. 31-32; King and Ferguson, 1960, p. 43-44), where it was applied to the "transition beds" between the Erwin and Shady Formations of previous reports (Stose and Schrader, 1923, p. 68). The upper beds on Chilhowee Mountain so resemble those of northeasternmost Tennessee in position and character that they can appropriately be given the same name, although on Chilhowee Mountain, where the inclusive term Erwin Formation is not used, the Helenmode is classed as a formation.

No unit like the Helenmode was recognized in this position by Keith (1895), and in many places he probably mapped it with his Hesse Sandstone. In other places, however, as at Little River gap, where its shaly beds are well exposed, he mistakenly identified these as Murray Shale.

\section{DESCRIPTION}

The Helenmode Formation forms a nearly continuous band of outcrop northwest of Miller Cove at the foot of the dip slopes of Hesse; it is also preserved in a few outliers in The Flats farther southwest. The formation is generally much weathered and concealed by quartzite wash from formations higher on Chilhowee Mountain, but sequences of the unit are exposed in some of the ravines which cross its outcrop, especially

${ }^{5}$ See footnote on p. D24. northeast of the Little River. A partial section of the beds just overlying the Hesse Quartzite is exposed on the northeast side of the Little River at the southeastern end of its gap through Chilhowee Mountain.

The Helenmode Formation consists of argillaceous rocks and interbedded sandstone. The argillaceous rocks are silty shale and siltstone containing abundant large detrital mica flakes and scattered to abundant very well-rounded glauconite grains $0.2-0.5 \mathrm{~mm}$ in diameter. All the argillaceous rocks observed have been weathered, but the fresh rocks from which they were derived may have resembled those of the Murray Shale. In the lower part of the formation the argillaceous rocks are interbedded with thin quartzite layers like those of the Hesse. Higher up are several sandstone beds which contain rounded quartz grains $1 \mathrm{~mm}$ in diameter; these beds weather friable and with voids between the grains, probably because of removal of an original carbonate cement. The top of the formation is nowhere visible, although dolomite close to the base of the overlying Shady is exposed in some places. The upper contact is mapped principally from the residuum of the two formations. Because of the poor exposures of the Helenmode, especially at the top, its thickness is uncertain, but it is probably between 50 and 175 feet.

Heavy-mineral concentrates of four samples from the Helenmode Formation contain detrital zircon and tourmaline, and three of the samples contain ilmenite (Swingle ${ }^{6}$ ).

The Helenmode Formation is seemingly gradational and conformable with the underlying Hesse Quartzite, and the apparent carbonate content of its upper sandstone beds suggests that it has the same relation with the overlying Shady Dolomite. Conformable relations between the Helenmode and the beds below and above have also been observed in the better exposed sections in northeasternmost Tennessee (King and Ferguson, 1960 , p. 43-44).

Nevertheless, regional relations between the Helenmode and adjoining units are poorly understood because of discontinuities between outcrop areas, the lack of paleontologic control, and the poor exposures of the contacts. The change from deposition of clastic sediments during Chilhowee time to deposition of" carbonate sediments during Shady time is striking and abrupt at all places in the Appalachians. Intervening transitional beds, such as the Helenmode as classified, would seem to be a time-stratigraphic unit of wide extent, but the possibility of intergrading along the strike has been suggested (King and Ferguson, 1960, p. 36).

See footnote on p. D24. 
FOSSILS

Fossils were collected from the upper part of the Chilhowee Group on Chilhowee Mountain by C. D. Walcott and his assistants in 1890, they have been mentioned in several reports, although the record is conflicting. Keith $(1895$, p. 3$)$ mentioned the occurrence of lingulellid brachiopods and trilobites at two localities, the crest of the mountain above Montvale Springs and the east side of the Little River gap, both of which he assigned to the Murray Shale. As indicated above, the first locality is clearly in the Murray. The second locality is now known to be in the Helenmode Formation.

According to Walcott (1891, p. 302), the locality is "in the shale about 20 feet above the quartzite in the upper shale bed"; labels on the specimens in the U.S. National Museum state that this is at "the east end of the Little River gap, Chilhowee Mountain, Tennessee." Shale of the Helenmode, corresponding to these descriptions, is still exposed on the northeast side of the river. From the collections made here, a fragment of an Olenellus (Walcott, 1891), Isoxys chilhoweana Walcott, Indiana tennesseensis Resser, and Hyolithes have been identified (Resser, 1938, p. 25).

Reexamination of the locality during the present investigation suggests that these fossils must be extremely rare. Intensive search by the present authors has yielded only fragments of an inarticulate brachiopod, probably of the genus Paterina (A. R. Palmer, written commun., 1956).

\section{AGE OF THE CHILHOWEE GROUP}

The Chilhowee Group has long been classed as Early Cambrian in age (Walcott, 1891, p. 299-300), on the basis of fossils reported from the Murray Shale. With the observation that some of these fossils were actually from the Helenmode Formation, and that no older fossils could be found, the writers and their associates were uncertain of the age of all the older formations of the group (King and others, 1958, p. 964; Neuman and Wilson, 1960).

Laurence's discovery of Lower Cambrian fossils in the Murray establishes the age of this and the overlying formations, but the underlying formations-the Nebo, Nichols, and Cochran-are still classed as Cambrian (?). Thus, the boundary between Cambrian rocks and those of Cambrian(?) age in the Chilhowee Group has been moved downward from the base of the Helenmode Formation to the base of the Murray Shale. The Sandsuck Formation beneath the Chilhowee Group is assigned to the Precambrian.

\section{SHADY DOLOMITE}

The Shady Dolomite, which overlies the Chilhowee Group in the Chilhowee Mountain area and elsewhere in eastern Tennessee, was not recognized during the early surveys. Safford (1869, p. 203-226) divided the strata which succeed the Chilhowee into a Knox Sandstone, Knox Shale, and Knox Dolomite-the Rome, Conasauga, and Knox of present usage. Although he observed in many places the dolomite now known as Shady, he did not understand its true position between the Chilhowee and Rome. Keith $(1892,1895)$, in his work for the Knoxville folio, followed Safford (1869, geologic map) in classing the dolomite which succeeds the Chilhowee Group of Chilhowee Mountain as Knox, which he interpreted as lying on the Chilhowee with a marked unconformity and as separated from it by a hiatus representing the time of formation of the Cambrian formations that he had mapped in nearby areas. The succeeding red shales of the Rome Formation were supposed to be a "shore deposit of the Knox Dolomite," related to this unconformity. It was only later, when mapping farther northeast in Tennessee, that Keith $(1903$, p. 6) recognized the Shady as a unit distinct from and much older than the Knox, but he did not indicate specifically the implications of this revision to the rocks which he had previously called Knox in the Chilhowee Mountain area.

The account of the Shady given herein is based mainly on work of C. A. Tucker, Jr., in 1950 as a unit of the Great Smoky Mountains project and as a master of science thesis at the University of Tennessee.

\section{DESCRIPTION}

The Shady Dolomite consists of dolomite of several kinds and a few interbeds of dolomitic shale. Most of the dolomite is light gray, medium to coarse grained, and crystalline, and forms massive to laminated beds 1-4 feet thick. The dolomite low in the sequence is thicker bedded, coarser grained, and lighter colored than that higher up; massive beds as much as 4 feet thick are common here. The dolomite commonly contains round to irregular masses of very fine grained chalcedonic chert as is common in the Shady in other areas (for example, the Del Rio district, Tennessee, described by Ferguson, 1951, p. 36).

Shaly dolomite is most abundant in the upper third of the formation, where two unnamed members are characterized by its abundance. Most of it is mediumgray, but one distinctive and persistent greenish-gray bed at the base of the upper shale member served as a key bed for mapping.

The different rock types of the Shady, particularly those in the upper part of the sequence, can be seen in a section along Wolf Creek in the southwestern part of Miller Cove (geologic section 3; fig. 6). Samples from this section were analyzed spectrographically, and thin sections from them were studied. 


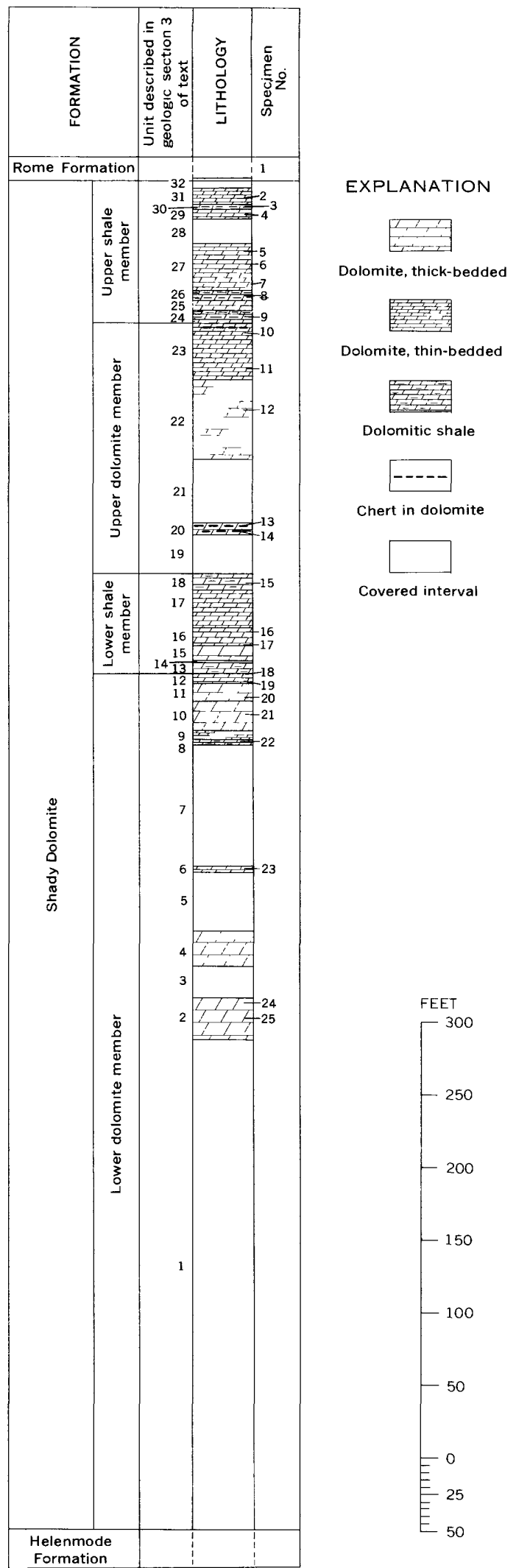

Spectrographic analyses for iron, manganese, zinc, lead, and barium [Analyst, Harry J. Rose, U.S. Geol. Survey]

\begin{tabular}{|c|c|c|c|c|c|c|}
\hline Specimen No. & $\mathrm{Fe}$ & $\mathrm{Zn}$ & Mn & $\mathrm{Pb}$ & $\mathrm{Ba}$ & $\begin{array}{l}\text { Percent } \\
\text { loss on } \\
\text { ignition }\end{array}$ \\
\hline & $\begin{array}{l}9 \\
.3 \\
.5 \\
.3 \\
.3 \\
2 \\
.3 \\
.5 \\
2 \\
.4 \\
.3 \\
.2 \\
.2 \\
.4 \\
2 \\
3 \\
2 \\
.4 \\
.2 \\
.4 \\
.3 \\
3 \\
.5 \\
.3 \\
.4\end{array}$ & $\begin{array}{l}0 \\
0 \\
0 \\
0 \\
0 \\
0 \\
0 \\
0 \\
0 \\
0 \\
0 \\
0 \\
0 \\
0 \\
0 \\
0 \\
0 \\
0 \\
0 \\
0 \\
0 \\
0 \\
0 \\
0 \\
0\end{array}$ & $\begin{array}{l}0.005 \\
.04 \\
.006 \\
.03 \\
.004 \\
.008 \\
.02 \\
.003 \\
.006 \\
.04 \\
.03 \\
.04 \\
.05 \\
.07 \\
.01 \\
.01 \\
.02 \\
.06 \\
.03 \\
.06 \\
.07 \\
.02 \\
.06 \\
.04 \\
.05\end{array}$ & $\begin{array}{l}0 \\
.0003 \\
.001 \\
.0003 \\
0 \\
0 \\
0 \\
0 \\
0 \\
.001 \\
.0003 \\
0 \\
0 \\
0 \\
0 \\
.0004 \\
.0006 \\
.0005 \\
0 \\
0 \\
0 \\
.0006 \\
0 \\
0 \\
0\end{array}$ & $\begin{array}{l}0.03 \\
.008 \\
.02 \\
.002 \\
.03 \\
.2 \\
.03 \\
.006 \\
.02 \\
.003 \\
.0007 \\
.0004 \\
.0004 \\
.001 \\
.01 \\
.02 \\
.02 \\
.001 \\
.0007 \\
.0006 \\
.001 \\
.03 \\
.002 \\
.0008 \\
.0002\end{array}$ & $\begin{array}{r}4.7 \\
44.5 \\
13.0 \\
42.0 \\
42.0 \\
35.8 \\
40.8 \\
37.2 \\
16.5 \\
45.1 \\
45.1 \\
45.0 \\
44.9 \\
43.1 \\
20.9 \\
24.6 \\
21.3 \\
44.6 \\
44.9 \\
40.3 \\
43.8 \\
25.3 \\
37.8 \\
44.2 \\
45.3\end{array}$ \\
\hline
\end{tabular}

FIgure 6.-Columnar section and results of spectrographic analyses of Shady Dolomite from measured section along Wolf Creek, Kinzel Springs quadrangle. 
Geologic section 3.-Shady Dolomite along Wolf Creek, Kinzel Springs quadrangle, Blount County, Tenn.

[Section measured by tape and compass by P. B. King, R. B. Neuman, and C. A. Tucker, Jr., in 1950 . Beds strike N. $70^{\circ}-80^{\circ} \mathrm{E}$. dip $20^{\circ}-30^{\circ} \mathrm{S}$. The section combines data from several traverses along Wolf Creek and its valley]

Unit Description

Rome Formation; siltstone, dark-reddish-gray ( $\mathrm{MC}-1$ ) Upper shale member (99 ft thick) :

32. Covered . . .

31. Dolomite, medium brownish-gray, finegrained; laminated in beds $1-3$ in. thick (MC-2)

30. Shale, dolomitic, gray, platy; closely spaced slightly darker fine laminations; 1 bed of gray dolomite 2 in. thick in middle (MC-3)

29. Dolomite, light-yellowish-gray, mediumgrained; in 1- to 4-in. beds (MC-4)

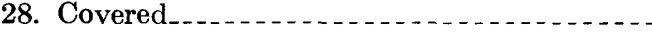

27. Dolomite, light- to dark-gray, very finegrained; in 1/4- to 3-in. beds (MC-5, MC-6, $\mathrm{MC}-7)$

26. Dolomite, medium-gray, very fine grained, faintly laminated, shaly (MC-8) . . . . .

25. Dolomite, medium- to dark-gray, finegrained; in 6- to 12-in. beds .

24. Shale, dolomitic, greenish-drab, argillaceous and silty; indistinctly laminated, but fissile (MC-9) ..............................

Upper dolomite member (192 ft thick):

23. Dolomite, medium-gray, fine-grained; in 1- to 2-in. beds; large lenses and spherical nodules of chalcedonic chert in top $2 \mathrm{ft}$ (MC-10, MC-11) ...................

22. Dolomite, light-gray, fine-grained; much covered (MC-12)

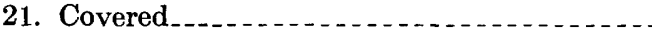

20. Dolomite, dark-gray, fine-grained, and medium-gray, medium-grained; in 1- to 2-in. beds; irregular-shaped masses of chalcedonic chert (MC-13) ..........

19. Covered

Lower shale member ( $64 \mathrm{ft}$ thick):

18. Shale, dolomitic and silty; mostly light-gray where fresh, with brownish-gray more argillaceous layers more abundant in lower part; weathered rock is brown and platy (MC-15)

17. Dolomite, very light gray; bedding laminations etched out on weathered surfaces; partly covered........................

16. Dolomite, medium-gray, fine-grained, silty, well-laminated; weathered rock is brown shale with well-marked light and dark laminations (MC-16, MC-17) . . . . . . .

15. Dolomite, very light-gray, medium-grained, sugary _...............................

14. Dolomite, dark-gray; forms a single bed

13. Shale, silty; weathered brown and silty; presumably gray where fresh. ...........

Lower dolomite member (about $600 \mathrm{ft}$ thick):

12. Dolomite, very light-gray, fine-grained; in part laminated, with laminae etched on weathered surface (MC-18, MC-19)
Rome Formation-Continued

Lower dolomite member-Continued

Unit

Description

Thickness

(feet)

11. Dolomite, very light-gray, medium-grained, sugary; in thick nonlaminated beds, partly covered (MC-20) ..............

10. Dolomite, medium-grained; fine-grained with coarse grains in small irregular areas; nonlaminated beds 2-4 ft thick (MC-21)

9. Mostly covered; a few small outcrops of gray medium-grained dolomite.............

8. Dolomite, light-gray, fine-grained, laminated and shaly, silty; weathers light brown

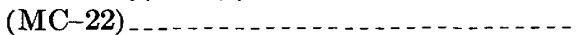

7. Covered .

6. Dolomite, medium-gray, very fine grained; forms ledge in creek (MC-23) ....... 3

5. Covered ........................... 22

4. Dolomite, very light gray, coarse-grained, sugary; crops out in roadbed ........... 24

3. Covered

2. Dolomite, very light-gray, coarse-grained, sugary; exposed in ledges in creek; bedding obscure (MC-24, MC-25) ............ 30

1. Covered; thickness calculated from distance to exposures of Helenmode Formation . _ 350

Helenmode Formation at base.

24

The spectrographic analyses (fig. 6) for iron, zinc, manganese, lead, and barium-metals obtained from ores mined in some other areas underlain by the Shady Dolomite in eastern Tennessee-show that only very small amounts of these metals are present in Miller Cove. Chemical analyses of the Shady Dolomite from the manganese mining districts in northeastern Tennessee (King and others, 1944, p. 57-58) showed from 0.13 to 1.24 percent manganese, compared to the maximum of 0.07 percent in Miller Cove. Analyses of unveined carbonate rocks from the barite mining district at Cartersville, Ga. (Kesler, 1950, p. 13, 46, 51-53), however, do not reveal the presence of barium which is found in veins in fresh rock and mined from secondary deposits.

The thin sections show mosaics of interlocking dolomite crystals, with silt and chlorite in more shaly parts. Variation in grain size of the dolomite generally follows bedding but occurs in irregular patches in some thin sections. In one sample (MC-24) from unit 2 of geologic section 3 , spheres about $1 \mathrm{~mm}$ in diameter, relics of ooids, pellets, or detrital particles, $91 / 2$ are revealed by rims of very small crystals of dolomite around coarse-grained cores. Thin sections of shaly dolomite have thin chloritic bands, commonly with quartz silt, that alternate with purer and fine-grained dolomite. Small calcite veins cut all types and are undeformed. Dolomitization of the Shady, therefore, seems to replace and largely obliterate original sedimentary texture but antedates tectonic deformation. 
As is true of other dolomites of the southern Appalachians, weathered surfaces of dolomite in the Shady have a brown yellow-gray chalky rind, and are marked by a crosshatched pattern that results from the faster solution of calcite veinlets than of dolomite.

Unconsolidated surficial materials blanket most of the area of the Shady, and its surface is littered with residual jasperoid, the "jaspery rock" noted by Safford (1869, p. 209). Jasperoid occurs in Miller Cove as loose yellow-brown to dark-red boulders a few inches to several feet in diameter or as ledges more than 100 feet long on some slopes. Areas of abundant jasperoid are indicated by the letter $J$ on plate 3 . The jasperoid is of two kinds: (1) a siliceous boxwork of intersecting straight walls formed by drusy quartz, enclosing open spaces of a wide variety of shapes and dimensions, and (2) dense apparently massive siliceous rock with a dull luster. In some specimens, gradation from boxwork to dense jasperoid takes place as the walls of the boxwork thicken and become more numerous and the openings become correspondingly smaller. Some jasperoid, however, looks like breccia, with angular blocks of the dense variety embedded in boxwork. In a few places, angular fragments of white quartzite like that of the Hesse are embedded in dense jasperoid.

Important occurrences of jasperoid in areas apparently underlain by the Shady Dolomite are at the southwestern end of Miller Cove, and it was prospected for iron ore (Keith, 1895, economic geology map and p. 6) on the adjacent lower slopes of Chilhowee Mountain in The Flats. Wider areas with abundant jasperoid are underlain by the Rome Formation in Miller Cove, on the crests and sides of low domical hills. Jasperoid was not seen in outcrops of dolomite, although it was seen enclosed in weathered shaly rocks of the Rome Formation on a farm road, 0.1 mile east of BM 1161 in the southwestern part of Miller Cove (pl. 3).

The distribution of jasperoid in Miller Cove shows that (1) it is associated with both the Rome Formation and the Shady Dolomite, (2) it occurs at altitudes from 1,000 to 1,800 feet, (3) it is not known in freshrock exposures of either the Shady or the Rome, and (4) it occurs in structurally simple areas as well as in those which appear to be considerably broken up by faulting. Accordingly, jasperoid seems more likely a part of the surficial mantle than of the Shady Dolomite, and thus post-Paleozoic in age rather than Cambrain. (See discussion of surficial geology, p. D73.)

Most of the surficial cover over the Shady is col- luvial or alluvial, but in a few places, particularly in areas underlain by the upper part of the formation, the mantle is orange-red and yellow residual clay showing remnants of bedding. Much of this clay contains fragments of dense light-colored chalcedonic chert, like that of fresh dolomite outcrops. The degree of preservation of fresh-rock structures varies with the amount of insoluble constituents in the original rock: that of the more shaly dolomite is preserved virtually intact, whereas the nearly pure dolomite is reduced to amorphous and massive clay. This residuum, lying on a pinnacled surface of the fresh rock, is exposed in cuts along Tennessee Highway 73. In parts of the cuts there, the lighter colored residual clays are mingled irregularly with deep-red weathered silt and gravel of alluvial origin.

\section{STRATIGRAPHIC RELATIONS AND AGE}

The average thickness of the Shady Dolomite in Miller Cove is 1,100 feet, of which about 700 feet belongs to the lower dolomite member, 100 feet to each of the shale members, and 300 feet to the dolomite member between them. This total thickness is about the same as the 1,000 feet measured in the Del Rio district (Ferguson, 1951, p. 37) and 950-1,150 feet in northeasternmost Tennessee (King and Ferguson, 1960 , p. 45). Although the succession of rock types in those areas was not recognized in Miller Cove, silty beds near the top of the formation in all of them suggest a transition toward the overlying Rome Formation.

No fossils or traces of fossils are known from the Shady Dolomite in Miller Cove or elsewhere in Tennessee, although they have been recorded from the Austinville district in southern Virginia (Currier, 1935, p. 35-36; Cooper, 1951) and from the Cartersville district in Georgia (Kesler, 1950, p. 11). Even in the Austinville district most of the fossiliferous beds that have been ascribed to the Shady are now correlated with the Rome Formation, although some beds with Archaeocyathis are still considered to belong to the Shady (Brown, 1953, p. 1217; oral commun., 1955). Nevertheless, fossils in formations that underlie and overlie it indicate that the Shady is of Early Cambrian age.

\section{ROME FORMATION}

The red shale, sandstone, and other rocks in Miller Cove, originally classed with the Knox as already indicated, are now known to belong to the Rome Formation. Deep-red or maroon shale, calcareous siltstone, 
and fine-grained sandstone form most of its exposed thickness. The fine-grained rocks are well laminated and fissile, but some of the siltstone and sand.stone is obscurely laminated and forms well-defined beds as much as 6 inches thick. Soft, yellow, argillaceous, and sandy beds, $1 / 2$ inch to 3 feet thick, that were probably gray where fresh, are interbedded with red beds in weathered exposures. Glauconite grains occur in both red and nonred beds, as do large mica flakes on bedding surfaces.

Most exposures in Miller Cove are deeply weathered, but the characteristic deep-red color of the formation persists in the weathered rock and in much of the soil, and in some places blocks of maroon sandstone lie loose on the surface. Much of its outcrop area is covered by surficial deposits with abundant jasperoid like that of the Shady.

The Rome is exposed in two isolated areas on opposite sides of the Little River, and in a small area along a cross fault near the high school at Walland (pl. 3). It is about 800 feet thick in the southwesternmost area and thinner in the others, because it is cut off by a fault that brings the Wilhite Formation over it. Thus, only the lower half of the formation is exposed, for in the northeasternmost Tennessee and adjacent Virginia it is 1,250-1,800 feet thick (King and Ferguson, 1960, p. 53).

No fossils were found in the Rome Formation in Miller Cove. Lower Cambrain fossils from outcrop belts to the northwest have established the Early Cambrain age of the formation (Resser, 1938, p. 25-26).

\section{MISSING INTERVAL}

The Paleozoic stratigraphic sequence in the report area is interrupted by thrust faults, although the full sequence is known elsewhere in the Valley and Ridge province. The Rome of the report area is the youngest formation in the upper plate of the Great Smoky fault; it is also the oldest formation exposed beneath and northwest of this fault in the Valley and Ridge province.

The present report is concerned primarily with the rocks of the Great Smoky Mountains, and the northwestern edge of the accompanying map (pl. 2) is the base of the Middle Ordovician Series. The rocks between the Rome and the Middle Ordovician of the Valley and Ridge province are described in other reports on bordering areas (Wildwood quadrangle, Neuman, 1960; Blockhouse quadrangle, Neuman and Wilson, 1960). They comprise the following units:

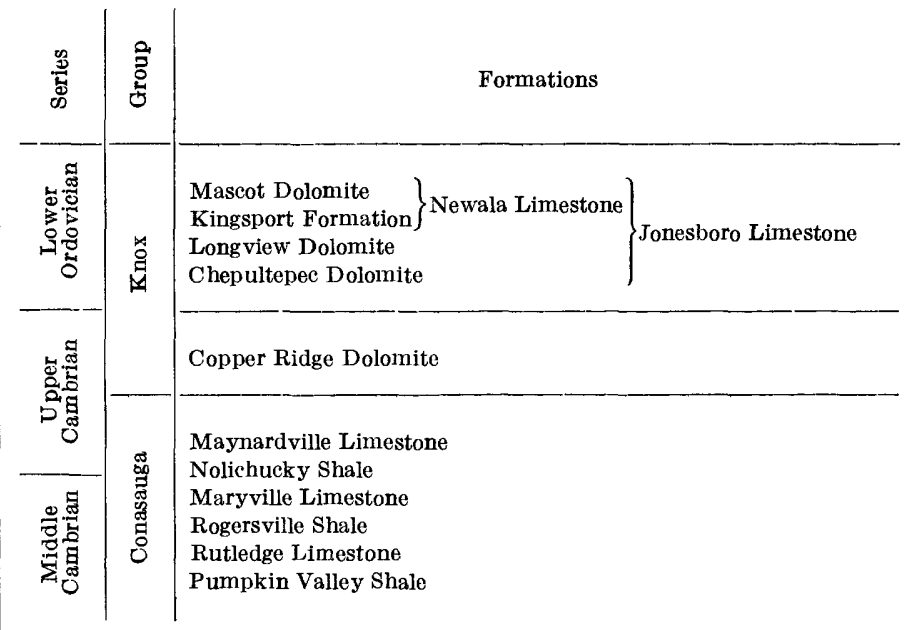

ORDOVICIAN SYSTEM

LOWER ORDOVICIAN SERIES

KNOX GROUP-JONESBORO LIMESTONE

Within the report area (pl. 2) the Knox Group is exposed in windows of the Great Smoky thrust sheet and in small tectonic slices along the Great Smoky fault. The windows form open valleys within the foothills of Tuckaleechee Cove, Cades Cove, and at Calderwood on the Little Tennessee River. The Knox of these areas is of the dominant limestone facies which is characteristic of the southeastern belts of the group in Tennessee and which is classed as Jonesboro Limestone (Rodgers, 1953 p. 62; redefined from U1rich, 1911, p. 671-672). The Jonesboro, which is not subdivisible into mappable units, is equivalent to the several formations of the Ordovician parts of the Knox Group northwest of the report area, which are listed above (Rodgers, 1953, p. 56).

\section{DESCRIPTION}

The Jonesboro Limestone is dominantly light to medium-gray fine-grained to aphanitic limestone in 6 -inch to 3-foot beds. The most common is light-gray and aphanitic, marked by thin wavy clay partings that define bedding at intervals of a few inches. Other types include: (1) nearly massive gray fine-grained limestone, which commonly contains silicified specimens of the gastropod operculum Ceratopea and nonsilicified remains of the other gastropods; (2) darker limestone, fine-grained, with silty partings; (3) calcarenite with scattered quartz sand grains; $(4)$ platy limestone, much of which contains scattered wellrounded grains of quartz sand; and (5) salmon-pink limestone breccia at threep places in Tuckaleechee Cove.

Dolomite forms less than 10 percent of the Jonesboro. It is fine grained but more granular than the limestones. Most of the dolomite beds are sandy and 
about a foot thick with nearly parallel laminae at 1 - to 5 -mm intervals. Dolomite beds stand out from the limestone beds on weathering because of their dull surfaces that are creased by a crosshatched pattern which follows small calcite-filled joints.

Nodular and disseminated chert is sparse in the fresh rock, but is concentrated in the residual mantle. The nodular chert is either black and dense or white and porcelaneous. Disseminated chert is white and porous and forms irregular masses about one-eighth inch in diameter. Silica also replaces some fossils.

The lithologic features just described are relatively constant throughout the exposures of the Jonesboro in the window areas, despite the occurrence of fossils which indicate varied ages. The beds in the southwestern part of Tuckaleechee Cove, in Cades Cove, and probably at Calderwood are equivalent to the Longview Dolomite and Kingsport Formation and are thus older than those beds in the main part of Tuckaleechee Cove whose fossils indicate them to be equivalent to the Mascot Dolomite.

The Jonesboro of the cove areas has been much repeated tectonically, so that its original thickness is difficult to determine. An apparent thickness of 2,000 feet occurs in Tuckaleechee Cove; this area contains many faults and reversals of dip, so that the actual thickness is probably considerably less. This is confirmed by known thicknesses of the Ordovician part of the Knox Group in other areas, in which equivalents of the part exposed in the report area are about 1,000 feet thick. The Jonesboro in its type section on Jockey Creek, Green County, Tenn., is about 2,000 feet thick (Oder, 1934, p. 495-497; Rodgers, 1953, p. 62), but more than half is older than beds exposed in the report area. In the northwestern belts of the Knox, the equivalent Mascot Dolomite is $400-800$ feet thick, the Kingsport Formation about 200 feet, and the Longview Dolomite about 250 feet (Rodgers, 1953, p. $57-58$ ).

The Jonesboro Limestone is overlain unconformably by the Middle Ordovician Lenoir Limestone. Limestone conglomerate at the contact in the report area is like that in other areas where relief as much as 140 feet has been recorded (Bridge, 1955, p. 727).

\section{Fossins}

Most beds of the Jonesboro Limestone show no trace of fossil organic remains, but some layers contain brachiopods, mollusks, and more rarely, trilobites. Most of these are silicified, but silicified gastropod shells other than operculae and silicified cephalopods other than siphuncles have not been found. The silicified fossils stand out in relief on weathered surfaces, and they may be freed by dissolving the rock in hydrochloric acid.

The most important fossils in the Jonesboro Limestone are listed below by the areas of their occurrence, from southwest to northeast:

Calderuood vindow: A small and unidentifiable species of Finkelnburgia was obtained from the eastern edge of the large quarry near the west end of the window, suggesting that these beds belong to the lower part of the formation.

Cades Cove: Fossils in Cades Cove are known best from two localities (Neuman, 1947, p. 171) : (a) a roadside pinnacle of weathered limestone, $1,200 \mathrm{ft}$ southwest of Gregorys Cave, which contains the brachiopods Diaphelasma pennsylvanicum Ulrich and Cooper and Finkelnburgia virginica Ulrich and Cooper, and fragments of a trilobite resembling Hystricurus, that indicate a Longview age; (b) the uppermost bed in a small quarry about $1,000 \mathrm{ft}$ east of Gregorys Cave, which contains the brachiopod Xenelasma syntrophioides Ulrich and Cooper, of probable Kingsport age (Cloud, 1948, p. 472).

Tuckaleechee Cove: Operculae of the gastropods Certatopea tennesseensis Oder and $C$. subconica Oder are known from several places in Tuckaleechee Cove in the area of plate $\mathbf{3}$ and in the Wear Cove quadrangle (King, 1964,), and beds nearby and at several other places yielded brachiopods belonging to the genera Tritoechia and Diparalasma, all indicating correlation with the Mascot Dolomite (Yochelson and Bridge, 1957 p. 293). Associated nondiagnostic fossils include siphuncles of cephalopods and small circular cystoid columnar plates.

A species of the brachiopod Diaphelasma associated with a tightly coiled gastropod resembling Lecanospira in outcrops 0.3 mile southeast of a road intersection named Red Bank at the southeastern end of Dry Valley (pl. 3) indicates a Longview age for these beds.

Tectonic slice north of Mount Nebo: Of the several tectonic slices of Jonesboro Limestone beneath the Great Smoky fault, only the one just to the west of the Little River (pls. 2 , and 3 ; fig. 9) yielded fossils, and these are silicified specimens of a species of Diparelasma of Mascot age.

\section{MIDDLE ORDOVICIAN , SERIES}

Rocks of the Middle Ordovician Series in the report area contain considerable terrigenous material and thus contrast sharply with the relatively clean carbonate rocks of the Lower Ordovician Series. More than 7,500 feet of sandy and shaly Middle Ordovician rocks contrast strongly with their cleaner and thinner correlatives to the northwest. These rocks were described in an earlier report (Neuman, 1955), which is summarized here.

Middle Ordovician rocks crop out in three belts in the report area (pl. 2) : (1) the main belt northwest of the Guess Creek fault (the Tellico-Sevier belt); (2) a narrower belt between the Guess Creek and Great Smoky faults; and (3) in Tuckaleechee Cove.

Formations recognized in the Tellico-Sevier belt are (from youngest to oldest) :

Bays Formation

Sevier Formation, with Bacon Bend Member at top 
Chota Formation

Tellico Formation

Blockhouse Shale, with Toqua Sandstone Member in lower part, and Whitesburg Limestone Member at base

Lenoir Limestone, with Mosheim and Douglas Lake Members

In Tuckaleechee Cove, the Middle Ordovician includes the Lenoir Limestone and the Blockhouse Shale. Middle Ordovician rocks between the Guess Creek and Great Smoky faults are so much deformed that they cannot be separated into formations and are described here as Tellico Formation and Blockhouse Shale, undifferentiated.

\section{LENOIR LTMESTONE}

The Lenoir Limestone (Safford and Killebrew, 1876, p. 130-131), at the base of the Middle Ordovician Series, consists of gray, cobbly, argillaceous limestone -termed the argillaceous limestone member-lightgray aphanitic limestone of the Mosheim Member (Ulrich, 1911, as Mosheim Limestone), and detrital limestone of the Douglas Lake Member (Bridge, 1955, p. 727$)$; these limestones are not separately mapped in the present report except in the small area on plate 5 .

\section{DESCRIPTION}

The argillaceous limestone member of the Lenoir is gray to dark gray, fine grained, and nodular with concentrations of argillaceous material surrounding small lenses of less argillaceous limestone. Some of the limestone contains nodules of dense black chert, and at one place in Tuckaleechee Cove it has small rounded quartz grains. The Mosheim Member is light-gray aphanitic limestone in beds 1-4 feet thick that have characteristic smooth or fluted very light colored weathered surfaces. Some beds are flecked with small calcite crystals; others are calcarenites with poorly defined rounded grains and matrix of the same material. In a few places in Tuckaleechee Cove the Mosheim contains scattered rounded quartz grains, and in the Walker Hollow map area (pl. 5) it contains blocks of dolomite which apparently were derived from the underlying Jonesboro Limestone.

The Douglas Lake Member occurs only at one locality near the western edge of the map area. There, in a quarry $0.8 \mathrm{~mm}$ northeast of Ninemile Creek, it is 55 feet thick, with limestone breccia at the base, succeeded by vermillion and yellowish-gray silty limestone containing fragments of limestone and dolomite, and light-gray calcarenite crowded with the brachiopod Rostricellula varicosta Cooper.

The Lenoir along the northwestern edge of the map area is between 75 and 150 feet thick. Although it is discontinuously exposed and much covered by surficial materials it forms a persistent subtle topographic depression. Along this belt the argillaceous limestone member and the Mosheim Member replace each other. One or the other forms the entire unit in many sections; in others the Mosheim forms the lower part and is overlain by the argillaceous limestone member. Beyond the report area, however, the two have been found to intertongue (Bridge, 1955, pl. 1).

In Tuckaleechee Cove the Lenoir is about 25 feet thick, and the Mosheim Member is far more common than the others. In many places in the cove the Blockhouse Shale rests directly on the Jonesboro; but the absence of the Lenoir is due to faulting, as seen by detailed observations in the vicinity of Walker Hollow (pl. 5; p. D48).

The Lenoir is overlain disconformably by the Whitesburg Limestone Member of the Blockhouse Shale, as indicated by the absence of an intervening faunal zone that is widespread toward the northwest and north. (Neuman, 1955, p.166). Physical evidence for this disconformity was seen only in Walker Hollow in Tuckaleechee Cove (pl. 5) where a thin film of quartz sand at the base of the Whitesburg coats the surface of the Mosheim and fills narrow cracks in its upper beds. The basal few inches of the Whitesburg here also contains angular fragments of aphanitic Mosheim limestone as much as 1 inch in diameter.

\section{FOSSILS}

Brachiopods are moderately abundant in the argillaceous limestone member and in lenses in the Douglas Lake Member. Cross sections of gastropods are common in the Mosheim Member, but identifiable specimens are rare (Neuman, 1955, p. 148, 172, pl. 25, figs. 38 , 39 ; King 1964, p. 83).

Fossils identified from the report area are-

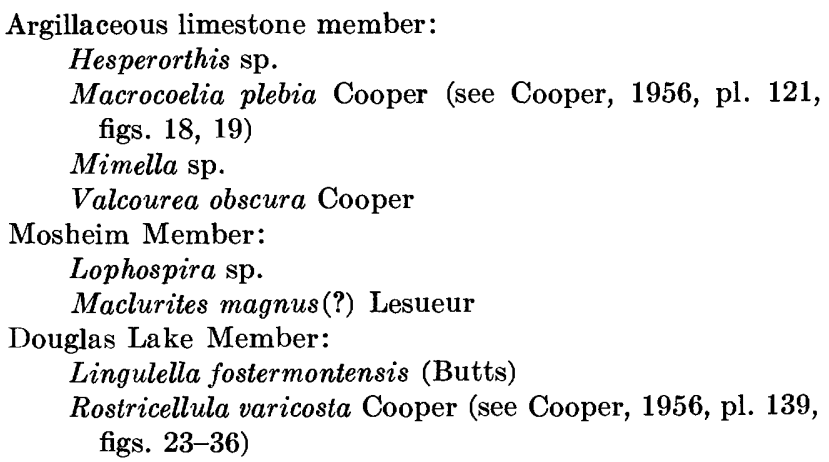
figs. 18, 19)

Mimella sp.

Valcourea obscura Cooper

Mosheim Member:

Lophospira sp.

Maclurites magnus(?) Lesueur

Douglas Lake Member:

Lingulella fostermontensis (Butts)

Rostricellula varicosta Cooper (see Cooper, 1956, pl. 139, figs. 23-36)

\section{BLOCKHOUSE SHALE}

The Blockhouse Shale (Neuman, 1955, p. 148-154) is mostly dark-gray calcareous shale, but at the base has the thin Whitesburg Limestone Member (Ulrich, 
1929, p. 2) ${ }^{7}$ and higher up the local Toqua Sandstone Member. The Blockhouse crops out in the TellicoSevier belt along the northwest edge of the report area, and in Tuckaleechee Cove (pl. 2).

\section{DESCRIPTION}

The dark shale which forms the main body of the Blockhouse is finely laminated and fissile. In the Tellico-Sevier belt the shale contains little material coarser than fine silt and weathers chocolate brown. In Tuckaleechee Cove the shale contains somewhat coarser thin silty layers and lenses of calcareous sandstone; fine mica flakes are abundant on many bedding surfaces. Here the shale weathers to more of an olive than to a chocolate-brown color.

The basal, or Whitesburg Limestone Member, is too thin to be shown separately on the accompanying geologic maps (pls. 2, 3). It is as much as 20 feet thick at Blockhouse in the Tellico-Sevier belt, but thins to 3.5 feet northeastward along the strike and to 3-5 feet in Tuckaleechee Cove; in the cove it is faulted out in many places, like the underlying Lenoir Limestone. In the Teliico-Sevier belt northeast of Mint, the Whitesburg is light-gray cobbly argillaceous limestone, much like the Lenoir Limestone, but lighter colored and more fossiliferous. Southwest of Mint it is darker, coarser, more evenly bedded, and contains many quartz grains, the occurrence of which is perhaps related to the setting in of the Toqua Sandstone Member just above. In Tuckaleechee Cove the Whitesburg is a single ledge of reddish-gray to dark-gray coarse calcarenite, formed largely of encrinal and bryozoan debris, with wavy clay seams at 2 - to 4 -inch intervals. In the Tellico-Sevier belt the Whitesburg grades into and intertongues with the overlying dark shale of the main body of the formation, except southwest of Mint, where it is succeeded abruptly by the Toqua Sandstone Member.

The Toqua Sandstone Member is differentiated in the Tellico-Sevier belt, where it extends from Mint southwestward beyond the report area (pl. 2). The Toqua is light-gray fine to coarse sandstone, composed mostly of quartz grains, which forms well-laminated to massive 4- to 20 -inch beds that weather greenish brown to olive. The Toqua Sandstone Member intertongues with the shale of the main body of the Blockhouse (Neuman, 1955, p. 151). At Mint it consists of 65 feet of thin sandstone beds lying in dark shale, the sandstone beds becoming finer grained and thinning out in

\footnotetext{
7 This usage of Whitesburg Limestone Member does not accord with that of B. N. Cooper and G. A. Cooper (Cooper and Cooper, 1946, p. 54 ; Cooper, G. A., 1956, p. 97-98), who have replaced the term beyond the immediate vicinity of Whitesburg, Tenn., with the "Fetzer tongue of the Arline formation" (Cooper, G. A., 1956, p. 64). Both at Whitesburg and in the present area the term Whitesburg applies to granular limestone containing abundant trilobites.
}

the shale northeastward and coalescing into a solid sandstone body as much as 400 feet thick southwestward. Sandstone like the Toqua, but not designated as such, occurs near the base of the Blockhouse in Tuckaleechee Cove (pls. 3, 5), where it is as much as 10 feet thick but is faulted out in many places.

At the type section of the Blockhouse Shale at Blockhouse (Neuman, 1955, p. 149), in the TellicoSevier belt, the shale occupies the whole formation above the Whitesburg Member and is 400 feet thick, consisting of dark uniform shale in the lower half, but in the upper half containing thin interbedded layers of fine-grained dark-gray limestone and petroliferous carbonate nodules. A few feet of dark shale at the top is overlain by a transitional unit 50 feet thick, in which dark shale of Blockhouse type is interbedded with light-gray silty shale of Tellico type. A sequence like that at Blockhouse persists northeastward beyond the report area (King, 1964), but southwestward the shale thickens above the Toqua Member to 900 feet near Ninemile Creek at the west edge of the report area (pl. 2). In Tuckaleechee Cove the shale is truncated above by the Great Smoky fault, and the overlying Tellico Formation is not preserved. Perhaps about 450 feet of shale occurs in the cove, but it is so crumpled and sheared that reliable measurements are impossible.

\section{Fossrrs}

The Whitesburg Limestone Member in the TellicoSevier belt contains abundant fossils, particularly brachiopods. Graptolites, including the zone marker Nemagraptus gracilis (Hall), are common in the dark shale where they are flattened and crushed and in the Toqua Sandstone Member where they are commonly not crushed.

Brachiopods from the Whitesburg Member found in the report area (Neuman, 1955, p. 153, 172, pl. 25) are--

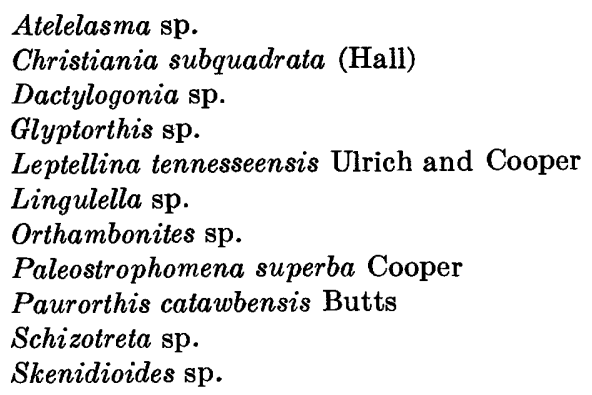

\section{TELLICO FORMATION}

The name Tellico Sandstone was originally applied (Keith, 1895) to a prominent group of sandstone beds in the Middle Ordovician sequence, but it has been redefined as Tellico Formation (Neuman, 1955, p. 154) to include silty and sandy shales above and below. In the report area thicker sandstone units are distinguished 
from the more shaly parts of the formation, but these subdivisions are not named.

\section{DESCRIPTION}

Except for a few lenticular beds of calcareous sandstone, the lower part of the Tellico is a monotonous sequence of medium-gray silty and sandy calcareous shale about 1,000 feet thick. This shale is lighter colored and more silty than that of the Blockhouse with which it is interbedded at the base. Most of the shale of the Tellico is well laminated with smooth bedding surfaces, but where it is sandy and thicker bedded, bedding surfaces are irregular. Where weathered, the shale is yellow and soft. Thin beds of calcareous sandstone occur throughout this interval, but from about 1,000 feet upward through the middle of the Tellico, sandstone is more abundant and forms mappable units as thick as 250 feet.

The sandstone is medium gray to bluish gray, fine to medium grained, in 2- to 8-inch layers separated by thin calcareous shale partings. The detrital particles are mostly fine-grained quartz; notable amounts of feldspar are found in only a few beds. Comminuted fossil debris is the principal calcareous component, but calcite also occurs as intergranular cement with some admixed argillaceous material. Individual layers are neither crossbedded nor laminated, but some beds are graded; the larger fragments of fossils are concentrated near the bases of the beds which are slightly scoured into the underlying shale partings. Every gradation occurs between sandstone and shale; the mapped sandstone units pass laterally into shaly sandstone and sandy shale vertically through interbedded sandstone and shale. Some light-gray and pink argillaceous calcarenite is interbedded with calcareous sandstone. It is composed primarily of fossil fragments, largely crinoidal, but with bryozoans, brachiopods, and less certainly identifiable organic debris, all coarsely recrystallized. The weathered sandstone is porous and dark brown. Deep-red soil with many blocks of weathered sandstone derived from the Tellico is commonly washed downslope from sandstone ridges to mantle adjacent areas that are underlain by shale.

The upper part of the Tellico is again largely calcareous shale, but it contains a zone of fossiliferous limestone cobbles about 500 feet beneath the top. The Tellico is overlain conformably by the calcarenite of the overlying Chota Formation.

\section{Fossins}

Fossils are rare in the laminated shales of the Tellico, but brachiopods and bryozoans are abundant in the limestone cobbles near its top. Calcareous sandstone and calcarenite are also fossiliferous, but the fossils are generally fragmental and poorly preserved.
Faunal lists and descriptions of collecting localities were given in an earlier report, with pictures of some of the fossils (Neuman, 1955, p. 155-157, 172-173, pl. $25)$.

The brachiopods are--

Camerella sp.

Cyrtonotella virginiensis Butts

Glyptorthis sp.

Macrocoelia sp.

Leptellina tennesseensis Ulrich and Cooper

Multicostella ef. $M$. saffordi (Hall)

Orthambonites neumani Cooper

Oxoplecia cf. O. holstonensis Willard

Paleostrophomena sp.

Paurothis catawbensis Butts

Rhipidomena tennesseensis (Willard)

Skenidioides sp.

Sowerbyella negritus (Willard)

\section{CHOTA FORMATION}

The Chota Formation was named (Neuman, 1955, p. 157) for rocks previously termed (Keith, 1895, 1896a) the "sandstone lentil of the Sevier Formation." The type locality is a little west of the report area, in bluffs overlooking the Little Tennessee River at Chota School.

The Chota is mostly calcarenite containing varying quantities of quartz grains. Quartz commonly forms as much as half the volume of the rock; but in some beds it occurs only as scattered grains, and in a few places it is virtually lacking. Most of the rock is medium gray, tinged with pink or red by minor amounts of pink calcite. Thin wavy partings of sandy, silty, and argillaceous material occur at 2- to 6 -inch intervals. Crossbedding and lower quartz content distinguish the Chota from the sandstones of the Tellico Formation.

The calcarenite is interbedded with minor amounts of gray nodular argillaceous limestone like that of the Lenoir Limestone, fine-grained pink limestone in which colonies of bryozoans have the appearance of phenocrysts, and gray calcareous shale similar to that of the Tellico Formation.

Quartz in the calcarenite increases very gradually from southwest to northeast. About 75 feet of nonquartzose calcarenite and argillaceous limestone forms the top of the formation in the southwestern part of the area, but it does not persist toward the northeast.

The Chota weathers to a yellow or reddish-brown friable sandy saprolite that in some places is contorted from slumping. Fresh outcrops lack the weathered rind characteristic of the sandy rocks of the Tellico Formation. The Chota forms a persistent ridge, somewhat smoother in contour and lower than the ridge formed by the sandstones of the Tellico Formation. 
From a maximum of 900 feet along the Tellico River, several miles to the southwest of the report area, the Chota thins to about 700 feet near the western boundary of plate 2, and to about 550 feet near the Little River on the east. Shale of the Sevier Formation overlies the Chota abruptly but conformably.

Fossirs

The Chota Formation contains abundant organic debris, but few identifiable fossils were collected from it. Brachiopods are most abundant, as indicated in the earlier report (Neuman, 1955, p. 159-160; pl. 25). Those collected in the report area are Mimella sp., Protozyga sp., and Ripidomena tennesseensis (Willard).

\section{SEVIER FORMATION}

The Sevier Formation of present usage (Neuman, 1955 , p. 160) includes only the upper half of the original unit (Keith, 1895, 1896a). Because of this emendation, little of the Sevier Formation is exposed in Sevier County, its original type area. Exposures in the southwestern half of the Tellico-Sevier belt of the report area display the full thickness of the formation and are more typical of it as it is now defined.

\section{DESCRIPTION}

The Sevier is a sequence of calcareous shale with interbedded calcareous sandstone units, the thicker of which have been mapped separately but are unnamed, overlain by the Bacon Bend Member at the top (Neuman, 1955, p. 162)

The shales of the Sevier Formation differ from those of the Tellico in that they are somewhat greener, less silty and sandy, more calcareous, and in places grade into laminated argillaceous limestone. Shale of this kind, with only a few lenticular sandstone beds, forms the lower 400 feet of the formation, and the topographic depression southeast of the ridge supported by the Chota is carved from it.

Calcareous sandstone forms a persistent unit that thickens from 75 feet on the northeast to about 500 feet at the southwest edge of the report area. It is gray, greenish gray, and reddish gray, fine grained to very fine grained. Individual beds are 2-12 inches thick; many are crossbedded, and some are ripple marked. Interbedded with these are gray, pink, and maroon calcarenite, light-gray and brownish-gray aphanitic limestone, and minor greenish and reddish-gray intraformational conglomerate with small limestone pebbles.

The overlying unit is largely shale on the northeast, but it includes a thin sandstone unit that thickens southwestward and is 500 feet thick at the southwestern edge of the report area where it is separated from the lower sandstone unit by a thin shale interval. In this area the upper sandstone also includes a tongue of maroon mudrock like that of the Bays higher in the sequence.

The Bacon Bend Member at the top of the Sevier Formation consists of calcareous shale and sandstone like that in the main body of the formation, but many of its beds contain contorted bedding structures (Neuman, 1955, p. 163, pl. 26) that characterize the member. It also contains red laminated mudrock and impure limestone similar to the red rocks of the Bays Formation. The member is about 90 feet thick at its type locality near the Little Tennessee River where sandstone and red mudrock are abundant, but it becomes more shaly toward the northeast and thins to about 45 feet.

The Bacon Bend Member is transitional between the Sevier and the overlying Bays Formation, and the contact is placed at the lowest occurrence of nonlaminated red mudrock typical of the Bays.

\section{Fossns}

Fossils occur in the sandy beds, calcarenites, and limestones of the Sevier Formation. Brachiopods and bryozoans are locally abundant in the main body of the formation and in the nonred rocks of the Bacon Bend Member. The red rocks of the Bacon Bend Member are rarely fossiliferous, but they yielded brachiopods in one place and gastropods at another (Neuman, 1955, p. $162,164,173-174$, pl. 25$)$.

Fossils collected in the report area, following the nomenclature of Cooper (1956), are (Cooper's illustrations referred to are of specimens taken from this area)-

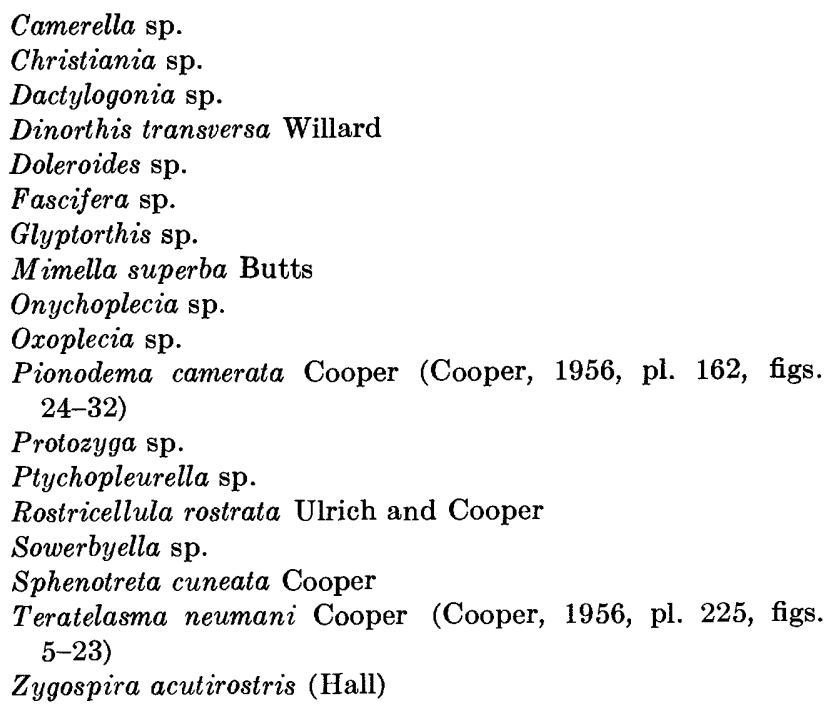

\section{BAYS FORMATION}

The Bays Formation (Keith, 1895, 1896a ; Rodgers, 1953 , p. 81-82; Neuman, 1955 , p. 164) crops out in the southwestern part of the Tellico-Sevier belt, but is truncated northeastward by the Guess Creek fault and 
does not reach the Little River. Most of the Bays is red calcareous mudrock and siltstone, ranging in texture from very fine to coarse silt embedded in an impalpable red matrix. Beds $1 / 2-2$ feet thick are massive where fresh, but closely spaced laminations are brought out by weathering.

The lower half of the formation is a nearly uniform sequence of these rocks, a few of which contain linguloid brachiopods and other fossils. The upper half contains minor interbeds of buff-colored mudrock. Toward the top the rock is coarser grained, and gray feldspathic and quartzitic sandstone is interbedded with red fine-grained sandstone. As much as 100 feet of light-gray quartzite without red interbeds at the top of the Bays at four places (see Blockhouse quadrangle, Neuman and Wilson, 1960, and Neuman, 1955, pl. 28) resembles the Clinch Sandstone and was mistaken for it earlier (Keith, 1895, p. 4).

Weathering does not alter the color of the red rocks, and weathered rock and soil of the Bays are all the same color. The red color also stains and largely masks nonred beds, but the quartzite at the top is generally revealed by large angular float blocks. The Bays outcrop belt is marked by a line of low ridges that are generally lower than those of the Middle Ordovician sandstone units to the northwest.

The Bays is overlain disconformably by the Chattanooga Shale of Late Devonian age (Hass, 1956). The contact thus marks a hiatus representing Late Ordovician, Silurian, and most of Devonian time. The lack of continuity of the quartzite at the top of the Bays may be due to erosion along the unconformity.

The rare fossils in the Bays Formation include ostracodes, linguloid brachiopods, and pelecypods. This association, interpreted to indicate an environment that was occasionally drained (Neuman, 1955, p. 165), contrasts sharply with the more normal marine assemblages below.

\section{TELLICO FORMATION AND BLOCKHOUSE SHALE,} UNDIFFERENTIATED

Between the Guess Creek and Great Smoky faults are calcareous shale, calcareous sandstone, and calcarenite like those of the Middle Ordovician Series in the Tellico-Sevier belt and in Tuckaleechee Cove, with a few fossils that verify this comparison. The intense deformation of these rocks prohibits differentiation of the subdivisions that were made elsewhere. Most of the shales are closely folded and sheared and have slickensided surfaces. The more massive sandstones are closely jointed, and thin-bedded sandstones have been broken into discontinuous pods enveloped in shale.

Through most of the report area the Middle Ordovician rocks above the Guess Creek fault are separated from those of the Tellico-Sevier belt by a broad belt of rocks of Mississippian age. Farther northeast, where the Mississippian is missing, the rocks of the two Ordovician belts can be separated only approximately.

The belt of these deformed rocks lies low on the slopes of Chilhowee Mountain and is widely covered by surficial deposits, but exposures in creek beds and along roads and trails indicate that it is a continuous feature. At the western edge of the report area, along the Little Tennessee River (inset map, pl. 2), rocks of the belt are well exposed at the mouth of Harrison Branch where they are gray silty calcareous shale, and reddish-gray calcareous sandstone and calcarenite like those of the middle part of the Tellico Formation. Farther northeast, dark- to medium-gray commonly silty shale that weathers brown and yellow-brown in smaller exposures are like the Blockhouse Shale and the shales of the Tellico Formation. In the Kinzel Springs quadrangle (pl. 3), where the outcrop belt is broader, shales with Climacograptus sp. and thinbedded silty sandstone are like some beds of the Blockhouse Shale.

Along the Little River in the northwestern part of the belt, the argillaceous sandstone in one place-creek bed, 0.3 mile southeast of Walker Cemetery, on the east side of the Little River, plate 3-contains the brachiopods Sowerbyites lamellosus Cooper and Leptellina; in other places nearby it contains Christiania and Dinorthis. The sandstone thus can be correlated with the Tellico Formation (Neuman, 1955, pl. 25).

Farther southeast, about 1,500 feet northwest of the trace of the Great Smoky fault along the west bank of the Little River, a limestone pebble bed was exposed before construction of the highway. This bed contains rounded limestone pebbles as much as 1 inch in diameter in a silty matrix. Most of the pebbles are light-gray aphanitic limestone like that of the Mosheim Member of the Lenoir Limestone and parts of the Jonesboro Limestone, but some are quartzose limestone that is very rare in rocks younger than the Jonesboro. Middle Ordovician conglomerates containing limestone pebbles occur in several places farther northeast and southwest (Kellberg and Grant, 1956), largely at the level of the Tellico Formation, but none are known elsewhere in the report area. In new cuts on Tennessee Highway 73 , deformed calcareous shale containing thin beds of silty calcareous sandstone is like that farther southwest in the belt. Some beds contain abundant linguloid brachiopods and graptolites of the genera Climacograptus, Dicellograptus, and Diplograptus; the graptolites in the sandstones are uncrushed. Near the Little River, therefore, where the belt is best exposed, its northwestern part contains 
rocks that are younger than its southeastern part. Although determination of tops of beds at individual outcrops was rarely possible, the apparent stratigraphic order and the erratic occurrence of wedges of Jonesboro Limestone to the southeast suggest that the structure of the belt is a much-attenuated limb of an overturned syncline.

\section{CORRELATION OF MIDDLE ORDOVICIAN SERIES}

Correlation of the formations of the Middle Ordovician Series, complicated by intricately interwoven facies, has long been debated by many authors. In the southern Appalachians, stratigraphic sequences differ from one outcrop belt to the next, and even within the same outcrop belt, formations grade laterally into others. Many local formations have been created, but correlation of these formations with those elsewhere has been uncertain.

Correlation of the rocks of the Tellico-Sevier outcrop belt has been treated by Ulrich (1911), Rodgers (1953, p. 64-69), Twenhofel and others (1954), Neuman (1955), and G. A. Cooper (1956, p. 38-99). Cooper's work is the most complete and is supported by intensive study of the brachiopods. His correlations of the formations of the Tellico-Sevier outcrop belt with nearby outcrop belts, the formations of Tazewell County in southwestern Virginia (Cooper, B. N., and Prouty, C. E., 1943), and the type area for North America in New York, are shown in figure 7, together with the stages into which Cooper divided this interval.

The Tellico-Sevier belt contains no correlatives of Cooper's Whiterock and Ashby stages, but the sequence here is more complete than that preserved in New York. Equivalents of the New York Chazy (Marmor stage of Cooper) are limestones in southeastern outcrop belts in Tennessee and residual rubble and clastic rocks toward the northwest. Rock relations in Cooper's Porterfield stage are more complex. The Blockhouse and Tellico of this report, the Athens in its type area, and Cooper's Paperville are dominantly clastic rocks; whereas the Whitesburg and Cooper's Arline, the Fetzer tongue of the Arline, and Prouty's (1946, p. 11561157) Farragut, exposed in belts to the west and southwest, are limestones, as are the Ward Cove, Peery, and Benbolt of Cooper and Prouty (1943) in Tazewell County, Va. Similarly, the Sevier of the Tellico-Sevier belt passes into limestones on the northwest, but its shaly rocks extend farther west than do those of the Tellico. Clastics continue to spread westward, forming the red silty rocks of the Moccasin that are correlated with the Bays Formation. These correlations confirm the presence of a rising southeastern land area during Middle Ordovician time.

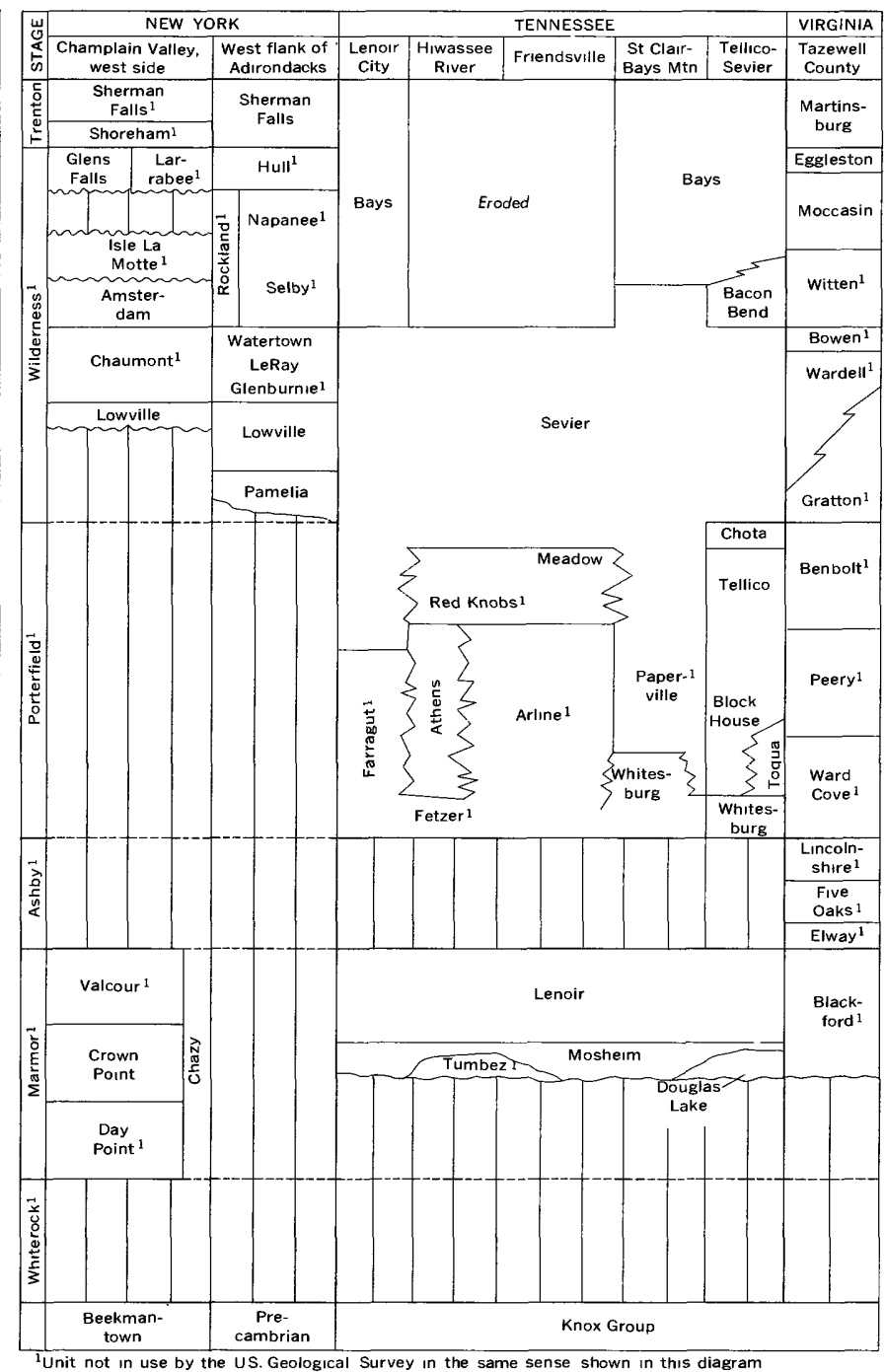

Figure 7.-Correlation of Middle Ordovician rocks of the TellicoSeiver belt, modified from G. A. Cooper (1956).

\section{DEVONIAN SYSTEM \\ UPPER DEVONIAN SERIES CHATtanooga ghaLE}

The thin shale which overlies the Bays Formation has long been classed as the Chattanooga Shale (Hayes, 1891, p. 143) and was recognized to crop out in this area by Keith $(1895,1896 a)$.

The Chattanooga Shale follows a topographic sag along the northwest side of Little Mountain and Short Mountain, and to the southwest almost reaches the Little Tennessee River (pl. 2). Exposures are rare and in most places are concealed by colluvium from higher ground on the southeast.

The Chattanooga is dark-gray brown-weathering carbonaceous noncalcareous shale, without sand or coarse silt except in the basal few inches. Laminations about $2 \mathrm{~mm}$ thick occur through much of the forma- 
tion, and beds as much as 1 inch thick without laminations are rare. At the base are a few inches of dark fine-grained sandstone; in the upper half, rust-coated concretions are common.

Deformation has disrupted the formation in most exposures into small pods whose boundaries are polished and slickensided.

Many small prospect pits have been dug into the Chattanooga in the belief that it is coal. The best exposure of the formation is one of these pits, in the western part of the area (Pumpkin Center of pl. 2, in an unnamed creek 0.4 mile northeast of the junction of Tennessee Highway 72 with U.S. Highway 129). Here the Chattanooga rests on quartzite of the Bays Formation, and the basal sandy bed is 5 inches thick. The dark shale is about 25 feet thick and is overlain sharply by lighter colored platy siltstone of the Grainger Formation.

The only fossils collected are conodonts and small linguloid brachiopods. Hass (oral commun., 1955) recognized palmatolepid conodonts like those of the Gassaway Member farther west (Hass, 1956, p. 20) in samples from about the middle of the formation at the Pumpkin Center exposure. About 3 miles southwest of Pumpkin Center, Glover (1959, p. 145) found two black shales separated by siltstone that contains marine megafossils of Early Mississippian age; conodonts in the overlying black shale are also of Early Mississippian age, but no fossils were identified from the lower black shale here. The occurrence of black shales with Mississippian fossils suggests that some of the black shale of the present area may not be of late Devonian age, and hence not Chattanooga in the sense of Hass and others.

\section{MISSISSIPPIAN SYSTEM}

\section{LOWER MISSISSIPPIAN SERIES}

GRAINGER FORMATION

The Grainger Formation, originally called Grainger Shale, is named for Grainger County, Tenn. (Campbell, 1893 , p. 38 ; Keith 1896 b, p. 3 ). In its type area it consists of shale and sandstone between the Chattanooga Shale and Newman Limestone. In the folio reports the Grainger was classed as Devonian in age, but Ulrich (in Burchard, 1913, p. 152) and later geologists have shown that it is of Early Mississippian age. Within the present report area Safford (1869, map) was the first to observe Carboniferous rocks along the northwest flank of Chilhowee Mountain.

\section{DESCRIPTION}

The lower three-fourths of the Grainger is a monotonous sequence of gray and blue-gray noncalcareous siltstone and fine-grained sandstone that is nearly mas- sive in unweathered exposures. On weathering some of it becomes shaly, but slabby uneven bedding is most common. Such rock forms units 1-11 of geologic section 4 (p. D42) where the Grainger is about 900 feet thick.

The upper part of the formation is coarser grained and thicker bedded. Fine to coarse-grained dull-gray to blue-gray feldspathic sandstone in 2- to 3-foot beds that are commonly crossbedded is most abundant, with interbedded layers of pebble conglomerate $1 / 2-2$ feet thick containing $1 / 2$ - to 1 -inch rounded quartz pebbles. A few beds in this part of the sequence, and more rarely below, are fossiliferous ferruginous sandy limestone, commonly deeply weathered, that has been prospected for iron ore (Burchard, 1913, p. 151-154). The coarser grained sandstone and conglomerate, beds which are concentrated at two levels (units 12 and 16, geologic section 4) and separated by silty shale and fine-grained sandstone, make a double crest on Little and Short Mountains. Where measured, this part of the Grainger is about 200 feet thick. Its top, and the boundary with the overlying Greasy Cove Formation, is placed at the top of the highest conglomeratic sandstone, but medium to fine-grained sandstone like that of the Grainger persists into the Greasy Cove Formation.

\section{FOSSIUS, AGE, AND CORREIATION}

Marine fossils are abundant in several layers of sandstone and conglomerate in the upper fourth of the Grainger. They include brachiopods, bryozoans, pelecypods, and other forms. The remainder of this formation contains few fossils other than plant fragments and, more rarely, markings that have long been given the name Taonauris.

A large collection was made from sandy beds in the upper part of the formation, probably at the level of units 11 and 12 of geologic section 4 (p. D43), from a roadcut 1.5 miles northwest of Montvale Springs (USGS upper Paleozic loc. 12078) by the late J. S. Williams, Mackenzie Gordon, Jr., and others. Gordon's identifications (written commun., 1951) are listed below:

Coral: Cladochonus? sp.

Bryozoans:

Fenestella, 2 or more indet. species

Polypora sp. indet.

Sulcoretepora sp. indet.

Stenoporoid bryozoans

Rhomboporoid bryozoans

Crinoid columals and plates

Brachiopods:

Orthotestes cf. $O$ keokuk (Hall)

Setigerites setiger (Hall)

Ovatia pileiformis (McChesney)? 
Brachiopods-Continued

Echinoconchus biseriatus (Hall)

Beecheria sinuatum Weller, var.

Punctospirifer, 2 sp.

Spirifer, $2 \mathrm{sp.}$

Echinocoelia? sp.

Torynifer pseudolineatus (Hall)

Athyris lamellosa (Levielle)

Pelecypods:

Lithophagus? illinoiensis Meek and Worthen

Pinna cf. P. subspatulata Worthen

Limipecten sp.

Nuculana? sp.

Conocardium sp. indet.

Cypricardinia? sp. indet.

Sphenotus sp.

Sphenotus? sp.

Edmondia sp.

Allerisma sp.

Conularids:

Conularia sp.

Conularia? sp. indet.

Gastropod:

Bembexia? sp. indet.

Trilobites:

Griffthides sp.

Proetides? sp. indet.

Fish scale

Plant fragment

Gordon suggests that these beds are equivalent to the upper part of the Price Formation or the Maccrady of southern Virginia and the Keokuk Limestone of the Mississippi Valley basin, although the productids from the Grainger "are common in beds of Warsaw age in southwest Missouri and northern Oklahoma $* * *$ [where] they are associated with other species."

The fourfold subdivision of the Grainger Formation in the Greendale syncline (Sanders, 1952) about 70 miles north of the present area, cannot be recognized here. Although the total thickness of the formation in the two areas is comparable, sandstone and conglomerate are more abundant in the present area at the expense of shale and siltstone.

\section{UPPER MISSISSIPPIAN SERIES}

GREASY COVE FORMATION

The Greasy Cove Formation, was named for Greasy Cove, a valley between Little Mountain and Chilhowee Mountain northeast of Butterfly Gap (pl. 2 Blockhouse quadrangle, Neuman and Wilson, 1960), and a type section was designated along a small creek southeast of Butterfly Gap (geologic section 4). The Greasy Cove corresponds approximately to the Newman Limestone as mapped by Keith $(1895,1896 a)$, although the base is here placed at a somewhat lower level. The new name was necessary because of the many differences between it and the Newman Limestone 65 miles to the northeast (Keith, 1896b), which consists of relatively pure limestone.

\section{DESCRIPTION}

Easily weathered shale and limestone form much of the Greasy Cove Formation, resulting in its common concealment beneath debris from Chilhowee Mountain. Most outcrops are along creekbeds.

The Greasy Cove Formation is a sequence of intimately interbedded gray argillaceous limestone, calcareous gray shale and fine-grained sandstone, and red shale and sandstone. The limestone occurs in beds as thick as 4 feet that include thin shelly layers at 2- to 6 -inch intervals and some coarse-grained calcarenite. Its weathered residuum is yellow, waxy clay, compact where there are no fossils, but with open space where fossils have been dissolved away. Greasy Cove probably owes its name to the texture of this material.

Interbedded with the limestone are light-red shale, siltstone and feldspathic sandstone, and greenish-gray argillaceous siltstone and fine-grained sandstone. The nonred siltstone and sandstone are indistinguishable from many beds in the Grainger, but the red rocks are distinctive of the Greasy Cove. These range in grain size from the impalpable shale to coarse-grained sandstone. Sandstone beds are seldom more than 6 inches thick, although units of red rock including a wide range of textures are as much as 50 feet thick. These rocks are not calcareous, and weathering usually reduces them to small chips and blocks which are common in the overlying residual soils.

Only the lower beds of the formation are adequately exposed, and a section including them and the underlying Grainger Formation was measured (geologic section 4). Although it is incomplete, it is the best sequence of exposures in Greasy Cove and is thus designated as the type section of the Greasy Cove Formation.

Geologic Section 4.-Mississippian rocks at Butterfly Gap through Little Mountain

(pl. 2; also Blockhouse quadrangle, Neuman and Wilson, 1960)

[Top of measured section in small creek about 500 feet southeast of road forks at east end the road forks at the west end of the gap]

Unit

Description

Thickness

Greasy Cove Formation (type section; about $400 \mathrm{ft}$

exposed, of which $178.5 \mathrm{ft}$ is described below)

46. Shale, gray, finely laminated...

45. Sandstone, fine-grained, weathered, yellowbrown...-.....

44. Shale, weathered, brownish-gray, finely lami-

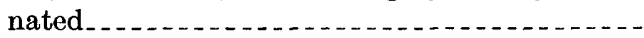

43. Sandstone, weathered, yellow-brown, finegrained; contains fragments of bryozoans...

42. Shale, gray, waxy, weathered....

41. Limestone, argillaceous, gray, platy; without fossils.

2

40. Covered

39. Limestone, argillaceous, gray, platy, laminated; brachiopods and pelecypods.................... 
Greasy Cove Formation-Continued

Unit Description

38. Mostly covered; red shale about $1 \mathrm{ft}$ thick $10 \mathrm{ft}$ above base of interval ............

37. Sandstone, fine-grained, weathered, yellowbrown; beds 6-10 in. thick. . . . . . . . . . .

36. Covered

35. Limestone, gray, fine-grained, platy; mostly finely laminated and unfossiliferous, but nonlaminated layers 1-2 in. thick contain brachiopods and other fossils (see list below, USGS upper Paleozoic loc. 16571) ..............

34. Covered_............

33. Sandstone, gray, fine-grained; weathered brown.

32. Sandstone, gray-brown, fine-grained; contains small plant fragments.................

31. Shale, gray, finely laminated; with a few sandy beds; weathers brown....................

30. Limestone, gray, fine-grained, argillaceous; weathers into yellow plates; 2 beds, each $2 \mathrm{ft}$ thick, separated by covered interval $3 \mathrm{ft}$ thick -

29. Sandstone, maroon, fine-grained, platy ........

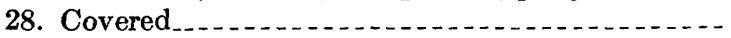

27. Sandstone, fine-grained, feldspathic, weathered, yellow-brown ..........................

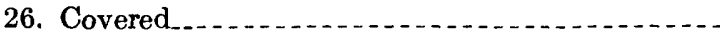

25. Shale, gray, weathered, waxy

24. Shale, red, finely laminated ..............

23. Shale, light-brownish-gray, sandy; contains a few small plant fragments.

22. Shale, light-gray, micaceous; contains small

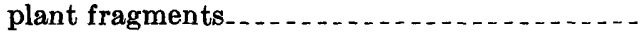

21. Covered

20. Sandstone, fine-grained, maroon and dark-brown.

19. Sandstone, gray-brown, fine-grained, feldspathic; in beds about $1 \mathrm{ft}$ thick; weathers brown.....

18. Shale, weathered, yellow, waxy; contains brachiopods and bryozoans. .....................

17. Covered interval, covering contact with Grainger Formation, about ..............................

Grainger Formation (about 1,050 ft):

16. Sandstone, medium- to coarse-grained, feldspathic, brownish-gray; 2 beds of conglomerate containing pebbles of quartz as much as $1 \mathrm{in}$. in diameter.

15. Sandstone, fine to medium-grained, brownishgray, feldspathic

14. Shale, gray; silty with coaly flecks; and finegrained thin-bedded sandstone...........

13. Sandstone, silty, calcareous, dark-blue-gray; contains brachiopods, pelecypods, and bryozoans.

12. Sandstone, blue-gray, medium- to coarse-grained, feldspathic; 2 beds of conglomerate, each about $2 \mathrm{ft}$ thick, one near the base, the other about $30 \mathrm{ft}$ higher; the sandstone beneath the bigher conglomerate bed is calcareous and where weathered, is ferruginous. ................

11. Sandstone, blue-gray, feldspathic and argillaceous, medium-grained; bedding irregular and poorly defined; forms cascades in creek........

10. Sandstone, fine-grained, silty, calcareous; contains thin pebble beds; the more calcareous beds contain brachiopods and bryozoans......

Grainger Formation-Continued

Unit Description

9. Sandstone, fine-grained, and siltstone, bluegray; thin-bedded where fresh, weathers to irregular plates; iron stained...............

8. Sandstone, maroon, hematite-cemented; contains concretionary limonite ..................

7. Sandstone, light-gray, fine-grained, silty; shaly

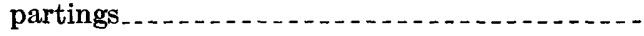

6. Sandstone, blue-gray, fine-grained; poorly de-

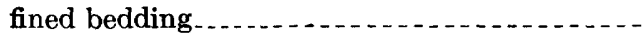

5. Covered

4. Sandistone, blue-gray, fine-grained, silty, thin-

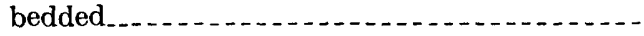

3. Shale, and sandy shale, gray, thin-bedded......

2. Shale, gray, fissile; contains specks of carbonaceous material.

Thickness ( feet)

46

50

50

52

1. Shale, dark-gray, fine-grained; contains small black ellipsoids about $5 \mathrm{~mm}$ in diameter; contorted; may belong to the Chattanooga shale..

27

18

10

3

7

1

1

4

5

12

13

5

3

200

19

75

12

45

97

62

\section{Chattanooga Shale at base.}

The top of the Greasy Cove is faulted off. Although it may have been overlain by younger Mississippian and Pennsylvanian formations, as are its equivalents to the northwest, the Greasy Cove was possibly the youngest formation deposited in the area.

\section{FOSSILS, AGE, AND CORRELATION}

Fossils, dominantly brachiopods, are common in many of the limestone layers in the Greasy Cove Formation but are virtually lacking in the other rocks of the formation. In the limestones the shells are most commonly concentrated in shell beds. Spirifer bifurcatus Hall, Brachythyris subcardiformis (Hall), Composita trinuclea (Hall), and an undescribed form closely related to Setigerites altonensis (Norwood and Pratten) in the Greasy Cove indicate its Warsaw age (early Late Mississippian) (Gordon, written commun., 1957). Gordon identified the following fossils from 6 collections :

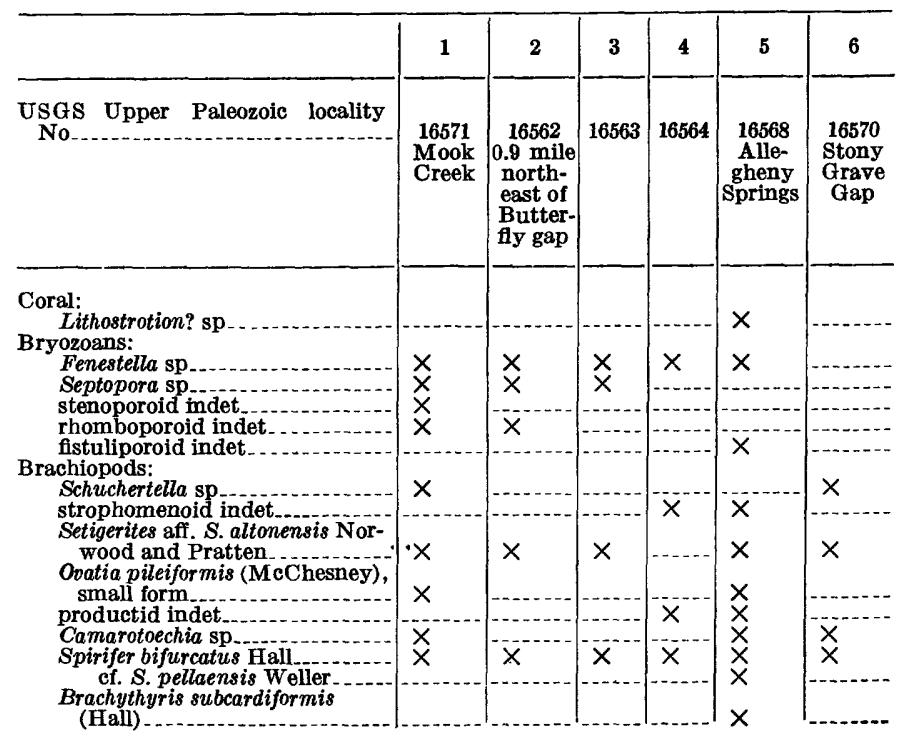




\begin{tabular}{|c|c|c|c|c|c|c|}
\hline & 1 & 2 & 3 & 4 & 5 & 6 \\
\hline USGS Upper Paleozoic locality No. & $\begin{array}{l}16571 \\
\text { Mook } \\
\text { Creek }\end{array}$ & $\begin{array}{c}16562 \\
0.9 \text { mile } \\
\text { north- } \\
\text { east of } \\
\text { Butter- } \\
\text { fy gap }\end{array}$ & 16563 & 16564 & $\begin{array}{c}16568 \\
\text { Alle- } \\
\text { gheny } \\
\text { Springs }\end{array}$ & $\begin{array}{l}16570 \\
\text { Stony } \\
\text { Grave } \\
\text { Gap }\end{array}$ \\
\hline \multicolumn{7}{|l|}{$\begin{array}{l}\text { Brachiopods-Continued } \\
\text { Composita trinuclea (Hall) }\end{array}$} \\
\hline $\begin{array}{l}\text { sp- } \\
\text { Cleiothyridina sp- }\end{array}$ & & $x$ & & $x$ & $x$ & $x$ \\
\hline Torynifer sp......- & & & & $\cdots$ & \multirow{2}{*}{$\begin{array}{l}x \\
x\end{array}$} & … \\
\hline $\begin{array}{l}\text { Punctospirifer? sp } \\
\text { spiriferinid indet }\end{array}$ & $x$ & & $\ldots$ & \multirow[t]{2}{*}{$x$} & & \multirow[b]{2}{*}{$x$} \\
\hline Eumetria verneuilliana (Ha) & & & & & & \\
\hline Girtyella $\mathbf{s p}^{\mathbf{s p}}$ & & $x$ & -.... & $\cdots$ & \multirow{3}{*}{$\stackrel{x}{x}$} & $\ldots \ldots$ \\
\hline \multirow{2}{*}{\multicolumn{6}{|c|}{$\begin{array}{l}\text { Pelecypods: } \\
\text { Lima sn }\end{array}$}} & ....... \\
\hline & & & & & & \\
\hline Myalina sp........ & & & & \multirow{2}{*}{$x$} & \multirow[t]{2}{*}{$x$} & \\
\hline Sulcatopinna sp.-....... & \multirow{2}{*}{$x$} & $\stackrel{x}{x}$ & $\cdots-\cdots$ & & & ......- \\
\hline $\begin{array}{l}\text { Pinna } \mathrm{sp}_{-} \\
\text {Leptodesma sp........ }\end{array}$ & & & ........ & \multirow{3}{*}{$\begin{array}{l}x \\
x \\
x\end{array}$} & & \\
\hline Aviculopecten $\mathrm{sp} . . . .$. & $x$ & - & -.--.-- & & & $\ldots$ \\
\hline $\begin{array}{l}\text { pectenoid indet. } \\
\text { pect..... }\end{array}$ & & $\ldots$ &.-- & & \multirow{2}{*}{$\begin{array}{l}x \\
x\end{array}$} & ....... \\
\hline Solenomya? sp & \multirow{3}{*}{$x$} & & $\cdots$ & $\cdots$ & & -......- \\
\hline $\begin{array}{l}\text { Parallelodon sp........ } \\
\text { Allerisma } \mathrm{sp}\end{array}$ & & & & & \multirow{2}{*}{$x$} & \\
\hline \multirow{2}{*}{\multicolumn{2}{|c|}{ Gastopods: }} & & $-\ldots$ & $\ldots$ & & - \\
\hline & & $x$ & & & \multicolumn{2}{|l|}{$x$} \\
\hline $\begin{array}{l}\text { Straparofous? } \\
\text { Platyceras? } \mathrm{s} \text {. }\end{array}$ & & & $x$ & & $\lambda$ & \\
\hline Griffithoides sp. & & & & & $x$ & ........ \\
\hline
\end{tabular}

Collections:

1. Unit 35 of geologic section 4, type section of the Greasy Cove Formation.

2. Blockhouse quadrangle, Greasy Cove, 0.9 mile northeast of Butterfly Gap, in creek bank at the mouth of a small tributary from the south.

Blockhouse quadrangle, foot of Chilhowee Mountain, 0.5 mile northwest of $1,410 \mathrm{ft}$ altitude.

4.

5. Tallassee quadrangle, 0.8 mile northwest of Allegheny Springs, roadside

outcrops. Grave Gap.

In addition, I. G. Sohn (written commun., 1955) identified the following ostracodes from USGS upper Paleozoic loc. 16571.

Graphiadactyllis n. sp.; differs from $G$. axea Brayer from the Salem Limestone in absence of posterior spines and in shorter frill

Graphiadactyllis? sp.

Glyptopleura? sp.

Parparchites sp. (1 specimen)

Indeterminate genus, bisulcate, velate

Indeterminate genus, smooth

Correlation with the formations recognized by Sanders ${ }^{8}$ (1953) in the Greendale syncline is hazardous on the basis of present knowledge. Sanders distinguished the Maccrady Formation, about 65 feet thick, of red shale and sandstone, overlain by the Little Valley Formation of limestone and minor amounts of siltstone and sandstone, 150 feet thick in the Pressmens Home area, but as much as 600 feet thick to the northeast (Averitt, 1941, p. 17). Above the Little Valley is a sequence of cherty limestone, siltstone, and noncherty limestone, about 330 feet thick, the Hillsdale Limestone (St. Louis Limestone of Butts, 1940, p. 359; Sanders, 1953). The red rocks of the Greasy Cove

\footnotetext{
${ }^{8}$ Sanders, J. E., 1962, Geology of the Pressmen's Home area, Hawkins and Grainger Counties, Tenn.: Doctor of philosophy dissertation, Yale Univ. Available from Tennessee Dept. Conserv., Div. Geology, Nashville, Tenn.
}

suggest correlation with the Maccrady, but that formation is not known to contain gray fossiliferous limestone as well. The Maccrady has been correlated with the Keokuk and Warsaw Limestones (Weller, and others, 1948), the Little Valley with the Warsaw, and the Hillsdale with the St. Louis Limestone. The latter correlation was based on Lithostrotion (Butts, 1940, p. 365), present also in the Greasy Cove, but facies control of faunas (Sanders, 1953) seems to complicate the picture.

\section{GREASY COVE AND GRAINGER FORMATIONS, UNDIFFERENTIATED}

The Greasy Cove Formation is bordered on the southeast by a reverse fault beyond which is another belt of Mississippian rocks forming a disordered mass that contains virtually every rock type known from the more orderly outcrop belt to the northwest. CConglomerate and sandstone like the Grainger Formation are most abundant, but there are minor amounts of limestone like the Greasy Cove and shales like the Chattanooga. Intense deformation is indicated by the inconstancy of these rocks; adjacent traverses across the belt revealed altogether different sequences, and even the most competent units could be traced for only short distances. This unit is tectonic rather than stratigraphic, but it is expedient for mapping.

Dark shale like the Chattanooga occurs in several places at the southeastern edge of the belt, and Grainger rock types dominate in the northwestern part, pointing toward an overturned succession. Few exposures give direct evidence of overturning, suggesting that an intricate system of faults has produced the apparent inversion; but an obviously inverted sequence was followed for several hundred feet in the Tallassee quadrangle about 2.5 miles northeast of Allegheny Springs (pl. 2), where feldspathic quartzite like that of the upper part of the Bays Formation is overlain on the northwest by black shale of the Chattanooga.

Old prospect pits in several places in the Kinzel Springs (pl. 3) and Blockhouse (Neuman and Wilson, 1960) quadrangles expose hematitic rock like that in the Grainger to the northwest. Fossils from one of these pits are also like those of the Grainger, according to Gordon (written commun., 1951).

USGS upper Paleozoic loc. 1207\%. Kinzel Springs quadrangle, prospect pit, 0.4 mile west of Bench Mark at 2,807 feet on top of Chilhowee Mountain

[Collected by J. S. Williams, MacKenzie Gordon, Jr., and others; identifications of corals and bryozoans by Helen Duncan, written commun., 1951; other fossils identified by Gordon, written commun., 1951]

Coral:

"Zaphrentoid" coral, genus and species indeterminate, but with the general size and shape of Hapsiphyllum cassedayi (Milne Edwards and Haime) 
USGS upper Paleozoic, etc.-Continued Bryozoans:

Fenestella, several indet. species

Polypora sp. indet.

Rhomboporoid bryozoans

Brachiopods:

Productus (Setigerites) setiger Hall

Camarotoechia or Rhynchopora sp.

Spirifer sp.

Syringothyris? sp.

?Ptychospira sexplicata (White and Whitfield)

Orthorhynchia sp.

Crinoid columnals

Platycrinid columnals

\section{STRUCTURAL GEOLOGY}

The western part of the Great Smoky Mountains and their foothills to the north are split into five major blocks by four major thrust faults (pl. 2). Each block contains a sequence of rocks which differs in varying degrees from the sequences of the adjacent blocks. Between some blocks, such as the Chilhowee and those which adjoin it, the relative stratigraphic position of the sequences involved can be fairly well established. Between others, where the rocks of the Ocoee Series are involved, stratigraphic relations are obscure, and relative displacements along the faults are difficult to determine.

In the foregoing sections of this report the rock units were described in the approximate order of their appearance on these structural blocks. In this section the structure of the blocks and important features of the faults that separate them are described. The major structural elements are-

1. Rocks beneath the Great Smoky fault

A. Syncline to the north of Chilhowee Mountain

B. Guess Creek fault

C. Rocks between the Guess Creek and Great Smoky faults

D. Overridden rocks of the windows

2. Great Smoky fault

3. Chilhowee Mountain block

4. Miller Cove fault

5. Rocks between Miller Cove and Rabbit Creek faults

6. Rabbit Creek fault

7. Rocks between Rabbit Creek and Oconaluftee fault

8. Oconaluftee fault

9. Rocks above Oconaluftee fault

These structures are shown on the accompanying sections. Those of plate 3 are spaced at 1-mile intervals and are continuations of structure sections drawn by King (1964, pl. 9) of quadrangles adjacent to the east and southeast. In addition, a structure contour map (pl. 6) of the Great Smoky fault complements an adjoining similar map by King (1964, pl. 12).

\section{ROCKS BENEATH GREAT SMOKY FAULT}

SYNCLINE NORTH OF CHILHOWEE MOUNTAIN

The Middle Ordovician rocks of the Tellico-Sevier belt and the overlying Mississippian rocks are part of a deep syncline whose limb extends southeastward from outside the report area to its faulted boundary on the southeast (Blockhouse quadrangle, Neuman and Wilson, 1960; Maryville quadrangle, Cattermole, 1962). It is composed of a sequence more than 12,000 feet thick, extending from Middle Cambrian (Maryville Limestone) through Late Mississippian (Greasy Cove Formation). Through most of the Valley and Ridge province in Tennessee, the youngest rocks preserved are of Middle or Late Ordovician age; only four other synclines are sufficiently deep to preserve rocks of Mississippian age at present erosion levels (Rodgers, 1953).

Through most of the present area the rocks on the northwest limb of this syncline are nearly homoclinal, with dips $35^{\circ}-55^{\circ} \mathrm{SE}$. and strikes $40^{\circ}-70^{\circ} \mathrm{NE}$. The southeastern limb of the syncline has been virtually destroyed; what remains are the greatly disturbed rocks associated with the Guess Creek and Great Smoky faults, discussed separately (p. D47). At the western edge of the map area (pl. 2) curving strikes of the Grainger and Greasy Cove Formations in Short Mountain suggest an approach to the trough of the syncline, but there is a complementary anticline a short distance farther southeast where southeastward dips are resumed, suggesting that this is more likely a subordinate drag fold.

The homocline passes into folds toward the northeast corner of the map area (pl. 2). Here a pair of gently plunging anticlines and synclines offset Middle Ordovician outcrop belts toward the northwest, so that the outcrop of the series at the eastern margin of the map is twice as wide as farther southwest.

\section{GUESS CREFK FAULT}

Northwest of the Great Smoky fault along the northwest foot of Chilhowee Mountain is a narrow belt of greatly disturbed Middle Ordovician rocks (Otb of pls. 2 and 3). The Guess Creek fault forms the contact between these and Mississippian rocks in some places, and between these and less disturbed Middle Ordovician rocks in others (Neuman, 1951, p. 746).

The Mississippian rocks in the narrow belt on the downthrown (northwestern) side of this fault appear to be remnants of the attenuated overturned $\operatorname{limb}$ of the large syncline on the northwest. The rocks are complexly deformed and not subdivisible, but sheared Chattanooga Shale at a few places at the southeastern margin of the belt adjacent to the fault and an over- 
turned segment near Allegheny Springs suggest general overturning. The Mississippian belt is apparently separated by another fault from the Greasy Cove Formation, with more regular structure northwest of it.

The Guess Creek fault can be located within a few feet at several places where Mississippian rocks lie to the northwest. Near the Little Tennessee River (inset map, pl. 2) the belt of disturbed Mississippian rocks wedges out, and Middle Ordovician rocks above the Guess Creek fault block are thrust against a syncline formed of quartzite of the Bays Formation, the Chattanooga Shale, and the lower part of the Grainger Formation. In other places, as at Allegheny Springs and along the trail from Montvale Springs to Look
Rock (Blockhouse quadrangle, Neuman and Wilson, 1960), the contact is between contrasting weathered shales with only a few feet of covered interval between them. The only fresh exposure of the fault known is in the Kinzel Springs quadrangle (pl. 3) along Rocky Branch at 1,060 feet altitude, where crumpled darkgray shale of Mississippian age on the downthrown (northwest) side is in knife-sharp contact with medium-gray calcareous siltstone of Middle Ordovician age and dips $60^{\circ} \mathrm{SE}$.

Mississippian rocks and the upper part of the Middle Ordovician Series in the Kinzel Springs quadrangle (fig. 8) are terminated by the Guess Creek fault and, for a short distance, the fault bordering the dis-

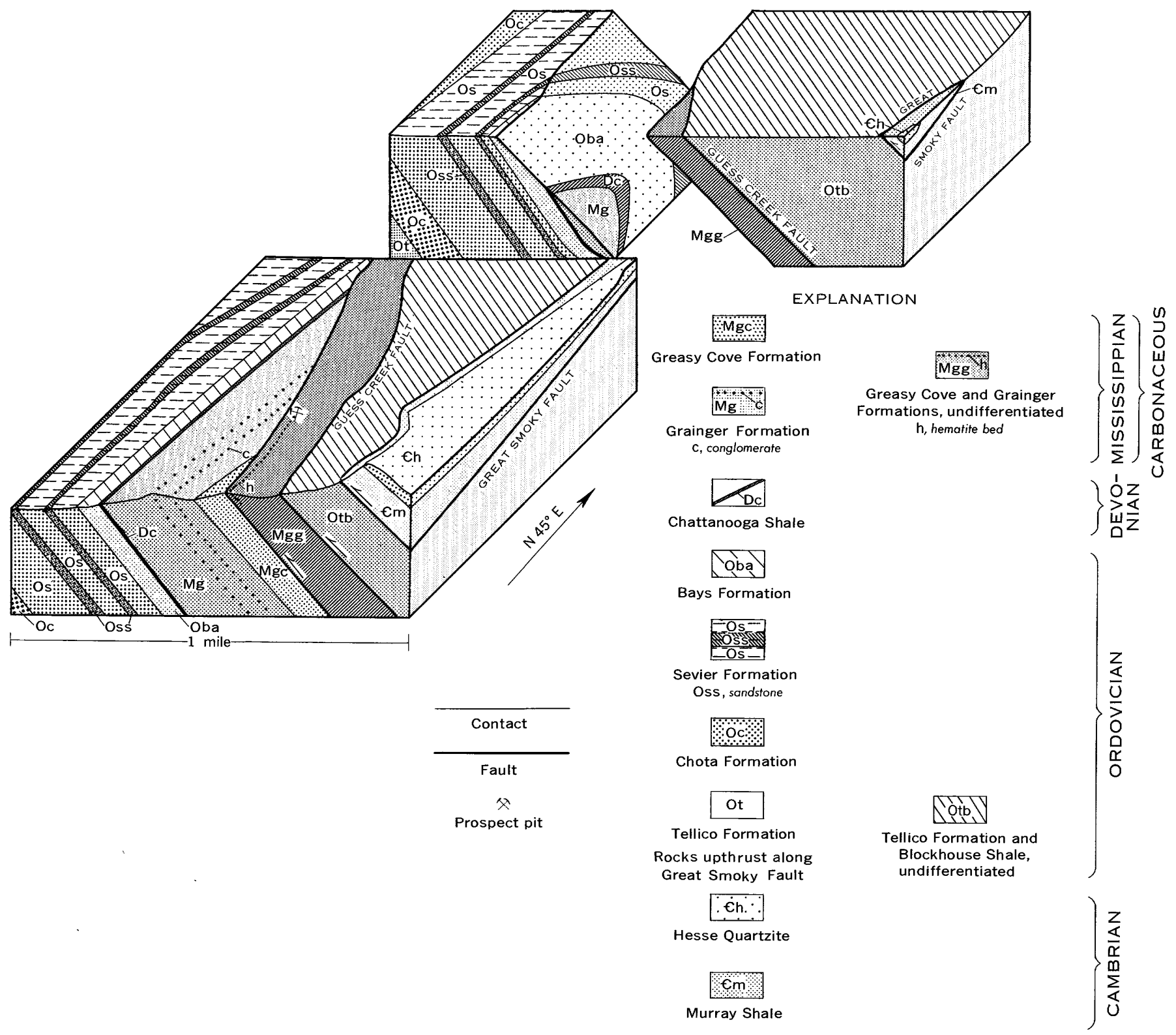

FIGURE 8.-Block diagram showing geologic interpretation at the northeast end of Mississippian outcrop belts, Kinzel Springs quadrangle. 
rupted block of Mississippian rocks. From southwest to northeast the fault that marks the northwestern boundary of the block of disrupted Mississippian rocks (mostly of the Grainger Formation) cut progressively across older formations, so that at the near end of the diagram (fig. 8) the footwall is in the Greasy Cove Formation, but 1 mile to the northwest it is in the Bays Formation. The Guess Creek fault, in turn, cuts out the belt of disrupted Mississippian rocks about half a mile beyond. From here northeastward, Mississippian rocks are not preserved, and the Guess Creek fault lies between two very similar sequences of shales and sandstones of Middle Ordovician age. The strike of the fault between the two blocks of Mississippian rocks is more northerly than that of the beds of the overridden block, and its dip probably varies between $45^{\circ}$ and $60^{\circ} \mathrm{SE}$. Toward the northeast where the fault dips less than the beds it crosses, the disrupted Mississippian rocks are thrust over the Bays Formation. The short extent of the upfaulted Mississippian rocks beyond those which have not been moved suggests that in this area the syncline had a southwestward plunge. The Guess Creek fault in this area strikes even more northerly than the unnamed fault; at Rocky Branch it dips $60^{\circ} \mathrm{SE}$., and elsewhere the dips between $45^{\circ}$ and $60^{\circ} \mathrm{SE}$. are geometrically reasonable.

The coincidence of the change of stratigraphic level of the sole of the Guess Creek fault with the disappearance of the Mississippian outcrops suggests that the Guess Creek fault has cut across the plunging trough of the major syncline to the north. Northeast of this area the footwall of the Guess Creek fault is in Middle Ordovician rocks, and the distance between it and the Great Smoky fault is several times greater than it is to the southwest.

The Guess Creek fault is concealed beneath alluvium along the Little River (fig. 9). Farther northeast it lies between rocks of Middle Ordovician age, and its location is inferred principally from contrasts in structure on opposite sides. Northeast of the report area (pl. 2), in the Walden Creek quadrangle (King, 1964), the Guess Creek fault is marked by a scarp along the valley of Guess Creek; farther on, in the Kykers Ferry quadrangle, it can be identified by intersecting topographic lineaments.

Interpretation of the Guess Creek and Great Smoky faults will be considered below (p. D54).

\section{ROCKS BETWEEN GUESS CREEK AND GREAT SMOKY FAULTS}

A complex of tectonic slices formed of the Jonesboro Limestone and parts of at least two Middle Ordovician formations lies between the Guess Creek and Great Smoky faults. Through most of the report area this belt is concealed by surficial deposits, and units can be traced beyond small outcrops in only a few places. Middle Ordovician rocks in this belt are rarely sufficiently distinctive to permit their assignment to formations; but where formations are identifiable, the young rocks crop out in the northwestern part of the belt. Moreover, lenticular slices of Jonesboro Limestone lie between Middle Ordovician shale (identifiable as Blockhouse in several places) on the northwest and rocks of the Chilhowee Group and the Sandsuck Formation on the southeast.

Shales in this belt have intense but irregular cleavage, slickensides, and polished surfaces, and the sandstones and limestones are closely jointed and veined by calcite. These disrupted rocks are well exposed in cuts along Tennessee Highway 73 (pl. 3), just to the north of the Little River gap through Chilhowee Mountain.

\section{OVERRIDDEN ROCKS OF THE WINDOWS}

Ordovician rocks in the foothills of the Great Smoky Mountains are exposed in five windows which have been eroded through the Great Smoky thrust sheet. The western half of the largest of these, Tuckaleechee Cove, and all Cades Cove and Calderwood lie in the

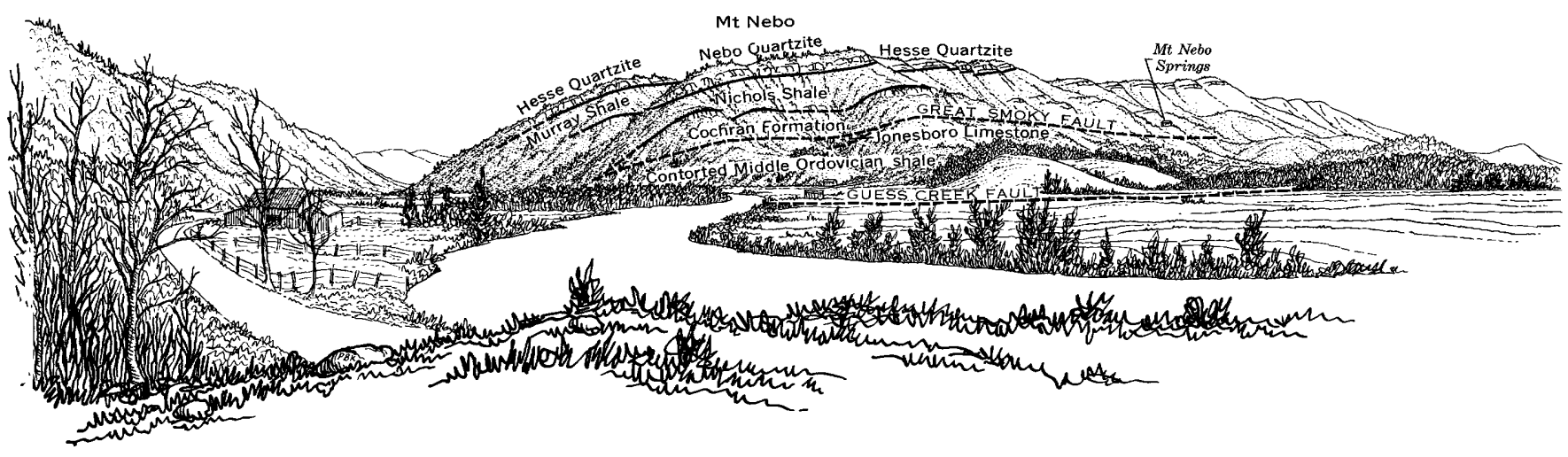

Figure 9.-Little River gap from Walker Chapel. View looking southeast from crest of ridge supported by Chota Formation. Drawing by Phillip B. King. 
report area. The eastern half of the Tuckaleechee Cove window and the Wear Cove and Big Spring Cove windows lie to the east and are reported on elsewhere (King, 1964). The Paleozoic rocks of Tuckaleechee Cove were mapped by the authors of this report, who found features in the eastern half that helped to explain relations to the west; some of these observations are included in the discussion that follows.

The rocks of the Tuckaleechee Cove window (fig. 10) consist of three structural elements: (1) a domical limestone core surrounded by (2) a mantle of shale, which is overridden in many places by (3) tectonic slices of limestone.

The domical nature of the core is shown by attitudes of the Jonesboro Limestone and by the outcrop pattern of overlying Middle Ordovician rocks, but steeply opposed dips indicate that it is complex in detail. Small-scale folds and faults are well exposed in Cedar Bluff (fig. 11), in a cliff nearly 400 feet high. The folds are broad and open, and their axial planes are nearly vertical; the faults dip gently east to southeast and are concave upward.

Around the flanks of the anticlinal core, above the Jonesboro Limestone, are limestone, sandstone, and shale of Middle Ordovician age. In most places in Tuckaleechee Cove the Jonesboro is overlain directly by shales of the main body of the Blockhouse, but in a few areas the Lenoir Limestone, including the Mosheim Member, and the basal beds of the Blockhouse Shale (Whitesburg Limestone Member and unnamed sandstone member) are preserved. The boundary of the core thus appears to be a normal stratigraphic succession in some places but a fault in others, and on plate 2 and figure 10 it is shown with special symbols.

Figure 12 illustrates the relations of this contact southwest of High Top. Here the Jonesboro is folded and cut by faults like those at Cedar Bluff (fig. 11), but synclines preserve the Mosheim Member of the Lenoir Limestone and the basal part of the Blockhouse Shale. Above an undulating fault, a thin ledge of sandstone overlies the Jonesboro and younger formations. For about 100 feet the sandstone is duplicated by faulting; but toward the ends of the exposure the sandstone above the fault thins and disappears, and shales of the main body of the Blockhouse overlie the Jonesboro.

More complex relations at the top of the limestone core were mapped at 1:1,200 scale near Walker Hollow in the northern part of Tuckaleechee Cove in the Wear Cove quadrangle (pl. 5). There the boundary between the limestone core and the shale mantle is exposed on five ridges. Each ridge displays different relations; the shale mantle in all five, however, is faulted over the limestone core, and the core is cut by gently dipping faults. The contact at the top of the limestone strikes northeastward on each ridge; cross structures displace it southward in each of the intervening valleys, however, so that the gross trend is eastward across the area. The cross structures may be left-lateral strikeslip faults, normal dip-slip faults downthrown to the northwest, or shallow flexures; the last is preferred because such a flexure was mapped in the central part of the area.

Still more intricate structures in which low-angle faults interleave slices of limestone with shale are visible near Tuckaleechee Caverns and Dunn Spring (pl. 3 ; fig. 10). There the Blockhouse Shale in the lowest structural block (pl. 3, section $S-S^{\prime}$ ) is overlain by a thrust slice of Jonesboro Limestone, and this, in turn, is overridden by a second limestone slice containing Blockhouse Shale at the top, succeeded by another limestone slice, and the whole area is capped by rocks of the Ocoee Series of the Great Smoky thrust sheet.

The Blockhouse Shale through most of Tuckaleechee Cove is crumpled. Tight folds with amplitudes of a few inches are characteristic of most outcrops, as are slickensided and polished surfaces that in some places cut across bedding and in others are parallel to it. Slaty cleavage, such as that of the fine-grained rocks of the Ocoee Series nearby, is lacking in the Blockhouse, and these rocks are not recrystallized or metamorphosed.

Limestone slices lie just beneath the Great Smoky fault around much of Tuckaleechee Cove. In most places the rocks in these slices are so fractured and deformed that bedding and other sedimentary features are obscured, but nowhere has the rock been recrystallized to marble. Most of these limestones cannot be placed in the subdivisions of the Knox Group. At the eastern end of Tuckaleechee Cove, however, the limestone of one slice is overlain by the Blockhouse Shale, so that it must be near the top of the Knox. Near Red Bank in the southeastern part of the cove, fossils indicate that the limestones are at least partly of Longview age, the same as those of Cades Cove to the southeast; this slice, which is as much as 700 feet thick, may continue for more than 2 miles north of Red Bank and southeastward into Whiteoak Sink. In Whiteoak Sink and the caves beneath, strongly overturned folds are indicated by variations in dip from nearly vertical to horizontal.

In Wear Cove to the east (King, 1964) there is also a well-defined limestone core with an apparently unbroken stratigraphic succession into the shale mantle, overlain by limestone slices like those in Tuckaleechee Cove. 


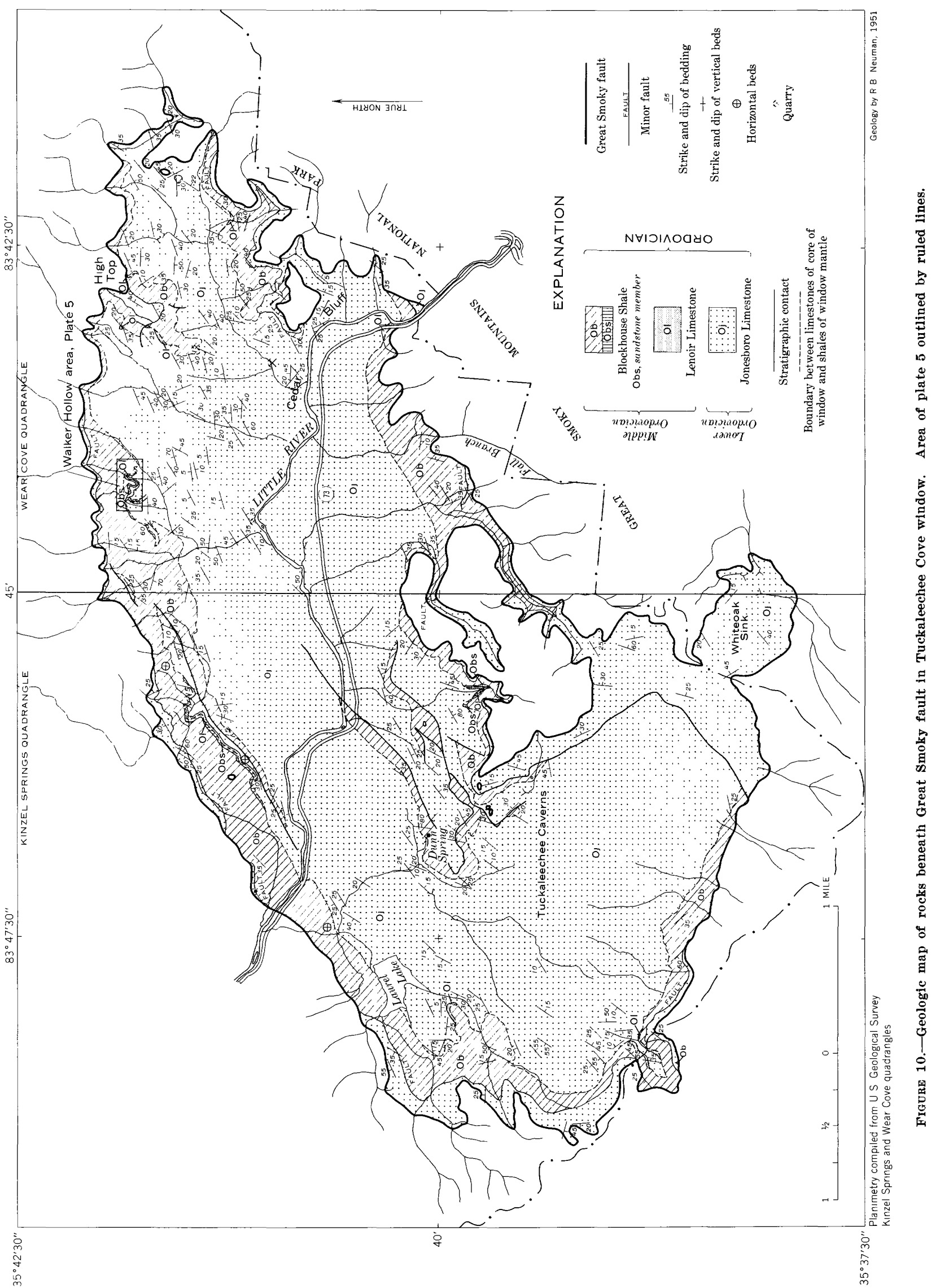




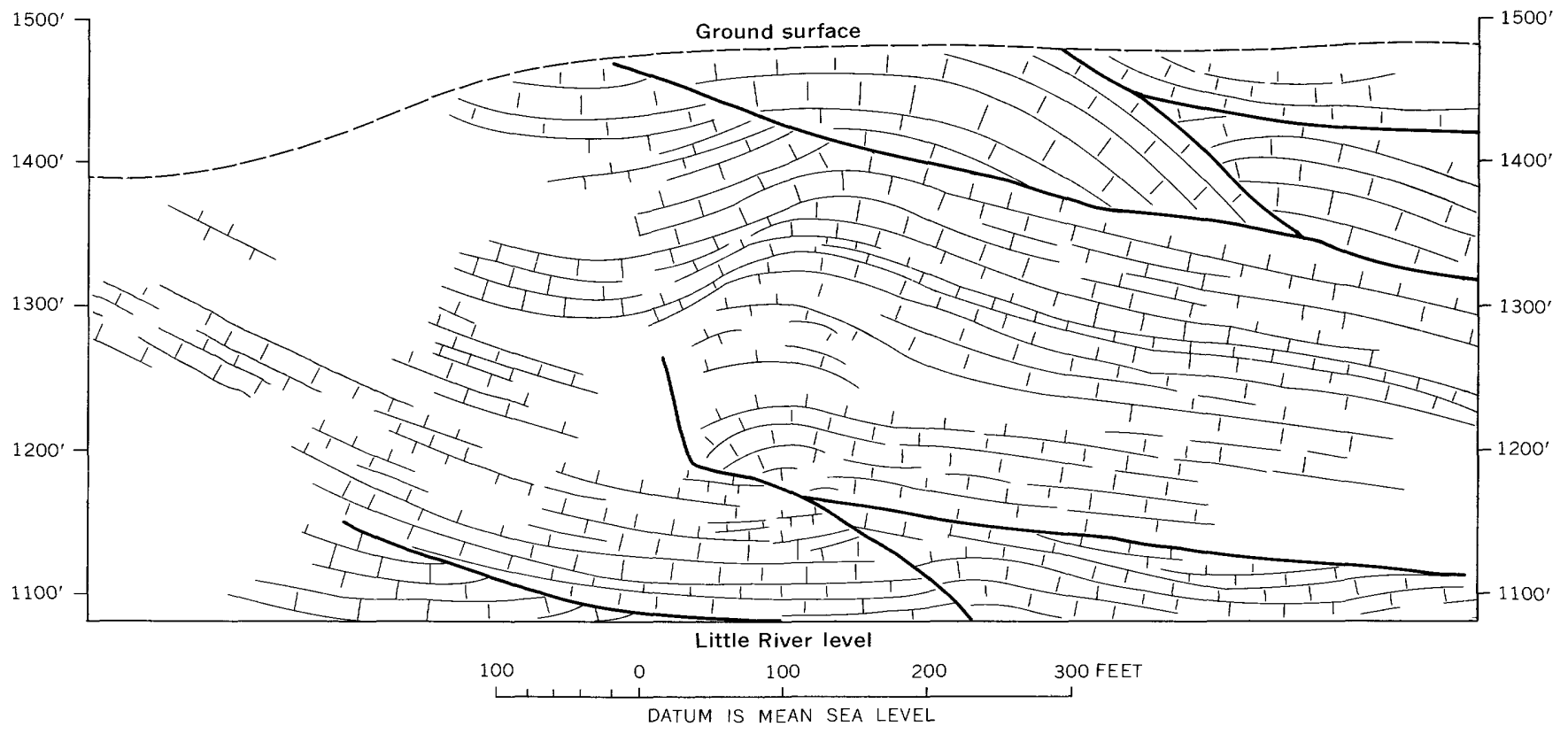

Frgure 11.-Geologic sketch of Cedar Bluff, Tuckaleechee Cove, showing bedding and faults in the Jonesboro Limestone.

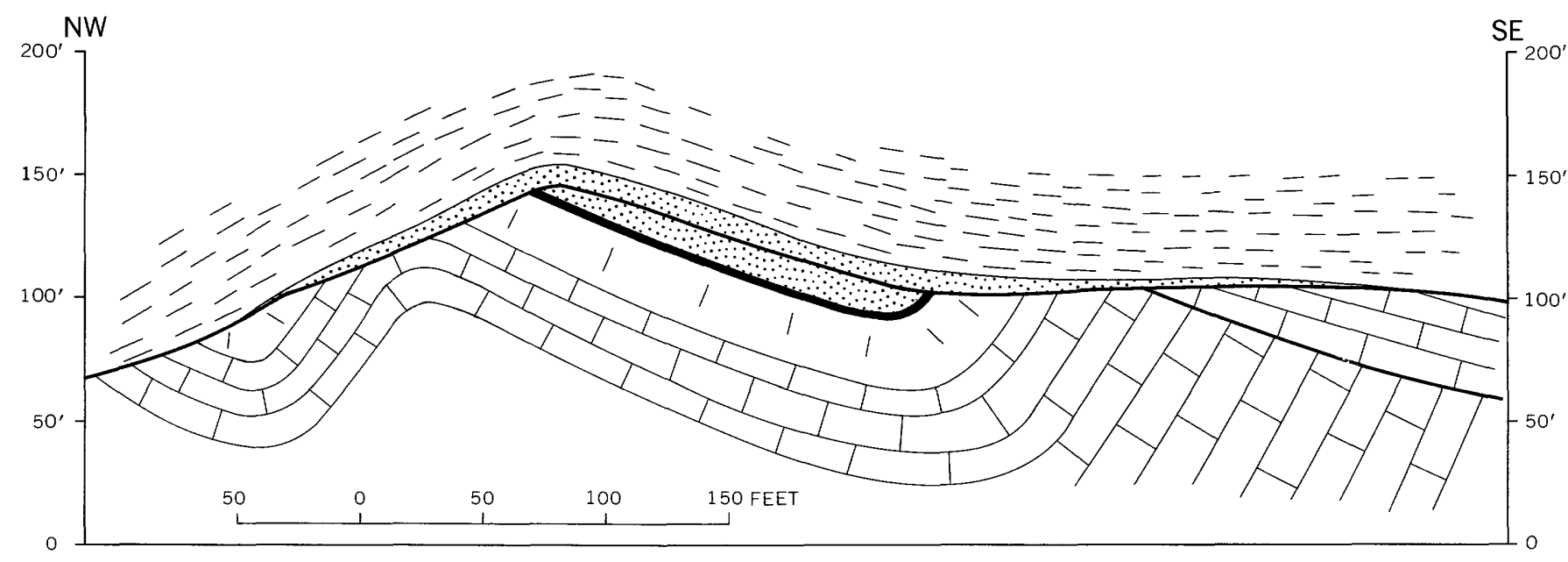

EXPLANATION

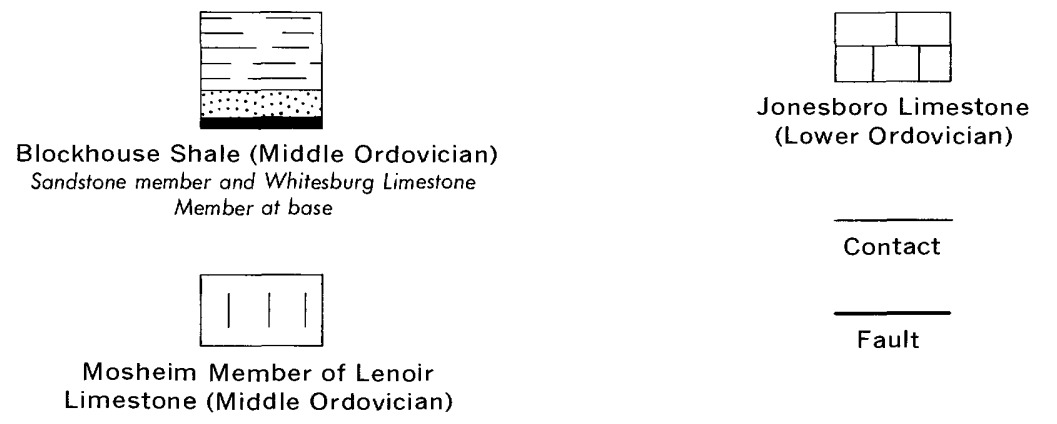

Figure 12.-Geologic section of High Top, Tuckaleechee Cove. 
The limestones in the Cades Cove and Calderwood windows are somewhat older than those of Tuckaleechee and Wear Coves, but they do not possess key beds that permit mapping structural details. In both areas some beds have gentle to moderate dips, but the structure appears to be complex as indicated by steep dips elsewhere. Because neither Chepultepec nor Mascot equivalents were identified in these windows, the total thickness of the beds exposed in them is probably no more than 1,500 feet, so that the complex structures may be local crenulations.

\section{GREAT SMOKY FAULT}

The great low-angle fault that separates Early Cambrian and older rocks from the younger rocks in this area was not recognized by the early geologists. Safford $(1869$, p. 190) and Keith (1895) saw that the rocks of Chilhowee Mountain were thrust over younger rocks toward the northwest. Stafford (1869, p. 219) explained the presence of limestones in the windows as having been "entangled" with the older rocks during the faulting and folding, and Keith showed them in the cores of anticlines, overlain stratigraphically by "mountain rocks." The magnitude of the faulting was first recognized by Gordon in 1920; later, Keith (1927) corrected his early views and named the Great Smoky fault.

The Great Smoky fault is an undulating surface (pl. 6) along which the Chilhowee Group and Ocoee Series were thrust over Lower and Middle Ordovician rocks. The fault emerges along the entire northwest face of Chilhowee Mountain and reappears in windows to the southeast. Along Chilhowee Mountain the overridden rocks are Middle Ordovician shales in most places, but in a few places thin slices of Jonesboro Limestone no more than half a mile long intervene. The rocks on the hanging wall are shales, quartzites, and conglomerates of the Chilhowee Group and the Sandsuck Formation. The fault surface is probably not exposed anywhere along Chilhowee Mountain in the report area, but in many places it can be located closely by nearly adjacent outcrops of the contrasting rocks. The dip of the fault, determined in several places by its trace on the topography, is $30^{\circ}-40^{\circ} \mathrm{SE}$. The fault is not parallel to the contorted bedding of the overridden rocks; it is nearly parallel to the overriding rocks, although in places it cuts the rocks of the Chilhowee Group at a low angle.

The surface of the Great Smoky fault is exposed at several places around the margins of the Tuckaleechee Cove window. On the road between Wear Cove and Tuckaleechee Cove, 0.65 mile southwest of the boundary line between Blount County and Sevier County
(King, 1964), the fault dips about $20^{\circ}$ south, but its mapped trace indicates that it is nearly horizontal. The overridden rocks are part of the limestone core of the window and are fractured and veined Jonesboro Limestone. The overriding rocks are intensely sheared phyllitic shale and sandstone of the Licklog Formation (King, 1964, fig. 15C; p. 94). Between them, along the fault, is a gouge of pulverized rock about 6 inches thick. The fault is also exposed at two waterfalls, one in Fall Branch and one at the eastern edge of Whiteoak Sink (both in the Wear Cove quadrangle, King, 1964). At Fall Branch the footwall rocks are fractured Jonesboro Limestone in a small tectonic slice, and at Whiteoak Sink they are part of a larger slice of Jonesboro Limestone. At both waterfalls the overriding rock is intricately deformed Metcalf Phyllite, and the fault surface is smooth, nearly flat, and without gouge. In the exposure along Tennessee Highway 73 just northwest of the Park boundary (King, 1964, pl. 11; Hadley and others, 1955, p. 424; Neuman, 1951, p. 749) a thin slice of Jonesboro Limestone can be seen between the Metcalf and the Blockhouse, as can the dislocation between the Blockhouse and the limestone core.

Elsewhere around Tuckaleechee Cove the trace of the Great Smoky fault can be located accurately at many places. In some places its dip can be observed, and in others it can be computed from its relations to topography. Everywhere its dips are gentle or nearly flat. The highest altitude at which the fault is exposed is at 2,300 feet on the west side of Whiteoak Sink (pl. 3). From here the fault dips gently northeastward toward a structural terrace and dome along the axis of the window, but it resumes its gentle northward dips along the northern margin of the window.

In Cades Cove (fig. 13) the fault can be mapped accurately for about a mile on the north side, where it dips gently northward, and at two places on the south side, where it dips gently southward. At other places, its position cannot be located accurately, but sinkholes at opposite ends of the cove indicate the presence of limestone of the overridden block, with rocks of the overriding block nearby. Around Cades Cove, the trace of the Great Smoky fault emerges at 1,700-2,000 feet above sea level.

In the Calderwood window the highest altitude reached by the Great Smoky fault is about 1,200 feet, at an exposure on the north side of U.S. Highway 129, about 200 feet east of the junction of the road to Calderwood village (fig. 14A). There the overridden rocks are Jonesboro Limestone whose bedding structures are well preserved, and the overriding rock is weathered silty phyllite of the Wilhite Formation whose bedding was obliterated by shearing. The fault 


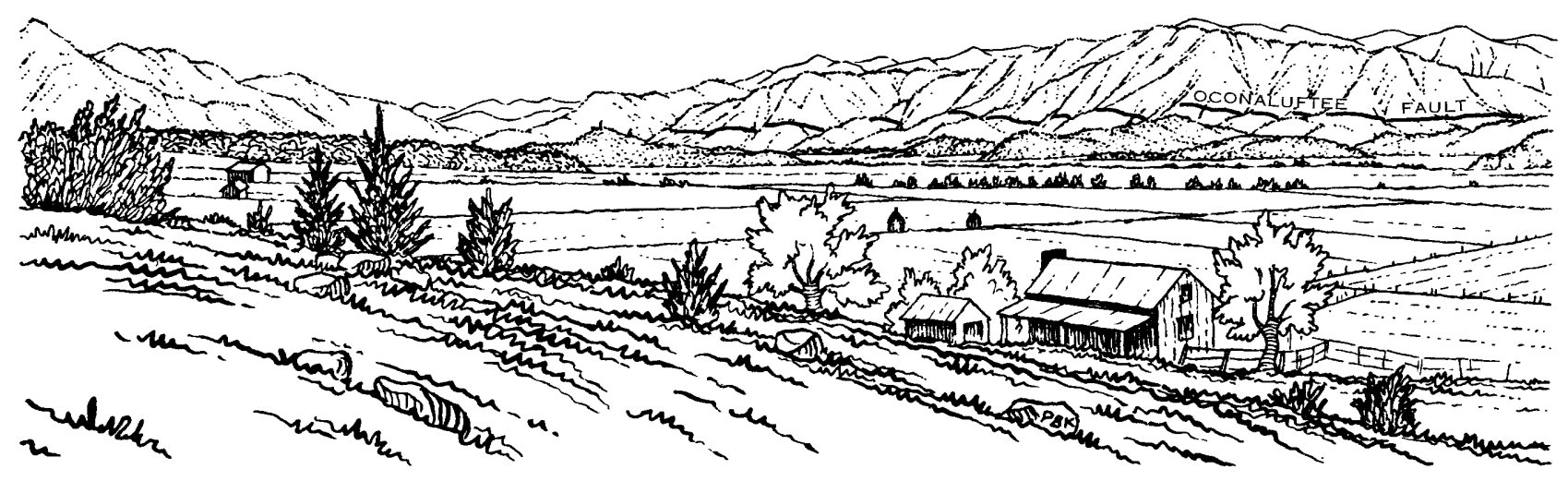

Figurn 13.-View of Cades Cove, looking east-southeast. The trace of the Great Smoky fault lies between the viewer and the house (now dismantled) in the foreground, and elsewhere largely rims the cove floor. The trace of the Oconaluftee fault lies approximately at the break in slope between the spurs and the main ascent of the mountains that form the backdrop of the cove in the central and right:hand parts of the view. Drawing by Philip B. King.

$\operatorname{dips} 20^{\circ} \mathrm{E}$. on the east side of the exposure and $30^{\circ} \mathrm{W}$. on the west side. The window extends westward across the river, where about 400 feet of Jonesboro Limestone crops out in bluffs. The limestone is overridden on the southeast by sheared phyllite along a contact that dips about $30^{\circ} \mathrm{SE}$; to the north, however, the limestone overlies conglomerate of the Wilhite Formation along a contact that dips about $60^{\circ} \mathrm{SE}$. This is the only place in any of the windows where the Great Smoky fault dips steeply toward a window. The limestone on the west side of the river may be an incipient tectonic slice like those which have been torn away from the overridden block and now lie beneath the fault.

The rocks above the Great Smoky fault around the windows belong to the Chilhowee, Walden Creek, and Snowbird Groups. Two tectonic slices in the southwestern part of the Wear Cove window are formed of the Chilhowee Group (Wear Cove and Gatlinburg quadrangles, King, 1964), and a small patch of white quartzite of the Chilhowee Group with Scolithus caps a hill in the northwestern part of Tuckaleechee Cove (pl. 3). The Line Springs fault, part of the major fault system which separates the Walden Creek Group from the Snowbird Group for many miles in the foothills to the northeast, is cut off at a small angle by the Great Smoky fault near the eastern end of Tuckaleechee Cove (Wear Cove quadrangle, King, 1964). The continuation of this fault west of the window may be the low-angle Rabbit Creek fault which separates the Cades Sandstone from the Wilhite Formation, and which also makes an acute angle with the Great Smoky fault.

Minimum displacement of the Great Smoky fault is about 10 miles, reckoned from the distance of 8.5 miles between the south side of Cades Cove and the northwest side of Chilhowee Mountain and from the 1.5-mile width of the Chilhowee Mountain block. The Chilhowee Mountain width is added because metamorphic minerals which formed before thrusting are now telescoped against nonmetamorphosed rocks around the windows; the elided transition zone is estimated to have been at least as wide as the distance between the Miller Cove fault and the Great Smoky fault to the northwest.

Maximum displacement is unknown and cannot be determined by matching overriding rocks with those of the overridden block.

Structure contours drawn on the Great Smoky fault are shown on plate 6 , and the fault is shown in the structure section of plates 2 and 4 . The contour map was constructed from the known altitudes of the trace of the fault, and the configuration of the fault in the structure sections is based on these contours. The contours are well controlled only near the trace, and in most of the area they are extrapolated from the known dips. Such extrapolation between the windows and Chilhowee Mountain indicates that little of the Great Smoky fault extends deeper than 1,000 feet below sea level, so that structural relief there is about 3,500 feet. Information is inadequate for the construction of contours southeast of the windows, but the gentle dips of the fault at the southeast edges of the windows suggest that it dips gently beneath the main range of the Great Smoky Mountains.

East of the present area in Wear Cove and in the Fair Garden anticline (King, 1964; Hamilton, 1961) the Great Smoky fault is broadly concordant to the structure of the Knox Group. The anticlinal core of the Wear Cove window is not disrupted as it is in Tuckaleechee Cove, and the Jonesboro dips away from the center more steeply than the surrounding Great Smoky fault. On the southeast flank of the Fair Garden anticline the top of the Jonesboro Limestone also 
dips more steeply than the Great Smoky fault a short distance to the southeast (King, 1964). At one place, near Grannys Knob, where the fault approaches the limestones, they are folded and faulted as they are in Tuckaleechee Cove (Hamilton, 1961; Neuman, 1951, p. 745).

The overridden rocks consist of two structural elements-the deep syncline on the northwest and a struc-

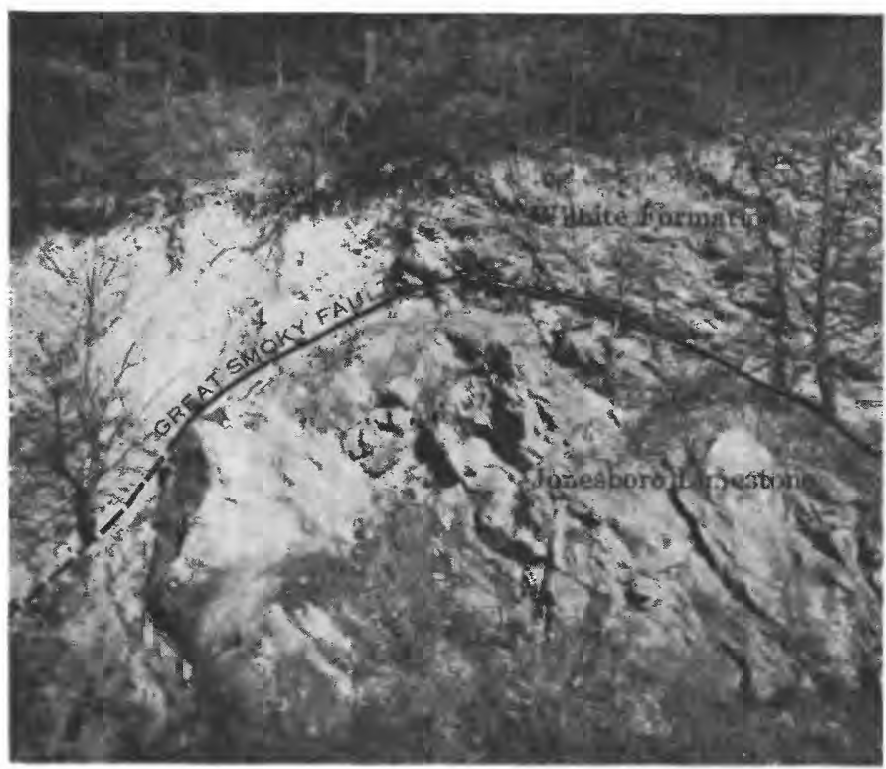

A. Great Smoky fault at the Calderwood window. U.S. Highway $129,0.5$ mile northeast of Calderwood.

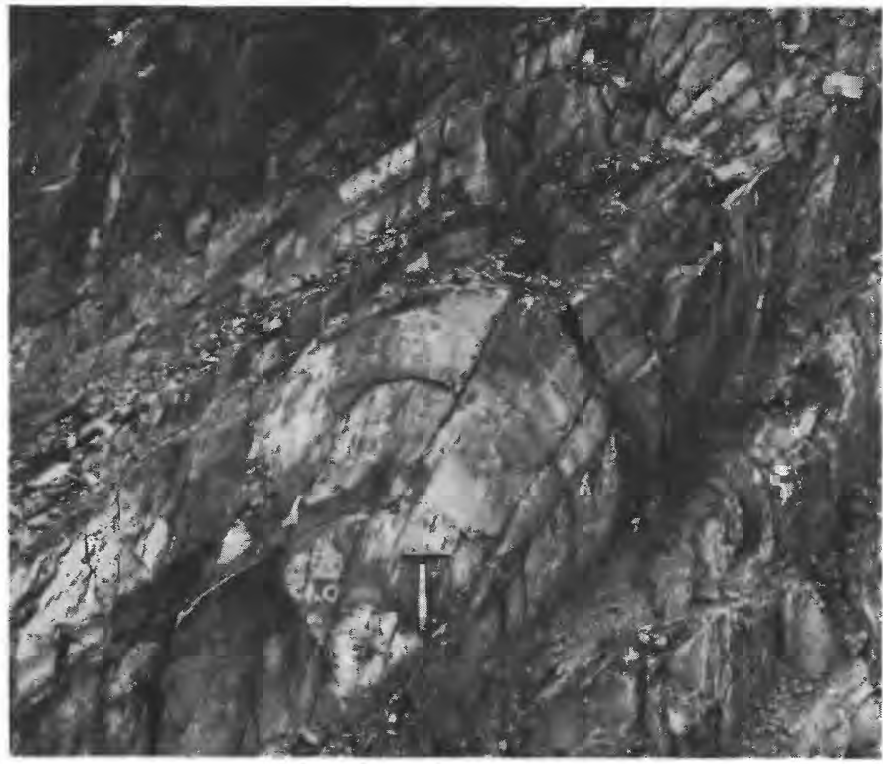

C. Asymmetrical fold with fanning slaty cleavage. Wilhite Formation, 0.4 mile northwest of Davis Branch, Tennessee Highway 73. Photograph by Warren Hamilton. tural terrace that includes the windows and extends southeastward beyond them, juxtaposed along the Guess Creek fault. The Great Smoky fault seems to have cut across progressively younger beds as it moved northwestward across the terrace, finally reaching the incompetent Middle Ordovician shales which served as a ready lubricant. Around Wear Cove the fault rode high in the lubricating shale, and the limestone was

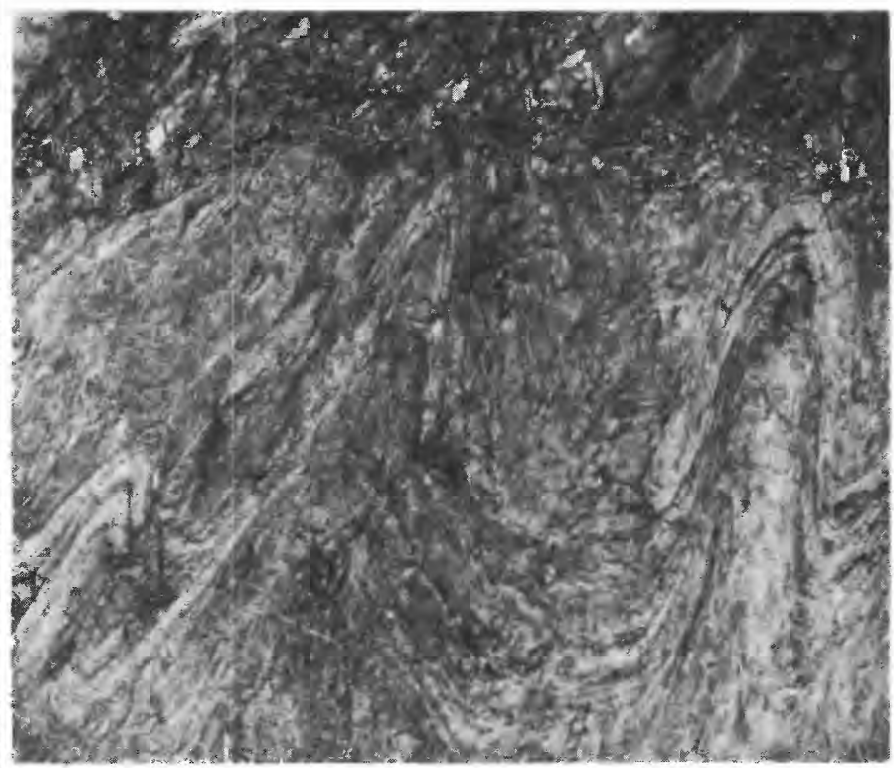

B. Asymmetrical attenuated folds in the Wilhite Formation, 0.2 mile northwest of Davis Branch, Tennessee Highway 73. Picture includes area about 35 feet high and 50 feet wide; compare with figure 16. Photograph by Warren Hamilton.

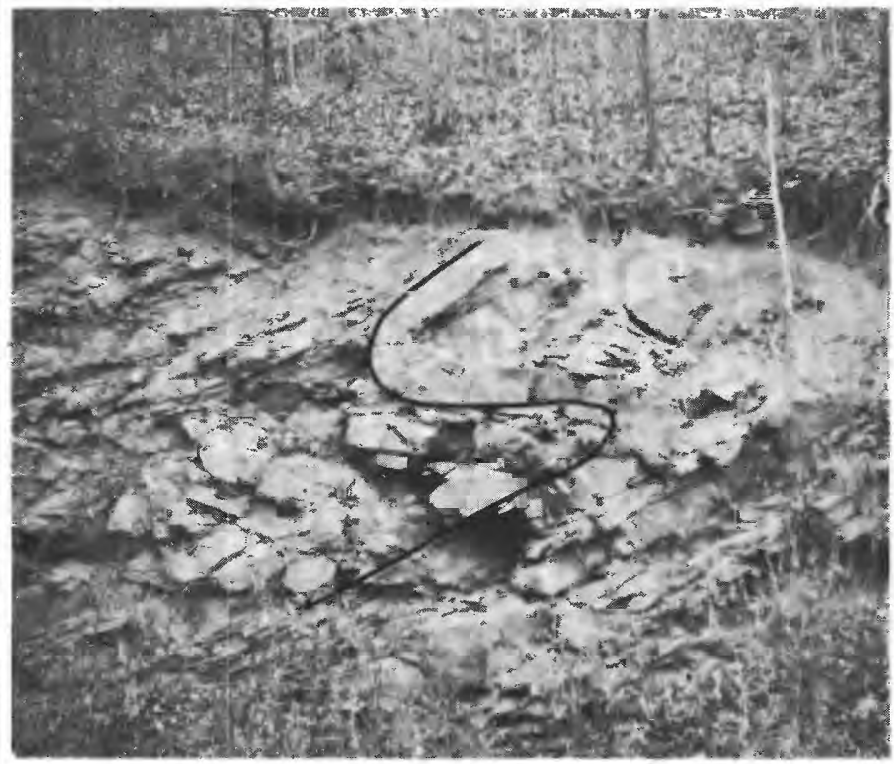

D. Recumbent folds. Wilhite Formation, 1.3 miles north of Calderwood, U.S. Highway 129. Graded bedding in sandstone indicates tops of beds face northwest, toward the right of the picture. 
protected from disruption in most places. In Tuckaleechee Cove the Great Smoky fault dragged a mass of the lubricant over the limestone core and in places broke through and disrupted it, picking up the fragments of Jonesboro Limestone which are now exposed along Chilhowee Mountain.

The traces of the Guess Creek fault and related structures and of the Great Smoky fault through the map area and beyond suggest that they are closely related in origin, but these relations can be interpreted in at least two ways. In one (fig. $15 A$ ), the Guess Creek fault would be a subsidiary and nearly parallel branch of the Great Smoky fault, formed between strata of contrasting competence within the overridden rocks beneath the thrust sheet. An unnamed fault mapped within Mississippian rocks would mark the base of this disturbed zone, with minimum tectonic transport, and each successive block from north to south would have been transported a greater distance, reaching a maximum at the Great Smoky fault itself.

Alternatively (fig. $15 \mathrm{~B}$ ), the Guess Creek fault is not parallel to the Great Smoky fault down dip. It is a reverse fault of moderate southeast dip, which crosses the Paleozoic sequence to an unknown depth with a displacement of about 2,000 feet; the unnamed fault within Mississippian rocks to the northwest would be a branch with less displacement. By this interpretation the Great Smoky fault followed Middle Ordovician shale over the Tuckaleechee Cove uplift, probably incorporating some of it into the moving mass. The Great Smoky fault would then cross upturned beds on the southeastern limb of the syncline, but would remain in the block uplifted by the Guess Creek fault. The Guess Creek fault would then be earlier than the Great Smoky overthrust, and later would have controlled its emplacement.

Interpretation A has the virtue of simplicity, for it makes the Guess Creek fault part of the Great Smoky fault system, and it formed at the same time. The narrow belt of Middle Ordovician rocks that lies between the faults on Chilhowee Mountain would be a carpet of incompetent slightly transported material over which the farther traveled overlying Great Smoky thrust advanced.

Interpretation B is preferred, however, because east of the report area and east of Chilhowee Mountain the traces of the Great Smoky and Guess Creek faults diverge widely, as though they were unrelated features. Moreover, on Chilhowee Mountain itself, where the two faults are close together and parallel, the continuity of the narrow band of incompetent rocks between them is greater than one would anticipate if it were merely a carpet beneath the Great Smoky fault. Also, the rocks of this narrow band, wherever they can be identified,
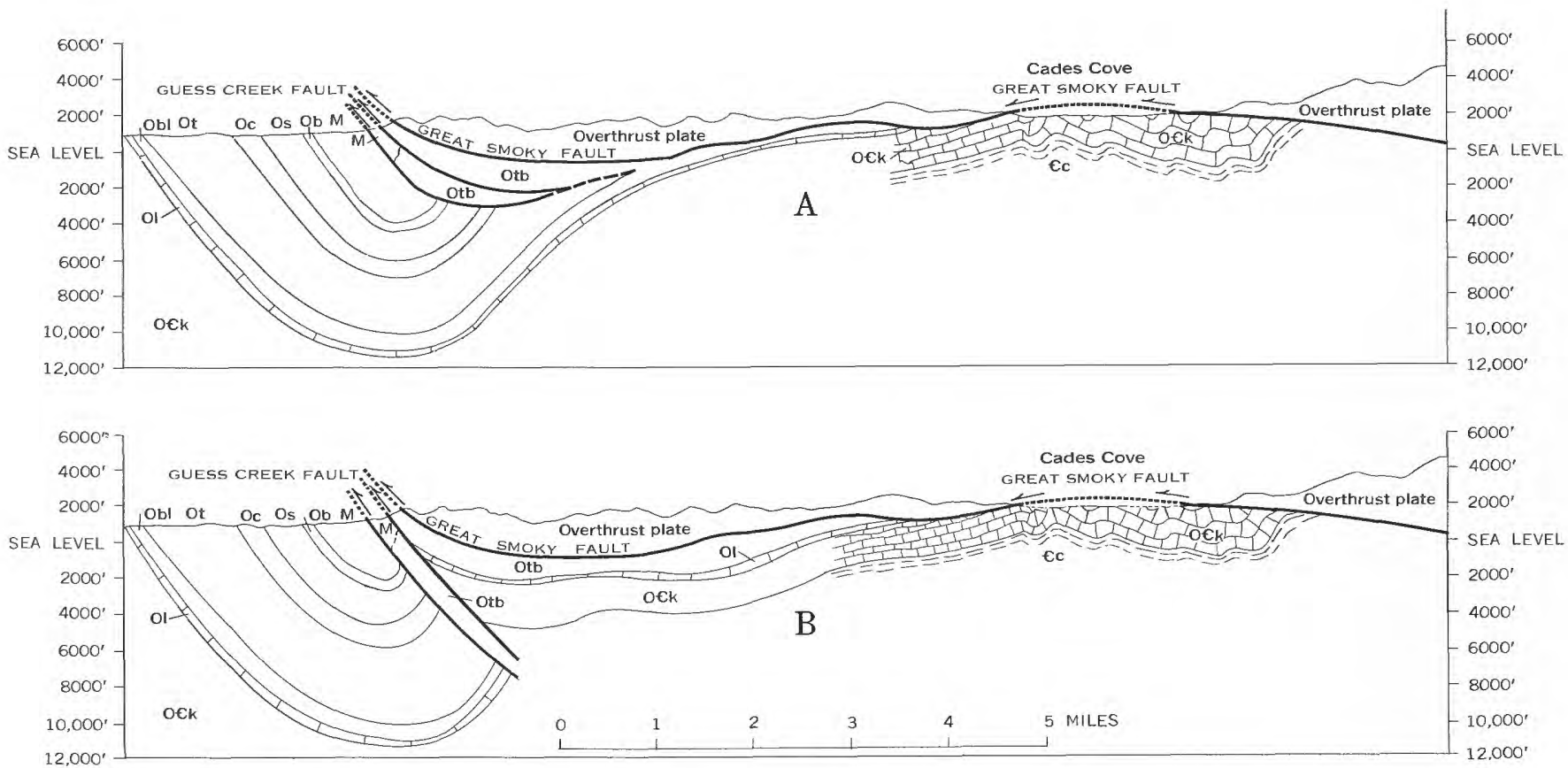

FigUre 15.-Geologic sections showing alternative projections of rocks overridden by the Great Smoky fault, based on section $D-D^{\prime}$ of plate 2. M-Mississippian rocks, Ob-Bays Formation, Os-Sevier Fórmation, Oc-Chota Formation, Ot-Tellico Formation, OblBlockhouse Shale, Otb-Tellico and Blockhouse Formations, undifferentiated, Ol-Lenoir Limestone, O€k-Knox Group, €c-Conasauga Group. 
are all of the lower part of the Middle Ordovician sequence, and no higher rocks have been identified.

The undulations of the Great Smoky fault may be explained by folding of a flat overthrust (Keith, 1928, p. 330), by simultaneous thrusting and warping, or by faulting along an irregular surface. Dips of the fault here, and of the rocks both above and below it, are relatively gentle compared to the steep dips around some windows in Nevada where folding and faulting were concurrent (Gilluly, 1960, p. 73). The mapped patterns of the two areas differ considerably. Faults that branch from the thrust surface as they do in the Hot Springs window, North Carolina (Oriel, 1950), were interpreted by Gilluly $(1960$, p. 76$)$ to indicate folding contemporaneous with thrusting. The Line Springs fault in Wear and Tuckaleechee Coves (King, 1964) looks like one of the branch faults in the Hot Springs area, but the Dunn Creek fault system to which it belongs is premetamorphic (Hamilton, 1961, p. 40) and earlier than the Great Smoky fault. Movement may have been renewed along the Line Springs fault near the windows, but its intersection with the thrust surface there appears to be fortuitous and probably does not indicate that folding was contemporaneous with faulting. That some folding of the lower plate preceded faulting and influenced the configuration of the fault surface is indicated by the quaquaversal dips of the anticlinal limestone cores in the Tuckaleechee and Wear Cove windows, which are steeper than the fault surface above, and by some fold crests which appear to have been planed off by the fault.

\section{CHILHOWEE MOUNTAIN STRUCTURAL BLOCK}

The rocks of Chilhowee Mountain are a structural block bounded by the Great Smoky fault on the northwest and by the Miller Cove fault on the southeast. The block consists of two segments, a syncline northeast of Look Rock and a southeast-dipping homocline to the southwest. Both segments contain minor folds and faults which are well shown in many places by the thin easily mapped formations of the Chilhowee Group.

At the northeast edge of the map area (pls. 2,3), the syncline plunges about $10^{\circ}$ southwest for about 1 mile and preserves a sequence from the Helenmode to the Rome. Its axis then flattens and is nearly horizontal for about 5 miles along Miller Cove. Within this segment is a small northeast-trending reverse fault and a transverse fault with a right-lateral strike-slip displacement. A small area of the Rome Formation at the high school at Walland (pl. 3) occurs along this transverse fault and suggests the complexities of its displacement. Toward the northwest this fault transects the Chilhowee Group and is followed by the Little River. This fault lies within outcrops on the northeast side of the river, bringing formations together so as to produce anomalies which have been misinterpreted in the past (Keith, 1895; Stose and Stose, 1949, p. 299). Swingle's mapping indicates that the Helenmode Formation here is faulted against the Nebo Quartzite, and that the Murray Shale and Hesse Quartzite are not exposed at road level. In these exposures, numerous east-west-trending vertical fractures in quartzite with nearly horizontal slickensides indicate strike-slip displacement. Traced westward the fault displaces lower formations of the Chilhowee Group in the same sense; it does not cross the Great Smoky fault because neither that fault nor the overridden rocks show similar offset.

Another cross fault may occur at the southwest end of Miller Cove where the Rome Formation is terminated abruptly and the Helenmode Formation on the hillside to the north is displaced. Outcrops of the Rome abut against a knoll (on which is a small hotel known as Blackberry Farm) that has outcrops of Shady Dolomite at its base and many large blocks of jasperoid on its crest. The Helenmode Formation similarly abuts against a spur of Chilhowee Mountain on which there are numerous outcrops of Hesse Quartzite, but at the crest of the mountain the contact of the Hesse with the underlying Murray Shale is undisturbed. This transverse fault must be nearly vertical and seems to be hinged, with displacement increasing southward from zero at the crest of the mountain to at least 500 feet next to the outcrop of the Rome Formation.

Southwest of the cross fault, four isolated areas on southeastern spurs of Chilhowee Mountain are capped by jasperoid and are interpreted as outliers of the Helenmode Formation and Shady Dolomite. Alluvium covers much of the flat to the south, but outcrops of dolomite along Hesse Creek and sinkholes near summer cabins at the southwestern end of the flat (see Blockhouse quadrangle, Neuman and Wilson, 1960) indicate the presence of the Shady beneath. On hills to the west, above the lowlands, are glauconitic sandstone of the Helenmode Formation and ledges of the Hesse Quartzite, both dipping eastward beneath the Shady. Hesse Creek enters the flat through a steep-sided gorge in quartzite and shale which are probably a complex of fault slices, at least one of which includes the Cochran Formation.

The broad plateau of The Flats is formed by Hesse Quartzite, warped into a shallow syncline in whose trough a small outlier of weathered Helenmode and Shady is preserved. The southern margin of the syncline is broken by a reverse fault which brings the Nebo Quartzite against the Hesse. Thickness differences of the formations of the Chilhowee Group on 
opposite flanks of the syncline are probably due to concealed minor structures.

In the vicinity of Look Rock a hinged fault displaced in the opposite sense from that in the southwestern part of Miller Cove places the Hesse Quartzite on the west against the Nebo. East of this fault and south of Murray Gap, the Nebo emerges from beneath the Murray in a small anticline as well as in a larger area on the lower slope of the mountain. Above the Murray at the southwestern end of The Flats syncline are prominent cliffs of Hesse Quartzite. West of the cross fault at Murray Gap, the Hesse dips uniformly southeastward, although it is here thicker than elsewhere and is probably repeated by faults, one of which also repeats the Murray Shale near Chilogatee Gap. Farther southwest, another fault brings the Cochran against the Murray, Nebo, and Nichols, and near Tallassee against the Cochran of the main part of Chilhowee Mountain. At the Little Tennessee River the base of the Cochran forms an open syncline that plunges gently northeast. Southwest of the Little Tennessee River, beyond the report area, the Chilhowee Mountain block may consist entirely of Sandsuck Formation, difficult to distinguish from the conglomeratic rocks of the Wilhite Formation to the southeast.

The rocks of the Chilhowee Mountain block are little altered compared with those to the southeast in the upper plate of the Great Smoky fault. Slaty or fracture cleavage in the more argillaceous rocks is present only in the few places where beds dip northwest or are nearly flat. Where present, cleavage dips $50^{\circ}-65^{\circ} \mathrm{SE}$., and cleavage surfaces are widely spaced and lack micaceous lustre. Similarly, the grains in quartzites of this block are not tectonically distorted as they are in sandstones farther southeast.

\section{MILLER COVE FAULT}

The southeastern boundary of the Chilhowee Mountain block is the Miller Cove fault, along which the Wilhite Formation is thrust over the Sandsuck Formation, the Chilhowee Group, Shady Dolomite, and the Rome Formation. This fault was mapped by Keith $(1895,1896 \mathrm{a})$ in much the same position as shown in the present report. In most places the fault juxtaposes markedly different rocks, so that it can be mapped with reasonable accuracy even in areas of deep weathering.

The Miller Cove fault extends from a junction with the Great Smoky fault at the Little Pigeon River, 10 miles northeast of the edge of the report area (King, 1964), southwestward to the Little Tennessee River. It enters the Kinzel Springs quadrangle (pl. 3) from the northeast, with Sandsuck on the footwall and siltstone of the Wilhite Formation on the hanging wall. To the southwest along Reed Creek its trace is mostly concealed beneath alluvium; but near the Little River it crosses the lower slopes of Miller Cove Mountain, and the Shady Dolomite forms its footwall. The fault is crossed by old Tennessee Highway 73 in a low saddle between Dick Creek and the Little River, where outcrops of Shady are separated from those of Wilhite by the width of the road. The new highway on the west side of the Little River crosses the fault where it is concealed beneath the broad flood plain at the mouth of Hesse Creek. Farther southwest, at several places along Hesse Creek, the Wilhite of the hanging wall contains limestone that resembles the overturned Shady Dolomite of the footwall. Near the mouth of Wolf Creek, maroon siltstone of the Wilhite Formation lie adjacent to similar rocks of the Rome Formation. At the southwest end of Miller Cove, the Chilhowee Mountain block is cut into several slices that bring quartzite of the Chilhowee Group against the fault, and the contrast between these slices and the Wilhite siltstones is more pronounced. The fault departs from its northeast-southwest trend and from the topographic grain near the headwaters of Chilhowee Creek, south of Look Rock, and trends west to the base of Chilhowee Mountain adjacent to the area where the Chilhowee Mountain block changes from a syncline to a homocline. Beyond, the Miller Cove fault lies at a sharp break in slope between the southeast flank of Chilhowee Mountain and Happy Valley; it can be identified by the abrupt contrast between the clean well-sorted quartzites of the Hesse and the more argillaceous heterogeneous rocks of the Wilhite Formation. Structural discordance is abrupt, as the overriding rocks dip steeply northwest, whereas those of the Chilhowee Mountain dip moderately southeast.

The surface of the Miller Cove fault was observed at only one point, on slopes east of Dick Creek (pl. 3), where it dips $30^{\circ} \mathrm{SE}$. In most places its trace on the topography indicates that it dips between $30^{\circ}$ and $45^{\circ}$ S. and SE., but locally it has both steeper and more gentle dips. Shallow saddles and ravines along its trace show that the rocks near the fault are more easily eroded and are thus more broken than those at greater distance from it, but no shattered rocks or shear zones were observed.

The Miller Cove fault was interpreted (Neuman, 1951, p. 747) to be a relatively minor branch of the Great Smoky fault, but metamorphic and structural discontinuities since observed show that it is a fault of first-rank importance. The metamorphic discontinuities indicate that it is younger than the premetamor- 
phic faults, such as the Dunn Creek and Greenbrier (Hamilton, 1961, p. 40; Hadley and Goldsmith, 1963, p. B78-B79), and it is presumably more closely contemporaneous with the Great Smoky fault. Hamilton (1961) labeled a similar fault farther east in the Richardson Cove and Jones Cove quadrangles the Great Smoky fault and suggested that displacement along it was greater than along the English Mountain fault at the base of the Chilhowee Group farther north. It seems likely that the Miller Cove is related to the Great Smoky fault, and that the Chilhowee Mountain block is a part of the Great Smoky thrust sheet that was picked up late in its development and carried ahead of the main part of the overthrust sheet.

\section{ROCKS BETWEEN MILLER COVE AND RABBIT CREEK FAULTS}

The fault block just southeast of the Miller Cove fault contains complexly folded and faulted rocks of the Walden Creek Group. Through most of the report area (pl. 2) the Rabbit Creek fault forms the southeast margin of this fault block, except near Tuckaleechee Cove where the Rabbit Creek fault merges with the Great Smoky fault. The block itself is broken by the large Capshaw Branch and Happy Hollow faults and by smaller high-angle reverse faults.

The belt northwest of the Capshaw Branch fault is crossed diagonally by a large anticline whose axis lies about midway between the Little Tennessee and Little Rivers. Its northwestern limb contains the thick northwest-facing sequence along the Little Tennessee River; its southeastern limb contains the southeastward-facing sequence along the Little River, beyond which is the Bates Mountain synclinorium.

The Bates Mountain synclinorium in the northeastern part of the Kinzel Springs quadrangle (pl. 3) is the eastern half of an irregular but shallow syncline which, in the present area, plunges gently east, and, to the east in the Wear Cove quadrangle (King, 1964), plunges gently in the opposite direction, so that a closed basin is defined. The synclinal axis strikes nearly east-west, and projects westward toward the
Miller Cove fault. Westward, however, the syncline is lost in thin-bedded siltstone which has, minor folds whose axes trend from N. $45^{\circ}-\mathrm{N} .60^{\circ} \mathrm{E}$. and for the most part plunge gently northeastward.

The small-scale folding of the siltstones is well shown in highway cuts on both sides of the Little River. On the southeast (figs. $14 B, C ; 16$ ) gray "iron banded" siltstone on the east side of the river is contorted into shear folds cut by reverse faults parallel to slaty cleavage. Farther northwest, similar structures deform maroon, green, and gray siltstone. $\mathrm{Nu}$ merous reversals of dip and the absence of key stratigraphic units prevent determination of major structure, but the appearance of sandstones, including the unusual maroon beds, that dip beneath the siltstone at the northwest edge of the belt and the dominance of southeast dips in the siltstone suggest that the overall dip is gently southeastward.

Farther southwest, intricate folding of the Wilhite is shown by the varied strikes and dips observed. Southwest of Hurricane Branch the outcrop belt of the Wilhite siltstones is narrowed to as little as 900 feet by encroachment of the Capshaw Branch fault. Here, southeast dips prevail as far as the anticlinal axis northwest of Cane Gap. This anticlinal axis lies athwart the outcrop belt at an oblique angle, cut off by the Miller Cove fault at the east and by the Capshaw Branch fault about 1.5 miles to the southwest. At its core are exposures of medium- to coarse-grained feldspathic sandstone and conglomerate like the lower beds of the Wilhite along the Little River, but without red beds. West of this anticlinal axis only the northwestern flank of the anticline is preserved. This flank includes the outcrops northwest of the Calderwood window where beds dip steeply to the north or are overturned, with tops facing north.

The northern limb of the anticline can be seen best along the Little Tennessee River. North and west of Chilhowee Dam, beds dip gently, forming an open fold near Tallassee, west of which steepening dips can be observed in scattered outcrops north of the river. To the east of the dam a conglomeratic bed, visible

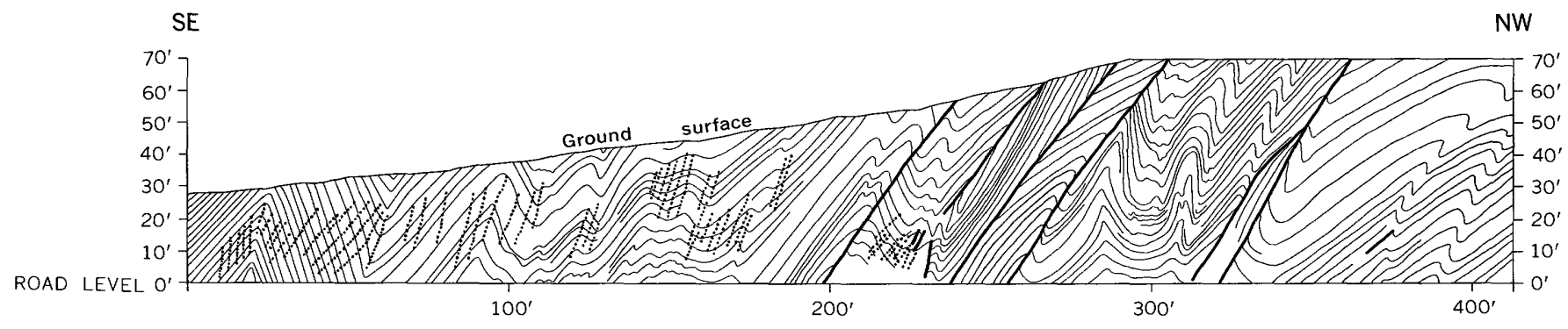

Figdre 16.-Geologic sketch of folds in the Wilhite Formation, Tennessee Highway 73, southwest bank of the Little River, northwest of the mouth of Davis Branch. Heavy lines, reverse faults; light lines, bedding; dashed lines, slaty cleavage. 
at low water, crosses the river, displaying a $65^{\circ}$ change of dip between opposite banks. To the east the structure of the siltstone is more regular, with prevailing north-facing beds, dipping steeply or overturned, but with intricate minor folding (fig. $4 A$ ).

Folds throughout this belt are shear folds that have pervasive axial-plane slaty cleavage. Many cleavage surfaces mark small offsets, and thickness of beds measured along cleavage is more consistent than thickness measured normal to bedding at various points in the folds. Most of the cleavage strikes N. $10^{\circ}-40^{\circ} \mathrm{E}$., and dips $15^{\circ}-50^{\circ} \mathrm{SE}$. To the southwest, however, for about 1.5 miles to the north of the Calderwood window, the direction is more variable, and gentle dips northwest and southwest are common. Folds that have axial planes and cleavage dipping about $10^{\circ} \mathrm{NW}$. are exposed on the west side of U.S. Highway 129 about 500 feet south of its departure from the flood plain of the Little Tennessee River (fig. 14D); graded beds in these folds indicate that progressively younger beds lie to the northwest. Because these gentle northwest dips of cleavage and axial planes of folds are confined to the northwestern margin of the Calderwood window in this area, and northwest-dipping cleavage is found along the northwestern margins of Tuckaleechee and Cades Cove windows, the dips are interpreted to have resulted from northward rotation of the upper plate of the Great Smoky fault. According to this interpretation, the angle between the fault surface and cleavage of the upper plate has remained constant over the arch described by the fault (fig. 17).

Southwest of the Calderwood window the structure resumes its regular southeast asymmetry. Near the Great Smoky fault, shearing is intense, but 500 feet away from it cleavage and bedding strike northeast and dip southeast. Sandstone beds exposed in several cuts along U.S. Highway 129 are discontinuous, and are discordant with the surrounding siltstone, suggesting large-scale boudinage. This disruption was probably associated with either the Great Smoky fault below, the Rabbit Creek fault above, or both.

The Capshaw Branch fault divides the rocks between the Miller Cove and Rabbit Creek faults into halves, separating the main body of the Wilhite For-

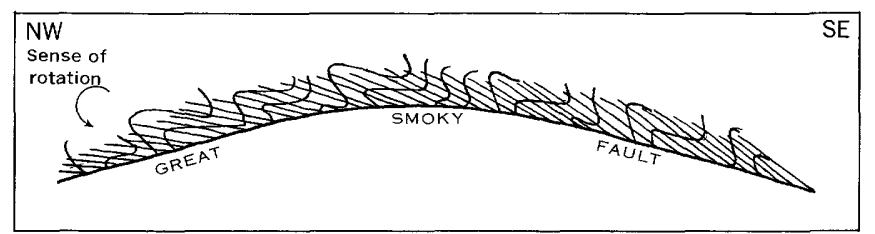

FIGURE 17.-Section showing idealized relations between arched surface of the Great Smoky fault, slaty cleavage, and bedding in the upper plate. mation on the northwest from the thick conglomeratic unit on the southeast (pls. 2, 3). Throughout most of its course the fault is clearly marked by a lithologic contrast between the gray "iron-banded" siltstones and argillites of the main body of the Wilhite Formation of the lower plate, and the thick conglomeratic units with associated dark argillites of the upper plate. In parts of its course the fault also follows fairly straight topographic lineaments, but in other parts it departs widely from them.

The main trace of the Capshaw Branch fault extends southwestward through the block between the Miller Cove and Rabbit Creek faults for about 19 miles, from a point 3 miles northeast of the Little River to within a mile of the Little Tennessee River (pl. 2), passing into more complex structures at each end, described below. The trace can be located closely on Tennessee Highway 73 on the southwest side of the Little River, where the siltstones on the northwest adjoin conglomeratic rock and dark argillite on the southeast at the mouth of Davis Branch (pl. 3). For 2 miles southwest of the Little River the fault follows a topographic lineament; beyond Blair Branch it extends northwestward around the ridges on each side of Hesse Creek, as though its dip had changed from steep to nearly horizontal. Farther southwest, past Abrams and Panther Creeks (pl. 2), the fault is on the northwest slope of a line of ridges formed of conglomeratic rocks of the upper plate. Its dip apparently is again steeper to the southeast.

Toward the northeast end of the Capshaw Branch fault, near the Little River and beyond, it apparently forms a shallow syncline, so that siltstones of the lower plate emerge on both sides of conglomeratic rocks of the upper plate, which terminate in a blunt apex near the eastern edge of the report area (pl. 3). The southeastern emergence of the fault is most clearly shown at Kinzel Springs on the Little River, where it is well exposed in a bluff on the northeastern side, about 600 feet northwest of the old highway bridge across the river. Here it dips $30^{\circ} \mathrm{NW}$, with beds above and below nearly parallel to it. Northeastward from here to the apex of the conglomeratic rocks, its course is less certain and for some distance must lie in argillaceous rocks, with only subtle differences between those inferred to be in the upper and lower plates. Southwest of the Little River the southeastern emergence of the Capshaw Branch fault is traceable for about 2 miles, to a point where it is seemingly overridden by the Cades Sandstone along the Rabbit Creek fault.

Toward the southwest, the Capshaw Branch fault and the conglomeratic rocks of its upper plate fail to 
reach the Little Tennessee River or the Calderwood window. Instead, they are apparently cut off by a later more steeply dipping reverse fault and repeated to the east beyond a triangular area of Wilhite Formation siltstone. East of the triangular area the trace of the fault is southward, and in this direction both the fault and the conglomeratic rocks above it terminate against the Rabbit Creek fault. In this segment the fault is parallel to cleavage in the overridden siltstone and dips about $35^{\circ}$ eastward.

In most of the rocks of the upper plate of the Capshaw Branch fault, tops of the beds are to the northwest, so that the beds dip mainly northwestward at low to steep angles, or are overturned southeastward. Complications occur toward the northeast, however, where the high-angle Carr Creek fault splits the thrust plate nearly in half (pl. 3). This relation is best shown near the Little River, especially on the western side along Tennessee Highway 73, where the Carr Creek fault is indicated by juxtaposed rock units, and in part by a topographic lineament. The fault repeats thick mappable units of conglomeratic sandstone and dark argillite, but the attitudes of cleavage in the argillite units on the two sides are significantly different. On the northwest side, cleavage and axial planes of folds strike northeastward and dip $30^{\circ}-45^{\circ}$ southeastward, as they do regionally through the foothills of the Great Smoky Mountains. On the southeast side, however, cleavage dips from $25^{\circ} \mathrm{NW}$. to $5^{\circ}$ SE. in strata which dip mainly northwestward. The implication that these strata are overturned is belied by their sedimentary structures. More likely, the rocks with aberrant cleavage were rotated, as they were elsewhere on the northeastern margin of the windows.

The Carr Creek fault, which lies within conglomeratic rocks southwest of the Little River is not certainly identifiable, but its extent for a mile or so from the river is suggested by a prominent linear valley (pl. 3). Much farther southwest, along Panther Creek, cleavage in argillaceous rocks for 3,500 feet northwest of the Rabbit Creek fault is aberrant, lying horizontal or dipping as much as $45^{\circ} \mathrm{NW}$. In the remainder of the belt to the northwest, cleavage dips regularly southeastward. Along Abrams Creek, however, between Panther Creek and the Little River, all cleavage dips southeastward throughout the belt.

The Capshaw Branch fault is poorly understood. Little information is available through most of its length where only its northwestern trace is exposed, but at its northeastern end it resembles a klippe of a gently dipping undulatory thrust fault. Its stratigraphic displacement is unknown because of the uncertainty of the original relations of the rocks on its opposite sides. As already mentioned (p. D22), the rocks on its upper plate may be either younger or older than those of the lower plate, and speculations concerning tangential displacement thus have little substance. The position of the Capshaw Branch fault in the relative chronology is also in doubt, although it certainly cuts folds of the lower plate and is cut by the Carr Creek and probably the Happy Hollow faults. The Capshaw Branch could be an older fault formed elsewhere to the southeast and carried forward by the Great Smoky fault. The Capshaw Branch and Great Smoky faults seem to be closely related; they may have developed simultaneously, the Capshaw Branch bringing rocks from high in the overriding plate into the trough northwest of the structural high of the windows.

The eastern edge of the map area contains the western termination of the Happy Hollow fault. This fault brings Shields and Licklog Formations over the Wilhite Formation along a southeast-dipping surface for many miles to the northeast. Possibly the Capshaw Branch and Happy Hollow are different parts of the same fault, but where they are closest, and could be connected by projecting an arch for a few hundred feet over Carr Creek, the rocks of the upper plate of each are different. Furthermore, at one place where they appear to emerge on the same slope, an arch connecting them would have an improbably short radius of curvature. Thus, the Happy Hollow fault probably cut the Capshaw Branch fault and is therefore younger.

\section{RABBIT CREEK FAULT}

The abrupt northwestern boundary of the Cades Sandstone is here designated the Rabbit Creek fault. Its trace extends for about 15 miles northeastward from the Little Tennessee River to the west end of Tuckaleechee Cove where it bends sharply southeastward and terminates against the Great Smoky fault a short distance east of the report area. Through most of its course the Wilhite Formation forms the footwall of the Rabbit Creek fault, but east of Tuckaleechee Cove the Metcalf Phyllite forms the footwall.

The great contrast between the rocks brought together along this fault indicates that it is a major feature, but as it lies entirely within formations of the Ocoee Series whose stratigraphic relations are uncertain, the amount of stratigraphic displacement is uncertain. If the Rabbit Creek fault is analogous with the Oconaluftee fault to the southeast and with the Greenbrier fault farther east (King, 1964; Hadley and Goldsmith, 1963), its displacement would be measured in miles, and the rocks of its upper plate would all be equivalent to or younger than the rocks of its lower 
plate; the fault also would be largely premetamorphic in age, but it was probably reactivated at the time of the Great Smoky fault.

At the southwestern edge of the report area the Rabbit Creek fault was located closely at the top and bottom of bluffs on the east side of the Little Tennessee River. Here it dips $65^{\circ} \mathrm{SE}$, and the conglomeratic sandstone of the Cades is faulted over conglomerate and siltstone of the Wilhite. Complex structure in the upthrown block near the fault is indicated by nearly flat but overturned beds in the quarry or river level and by beds that dip steeply southeast in normal order higher up along U.S. Highway 129.

Traced northeastward, the Rabbit Creek fault lies along the break in slope between steep hillsides underlain by the Cades on the southeast and even-crested spurs to the northwest; footwall rocks are shattered lenticular fault slivers of conglomeratic rock enveloped in intensely deformed siltstone. The strike of the Rabbit Creek fault swings abruptly to the north at Maynard Creek where conglomerate of the Wilhite Formation appears in the footwall. For about 12 miles northeast of Maynard Creek the trace of the Rabbit Creek fault follows a straight topographic depression. The hanging wall contains large amounts of dark argillite and siltstone, whereas the footwall is predominantly conglomeratic rocks of the Wilhite Formation. On the slopes north of Maynard Creek pebbles in the Wilhite are flattened to disks which define southeast-dipping foliation. Elsewhere along this segment, rocks exposed near the fault show little evidence of localized disruption, although the topographic lineament was probably carved in a zone of weakness. The fault was identified within narrow limits in several stream valleys, such as Abrams Creek (pl. 2) where it dips $30^{\circ}-60^{\circ} \mathrm{SE}$.

In the Kinzel Springs quadrangle (pl. 3) the Rabbit Creek fault cuts across several structural units, and dark slaty siltstone intervenes between the fault and the more common sandstone of the Cades.

The long northeast-trending segment of the Rabbit Creek fault falls along the projection of the Carr Creek fault. At the turn of the Rabbit Creek fault in the vicinity of Ace Gap, the southeastern emergence of the Capshaw Branch fault is overridden, as is the contact between siltstone and conglomerate of the Wilhite Formation. Southeastward from the turn the Rabbit Creek fault is nearly flat and closely follows the contours of the steep hillsides. Fine-grained rocks of the Cades of the hanging wall persist above the fault for about a mile to the southeast of the turn. On Powell Ridge, a little beyond, at the boundary of the Great Smoky Mountains National Park, the sum- mit of a small knoll is littered with float of Cades Sandstone; the surrounding lower ground contains float of chips of brown-weathered Wilhite siltstone. This knoll is a klippe of the Rabbit Creek fault, confirming low dips of the fault in this area.

The Rabbit Creek and Great Smoky faults merge at the west end of Rich Mountain, and the Wilhite Formation between them terminates abruptly. For about a mile to the southwest only the Great Smoky fault occurs, but the Rabbit Creek reappears above the Great Smoky north of the Rich Mountain Fire Tower, in Water Hollow, and on the south slopes of Whiteoak Sink where it overrides phyllite and sandstone of the Metcalf. The Rabbit Creek fault through this segment dips very gently, as shown by the parallelism of its trace with the topographic contours.

The Rabbit Creek fault is thus a major discontinuity in the present map area, along which the Cades Sandstone was thrust over the Metcalf and Wilhite. Although it is probably largely premetamorphic in age, it cuts or is cut off by younger faults, and its present configuration is due to these.

\section{ROCKS BETWEEN RABBIT CREEK AND OCONALUFTEE FAULTS}

The large structural block between the Rabbit Creek and Oconaluftee faults is formed of Cades Sandstone and Metcalf Phyllite. The Cades dominates the part of the block west and northwest of Cades Cove, and the Metcalf the part east and southeast of it. The two are repeated by faulting in a small area southwest of the cove, where two narrow belts of Metcalf taper southwestward, and a narrow intervening belt of Cades tapers northeastward. Within the Cades Sandstone, determination of tops of beds was a valuable aid in the interpretation of the structure. Tops of beds are indicated by graded bedding in its sandy layers and by relation of cleavage to bedding in its argillaceous layers (Shrock, 1948, p. 437). The Metcalf Phyllite does not afford comparable information, as its bedding is either obliterated by cleavage, or where it is visible, it either parallels the cleavage or diverges from it at small angles.

In most of the Cades Sandstone, tops of beds face northwest, but in many places the beds are overturned and dip southeastward. In the westernmost exposures in the report area (pl. 2), along the Little Tennessee River south of Calderwood, bedding is nearly flat, but is shown by graded bedding to be inverted. Farther northeast along Panther Creek, beds face southeastward for the first half-mile northwest of the Oconaluftee fault, but face northwestward beyond, where they are generally steeply overturned. On Rabbit 
Creek the beds dip southeast for about $11 / 2$ miles southeast of the Rabbit Creek fault, apparently in normal order. Along Abrams Creek, beds again mostly face northwestward, and many of them are overturned. At Abrams Falls on the northwest the gently dipping sandstone is apparently in normal order, but between here and Cades Cove, wherever tops could be determined, the beds are overturned. Some beds near the cove $\operatorname{dip} 30^{\circ} \mathrm{NW}$, but they have been rotated $210^{\circ}$. Along Hesse Creek (pl. 3) most beds are overturned, except in a short segment northeast of Short Mountain where they dip northwest. Southwest of Tuckaleechee Cove and south of Whiteoak Sink the beds dip gently, but their tops could not be determined.

In the part of the Cades just described, most of the coarse sandstone beds are strongly lineated, the lineation trending southeastward, mostly down the dip of the cleavage. Quartz grains are drawn into ribbons, some elongated as much as 10 times their median dimension, the feldspar grains being somewhat less deformed. Nevertheless, original differences in grain sizes are preserved, despite the deformation, so that grading of the beds is still visible.

Northwest-facing beds in the Cades continue southeastward to the two segments of its contact with the Metcalf just northeast and southwest of Cades Cove (pl. 2). In both segments the contact dips generally southeastward parallel to the bedding and is sharp and cleancut, without gradation. A typical exposure of the contact, on Mill Creek just southwest of Cades Cove, has been described (p. D14). At the western end of the segment northeast of Cades Cove the contact is folded into a syncline, but farther east along Rich Mountain it dips steeply to gently southward. This segment of the contact terminates eastward half a mile beyond the report area, where both it and the Cades on its north side terminate against the southeastern segment of the Rabbit Creek fault (King, 1964). The nature of the contact between the Cades and Metcalf in the two segments is undetermined. The authors have mapped it as a sedimentary contact (pl. 2), with Cades in sequence above Metcalf, but there may have been much differential movement along it, or there may have been faulting.

Southwest of Cades Cove, the narrow wedge of Cades which tapers northeastward into the Metcalf has a different structure from the main body. Here beds dip southeastward, as they do widely elsewhere; but graded bedding in many places indicates that tops of the beds face southeastward, in the opposite direction from those in the main body. The Cades wedge is apparently separated from the Metcalf wedge on the northwest by a high-angle fault, which, judging from a faint topographic lineament, seems to continue southwestward into the Cades beyond the end of the Metcalf. The change from southeast-facing to northwest-facing beds in the Cades along Panther Creek, noted above, may lie on its extension. The contact of the Cades in the wedge with the Metcalf on the southeast is more like the contact in the two segments just northeast and southwest of Cades Cove, and has likewise been mapped as a sedimentary contact (pl. 2). However, beds in the Cades face southeastward toward the Metcalf, so that stratigraphic relations would be the opposite of those in the other two segments. The contact may be faulted, as it is followed throughout by a pronounced topographic lineament.

The Metcalf Phyllite, which forms most of the eastern part of the structural block between the Rabbit Creek and Oconaluftee faults, is an incompetent unit whose rocks are pervasively cleaved and in places as schistose as rocks of higher metamorphic grade. The cleavage has in turn been cut by fracture cleavage, chevron folds of small amplitude, and by weaker crenulations.

The attitudes of cleavage of the Metcalf vary widely, but within small areas they are fairly constant. Cleavage is most nearly horizontal between Cades and Tuckaleechee Coves south of the outcrop of the Cades Sandstone, but strikes are variable, those nearest the Great Smoky fault being nearly parallel to it. South of Cades Cove the cleavage is more regular, generally parallel to bedding, striking about N. $50^{\circ}$ E., and dipping $40^{\circ}-50^{\circ} \mathrm{SE}$. By contrast, the axial planes of the chevron folds generally strike northward and are nearly vertical. Limbs of the chevron folds vary in steepness and symmetry, diverging at angles of $30^{\circ}-$ $90^{\circ}$. Their amplitude is generally small, ranging from an inch or less to several inches, but some appear to be much larger.

Third- and fourth-order crenulations are subordinate features and lack a discernible pattern. Their limbs join at small angles, their amplitudes do not exceed half an inch, and their axial planes are weakly defined.

The Cades Sandstone in the block between the Rabbit Creek and Oconaluftee faults resembles structurally and stratigraphically other bodies of sandstone in the foothills of the Great Smoky Mountains farther east, notably on Cove Mountain (King, 1964) and Webb Mountain (Hamilton, 1961, p. A15-A18). As is true of the Cades Sandstone, bedding in these rocks generally faces northward, and the sandstone on Webb Mountain overlies the Snowbird Group (Pigeon Siltstone) on the south just as the Cades Sandstone is inferred to overlie the Snowbird Group (Metcalf Phyllite). 
Like the Cades, the sandstone bodies farther east are thrust northward over other rocks of the foothill area, but those to the east are thrust only over the Snowbird Group and are not in contact with the Walden Creek Group. There the Snowbird Group is thrust over the Walden Creek Group along another fault line farther north, the Dunn Creek fault and its analogue, the Line Springs fault. In the present report area the Cades is thrust over both the Snowbird Group and Walden Creek Group in different segments of the Rabbit Creek fault. Perhaps the Rabbit Creek fault contains elements of both thrusts, which to the east are independent and areally separated features.

Various lines of evidence indicate that both sets of thrusts farther east formed early in the tectonic development of the region (Hamilton, 1961, p. A40-A42; King, 1964). The writers infer that at least some of the movement on the Rabbit Creek fault occurred at the time of the Great Smoky thrusting, because it branches from the Great Smoky and Carr Creek faults. If the Rabbit Creek fault is related to the two sets of thrusts farther east, there must have been earlier as well as later movements along it. If this inference is valid, the ancestral Rabbit Creek fault was reactivated at the time of the Great Smoky thrusting, when its forward edge was deflected upward where it impinged on the competent conglomeratic rocks on the upper plate of the Capshaw Branch fault.

The rotation of the Wilhite Formation north of the Tuckaleechee Cove and Calderwood windows, which is indicated by aberrant attitudes of cleavage, may be related to the strong overturn of the Cades Sandstone north of the Cades Cove window. Cleavage dips within a mile of the long northeast-trending segment of the Rabbit Creek fault are also more gentle than most in the area, suggesting that the Carr Creek fault followed the Rabbit Creek in this segment.

\section{OCONALUFTEE FAULT}

Within the report area the Great Smoky Group is separated from the other rocks of the Ocoee Series on the north by a marked discontinuity correlated with the Oconaluftee fault, typically developed along the Oconaluftee River farther east in the Great Smoky Mountains (Hadley and Goldsmith, 1963). In the report area the upper plate of the Oconaluftee fault is formed of Elkmont Sandstone, which in the east overrides Metcalf Phyllite and in the west, Cades Sandstone.

In the easternmost segment of the fault in the report area, from Crib Gap to Cobb Ridge, the fault is on the slopes of mountain spurs that overlook Cades Cove (pl. 2; fig. 13), where the indentation of its trace in in- tervening valleys indicates a dip of about $45^{\circ} \mathrm{SE}$. On the east side of Cobb Ridge, where the trace of the fault turns southward, Elkmont Sandstone and Metcalf Phyllite close to the fault are exposed in waterfalls of a small creek, but they show no unusual fracturing or shearing. The overriding Elkmont strikes northward, rather than northeastward as elsewhere. The overridden Metcalf Phyllite is gray rather than greenish, and its foliation is deformed by several sets of wrinkles, characteristic of the phyllite south of Cades Cove.

Between Cobb Ridge and Pine Ridge, across the drainages of Mill Creek and Forge Creek, the fault has a markedly sinuous trace because of gentle dip. East of Forge Creek it probably dips about $30^{\circ} \mathrm{SE}$., but to the west it is nearly flat. West of Pine Ridge the outcrop belt of overridden Metcalf Phyllite narrows and pinches out near the gap at Hannah Mountain, where the Elkmont is juxtaposed against the Cades Sandstone.

Near the gap at Hannah Mountain the Cades in several roadside exposures near the fault is intensely shattered. The Elkmont is poorly exposed near the fault, but in a few outcrops its sandstones are sheared and its argillaceous layers crumpled. Such localized deformation of the Cades and Elkmont near the fault may account for the pronounced topographic sag which follows its trace from Hannah Mountain southwestward to the Little Tennessee River. Through much of this segment the fault lies in creek valleys or in low intervening saddles, and is inferred to dip about $45^{\circ}$ SE. On U.S. Highway 129 near the west edge of the report area, fine-grained rocks of the Elkmont are exposed in cuts just south of the fault and are intensely deformed; the Cades Sandstone to the north has weathered to saprolite and the structure is obscure.

Interpretation of the Oconaluftee fault cannot be made on the basis of the segment in the report area, but requires consideration of the structure farther east in the Great Smoky Mountains. East of the report area the northern boundary of the Great Smoky Group is the Greenbrier fault, a low-angle thrust of large displacement which formed early in the tectonic development of the region. The rocks of both the upper and lower plates of the Greenbrier fault are traversed by a complex of variously trending high-angle faults, which displace the Greenbrier fault and its upper plate (King, 1964; Hadley and Goldsmith, 1963).

The southernmost of the high-angle faults, or Oconaluftee, lies wholly in the Great Smoky Group, or upper plate of the Greenbrier fault; along the Oconaluftee River to the southeast it trends west-northwest, curv- 
ing farther west into a west-southwest course. It is a transcurrent fault with a right-lateral strike-slip displacement which increases westward to as much as several miles. A short distance east of the present report area, another major high-angle fault, of eastnortheast trend, the Gatlinburg, converges westward with the Oconaluftee; its most prominent component of displacement is dip-slip, but it may also have a component of right-lateral strike-slip displacement. West of the convergence of the Gatlinburg with the Oconaluftee, a single major fault of the high-angle fault complex remains; this fault enters the report area from the east.

This single major fault is here correlated with the Oconaluftee fault. It is suggested that this changes from a high-angle transcurrent fault on the east to a low-angle thrust fault on the west, resulted in northwestward movement of the rocks on the west as a thrust block. This interpretation is compatible with the observed strike-slip displacement in the segment to the east, where the fault is transverse to the strike of the rocks. Similar relations have been described elsewhere in Tennessee (Stearns, 1954, p. 40-42) and in northern Italy (Sitter, 1956, p. 159).

The thrust segment of the Oconaluftee fault within the report area closely resembles the presumably older Greenbrier fault farther east, as on both faults the Great Smoky Group of the upper plate has moved along a gently dipping surface over the Snowbird Group and other rocks of the lower plate. The Greenbrier fault is of such magnitude where last preserved to the east that it very likely extends farther west. It is here suggested that the segment of the Oconaluftee fault in the report area represents a reactivation of the westward extension of the Greenbrier fault. Within the report area, the true Greenbrier fault has probably been buried beneath the Oconaluftee thrust sheet.

\section{ROCKS ABOVE OCONALUFTEE FAULT}

Structures of the thick-bedded and structurally competent Elkmont Sandstone above the Oconaluftee fault appear simple and regular, with prevailing southeasterly dips and few overturned or north-facing beds. However, these rocks were not so much studied as those to the north during the present investigations.

Exposures along U.S. Highway 129 between the Oconaluftee fault and the State line at Deals Gap display several reversals of dip and some open folds, suggesting that the apparent structural regularity seen in more scattered exposures farther east may be illusory. East of Hannah Mountain the Elkmont dips $30^{\circ}-50^{\circ}$ SE., and strikes generally more northerly than the Oconaluftee fault, so that toward the east, progres- sively younger beds abut against the fault.

Even the most massive sandstone beds show southeast-dipping foliation due to oriented micas and elongated quartz grains. Where sandstones contain concretions, as near Deals Gap, their long axes are parallel to the elongation of quartz grains down the dip of cleavage and are at least $11 / 2$ times as long as the other axes, apparently reflecting the order of magnitude of deformation.

\section{INTERPRETIVE SUMMARY RECONSTRUCTION OF OCOEE BASIN OF SEDIMENTATION}

In the foregoing pages the formations and structures of the Ocoee Series in the western part of the Great Smoky Mountains have been described. It remains to synthesize, in so far as possible, the original distribution of the sedimentary rocks. Geologic relations throughout the Great Smoky Mountains and adjacent areas must be considered in such a synthesis, because critical relations have been determined in several other places.

Superposition of the Great Smoky Group above the Snowbird Group was established by Hadley and Goldsmith (1963; King and others, 1958, p. 954) in the eastern part of the mountains. They found (Hadley and Goldsmith, 1963, p. B35) that south of the Greenbrier fault the Longarm Quartzite, and in some places the Roaring Fork Sandstone of the Snowbird Group is stratigraphically overlain by the Thunderhead Sandstone of the Great Smoky Group. To the north, however, the Greenbrier fault emerges along the contact between these groups. Through the eastern Great Smoky Mountains the maximum thickness of the Great Smoky Group is south of that of the Snowbird Group. The coarse-grained sandstones of Webb Mountain and Big Ridge (Hamilton, 1961, p. A15-A18) appear to be tongues of Great Smoky type within the Snowbird where the Snowbird is thickest, suggesting that the Snowbird and Great Smoky Groups are at least in part contemporaneous.

Direct evidence in support of this hypothesis is lacking in the present area. Beds of distinctive graded sandstone like that of the Cades, about 100 feet thick, are interbedded in the Metcalf in the Wear Cove quadrangle (King, 1964, p. 26), confirming the close relations between these formations. The Metcalf is interpreted to underlie the Cades through most of the present map area, but stratigraphic relations appear to be reversed in the short and structurally isolated fault block southwest of Cades Cove; the Cades, therefore, seems to be both underlain and overlain by Metcalf.

Relations of the Cades to the Elkmont are less certain. In eastern areas, Hamilton $(1961$, p. A18) corre- 
lated the rocks of Webb Mountain and Big Ridge with the Rich Butt Sandstone. Petrographic similarities are closer, however, between the rocks of Webb Mountain and Big Ridge and the Cades. Rocks very much like the Cades occur in turn in the upper plate of the Oconaluftee fault block at the western edge of this report area, where several hundred feet of sandstone just above the fault contain no blue quartz but abundant granitic fragments, and are similar to the Cades in composition but more like the Elkmont in sorting characteristics. Projection of strikes of the Great Smoky Group indicates that these westernmost rocks are the oldest exposed in the thrust block, which suggests that the oldest rocks above the Oconaluftee fault approach the stratigraphic level of rocks of the lower plate toward the west. Stratigraphic progression thus appears to be downward from the Elkmont into the Cades, and the Cades in turn appears to interfinger northwestward into the Metcalf. Two great faults here-the Rabbit Creek (before its postulated reactivation by the Great Smoky) and the Oconalufteehave analogous features. Along the Rabbit Creek the Cades moved northwestward and has been injected into the area of fine-grained rocks on a surface which may approximate the lower boundary of the original tongue. The Oconaluftee fault cuts across footwall beds, isolating the Cades from the main body of coarsegrained rocks, leaving a gap of unknown thickness which may decrease toward the west.

Relations between the Snowbird and Walden Creek Groups are more uncertain. Both groups contain great thicknesses of siltstone which are superficially alike, but in the eastern and central Great Smoky Mountains, various distinctive features of one are not repeated in the other on opposite sides of the intervening Dunn Creek or Line Springs faults. In the western Great Smoky Mountains the two groups are separated by more complex structures, the Tuckaleechee Cove window toward the east, and the Rabbit Creek fault elsewhere. Stratigraphic relations between the two groups must be determined outside the Great Smoky Mountains.

Little geologic study has been made west of the Little Tennessee River. No rocks comparable to the Metcalf Phyllite are known to crop out west of the present area; the Cades certainly extends beyond the Little Tennessee River, but its extent and lateral variations there remain to be determined.

Northeast of the Great Smoky Mountains, Oriel (1950, p. 23-27) classed rocks that frame the Hot Springs window as Sandsuck and Snowbird Formations, with the Sandsuck the younger; a similar succession was mapped in the nearby Del Rio district
(Ferguson, 1951). The relative positions of the two units in the Great Smoky Mountains is largely based on these observations to the northeast, although the identification of the rocks in the two areas has not yet been confirmed in detail.

If the Walden Creek Group originally succeeded the Snowbird Group, their most closely related exposed parts would be the lowest formation of the Walden Creek Group, the Licklog Formation (King and others, 1958, p. 962), and the highest of the Snowbird in the same area, probably the Pigeon Siltstone. The Licklog is a dark siltstone with interbedded sandstone and quartz-pebble conglomerate, different from the uniform greenish siltstones of most of the Pigeon. Darkcolored siltstone inferred to be the highest beds of the Snowbird Group in the central Great Smoky Mountains (King, 1964, p. 24) are more similar to the Lick$\log$ and lend support to this assumption.

That the Snowbird Group lies against the Walden Creek Group for many miles in the foothills suggests that these groups were somehow originally related. The faults that separate them, probably of an earlier generation than the Great Smoky fault, dip moderately to steeply and cut across folds that affect both groups. By analogy with similar structures in the Paleozoic rocks to the northwest, displacement was from southeast to northwest, bringing older rocks over younger, so that the Snowbird Group originally underlay the Walden Creek Group.

Determination of the relations just discussed is one of the largest unsolved problems of the Great Smoky Mountains. The stratigraphic position of the largest part of the Ocoee Series is thus left undetermined, as only the Walden Creek Group has known relations with well-dated rocks.

The Sandsuck Formation of the Walden Creek Group underlies the Chilhowee Group on Chilhowee Mountain with probable stratigraphic conformity. The Miller Cove fault intervenes between the Sandsuck and Wilhite Formations in the present area, but stratigraphic conformity of the Wilhite beneath the Sandsuck was suggested by Hamilton (1961, p. A26) in the Richardson Cove-Jones Cove area farther east.

Nevertheless, only a small segment of the Sandsuck is preserved in the same structural block with the Chilhowee Group, and, except in this structural block and in small fault slivers derived from it, no rocks of the Chilhowee Group are preserved. In the report area it is therefore impossible to demonstrate the downdip extent of either the Sandsuck or the Chilhowee Group southeast of the Miller Cove fault. The Chilhowee Group here may have been part of a widespread sheet comparable to that in northeasternmost Tennessee 
and adjacent North Carolina where it is exposed in several successive fault blocks (King and Ferguson, 1960, p. 32-45) and in the Grandfather Mountain window (Keith, 1903; Bryant and Reed, 1960, p. 4; 1962, p. 178). The absence of the Chilhowee Group and the Sandsuck Formation from the area southeast of the Miller Cove fault is probably due to the large displacement of that fault; but it is possible instead that great distance separated most of the rocks of the Walden Creek Group from those of the Chilhowee Mountain block before faulting.

The discussion above has indicated some of the difficulties of reconstructing the original sedimentary relations of the Ocoee Series, but a very hypothetical reconstruction can be made (fig. 18).

Correlation of the Shady Dolomite with the Murphy Marble in the Murphy syncline southeast of the Ocoee belt is the datum for this reconstruction. This correlation was first suggested by Keith (1907a, p. 11), later upheld by Hurst (1955, p. 72), and accords well with the results of the present investigations (King and others, 1958, p. 965).

Based on facts and inferences already discussed, the Walden Creek Group underlies the Chilhowee Group at the northwestern edge of the reconstructed section, underlain in turn by a thinning wedge of the Snowbird Group. At the southeastern edge the Nantahala Slate is underlain by the Great Smoky Group, which in turn is underlain by the Cades Sandstone and the Snowbird Group. The Snowbird here thins southeastward as it is replaced by the Cades. Basement rocks underlie the Snowbird in the southeastern part of the Great Smoky Mountains (Hadley and Goldsmith 1963, p. B27). The combined Greenbrier and Oconaluftee faults cut across beds of the Great Smoky Group at a small angle. At a lower level a large segment of the Rabbit Creek fault follows the base of the Cades Sandstone, emerging from the basement in the manner that has been suggested for the Greenbrier fault farther east (Hadley and Goldsmith, 1963, p. B79-B80). Movement along the Rabbit Creek fault thus telescoped parts of the Cades Sandstone with the Snowbird, and parallel movement along the Oconaluftee telescoped parts of the Great Smoky with the Cades and Snowbird.

The faults northwest of Oconaluftee and Rabbit Creeks are different, as they superimpose older rocks over younger. The correlations used imply that the Walden Creek and Great Smoky Groups intergraded southeast of the Dunn Creek and Line Springs faults, but that the upraised rocks containing these critical relations have been removed by erosion. The Miller Cove fault, farther northwest, brings older rocks against younger, and its stratigraphic displacement is better established. The Capshaw Branch fault is omitted as it is confined to the Walden Creek Group and offers no serious obstacles to reconstruction of the major stratigraphic relations.

The footwall of the Great Smoky fault seems to have followed lubricant shales of the overridden block. This great fault appears to postdate the metamorphism and much of the folding and faulting of the rocks of the Ocoee Series. Presumably more of the Ocoee Series and related rocks shown on figure 18 are

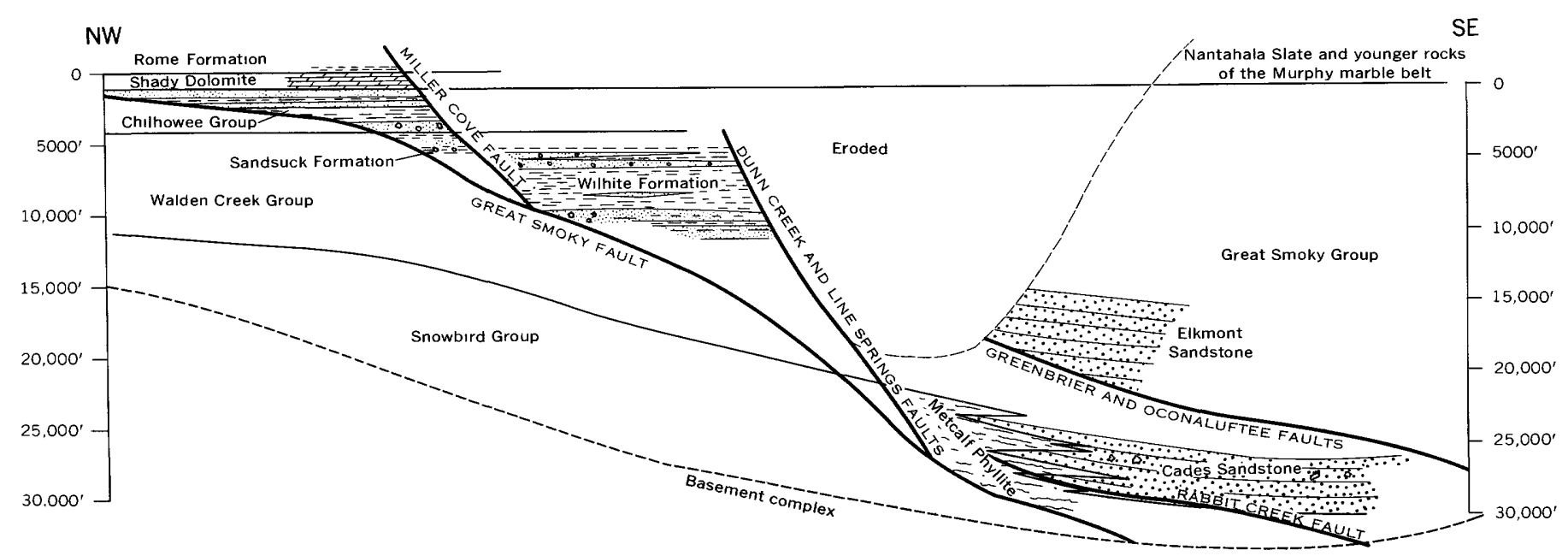

Figdre 18.-Restored section showing relative positions inferred for the major units of the Ocoee Series and related rocks and the positions of faults that dismembered them. Lithologic patterns indicate parts exposed in the western Great Smoky Mountains. Width of basin before deformation unknown, probably more than 30 miles.

$762-9000-65-6$ 
buried beneath the Great Smoky thrust sheet than are exposed in the thrust sheet itself.

Relative dimension of the basin in which the Ocoee Series was deposited will be better understood when more is learned of the region beyond the Great Smoky Mountains. Both the Snowbird and Walden Creek Groups thin northeastward along the strike and have not been identified beyond the Nolichucky River (Rodgers, 1953, p. 28, pl. 5). Northwest of the Great Smoky Mountains, no rocks older than the Rome Formation are exposed; in a deep drill hole in central Kentucky (Brown, 1951, p. 176), only 650 feet of undated strata intervenes between the Nolichucky Shale (Upper Cambrian) and dacitic basement rocks. It is apparent that the older sedimentary rocks thin northwestward, but the manner of the thinning is unknown.

Even less certain are the southeastern limits of Ocoee sedimentation. Rocks of probable Ocoee age occur within the Grandfather Mountain window (Bryant and Reed, 1960, p. 4; 1962, p. 178). Geologic maps of North Carolina east of the Great Smoky Mountains (King, 1955, map; Stuckey, 1958) show metasedimentary rocks of uncertain age at many places across the width of the Blue Ridge and Piedmont provinces, and at least some of these are probably correlative with the Ocoee Series.

Southwest of the Little Tennessee River, reconnaissance observations by the writers in the northeastern part of the Haw Knob quadrangle suggest that relations between different parts of the Ocoee Series can be studied profitably here. Southeast of the outcrop belt of the Walden Creek Group, along Citico Creek and on Salt Spring Mountain, dark-gray thickbedded sandstones with blue quartz are like the Elkmont but have abundant large rounded quartz pebbles similar to those in coarse layers of the Walden Creek Group. Structural and stratigraphic relations between these rocks and those of the present area are unknown, but they might be transitional between the Great Smoky and Walden Creek Groups.

\section{SEDIMENTATION OF OCOEE SERIES}

FLKMONT AND CADES SANDSTONES

Southeastward replacement of the Snowbird by the Cades shown on figure 18, and the same kind of relations between the Snowbird and the Rich Butt Sandstone on the east (King and others, 1958, p. 956) suggest that the source for these coarse-grained rocks had an eastern component.

The Cades and the Elkmont are alike in essential features, although details of their structures and minor petrographic differences permit distinction. Graded bedding prevails in both, and this, like their composition, suggests deposition from turbidity currents
(Kuenen and Migliorini, 1950). Kuenen (1953, p. 1060) listed features that he considered to indicate deposition from turbidity currents on "gentle slopes or on level basin floors":

1. Extreme regularity of bedding.

2. Absence of true slump structures.

3. Pelagic deep-water beds between the graded beds.

4. Grading upward in each bed to very fine sediment.

5. Thin graded beds of fine grain.

6. Absence of current ripple mark.

7. Supply from varying directions.

All these criteria, except the seventh which cannot be tested, are applicable to the Cades and Elkmont Sandstones.

1. Bedding is largely continuous across individual exposures, without noticeable pinching, swelling, or lensing out of beds within the limits of observation (fig. $3 C$ ).

2. Convolute bedding or other slump structures were not seen in either formation.

3. The dark slate and siltstone, although not denionstrably pelagic as is similar rock with pelagic fossils in younger formations, have a high sulfide content and fine and parallel laminations that indicate their deposition in a reducing environment beneath local wave base.

4. Most of the various types of graded bedding diagrammed by Kuenen (1953, p. 1049) can be found in the Cades and Elkmont. Flow markings are rare, but fragments of dark slate and siltstone included with terrigenous debris, and incompletely graded beds in many places, indicate that from place to place turbidity currents eroded as well as deposited material. Furrows that might be flow markings were seen at the base of sandstone beds at five places in the Thunderhead Sandstone along the highway south of Gatlinburg; all trend southeast.

5. Graded beds range from a few inches to 3 feet thick, but are mostly about 1 foot thick. Sand grains are most abundant within the range of $1-5 \mathrm{~mm}$; coarser gravels are rare, although the Cades Formation contains boulders as much as 3 feet in diameter.

6. Current ripples were not seen either at the tops of beds or within beds.

The composition and structure of rocks such as the Cades and the Elkmont have been interpreted to indicate deposition by turbidity currents in tectonically unstable environments by several recent studies, summarized by Pettijohn (1957, p. 312-314). The min- 
eralogy of the sandstones and their rare pebbles of granite indicate derivation from a granitic or gneissic terrain. That chemical weathering was incomplete is shown by the abundance of feldspar particles and by the occurrence of apatite in the heavy mineral suite. Much weathering is nevertheless suggested by the scarcity of rock fragments and the few heavy mineral species preserved. The preponderance of albite and microcline in the feldspars may also be interpreted as the result of advanced chemical weathering, for these species are the least susceptible of the feldspars to chemical disintegration (Goldich, 1938, p. 57). The bulk of the fine-grained rocks and the interstitial material of the sandstones was probably originally clay, now altered to micaceous minerals by metamorphism, further indicating weathering in the source area.

Observations of turbidity currents and of deposits formed by them point to several stages of transport (Natland and Kuenen, 1951; Heezen and Ewing, 1952; Heezen, 1956; George, 1957). Sediment is carried to the sea by streams and accumulates nearshore in relatively shallow water. Any of several causes later send these neritic accumulations sweeping bodily seaward at high speed into deeper water, eroding and thoroughly mixing them with bottom sediments over which they pass. As velocity and turbulence of the flow decrease, large and heavy particles settle out, followed by the settling out of progressively smaller and lighter particles until only the finest material remains in suspension. The fine fraction, now pelagic, settles very slowly in a reducing environment protected from oscillatory currents.

The source of the sand in the Cades and Elkmont remains unidentified. None of their heavy minerals were like those collected from basement rocks to the east (Carroll and others, 1957, p. 186), but comparison of the few samples involved in that study is inconclusive. The furrows seen in the Thunderhead indicate that currents flowed either from the northwest or the southeast, but a northwestern source is excluded if the Walden Creek Group is contemporaneous with the Great Smoky Group and the Cades.

\section{MetCALF PHYLITte}

The light color of the Metcalf Phyllite and the general lack of coarse-grained beds suggest an origin different from other parts of the Ocoee Series. Its stratigraphic relations with the other formations are ambiguous, but parts of the Metcalf appear both to overlie and underlie parts of the Cades Sandstone, and it contains at least one interbedded unit of coarse sandstone like the Cades.

Whereas the Cades and Elkmont appear to have been deposited in a reducing environment, the Metcalf probably accumulated in water with better circulation but not so deep. Most of its sandstone is fine grained and well sorted. Although none of them preserve sedimentary structures in the report area, equivalent siltstones of the Pigeon to the east are abundantly crossbedded (Hamilton, 1961, p. A7), as are the somewhat older but closely related Roaring Fork Sandstone and Longarm Quartzite (Hadley and Goldsmith, 1963, p. B30). In the reconstruction of figure 18, the Metcalf is bordered by rocks that may have been of deeper water origin. Possibly most of the Metcalf underlies the Cades, and the transition from Metcalf to Cades records the deepening of the basin.

\section{WHLFITE FORMATION}

The siltstones of the main body of the Wilhite Formation suggest a depositional environment different from that of the conglomeratic parts. The relatively good sorting of its fine-grained sandstone and the presence of iron carbonate and red and green beds indicate good circulation and an oxidizing environment (James, 1954, p. 272). The associated limestone beds also indicate deposition in relatively shallow water, and the brecciated parts suggest that these were perhaps stirred by storms.

The conglomerate and the rocks associated with it indicate greater relief and derivation from a nearby source; pyritic fine-grained beds suggest the poor circulation of deep water. The orientation of crossbedding, asymmetrical load casts, and pebble imbrication in the exposure at Kinzel Springs indicate transport from a northern quadrant. The rounding of grains and low feldspar content indicate a prolonged history between derivation of particles from bedrock and their final deposition. In the coarser grained rocks of the Wilhite Formation, the crudeness of graded bedding, the lenticular form of the conglomerate bodies, and the abundance of locally derived rock fragments suggest that these rocks are "fluxoturbidites" of Dżułyński, Książkiewicz, and Kuenen (1959, p. 114).

\section{SUMMARY}

The Ocoee Series thus appears to have formed in a trough that was perhaps parallel to present-day structural trends. In the early Ocoee (Snowbird) time, of which there is little record in the present area, relief between bordering lands and the floor of the trough was low. During this stage fine-grained sediments were spread by traction by normal water currents and deposited in an oxidizing environment.

Later, during Walden Creek and Great Smoky time, relief was greatly increased, with increasing depth of water and rising borderlands. Detrital materials were apparently fed to the trough from both of its margins. 
Turbidity currents developed on the southeast, transporting huge volumes of coarse sand tens or perhaps hundreds of miles from sites of marginal accumulation into deep water. On the northwest, where sedimentary volumes were smaller, unconsolidated debris was also transported downslope from basin margins into deeper water; slopes here were steeper, and the material was transported a shorter distance than was that on the southeastern margins.

Reduction of this relief was apparently gradual, resulting in a change towards shallow water and subdued margins, establishing the environment for deposition of the more mature rocks of the Chilhowee Group on the northwest and the Murphy Marble and related rocks on the southeast (Hurst, 1955, p. 56-58).

\section{LATER PALEOZOIC TIME}

The assumed continuity of a sheet of carbonate rocks, represented by the Shady Dolomite of the report area and by the Murphy Marble farther southeast, implies stable shelf conditions perhaps comparable to the widespread epicontinental seas of the Early Ordovician epoch. Terrigenous materials are nearly absent in the Shady Dolomite, and the margins of the basin in which it was deposited have not yet been determined, although a northwestern source of terrigenous materials is well established for the Rome Formation and rocks of later Cambrian and Early Ordovician age (Rodgers, 1953, p. 44 46; Cummings, 1960).

Upper Cambrian and Lower Ordovician carbonate rocks of the Knox Group contain little terrigenous material, but what is present in the Upper Cambrian was largely derived from the northwest (Prouty, 1948, p. 1344-1345). Gradation from dolomite in the northwest belts to limestone in the southeast also indicates a shore to the northwest (Cloud and Barnes, 1957, p. 185; Fairbridge, 1957, p. 154; Dunbar and Rodgers, 1957, p. 239-244).

Realinement of source and basin areas occurred near the beginning of Middle Ordovician time. At the base of the Middle Ordovician Series a widespread disconformity resulted from an important tectonic event (Bridge, 1955, p. 729). Southeastern outcrop belts of Middle Ordovician rocks contain great thicknesses of terrigenous rocks, compared with thinner carbonate equivalents in northwestern belts (King, 1950a, p. 661; Rodgers, 1953, p. 66; Cooper, 1956, p. 40), a pattern repeated by younger Paleozoic rocks throughout the Appalachian region.

A second disconformity in this area, between the Bays Formation of Middle Ordovician age and the Upper Devonian Chattanooga Shale is one of the largest gaps in the Paleozoic sequence in the southern Appalachians. Rocks that represent this missing in- terval in nearby belts of exposure are not notably coarser grained than those at a greater distance. During the time represented by this disconformity, uplift was not sufficient to furnish significant sediment to surrounding seas, and the present area during this long time perhaps intermittently received and lost sediments, with no net gain and little loss until latest Devonian time. The absence of a rubble zone other than the thin sandstone at the base of the Chattanooga, and the similarity between the Chattanooga Shale in this area and in large parts of eastern and central Tennessee, further indicate that no significant amounts of material accumulated on an erosion surface.

Mississippian rocks in the western Great Smoky Mountains and elsewhere in the southern and central Appalachians record continuing erosion of an eastern source area, and shallow-water marine, paludal, and deltaic sedimentation. The Mississippian record is incomplete in the present area, and no younger rocks are preserved here. Pennsylvanian rocks, however, are preserved along the northwestern edge of the Tennesse Valley (Rodgers, 1953, p. 113), and Permian rocks are known in West Virginia, Maryland, and Pennsylvania.

\section{TIME OF FOLDING, METAMORPHISM, AND FAULTING}

Time relations between different structural features of the area have already been mentioned; but few dates for specific tectonic events have been given, nor can close limits be adduced for many of them. The geometric relations of many faults and folds suggest a relative chronology, but spacing of events through time is more difficult to determine.

A radiometric age determination relevant for dating metamorphism in the report area is the 440 millionyear date from $\mathrm{K} / \mathrm{Ar}$ in biotite from metamorphosed rock of the Ocoee Series near Ducktown, Tenn. (Eckelmann and others, 1959 , p. 1760). This determination falls within the range of determinations made on paleontologically controlled material from the Middle Ordovician (Faul, 1960, p. 640), and thus serves to relate this metamorphism to the thick accumulation of terrigenous detritus of this age.

The Great Smoky fault is post-Mississippian and possibly Late Pennsylvanian or Permian in age. Related faults and associated deformation of earlier formed folds in this area and other folds and faults throughout the Appalachians attest the importance of orogeny at this general time. The age of the Appalachian Revolution, however, is open to scrutiny (Speiker, 1956, p. 1775-1779), and its climaxes may have spanned considerable time from place to place through the Appalachian chain. 
SURFICIAL GEOLOGY AND POST-PALEOZOIC HISTORY

The orogeny and end of sedimentation during the late Paleozoic marked a transition throughout the Appalachians from a constructional regimen to one of destruction. The present form of the landscape results from erosion of the bedrock complex through an immense span of geologic time which must have begun with the first pulses of orogeny. The first significant record of this destruction is contained in the wellknown Triassic basins from Massachusetts to South Carolina. Tectonic activity in the southern Appalachians was virtually concluded during Triassic time, and any subsequent crustal movements have been epeirogenic.

The oldest post-Paleozoic deposits in the present area are remnants of alluvium on uplands of the Valley and Ridge province, possibly of early Tertiary age like the bauxite and lignite deposits in comparable settings at a fow other places in the Appalachians (Neuman and Wilson, 1960). Deposits of Quaternary age are more abundant and represent material en route between bedrock outcrops and the sea. These deposits occur in many topographic settings, including at one extreme, accumulations of talus and creep mantle on mountainsides and at the other, alluvial deposits on flood plains. Distinctions between adjacent Quaternary deposits based on comparative lithology, topography, and stratigraphy, indicate some of the more recent events of geologic history.

Studies of the surficial geology during the present investigation were incidental to those of the bedrock, so that only the salient features of the relations of geology to landscape and of the post-Paleozoic history of the area are given here. Besides the writers' observations, many field data were provided by H. E. Malde, and additional information and suggestions were given by G. M. Richmond, C. S. Denny, and J. T. Hack during short visits to the area. The map of parent materials in part of the Kinzel Springs quadrangle (fig. 19) was compiled from an unpublished soils map by J. E. Elder, of the U.S. Soil Conservation Service.

The physiographic subdivisions of the area (pl. 1) each have characteristic bedrock and surficial features controlled by the relative resistance of bedrock units to weathering and erosion. Advanced chemical weathering throughout the area has produced saprolite from siliceous rock and residual accumulations of insoluble material from carbonate rock in many places.

\section{VALLEY AND RIDGE PROVINCE}

On a small and atypical part of the Valley and Ridge province is included in the area of plate 2. More than half of the province as a whole is underlain by carbonate rocks, but in the report area bedrock is alternating sandstone and shale with subordinate limestone and dolomite. The topography reflects the varying ease of erosion of individual units. The highest and most continuous ridges are supported by sandstones of the Tellico, Sevier, and Grainger Formations, and streams generally follow the calcareous shales. Units of intermediate competency support points of intermediate altitude, resulting in a close correlation between topography and lithology.

The ground surface is composed largely of residual and colluvial materials. The characteristics of weathered bedrock and saprolite were described with the various bedrock units. Rock decomposition also correlates with topographic position; steep slopes and drainageways expose most of the fresh rock, and gentle slopes and divides preserve decomposed rock. Colluvium probably covers a greater area than does residuum, and shales are commonly blanketed by fragments derived from upslope sandstone units. Some materials derived from sandstone must have been washed downslope particle by particle, but mass movement is evident on many slopes.

Roadcuts on some dip slopes of ridges supported by sandstones of the Tellico Formation show the effects of mass creep. Yellow shale saprolite is folded with axial planes parallel to the slope; the lower limb retains the original bedrock dips, and the short upper limb, consisting of segments of beds a few inches to a foot long, dips into the slope. The surface layer, several inches to more than a foot thick, is dark reddishbrown and consists of poorly sorted angular fragments of weathered sandstone and shale in a matrix of clayey sand. Such profiles resulted from bodily movement of shale saprolite and surface material. On some slopes there are also landslide scars-low hummocks with torn undercut banks a few inches to a foot in height on their upslope sides.

The effect of running water is not to be minimized, especially on steep cultivated slopes. Gullying is common, and a foot or more of soil consisting of fragments of weathered rock and saprolite has accumulated along the upslope sides of many old fences. The deepest gullys are active conduits of water and sediment, and where they do not flow directly into permanent streams, they build alluvial cones at their mouths. These cones are actively growing, and fresh material is deposited on them after hard rains.

A remnant of alluvium of possible early Tertiary age caps a small hill with an altitude of 1,420 feet a mile northwest of Sixmile (see also Neuman and Wilson, 1960). The deposit consists of about 40 feet of deep-red clay with scattered rounded cobbles of weath- 
ered quartzite, very different from the saprolite and weathered sandstone on summits of adjacent hills. Slopes on the upper part of this hill are more gentle than those of neighboring hills indicating that erosion is retarded by the clayey cap. Similar alluvium at about 1,100 feet altitude mantles limestone bedrock about a mile to the northwest. These deposits may originally have been at nearly the same altitude, but subsurface solution of the limestone has probably resulted in the lowering of the deposits laid on it.

Valley and Ridge physiography is modified by broad coalescing surficial deposits, resembling fans, derived from Chilhowee Mountain. Similar deposits mantle lower slopes adjacent to high mountains elsewhere in the area, but those on the northwestern slopes of Chilhowee Mountain are most abundant. Some also occur on its southeastern slope and on the lower slopes of Rich Mountain in Tuckaleechee Cove (fig. 19). On Chilhowee Mountain the deposits grade downslope from poorly sorted angular quartzite fragments in a sandy and silty fine-grained matrix that is probably colluvial, to a better sorted weakly stratified material in which the quartzite fragments are waterworn. In some places this merges with alluvium of the present valley bottoms. The younger of these deposits, which contains hard nearly fresh quartzite fragments in a yellow and grayish matrix, lies nearest the level of present drainage. The older deposits, which are deeply weathered, contain decomposed quartzite and a redstained matrix; these deposits cap interfluves. Presentday streams follow the borders of the fresher deposits in most places, and streambeds are mostly carved into bedrock.

The deposits on the northwest slope of Chilhowee Mountain are well shown near Montvale Springs (pl. 2; see also Blockhouse quadrangle, Neuman and Wilson, 1960). The buildings and clearings at the springs are on the younger, fresher deposits in which temporary excavations showed an unstratified jumble of disoriented angular blocks of quartzite, mostly about 6 inches in diameter, but ranging from 2 inches to 2 feet. About one-fourth of the face of the excavation consisted of these fragments; the remainder consisted of small chips of decomposed shale and yellow-brown and brownish-gray sandy and clayey matrix. The old trail to Murray Gap above the springs follows these younger deposits to a small stream at about the 1280-foot contour. Bedrock crops out in the streambed and on the adjacent 80-foot bluff to the south, where it is fresh or slightly weathered on steeper parts near its base and passes into saprolite in the gentler upper part. Above this, to about 1,500 feet on the ridge, is the older deposit of decomposed quartzite in a red matrix. Quart- zite fragments 8-12 inches in diameter are common here, with some as much as 2 feet across; matrix is mottled red and yellow, stiff and clayey in places and friable and sandy in others. Most quartzite fragments are decomposed and friable; others, not so thoroughly decomposed, are still much weathered and stained. Some boulders are friable near their margins but retain coherent stained cores. On the ground surface are quartzite boulders that appear to be a lag concentrate of these cores and other coherent fragments that remain after the removal of the fine particles.

These surficial deposits record the more recent erosion of Chilhowee Mountain. They appear to be both colluvial and alluvial in origin, derived from ledges higher on the mountain, and funneled into drainageways. Hack (1957) demonstrated the efficacy of intermittent catastrophic rainfall that occurs with a frequency of perhaps 100 years. Such recent deluges which deposited bouldery debris in drainageways have been described elsewhere in the Great Smoky Mountains (Moneymaker, 1939). The bouldery deposits along streams are of Recent age, and some are still in the process of formation, but those on the interfluves are older and are now being eroded. The older deposits cover a larger area than the active ones and were probably formed by more vigorous erosion than prevails today, perhaps during Wisconsin glaciations when the climate was more rigorous.

In many places the topographic relations of fresh and decomposed deposits indicate that they accumulated at widely separated times. Although once deposited in drainageways, the older deposits now cap ridges because they have retarded erosion, and drainage has shifted into the intervening area.

Although topographic and lithologic contrasts between the older and younger deposits are plain in some places, elsewhere deposits intermediate in composition and position suggest the possibility of a more complex history. A thorough study concentrating on these deposits will have to be made before reliable conclusions can be drawn.

Comparison of the older, decomposed deposits of the mountainsides with the remains of ancient (Tertiary?) alluvium described above indicates their distant relations. Whereas the Tertiary(?) alluvium caps a ridge at 1,400 feet above sea level, the alluvial toes of the deposits of the mountainsides about 1 mile to the southeast are about 300 feet lower. Because both deposits were formed near base levels of erosion of their time, this difference of altitude gives some measure of the lowering of the land surface during the interval that separates them. Thus, although the rate is not known but assumed to be slow, time of the magnitude that 
separates the early Tertiary from the late Pleistocene (40 million $\mathrm{yr}$ ) is reasonable for degradation of this amount.

\section{OUTLIERS OF THE VALLEY AND RIDGE PROVINCE- THE COVES}

Tuckaleechee, Cades, and Millers Coves have smooth contours and low relief and are more closely related to the Valley and Ridge physiographic province than to the highlands of the Blue Ridge province that surround them. This relation is confirmed by the surficial deposits. Tuckaleechee and Cades Coves are mantled by debris derived from adjacent mountains, similar in many respects to the surficial deposits at the southeastern margin of the Valley and Ridge province that were derived from Chilhowee Mountain. Tuckaleechee Cove also contains some alluvium similar to the Tertiary(?) alluvial deposits of the Valley and Ridge province described above, as well as accumulations of insoluble clay and chert from limestone bedrock and terrace and flood-plain deposits along the Little River.

\section{TUCKALEECHEE COVE}

Tuckaleechee Cove, the largest of the outliers, has the widest diversity of both bedrock geology and surficial deposits. A map of the surficial deposits of a part of the cove (fig. 19) was compiled from unpublished work of the U.S. Soil Conservation Service. Soil series of manuscript maps were combined to show parent materials, so that some subdivisions of this map contain only one soil series, but others contain two or more series whose parent materials are the same or are closely related.

The subdivisions can be grouped into residual, alluvial, and colluvial types. The residual soils are differentiated by the kinds of rock from which they were developed: the Ramsey Soil Series formed from noncalcareous shale, sandstone, and quartzite of the Ocoee Series, the Dandridge Soil Series from Ordovician calcareous shale, and the Dunmore and Talbott Soil Series from limestone and dolomite. The distribution of Ramsey and Dandridge soils corresponds closely with the bedrock geologic map (pl. 3), the Ramsey outlining the Great Smoky thrust plate, and the Dandridge the area of Ordovician shale. Most of the larger areas of limestone residual soils form steep rocky slopes and lack the thick accumulations of residual clay and chert of limestone areas northwest of Chilhowee Mountain.

Transported or colluvial material can be grouped into two parts on the basis of color: a red part that includes the Allen, Jefferson, Muse, and Leadvale Series and a gray part that consists of the Hayter Series. The red part appears to be older than the gray, and both appear to have formed by alluvial and colluvial processes.

The oldest deposit preserved in the cove caps the 1200-foot hill half a mile north of Townsend; it is a mixture of dark-red clay with subrounded to angular pebbles and cobbles of decomposed sandstone and blocks of dark reddish-brown iron oxide, presumably limonite. Some of the iron oxide has colloform concretionary surfaces and forms blocks as much as 2 feet across. Lack of exposures prevented determination of the structure of the deposit or its thickness. As in similar deposits northwest of Chilhowee Mountain, alluvial and residual material has probably been mixed; the alluvium may be a remnant of a Tertiary terrace.

Red weathered alluvium also forms wide terraces slightly above 1,100 feet near the Little River and is thus younger than the deposit just described. An area 1-2 miles west of Townsend is capped by thoroughly weathered alluvium that has been dissected and eroded. Stratified clay, silt, sand and gravel that lie with angular unconformity on saprolite or residuum are exposed in several places. The alluvium is red and yellowish red, the finer grained parts being darker and redder than the sandy and gravelly parts. Cobbles are well rounded with good sphericity. Most cobbles are feldspathic sandstone from the Thunderhead and Elkmont Sandstones in the headwaters of the Little River drainage basin and are largely decomposed to saprolite. A lag gravel of fragments that somehow escaped decomposition covers the ground surface. The unconformity at the base of the deposit is about 35 feet below the tops of adjacent gravel-capped hills. There are sinkholes where this terrace overlies limestone, and the deposit is being dissected not only by erosion into adjacent stream valleys but by collapse and runoff into the sinkholes. There is, however, no difference in altitude between areas underlain by shale and those underlain by limestone, as there is northwest of Chilhowee Mountain.

Red stratified alluvium also blankets most of the floor of Dry Valley. It is silt and clay with prominent lenses of gravel in which the fragments have a marked imbricate structure. These fragments are largely weathered slate and phyllite from the Metcalf Phyllite, but includes smaller amounts of sandstone from the Cades, both derived from the drainage area around the head of Dry Valley. The degree of decomposition of the deposits and the topographic setting of Dry Valley suggest that these deposits are of the same age as the terraces described above. The deposits in Dry Valley are being dissected through an underground drainage system expressed on the surface by sinkholes 


\section{D72}

GEOLOGY OF THE GREAT SMOKY MOUNTAINS, TENNESSEE AND NORTH CAROLINA
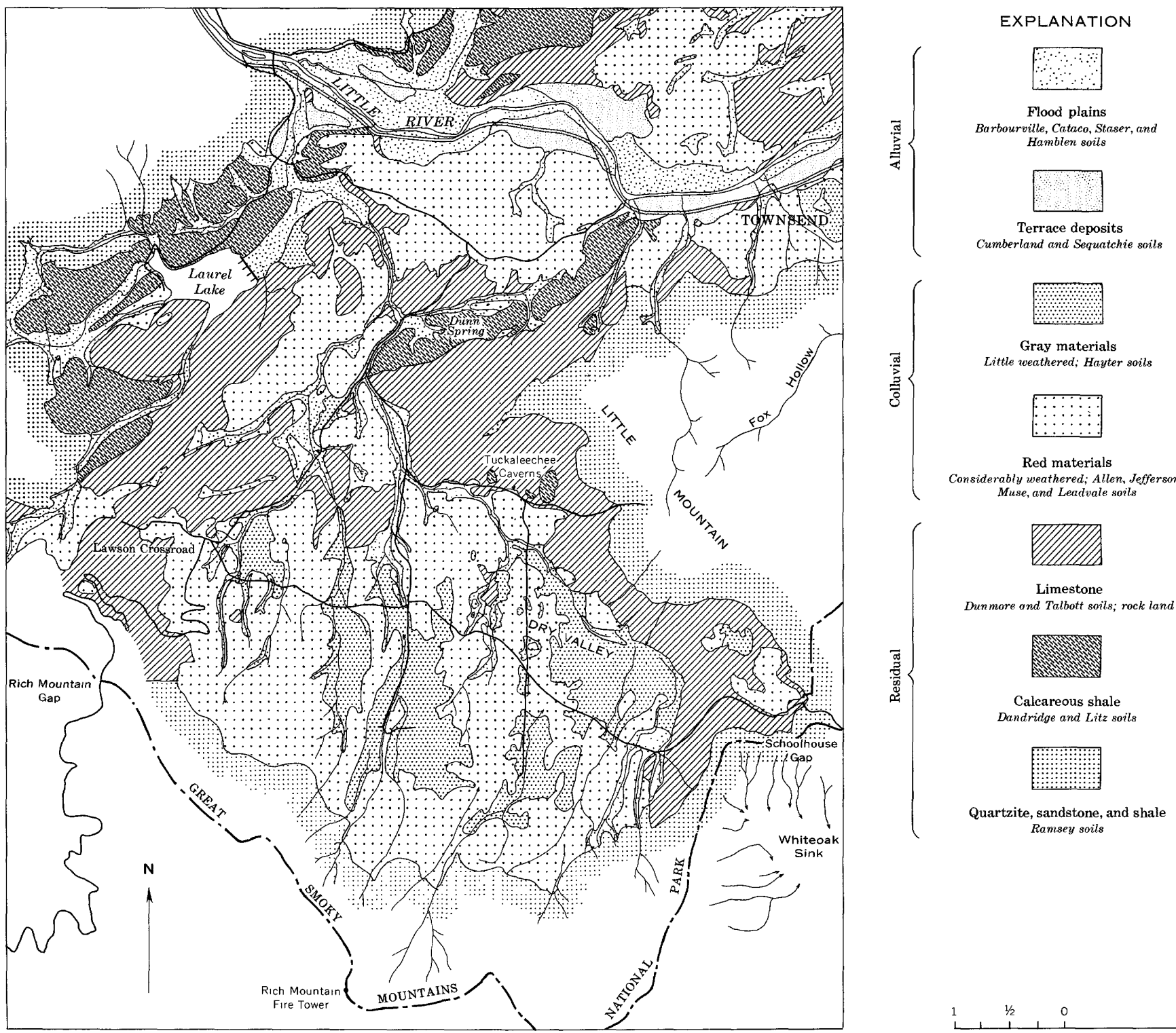

Red materials

Red materials

Muse, and Leadvale soils

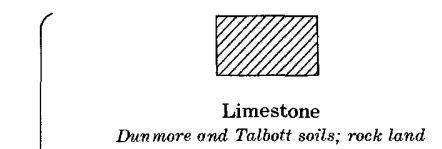

Dunmore ond Talbott soils; rock land

표료

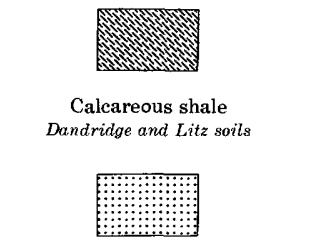

Quartzite, sandstone, and shale Ramsey soils

Figure 19.-Map of parent materials of soils in the southeastern quarter of the Kinzel Springs quadrangle. Compiled from unpublished solls map, by J. E. Elder and others, U.S. Soll Conservation Service.

that are more pronounced than those in the terraces.

The interfluves on the lower slopes of Rich Mountain are mantled with red surficial deposits that are probably largely colluvial. The deposits contain angular pieces of Cades and Metcalf that crop out on the mountain. Fragments are $1 / 2-18$ inches in size and are neither visibly sorted nor stratified, but they are randomly oriented, with oblate or tabular fragments lying at high angles to each other in a firm clay matrix. The red color is most pronounced in the matrix. Most of the sandstone fragments are thoroughly decomposed to soft yellow saprolite; some retain cohesive cores; and others, although weathered, are hard.
Phyllite fragments are weathered and yellow, but a few are soft and earthy. The red color of the matrix and the decomposition of rock fragments are uniform through the several feet of profile at several places, except for the few inches nearest the surface where they are tan and somewhat friable, perhaps due to modern organic activity and root penetration.

In the same area gray colluvium lies in broad welldefined channels apparently cut into the red deposits. These deposits extend downslope from narrow blocky valley fill at the base of waterfalls and cliffs to broad aprons on the lower slopes. The colluvium consists of relatively fresh rock debris including blocks of 
Cades Sandstone as much as 8 feet across and small sandstone and phyllite pebbles in a matrix of gray silt and sand. Rock fragments upslope, are angular, but downslope, where deposits widen, rock fragments are appreciably rounded. The colluvium appears to have been derived from the flood debris of the mountainside drainage and from the creep mantle of the slopes, channeled into drainageways, and spread downslope by both mass wasting and running water. The colluvium resembles the fresher deposits of Chilhowee Mountain in many respects, but the blocks are larger and more abundant on Rich Mountain because of difference in the bedrock geology in the two areas. Moreover, there is no permanent surface drainage on the lower slopes of Rich Mountain, and slopes covered with colluvium are not extensively gullied and eroded, out contain sinkholes from place to place.

Streams in Tuckaleechee Cove have steep gradients and are actively eroding toward the level of the Little River. The floor of Dry Valley at Tuckaleechee Caverns is 200 feet above the Little River, 2 miles away along drainage lines. Here underground drainage is active, and the stream on the floor of the caverns is apparently permanent. Rounded Ocoee rock fragments with minor amounts of chert form most of the gravel in the bed of the underground stream. The stream which plunges underground at Whiteoak Sink is presumably the same as the one in the caverns that emerges at Dunn Springs, having fallen 550 feet in 3 miles. Sinkholes undoubtedly connected with this subterranean drainage system emerge at the surface at many places in Dry Valley, and surficial deposits are eroded by collapse and wash into them. Bull Cave on the southwestern margin of the cove, with a nearly vertical shaft 500 feet deep (Gibbons and Hale, 1956), is the largest opening known in the subterranean system. More than a square mile drains into this opening, and the rotting logs that choke its entrance suggest that much debris enters the cave during periods of high runoff.

\section{CADES COVE}

Like Tuckaleechee Cove, Cades Cove has received large volumes of surficial debris from the surrounding mountains. Because no large stream passes through Cades Cove, erosion is much slower than in Tuckaleechee Cove, and the floor is 700 feet higher.

Surficial deposits in Cades Cove resemble those of Tuckaleechee Cove, but their lithology and form are somewhat different. Limestone residuum without admixtures of colluvium was seen only at a shallow roadcut in the northeast corner of the cove. Red weathered alluvium caps elongate ridges that project into the cove and stand about 125 feet above the floor.
Those on the north side have more phyllite fragments and fewer standstone boulders than their counterparts on the south, because of differences in distribution of phyllite and sandstone in the surrounding slopes. On both sides of the cove these deposits are deep red and clayey, and contain local concentrations of concretionary limonite. Overgrown pits and waste piles on one of these deposits in the southwestern part of the cove were probably made when iron was dug by early settlers. Younger less weathered coarse bouldery alluvium forms aprons at the mouths of all the streams entering the cove. Aprons of the larger streams that head in the mountains to the south are the largest; these aprons contain large boulders of fresh Elkmont Sandstone.

The broad flat floor of the cove is covered with gray and gray-brown fine-grained silt, a flood-plain deposit, parts of which are still occasionally flooded. In some places the coarse-grained alluvium of the mountain streams adjoins the finer grained flood-plain deposits at escarpments as high as 20 feet, but in other places the alluvium merges with the flood-plain deposits at the same level. The alluvium of the cove floor is probably a belt through which streams have flowed in both Recent and pre-Recent times. As the principal streams that cross the cove are at grade or even aggrading locally, erosion of surficial and bedrock material is not vigorous. Many surrounding slopes are-washed and gullied, especially on the north-central side where a small cave (Gregory Cave) indicates that solution of carbonate rocks is active. On the lower slopes and on the floor of the cove only two small sinkholes occur, indicating little recent solution. Anthony Creek, the principal stream on the cove floor, is dry in midsummer and early fall; its waters probably pass through the alluvium rather than entering into solution cavities.

\section{MULUER COVE}

Miller Cove resembles Cades Cove and Tuckaleechee Cove, but it is more elongate than the others; quartzites of Chilhowee Mountain occur on the northwest and siltstones of the Wilhite Formation on the southeast. The carbonate rocks and shale in the cove lie in sequence above the Chilhowee quartzites, so that the cove lies at the foot of a dip slope of these hard beds. Such dip slopes do not yield as abundant stony surficial deposits as those of scarp slopes (Cooper, 1944, p. 213), but yield surficial deposits in Miller Cove that differ from those of the other coves.

Jasperoid blocks and fragments, either embedded in clay or forming surface accumulations, are the most conspicuous surficial deposits in Miller Cove (see p. D32) in areas underlain by Shady Dolomite and 
Rome Formation. The jasperoid seems not to have been formed by hydrothermal alteration of the bedrock (Kesler, 1950, p. 47-50), but is associated with both the Rome and Shady as it is in northeasternmost Tennessee (King and Ferguson, 1960, p. 49). It may be related to a former epoch of weathering about the time of the formation of the older terrace deposits in which iron and manganese have accumulated (Rodgers 1948, p. 17). The origin of jasperoid may be linked to lateritization in the southeastern States (Byers and others, 1938, p. 974). During lateritization, silica accumulates in the lower parts of the profile (Carroll, 1951), and where these have been exhumed great sheets of silica are exposed (Whitehouse, 1940, p. 13; McWhae and others, 1958 , p. 122). The jasperoid in Miller Cove and perhaps elsewhere in the southern Appalachians may be remnants of such lateritic silica accumulations.

Most accumulations of jasperoid occur in areas underlain by Shady Dolomite, and these, as in Miller Cove, are lowlands covered by outwash from siliceous rocks derived from dip slopes of adjacent quartzite mountains. Lateritic decomposition of this silica-rich fill in an area underlain by carbonate rock may have satisfied the special chemical requirements for the precipitation of silica (Mohr and Van Baren, 1954, p. 381 ).

Two fans of bouldery alluvium like those of the northwest side of Chilhowee Mountain occur in Miller Cove, one at each end of the cove where the bedrock does not form dip slopes. These fan deposits are formed of hard rather than decomposed boulders in a gray-brown sandy matrix, and they merge with the alluvial fill of the cove floor without a break in slope. They are thus comparable with the younger deposits in the other areas, as are several small alluvial fans at the bases of slopes along the southeastern margin of the cove. These fans are composed largely of siltstone fragments derived from the Wilhite Formation to the southeast and have a gray-brown silty matrix.

An alluvial terrace of the Little River formed of deep-red cobbly clay is exposed in cuts of Tennessee Highway 73 near the middle of the cove, but similar deposits were not identified elsewhere. Younger alluvium near the Little River, Hesse Creek, and Reed Creek forms broad flats that are nearly continuous along the axis of the cove. The largest flat is at the southwestern end of the cove, where Shady Dolomite outcrop width is greatest, and where Hesse and Flat Creeks emerge from the mountains.

Small rapids near the mouths of Hesse and Reed Creeks indicate that their downcutting has not kept pace with that of the Little River. In Miller Cove, as in Tuckaleechee Cove, erosion of surface materials and solution of carbonate rocks is now active. The outcrop belt of Shady Dolomite is marked by a row of steepwalled sinkholes, and solution beneath alluvial fill is indicated by recently formed sinkholes in the alluvium of the Little River and at the southwestern end of the cove (Blockhouse quadrangle, Neuman and Wilson, 1960).

\section{BLUE RIDGE PROVINCE}

Many of the deposits of the Valley and Ridge province and its outliers have been derived from the adjacent highlands of the Blue Ridge province. Intermittent aggradation alternated with degradation of slopes in the low-lying areas, but no aggradation is indicated in the Blue Ridge. Saprolite occurs on ridge crests from the lower knolls up to the State line divide, the abundance of bedrock exposures depending on the composition of the rock. Slopes are largely mantled with loose, fresh, and weathered material, and stream valleys are narrow and have little alluvial fill.

Little is known of the way that this saprolite and bedrock fragments of the slopes enter the creep mantle. Uprooted trees, and pits and mounds that indicate the uprooting of trees long ago decayed, suggest a possible major mechanism of downslope transport (Denny and Goodlett 1956, p. 64). On even the steepest slopes, however, vertical trunks of standing trees more than 1 foot in diameter imply that there has been little or no mass movement and that these slopes have been stable for a long time. On the other hand, accumulations of rock debris at the base of some hills, especially those that are not undercut by streams, indicate that the creep mantle is active.

The form and composition of alluvial deposits bordering the mountain streams are governed not only by bedrock geology of the drainage basin but by local factors. The upper courses of streams that rise along the State line divide in the Elkmont Sandstone are lined with bouldery fill. Streams that rise on lower slopes in the same formation have less fill which is not as bouldery. The fill is broadest at stream intersections where main streams have been unable to remove alluvium contributed by the tributaries. Many of the now-abandoned farms in the mountains are at such intersections.

Many of the stream valleys in slaty rocks have steep sides and little alluvial fill. The most subdued topography of the foothills and the broadest alluvial fill occur in the slaty rocks of the Wilhite Formation between Happy Valley and Chilhowee and resemble Miller Cove, although the valley contains only insignificant amounts of carbonate rocks. 


\section{POST-PALEOZOIC HISTORY}

The post-Paleozoic history of the Great Smoky Mountains and the southern Appalachians is poorly known and has been constructed from a fragmentary paleontologic and geomorphic record. Plant fossils date a few surficial deposits as Paleocene or perhaps Late Cretaceous in age (Brown in Bridge, 1950, p. 194). Climates from Cretaceous through Oligocene time were probably humid and warm, but not tropical (Barghoorn, 1953, p. 244). From Oligocene time, climates cooled (Brooks, 1949, p. 382), culminating in the cold climates of the Pleistocene. Many of the deposits in the area of this study resulted from these changes.

The erosional history of the Appalachians has been related to a series of erosion surfaces or peneplains (for example, Fenneman, 1938, p. 186-194), but the existence of these features has been questioned in areas where they have been thought to have been best developed. In north-central Pennsylvania the upland surfaces are not graded to any conceivable drainage network, but are probably controlled by the resistant bedrock formations of the area (Denny, 1956, p. 4351). Resistance to denudation produced apparent erosion surfaces in southwestern Virginia where both lithology and dip of beds governed the altitude of ridges formed from them (Cooper, B.N., 1944, p. 215217). According to Denny (1956, p. 49), formation of the drainage pattern does not require preexisting peneplain surfaces, but is controlled by bedrock structure and integrated by stream capture. The controlling processes are not only stream erosion, but "the gradual lowering of the ridge tops by chemical and mechanical weathering and by mass movements that are more or less independent of downcutting by streams" (Denny, 1956, p. 44).

Hack (1957, p. 94) shares this point of view:

the regularity of the topography in the Central Appalachians and the Piedmont may simply be the result of the action of processes over a long period of time on rocks of different resistance to mechanical and chemical attack. The fact that these rocks are exposed in belts of regular thickness and attitude for great distances results in a regular topography of ridges and valleys. That the altitudes of the tops of many interstream ridges composed of similar rocks are nearly the same is only because the belts of rocks have nearly the same width and the region has undergone erosion for so long that a condition of dynamic equilibrium has been reached.

Erosion in the Appalachians may thus have been virtually continuous since deformation, guided by the tectonic framework at rates governed by climate, and thus may not have been a succession of pulses of uplift and renewed erosion.
If former erosion surfaces existed in the western Great Smoky Mountains, as many as five of them might be required to interpret the erosion history. These five surfaces correspond with rock units-one each for the Cades Sandstone, the Walden Creek Group, the Chilhowee Group, the Grainger Formation, and the Cambrian and Ordovician formations together. From a distance, each of these surfaces seems to be accordant, but in detail (pl. 2, and 1:24,000 quadrangle maps) each has a wide range of altitudes.

Each rock formation has a somewhat different topographic competency from the mountain-forming Elkmont Sandstone with its thick beds of well-knit quartzose sandstone to the lowland-making fissile calcareous shales. Even subtle features have topographic expression. Thus, although the Elkmont and Cades Sandstones are much alike in outcrop and thin section, the topography developed on the Cades is lower and more subdued than that of the Elkmont. On the other hand, the ridge tops of the more resistant beds of Middle Ordovician formations stand at about the same altitudes as the rolling upland of the Newala and Longview Formations.

Variations in structure and stratigraphy are also reflected in the topography, as along the crest of Chilhowee Mountain which is highest where the resistant Hesse Quartzite is thickest. The ridge is pierced by the Little River at the only prominent cross fault in the mountain. Summit levels on the ridges of the Clinch Sandstone northwest of the report area are more even because of regular stratigraphy and struc-. ture, although these ridges were supposed to represent the Schooley or Cumberland peneplain (Fenneman, 1938, p. 269).

The oldest deposits of the area, perhaps of early Tertiary age, are alluvial gravels that form high-level remnants in the Valley and Ridge province and the coves, and perhaps the jasperoid in Miller Cove. The composition of the old alluvial deposits implies that the streams which deposited them had gradients and source areas comparable with those of today. Their gravels could not have been transported by sluggish streams across a topography approaching peneplanation. That the gradients of these streams were steeper than modern ones is suggested by the mild climate of the early Tertiary which would promote chemical weathering and reduce the amount of fresh rock entering alluvial systems. Younger Tertiary surficial deposits have not been identified in the report area. Although paleoclimatologic data indicate progressive cooling during this time (Brooks, 1949, p. 382), contemporaneous alluvial deposits must have been small and ephemeral. 
Surficial deposits on the slopes of Chilhowee and Rich Mountains, all but the oldest terrace deposits of the Little River, and the alluvial fill of Cades Cove are probably of Pleistocene age, and probably resulted from the effects of the cold climate of that time. A striking contrast has already been noted between the relatively fresh and younger deposits largely in depressions and the older and more weathered deposits at higher altitudes. Although no fossils have been found to differentiate or date these two sets of deposits, their differences in topographic position and weathering suggest that considerable time separates their deposition. Undisturbed stands of trees on the younger deposits indicate that these deposits are not receiving yearly increments, but the large amount of fresh or little-weathered rock in them indicates that they are relatively young. These deposits are reasonably correlated with the most recent Wisconsin glaciation, but they may be reactivated by occasional catastrophic storms. The older deposits may have formed during earlier Wisconsin glaciation, in pre-Wisconsin Pleistocene time, or through an interval spanning both.

During the colder phases of Pleistocene time the eastern United States south of the ice margin was probably cooler and wetter than it is at present (Dillon, 1956 , p. 168, 170-171). Pleistocene deposits contain spruce and fir pollen near Tallahassee, Fla., and spruce trunks and cones in Louisiana. Pollen spectra from the coastal plain of North Carolina suggest that the climate there was similar to but moister than that of New York today. The southward shift of isotherms indicated by these data suggests that the higher parts of the Great Smoky Mountains stood above timberline, and the effects of these climatic changes also affected lower altitudes. During this time, ice wedging of rock from exposed ledges and runoff concentrated in spring months from thawing and melting of accumulated snow and ice were more active than now, and probably accelerated the formation of the younger surficial deposits of the area.

\section{REFERENCES CITED}

Averitt, Paul, 1941, The Early Grove gas field, Scott and Washington Counties, Virginia: Virginia Geol. Survey Bull. 56, $50 \mathrm{p}$.

Baldwin, Mark, Kellogg, C. E., and Thorp, James, 1938, Soil classification, in U.S. Dept. Agriculture, Soils and Men: U.S. Dept. Agriculture, Yearbook of Agriculture, 1938, p. 979-1001.

Barghoorn, E. S., 1953, Evidence of climatic change in the geologic record of plant life, in Shapley, Harlow, ed., Climatic change: Cambridge, Mass., Harvard Univ. Press, p. 236-248.

Becker, G. F., 1895, A reconnaissance of the gold fields of the southern Appalachians: U.S. Geol. Survey 16th Ann. Rept., pt. 3, p. 251-331.
Bridge, Josiah, 1950, Bauxite deposits of the southeastern United States, in Snyder, F. G., ed., Symposium on mineral resources of the southeastern United States: Knoxville, Tenn., Univ. Tennessee Press, p. 170-201.

— 1955, Disconformity between Lower and Middle Ordovician series at Douglas Lake, Tennessee: Geol. Soc. America Bull., v. 66, p. 725-730.

Brooks, C. E. P., 1949, Climate through the ages: New York, McGraw-Hill, 395 p.

Brown, W. H., 1953, The geology (of the Austinville district): Mining Eng., v. 5, p. 1217-1218.

Brown, W. R., 1951, Sodaclase-dacite from the California Company No. 1 A. R. Spears deep test, Lincoln County, Kentucky: Jour. Geology, v. 51, p. 175-178.

Bryant, Bruce, and Reed, J. C., Jr., 1960, Road log of the Grandfather Mountain area, North Carolina: Carolina Geol. Soc. Guidebook, 1960, 21 p.

- 1962, Structural and metamorphic history of the Grandfather Mountain area, North Carolina-A preliminary report: Am. Jour. Sci., v. 260, p. 161-180.

Burchard, E. F., 1913, The red iron ores of East Tennessee: Tennessee Geol. Survey Bull. 16, 173 p.

Butts, Charles, 1940, Geology of the Appalachian Valley of Virginia, geologic text and illustrations: Virginia Geol. Survey Bull. 52, pt. 1, 568 p.

Byers, H. G., Kellogg, C. E., Anderson, M. S., and Thorp, James, 1938, Formation of soil in U.S. Dept. Agriculture, Soils and Men: U.S. Dept. Agriculture, Yearbook of Agriculture, 1938, p. 948-978.

Campbell, M. R., 1893, Geology of the Big Stone Gap coal field: U.S. Geol. Survey Bull. 111, 106 p.

Carroll, Dorothy, 1951, Mineralogy of laterites: Australian Jour. Sci., v. 14, p. 41-42.

Carroll, Dorothy, Neuman, R. B., and Jaffe, H. W., 1957, Heavy minerals in arenaceous beds in parts of the Ocoee series, Great Smoky Mountains, Tennessee: Am. Jour. Sci., v. 255, p. 175-193.

Cattermole, J. M., 1962, Geology of the Maryville quadrangle, Tennessee: U.S. Geol. Survey Geol. Quad. Map GQ 163.

Cloud, P. E., Jr., 1948, Brachiopods from the Lower Ordovician of Texas: Harvard Coll. Mus. Comp. Zoology Bull., v. 100, p. 451-472.

Cloud, P. E., Jr., and Barnes, V. E., 1948, The Ellenburger group of central Texas: Texas Univ. Pub. 4621, 473 p.

1957, Early Ordovician seas in central Texas, in Ladd, H. S., ed., Treatise on marine ecology and paleontology, v. 2, Paleoecology: Geol. Soc. America Mem. 67, p. 163-214.

Cooper, B. N., 1944, Geology and mineral resources of the Burkes Garden quadrangle, Virginia: Virginia Geol. Survey Bull. $60,299 \mathrm{p}$.

Cooper, B. N., and Cooper, G. A., 1946, Lower Middle Ordovician stratigraphy of the Shenandoah Valley, Virginia: Geol. Soc. America Bull., v. 57, p. 35-114.

Cooper, B. N., and Prouty, C. E., 1943, Stratigraphy of the lower Middle Ordovician of Tazewell County, Virginia: Geol. Soc. America Bull., v. 54, p. 819-886.

Cooper, G. A., 1951, New brachiopods from the Lower Cambrian of Virginia: Washington Acad. Sci. Jour., v. 41, p. 4-8, 1956.

1956, Chazyan and related brachiopods: Smithsonian Misc. Colln., v. 127 (2 pts.), 1245 p.

Cummings, David, 1960, The basal Chepultepec sandstone (Cambrian-Ordovician boundary) in the Valley and Ridge province of Tennessee: Jour. Sed. Petrology, v. 30, p. 228-240. 
Currier, L. W., 1935, Zinc and lead regions of southwestern Virginia: Virginia Geol. Survey Bull. 43, $122 \mathrm{p}$.

Denny, C. S., 1956, Surficial geology and geomorphology of Potter County, Pennsylvania: U.S. Geol. Survey Prof. Paper 288, 72 p.

Denny, C. S., and Goodlett, J. C., 1956, Microrelief resulting from fallen trees, in Denny, C. S., Surficial geology and geomorphology of Potter County, Pennsylvania: U.S. Geol. Survey Prof. Paper 288, p. 59-62.

Dillon, L. S., 1956, Wisconsin climate and life zones in North America: Science, v. 123, p. 167-176.

Dunbar, C. O., and Rodgers, John, 1957, Prinicples of stratigraphy: New York, John Wiley \& Sons, 356 p.

Dźułyński, S., Ksiąźkiewicz, M., and Kuenen, P. H., 1959, Turbidites in Flysch of the Polish Carpathian Mountains: Geol. Soc. America Bull., v. 70, p. 1089-1118.

Eckelmann, F. D., Kulp, J. L., and Long, Leon, 1959, Tentative chronology of metamorphic-plutonic events in the southern Appalachians based on new $\mathrm{K} / \mathrm{A}$ and $\mathrm{Rb} / \mathrm{Sr}$ age determinations [abs.]: Geol. Soc. America Bull., v. 70, p. 1761.

Fairbridge, R. W., 1951, The dolomite question, in Soc. Econ. Paleontologists and Mineralogists, Regional aspects of carbonate deposition: Soc. Econ. Paleontologists and Mineralogists Spec. Pub. 5, p. 125-178.

Faul, Henry, 1960, Geologic time scale: Geol. Soc. America Bull., v. 71, p. 637-644.

Fenneman, N. M., 1938, Physiography of eastern United States: New York, McGraw-Hill, 714 p.

Fenton, C. L., and Fenton, M. A., 1934, Scolithus as a fossil phoronid: Pan-Am. Geologist, v. 61, p. 341-348.

Ferguson, H. W., 1951, Areal geology, in Ferguson, H. W., and Jewell, W. B., Geology and barite deposits of the Del Rio district, Cooke County, Tennessee: Tennessee Div. Geology Bull. 57, p. 9-46.

George, T. N., 1957, Sedimentary processes and structures: Sci. Prog., v. 45, p. 278-292.

Gibbons, J. H., and Hale, Daniel, 1956, Down into Bull Cave: Natl. Speleol. Soc. News, v. 14, p. 62-63.

Gilluly, James, 1960, A folded thrust in Nevada-inferences as to time relations between folding and faulting: Am. Jour. Sci., v. 258a, p. 68-79.

Glover, Lynn, 1959, Stratigraphy and uranium content of the Chattanooga shale, Alabama, Georgia, and Tennessee: U.S. Geol. Survey Bull. 1087-E, p. 133-168.

Goldich, S. S., 1938, A study in rock weathering: Jour. Geology, v. 46, p. 17-58.

Gordon, C. H., 1920, Notes on the geology of the cove areas of eastern Tennessee [abs.]: Science, new ser., v. 51, p. 492-493.

Hack, J. T.; 1957, Studies of longitudinal stream profiles in Virginia and Maryland: U.S. Geol. Survey Prof. Paper 294-B, p. 45-97.

Hadley, J. B., and Goldsmith, Richard, 1963, Geology of the eastern Great Smoky Mountains, Tennessee and North Carolina: U.S. Geol. Survey, Prof. Paper 349-B, 118 p.

Hadley, J. B., King, P. B., Neuman, R. B., and Goldsmith, Richard, 1955, Outline of the geology of the Great Smoky Mountains area, Tennessee and North Carolina, in Russell, R. J., ed., Guides to southeastern geology: New York, Geol. Soc. America, p. 390-427.

Hamilton, Warren, 1961, Geology of Richardson Cove and Jones Cove quadrangles: U.S. Geol. Survey Prof. Paper 349-A, 55 p.
Hass, W. H., 1956, Age and correlation of the Chattanooga shale and the Maury formation: U.S. Geol. Survey Prof. Paper $286,47 \mathrm{p}$.

Hayes, C. W., 1891, The overthrust faults of the southern Appalachians: Geol. Soc. America Bull., v. 2, p. 141-154.

Heezen, B. C., 1956, Corrientes de turbidez del Río Magdalena: Soc. Geog. Colombia Bol. 51-52, p. 135-143.

Heezen, B. C., and Ewing, W. M., 1952, Turbidity currents and submarine slumps, and the 1929 Grand Banks earthquake: Am. Jour. Sci., v. 250, p. 849-873.

Hurley, P. M., Cormier, R. F., Hower, John, Fairbairn, H. W., and Pinson, W. H., Jr., 1960, Reliability of glauconite for age measurement by $\mathrm{K}-\mathrm{Ar}$ and $\mathrm{Rb}-\mathrm{Sr}$ methods: Am. Assoc. Petroleum Geologists Bull., v. 44, p. 1793-1808.

Hurst, V. J., 1955, Stratigraphy, structure, and mineral resources of the Mineral Bluff quadrangle, Georgia: Georgia Geol. Survey Bull. 63, $137 \mathrm{p}$.

James, H. L., 1954, Sedimentary facies of iron-formation: Econ. Geology, v. 49, p. 235-293.

Keith, Arthur, 1892, Geology of Chilhowee Mountain in Tennessee: Philos. Soc. Washington Bull., v. 12, p. 71-88.

- 1895, Description of the Knoxville sheet: U.S. Geol. Survey, Geol. Atlas, Folio 16.

- 1896a, Description of the Loudon sheet: U.S. Geol. Survey, Geol. Atlas, Folio 25.

$1896 \mathrm{~b}$, Description of the Morristown sheet: U.S. Geol. Survey, Geol. Atlas, Folio 27.

1903, Description of the Cranberry quadrangle: U.S. Geol. Survey, Geol. Atlas, Folio 90.

- 1904, Description of the Asheville quadrangle: U.S. Geol. Survey, Geol. Atlas, Folio 116.

- 1907a, Description of the Nantahala quadrangle: U.S. Geol. Survey, Geol. Atlas, Folio 143.

1927, Great Smoky overthrust [abs.]: Geol. Soc. America Bull., v. 38, p. 154-155.

1928, Structural symmetry in North America: Geol. Soc. America Bull., v. 39, p. 321-385.

Kellberg, J. M., and Grant, L. F., 1956, Coarse conglomerates of the Middle Ordovician in the southern Appalachian Valley: Geol. Soc. America Bull., v. 67, p. 697-716.

Kesler, T. L., 1950, Geology and mineral deposits of the Cartersville district, Georgia: U.S. Geol. Survey Prof. Paper 224, $95 \mathrm{p}$.

King, P. B., 1950a, Geology of the Elkton area, Virginia: U.S. Geol. Survey Prof. Paper 230, 82 p. [1954].

1950b, Tectonic framework of southeastern United States: Am. Assoc. Petroleum Geologists Bull., v. 34, p. 635-671.

- 1955, A geologic section across the southern Appalachians: an outline of the geology in the segment in Tennessee, North Carolina and South Carolina, in Russell, R. J., ed., Guides to southeastern geology: New York, Geol. Soc. America, p. 332-373.

1964, Geology of the central Great Smoky Mountains, Tennessee: U.S. Geol. Survey Prof. Paper 349-C, 148 p.

King, P. B., and Ferguson, H. W., 1960, Geology of northeasternmost Tennessee: U.S. Geol. Survey Prof. Paper 311, 136 p.

King, P. B., Ferguson, H. W., Craig, L. C., and Rodgers, John, 1944, Geology and manganese deposits of northeastern Tennessee: Tennessee Div. Geology Bull. 52, 275 p.

King, P. B., Hadley, J. B., Neuman, R. B., and Hamilton, Warren, 1958, Stratigraphy of Ocoee series, Great Smoky Mountains, Tennessee and North Carolina: Geol. Soc. America Bull., v. 69, p. 947-966. 
Kuenen, P. H., 1953, Significant features of graded bedding: Am. Assoc. Petroleum Geologists Bull., v. 37, p. 1044-1066. 1956, The differences between sliding and turbidity flow: Deep-Sea Research, v. 3, p. 134-139.

Kuenen, P. H., and Migliorini, C. I., 1950, Turbidity currents as a cause of graded bedding: Jour. Geology, v. 58, p. 91-127.

Laurence, R. A. and Palmer, A. R., 1963, Age of the Murray Shale and Hesse Quartzite on Chilhowee Mountain, Tennessee: U.S. Geol. Survey Prof. Paper 475-C, p. C53-C54.

MacCulloch, John, 1814, Remarks on several parts of Scotland which exhibit quartz rock, and on the nature and connexions of this rock in general: Geol. Soc. London Trans., v. 2, p. $450-487$.

McWhae, J. R. H., Playford, P. E., Lindner, A. W., Glenister, B. F., and Balme, B. E., 1958, The stratigraphy of western Australia: Geol. Soc. Australia Jour., v. 4, p. 1-161.

Mohr, E. J. C., and Van Baren, F. A., 1954, Tropical soils: Amsterdam, Royal Tropical Inst., 498 p.

Moneymaker, B. C., 1939, Erosional effects of the Webb Mountain (Tennessee) cloudburst of August 5, 1938: Tennessee Acad. Sci. Jour., v. 14, p. 190-196.

Natland, M. L., and Kuenen, P. H., 1951, Sedimentary history of the Ventura basin, California, and the action of turbidity currents, in Soc. Econ. Paleontologists and Mineralogists, Turbidity currents and the transportation of coarse sediments to deep water-a symposium: Soc. Econ. Paleontologists and Mineralogists Spec. Pub. 2, p. 76-107.

Neuman, R. B., 1947, Notes on the geology of Cades Cove, Great Smoky Mountains National Park, Tennessee: Tennessee Acad. Sci. Jour., v. 22, p. 167-172.

1951, The Great Smoky fault: Am. Jour. Sci., v. 249, p. $740-754$.

- 1955, Middle Ordovician rocks of the Tellico-Sevier belt, eastern Tennessee: U.S. Geol. Survey Prof. Paper 274-F, p. 141-178.

- 1960, Geology of the Wildwood quadrangle, Tennessee: U.S. Geol. Survey Geol. Quad. Map GQ-130.

Neuman, R. B., and Palmer, A. R., 1956, Critique of Eocambrian and Infracambrian: Internat. Geol. Cong., 20th, Mexico City 1956, Symposium sobre el Sistema Cámbrico, su Paleogeografía y el Problema de su Base, v. 1, p. 427-435.

Neuman, R. B., and Wilson, Robert, 1960, Geology of the Blockhouse quadrangle, Tennessee: U.S. Geol. Survey Geol. Quad. Map GQ-131.

Oder, C. R. L., 1934, Preliminary subdivision of the Knox dolomite in east Tennessee: Jour. Geology, v. 42, p. 469-497.

Oriel, S. S., 1950, Geology and mineral resources of the Hot Springs window, Madison County, North Carolina: North Carolina Div. Mineral Resources Bull. 60, 70 p.

Pettijohn, F. J., 1957, Sedimentary rocks: 2d ed., New York, Harper \& Bros., 718 p.

Potter, P. E., and Pettijohn, F. J., 1963, Paleocurrents and basin analysis: New York, Academic Press, 296 p.

Prouty, C. E., 1946, Lower Middle Ordovician of southwest Virginia and northeast Tennessee: Am. Assoc. Petroleum Geologists Bull., v. 30, p. 1140-1190.

— 1948, Paleogeographic significance of Cambro-Ordovician sandstones of northeast Tennessee [abs.]: Geol. Soc. America Bull., v. 59, p. 1344-1345.

Resser, C. E., 1938, Cambrian system (restricted) of the southern Appalachians: Geol. Soc. America Spec. Paper 15, 140 p.
Richter, Rudolph, 1927, "Sandkorallen"-Riffe in der Nordsee: Natur u. Museum, v. 57, p. 49-62.

Rodgers, John, 1948, Geology and mineral deposits of Bumpass Cove, Unicoi and Washington Counties, Tennessee: Tennessee Div. Geology Bull. 54, 82 p.

- 1953, Geologic map of east Tennessee with explanatory text: Tennessee Div. Geology Bull. 58, pt. 2, 168 p.

Safford, J. M., 1856, A geological reconnaissance of the State of Tennessee: State Geologist 1st Bienn. Rept., 164 p. 1869, Geology of Tennessee: Nashville, $550 \mathrm{p}$.

Safford, J. M., and Killebrew, J. B., 1876, The elementary geology of Tennessee: Nashville, Tenn., 255 p.

Sanders, J. E., 1952, Mississippian Grainger formation in northeast Tennessee [abs.]: Geol. Soc. America Bull., v. 63, p. 1295.

1953, "St. Louis" limestone (Mississippian) of the southern Appalachians [abs.]: Geol. Soc. America Bull., v. 64 , p. 1536 .

Shrock, R. R., 1948, Sequence in layered rocks: New York, McGraw-Hill, $507 \mathrm{p}$.

Sitter, L. U. de, 1956, Structural geology: New York, McGrawHill, $552 \mathrm{p}$.

Snyder, F. G., 1947, The problem of the Lipalian interval: Jour. Geology, v. 55, p. 146-152.

Spieker, E. M., 1956, Mountain-building chronology and nature of geologic time scale: Am. Assoc. Petroleum Geologists Bull., v. 40, p. 1769-1815.

Stearns, R. G., 1954, The Cumberland Plateau overthrust and geology of the Crab Orchard Mountains area, Tennessee: Tennessee Div. Geology Bull. 60, 47 p.

Stose, G. W., and Schrader, F. C., 1923, Manganese deposits of east Tennessee: U.S. Geol. Survey Bull. 757, 154 p.

Stose, G. W., and Stose, A. J., 1949, Ocoee series of the southern Appalachians: Geol. Soc. America Bull., v. 60, p. 267-320.

Stuckey, J. L., 1958, Geologic map of North Carolina: North Carolina Div. Mineral Resources.

Twenhofel, W. H., and others, 1954, Correlation of the Ordovician formations of North America: Geol. Soc. America Bull., v. 65, p. 247-298.

Ulrich, E. O., 1911, Revision of the Paleozoic systems: Geol. Soc. America Bull., v. 22, p. 281-680.

__ 1929, Ordovician trilobites of the family Telephidae and concerned stratigraphic correlations: U.S. Natl. Mus. Proc., v. 26, p. 1-101 [1930].

U.S. Weather Bureau, 1954, Climatological data, Tennessee, annual summary, 1953: v. 57, no. 13.

Walcott, C. D., 1891, Correlation papers, Cambrian: U.S. Geol. Survey Bull. 81, 447 p.

Weller, J. M., and others, 1948, Correlation of the Mississippian formations of North America: Geol. Soc. America Bull., v. 59, p. 91-196.

Westergård, A. H., 1931, Diplocraterion, Monocraterion and Scolithus from the lower Cambrian of Sweden: Sveriges geol. undersökning, v. 25, p. 3-25.

Whitehouse, F. W., 1940, Studies in the late geological history of Queensland: Queensland Univ. Papers, Dept. Geology, v. 2, new ser., no. 1, 74 p.

Wilmarth, M. G., 1938, Lexicon of geologic names of the United States: U.S. Geol. Survey Bull. 896, 2396 p.

Yochelson, E. L., and Bridge, Josiah, 1957, The Lower Ordovician gastropod Ceratopea: U.S. Geol. Survey, Prof. Paper 294-H, p. 281-304. 


\section{INDEX}

[Italic page numbers indicate major references]

A

Page

Abrams Creek $\ldots . . . . . . . . . . .12,13,20,58,59,61$ Abrams Falls............................ 12, 18, 61 Ace Gap................................ 60 Acknowledgments................. 4 Alie Mountain. .

Allegheny Springs..................... 24, 26, 44, 46

Alluvium...........................

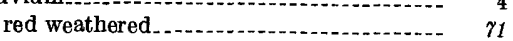
Tertiary(?) _.......... 69, 70,71

Anakeesta Formation

Analyses, chemical, Shady Dolomite....... $\quad 31$ spectrographic, Shady Dolomite.......... $\quad 30$

Anthony Creek ........ 78

Anticline, Fair Garden.....................

Anticlines.............. 45, 51, 58, 88

Appalachian Revolution, age............ 68

Austinville district in southern Virginia......

\section{B}

Bacon Bend Member of Sevier Formation .-. $\quad 38$ Bates Mountain synclinorium ............ 20, 22, 57 Bays Formation...................... $38,44,46,47,68$ fossils

Beard Cane Creek

Beard Cane Mountain.

Becker, G. F., quoted... 5

Big Ridge......... 63, 64

Big Spring Cove window............ 48

Blair Branch....... 58

Bliss Sandstone, in west Texas. ............ 26

Blockhouse quadrangle.................. 26, 27, 44

Blockhouse Shale description .............. 36

Toqua Sandstone Member. . .............. $\quad 36$

Whitesburg Limestone Member.......... $\quad \$ 5$

Blue Ridge province......................... 8,74

Boundaries, physiographic . . . .

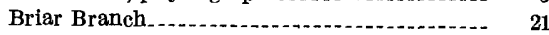

Bull Cave....

Butterfly Gap.

\section{C}

Cades Conglomerate....................... 10

Cades Cove ..... 8, 7, 8,9, 10,13,33, $84,51,61,71,78,76$

Cades Cove Mountain ................. 18

Cades Cove window

Cades Sandstone ..... 6, 7, 8, 17, 59,60,62,63, 66, 71, 75 description .............................. 10 exposed sections. . .

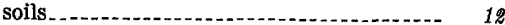
stratigraphic relations...................... 18 weathering features.

Calderwood Lake.

Calderwood window _... $5,19,33,34,47,51,58,50,62$

Cambrian rocks. . . .

Cambrian(?) rocks. . . .

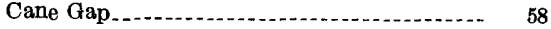

Capshaw Branch Fault_ 19, 20, 21, 57, 58, 60, 61, 62, 65

Carr Creek fault.......................... 59,62

Cartersville district in Georgia

Cedar Bluff...................................... 48

Chattanooga Shale.................... 40,45, 68 Gassaway Member, fossils.............. 41

Chilhowee Group ......... 23, 51, 52, 55, 56,64, 68, 75 $\begin{array}{ll}\text { correlation of formations....................... } & 24\end{array}$
Chilhowee Mountain .................... Ds $4,22,28,24,26,27,28,51,55,56,64,70,73$ 75,76 .

block faults

Chilhowee Post Office..................... $\quad 20$

Chilhowee Sandstone of Safford. . . ......... 23

Chilogatee Gap_...................... 24, 25, 27, 56

Chota Formation fossils............................................. 38 Citico Conglomerate......................... 14 Citico Creek

Cleavage . ............... 5, 7, 8,9,12,15,20, $58,59,61$

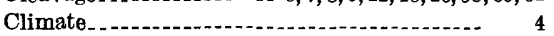

Climates, Pleistocene........................ 70,75

Clinch Sandstone $\ldots \ldots \ldots$

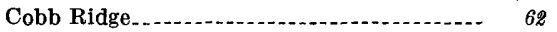

Cochran Creek...... 20,23

Cochran Formation.................... 22, 28, 55 description.............................. 24 distribution and stratigraphy _........... 24

Colluvium ......................... 4, 72

Compton Branch of Walden Creek.......... 27

Conasauga Formation................... $\quad 29$

Concretions in Elkmont Sandstone.......... $\quad 7,9$

Cove, defined . ............................. \&

Cove Mountain . .......................... 61

Coves, Valley and Ridge Province-.....-.-. $\gamma_{1}$

Crib Gap.-....... 62

landslides east of ...................... 10

Cumberland peneplain.

D

Davis Branch. . .

Deals Gap.................................. 9, 63

Del Rio district ................................. 32

Devonian System.

Dick Creek

Disconformity, at base of Middle Ordovician Series.

between Bays Formation and Chattanooga Shale

Dixon Mountain Member of Wilhite Formation ......................... 14, 22

Douglas Lake Member of Lenoir Limestone-- $\quad 35$

Drainage

Dry Valley.................. 71,78

Duncan, Helen, fossils identified by ........- 44

Dunn Creek fault. .................... 57,62,64,65

Dunn Creek fault system

Dunn Spring.

\section{$\mathrm{E}$}

Elkmont Sandstone $\ldots$. $6,11,12,17,62,68,66,71,74,75$ description location and nature of exposed sections ... soils

stratigraphic relations

weathering features.

English Mountain fault.

F

Fair Garden anticline Fall Branch.
Page

Fans, alluvial _. . . . Fault, Capshaw Branch.... 19, 20, 21, 57, 58, 60, 61, 65 Carr Creek ......................... 59,60,62 Dunn Creek......... 57, 62, 64, 65 English Mountain Gatlinburg _........................... 68 Great Smoky ............ $24,26,33,34,36,39,45,48,51,56,57,60,61$, 65,68 .

Greenbrier $\ldots$

Guess Creek

Happy Hollow . ........................ 57, 59

Line Springs_............... 52, $55,62,64,65$

Miller Cove............. 5, 19, 20, 52, 55, 56,64, 65

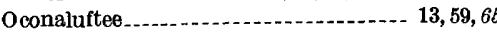

Rabbit Creek ............. 18, 52, $57,58,59,64,65$

within Mississippian rocks............... 54

Fault block, Chilhowee Mountain ........ 45 $52,55,56,64,65$

Oconaluftee

Oconaluftee
Fault blocks.

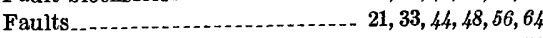

on Chilhowee Mountain.............. 54

thrust..................................... 88,45

Fieldwork......... 4

Flat Creek . .

Flats, The syncline.................. 55,56

Folds

62

Fortner Branch of Cochran Creek .......... 24

Fossils, Bays Formation ................. 39

Cades Cove

Calderwood window

Chattanooga Shale....................... 41

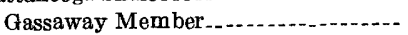

Chota Formation

Helenmode Formation.....................

Hesse Quartzite. .

Jonesboro Limestone . . . . . . .

Murray Shale. -

Nebo Quartzite.

tectonic slice north of Mount Nebo

Tellico Formation

Tuckaleechee Cove.......................

Whitesburg Limestone Member of Block-

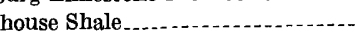

Gassaway Member of Chattanooga Shale,

fossils................. 41

Gatlinburg quadrangle................. $\quad \mathbf{7 , 9}$

Geography

human................................ 3

Geologic section, Cochran Formation........ 25 Mississippian rocks at Butterfiy Gap.-.- 42

Shady Dolomite........................... 31

Wilhite Formation....................

Glaciation, Wisconsin . .

Gordon, MacKenzie, Jr., fossils identified by .- 41 , 


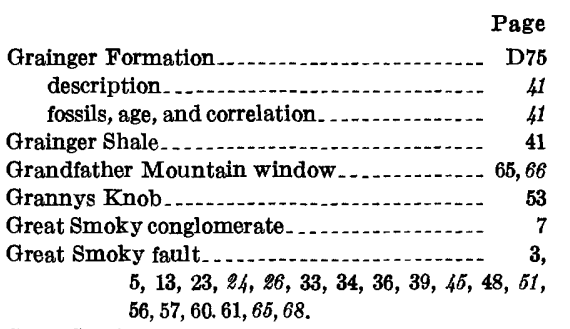

Great Smoky Group................ 6, 9, 10, 62, 68, 66 Great Smoky Mountains National Park ..... 2 Great Smoky thrust sheet............. \$9, 47, 48, 54.66 Greasy Cove Formation...............41, 45, 46, 47 description........................... 42 fossils, age, and correlation Greasy Cove and Grainger Formations, undiff-
erentiated. Greenbrier fault. Greendale syncline . . . . . . . Guess Creek fault................. $34,38,99,45,53,54$ Guess Creek fault block..................... 46

Hack, J. T., quoted......... 75 Hannah Mountain.......................... 62, 63

Happy Hollow fault ...................... 57, 59

Happy Valley

Hatcher Mountain. .............................. 22

Haw Knob quadrangle..... 66

Helenmode Formation................... 27, 28, 55 description.............................. 28 fossils...................................... 29 Helenmode Member of Erwin Formation.... 28 Hesse Creek.................... 19, 27, 55, 58, 61, 74 Hesse Quartzite.............. 24, 26, 27, 32, 65, 56, 75 ossils.

Hesse Sandstone............ 27,28

High Top............ 48

Hillsdale Limestone.......................... 44

Hiw assee Slate.................................. 14

Hot Springs window, North Carolina...... 55,64

$\mathbf{J}$

Jasperoid, in Miller Cove.............. $\$ 2, \$ \$, 55,79,75$ Jockey Creek, Green County, Tenn. ......... 34 Johns Ridge......................... 22 Jones Cove quadrangle.................. 14, 22, 57 Jonesboro Limestone ................. 39, 47, 48, 62, 54 description. ........................... 38 fossils tectonic slices.................. $47,48,61$

Keith, Arthur, quoted

Keokuk Limestone of Mississippi Valley basin...................... 42, 44

Kingsport Formation. Kinzel Branch............................. 21

Kinzel Springs on Little River. . . . . . . . . . 58,67 Kinzel Springs quadrangle.............. 12 , $20,22,31,39,44,46,56,57,60,69$

Knox Dolomite Knox Group.............................. \$8, 48, 52, 68 Knox Sandstone.......................... 29 Knox Shale.............. 29

Knoxville quadrangle.................... 10

Kykers Ferry quadrangles....... 47

\section{L}

Landslide scars................ 5 Landslides east of Crib Gap........ 10 Later Precambrian rocks. ......................

Lenoir Limestone, description ................ $\$ 5$ Douglas Lake Member. fossils.

Mosheim Member Licklog Formation. . .
Page

Licklog(?) Formation

D6, 14

Line Springs fault .......... $52,55,62,64,65$

Little Mountain..........................-. 40, 41,42

Little Pigeon River.................... 56

Little River $17,21,25,27,28,39,39,47,56,57,58,59,71,74,76$ Little Tennessee River. . . $5,13,15,19,20,23,38,39,46,56,57,58,60,64$

Little Valley Formation.................. 44 Location of area.

Longarm Quartzite..................... 9, 63, 67

Longview Dolomite.

Look Rock . .

Lower Mississippian Series................... $\quad 41$

\section{M}

Maccrady Formation of southern Virginia..- 42, 44 Mascot Dolomite

Maynard Creek...

Metcalf Bottoms on Little River........ 9

Metcalf Phyllite.......... 6, 18, 14, 51, 59, 60, 63, 67, 71 description ..................... stratigraphic relations..................... 10 weathering features..

Metainorphism, effects radiometric age determination for dating-Middleset Hollow . ........................... 17,20 Middle Ordovician rocks .................. $45,47,54$

Middle Ordovician Series..._._.......... 2, 34,68 correlation................................... 40

Middle Ordovician shales.................... 58

Mill Creek, exposure of Cades Sandstone..... 14,61

Miller Cove............... \$, 28, 29, 31, $32,38,55,71,79$

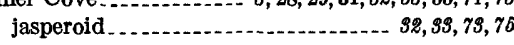

Miller Cove fault._.......... $5,19,20,52,55,56,64,65$

Minerals in, Cades Sandstone Cochran Formation..................... 24 Elmont Sandstone............ 7,67

Helemode Formation

Hesse Quartzite. . . . ...........................

metamorphic rocks. .........................

Metcalf Phyllite

Murray Shale... 27

Nebo Quartzite

Wilhite Formation. ..................... 15,17

Mint

Mississippian rocks...... 45,68

Mississippian System. . . . .

Montvale Springs . . . .

Mosheim Member of Lenoir Limestone........ $\$ 5,39$

Mount Nebo............... 26

Mount Nebo Springs....................... 26

Murphy Marble_............................ 65,68

Murphy syncline.................................. 65

Murray Branch of Walden Creek.............. 27

Murray Gap. ...... 27, 56,70

Murray Shale $\ldots \ldots \ldots, 26,28,29,55,56$ fossils

Nantahala Slate

National Park Service..........

Nebo Quartzite........................ 24, $26,56,56$ fossils.

Newman Limestone ...................... 41, 42

Nichols Branch of Walden Creek......... 25

Nichols Shale, description.

fossils

O

Ocoee basin of sedimentation, reconstruction.- $\quad 69$ Ocoee River

Ocoee Series............. $5,48,51,59,63,65$ sedimentation..................................... 66

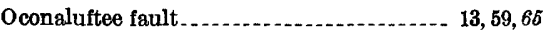

Oconaluftee fault block.
Oconaluftee River

Page

Ordovician system

Outliers of Valley and Ridge Province-the coves............................... 71

\section{P}

Paleozoic rocks Panther Creek Parson Branch

Pebbles in, Cochran Formation conglomerate of Wilhite Formation........ 15 conglomerate of Cades Formation........ 12 Sandsuck Formation

Pennsylvanian rocks. . . .

Permian rocks....... 68

Pigeon River.

Pigeon Siltston

Pigeon Slate

Pine Ridge..

Pleistocene deposits

Powell Ridge

Precipitation at Gatlinburg, Tenn

Price Formation of southern Virginia........

\section{Q}

Quarries, slate...

Quarry, east side of Little River exposures of Elkmont Sandstone......... northeast of Ninemile Creek.

Quaternary deposits.

\section{$\mathbf{R}$}

Rabbit Creek fault $\ldots \ldots \ldots \ldots . . . . .18,52,57,58,59,64,65$

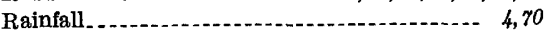
Reconstruction of Ocoee basin of sedimentation.

Red Bank

Reed Creek.

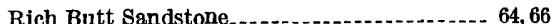

Rich Mountain

Rich Mountain Gap.

Richardson Cove quadrangle........... 14, 22, 57

Roaring Fork Sandstone.............. 9, 10, 63,67

Rocky Branch

Rome Formation......... 24, 29, $32,65,56,66,68,74$

Rose, H. J., analyst.

\section{$\mathbf{s}$}

Safford, J. M., quoted.

St. Louis Limestone.

Salt Spring Mountain. $5,6,14,22,24,25,29,56,64$

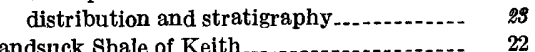
Saprolite Schooley peneplain Sedimentation of Ocoee Series................ $\quad 66$ Sevier Formation, Bacon Bend Member....- $\quad 38$ description. ............................. 98 fossils Shady Dolomite....... 29, $55,56,6 \tilde{}, 68,73$ description ............................... 29 stratigraphic relations and age........... 32 Shields Formation.................... 14, 15, 22, 59 Short Mountain............. 40,41, 45 Sinkholes, Cades Cove..................... 51 Miller Cove......... 65, 74 Tuckaleechee Cove Slaty knobs, Valley and Ridge province...... $s$ Snowbird Formation. .................... 9,64 Snowbird Group............. 6, 9, 10, 52, 61,62,68,64 Sohn, I. G., fossils identified by.

Soils Cades Cove....

Elkmont Sandstone

Rome Formation

Tellico Formation.

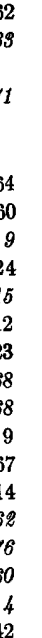




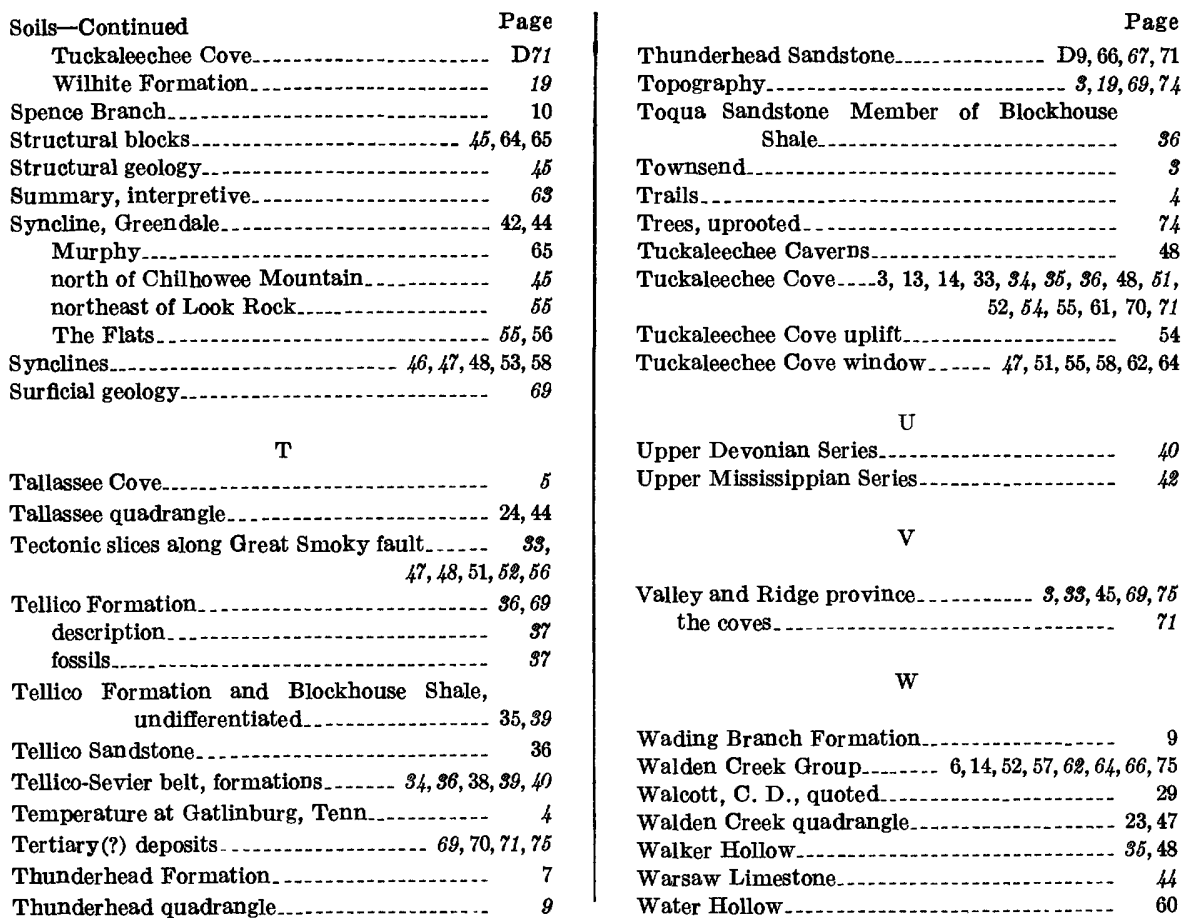

Wear Cove Wear Cove quadrangle......- 9, 10, 14, 20,47, 48, 57,63 Wear Cove window .................. 48, 51, 52,55 Webb Mountain ........................ 14,61, 63,64

Westergård, A. H., quoted_............ 27 Whistling Gap................................ 10,14 Whiteoak Sink .................. 9, 48, 51, 60, 61, 73 Whitesburg Limestone Member of Blockhouse

fossils

$$
\text { Shale. }
$$

Wilhite Creek

Wilhite Formation... $5,6,12,14,51,56,57,59,62,64$,

$67,73,74$

conglomeratic units.

15,56

Dixon Mountain Member.............. 14, 15, 22

exposed sections.......................... 19

lithologic features....................... 15

soils ............ 19

stratigraphic relations..................... 28

weathering features....................... 19

Yellow Breeches Member................ 15, 22

Wilhite Slate

Windows, Great Smoky thrust sheet. ..... $\$ \$, 47,5 \$$

Wisconsin glaciation

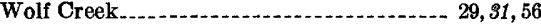

Wolfpen Gap.................. 26

$\mathbf{Y}$

Yellow Breeches Member of Wilhite Forma-

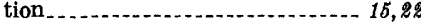



UNITED STATES DEPARTMENT OF THE INTERIOR

STEWART L. UDALL, Secretary

GEOLOGIGAL SURVEY

Thomas B. Nolan, Director

Library of Congress catalog-card No. GS 65-292 


\section{CONTENTS}

[The letters in parentheses preceding the titles designate separately paged and published chapters]

(A) Geology of the Richardson Cove and Jones Cove quadrangles, Tennessee, by Warren Hamilton.

(B) Geology of the eastern Great Smoky Mountains, North Carolina and Tennessee, by Jarvis B. Hadley and Richard GoIdsmith.

(C) Geology of the central Great Smoky Mountains, Tennessee, by Philip B. King.

(D) Geology of the western Great Smoky Mountains, Tennessee, by Robert B. Neuman and Willis H. Nelson. 



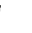

$$
\text { , }
$$

